\title{
A CERÂMICA GREGA DO CASTELO DE CASTRO MARIM
}

Ana Margarida Arruda

Daniela Ferreira

Elisa de Sousa

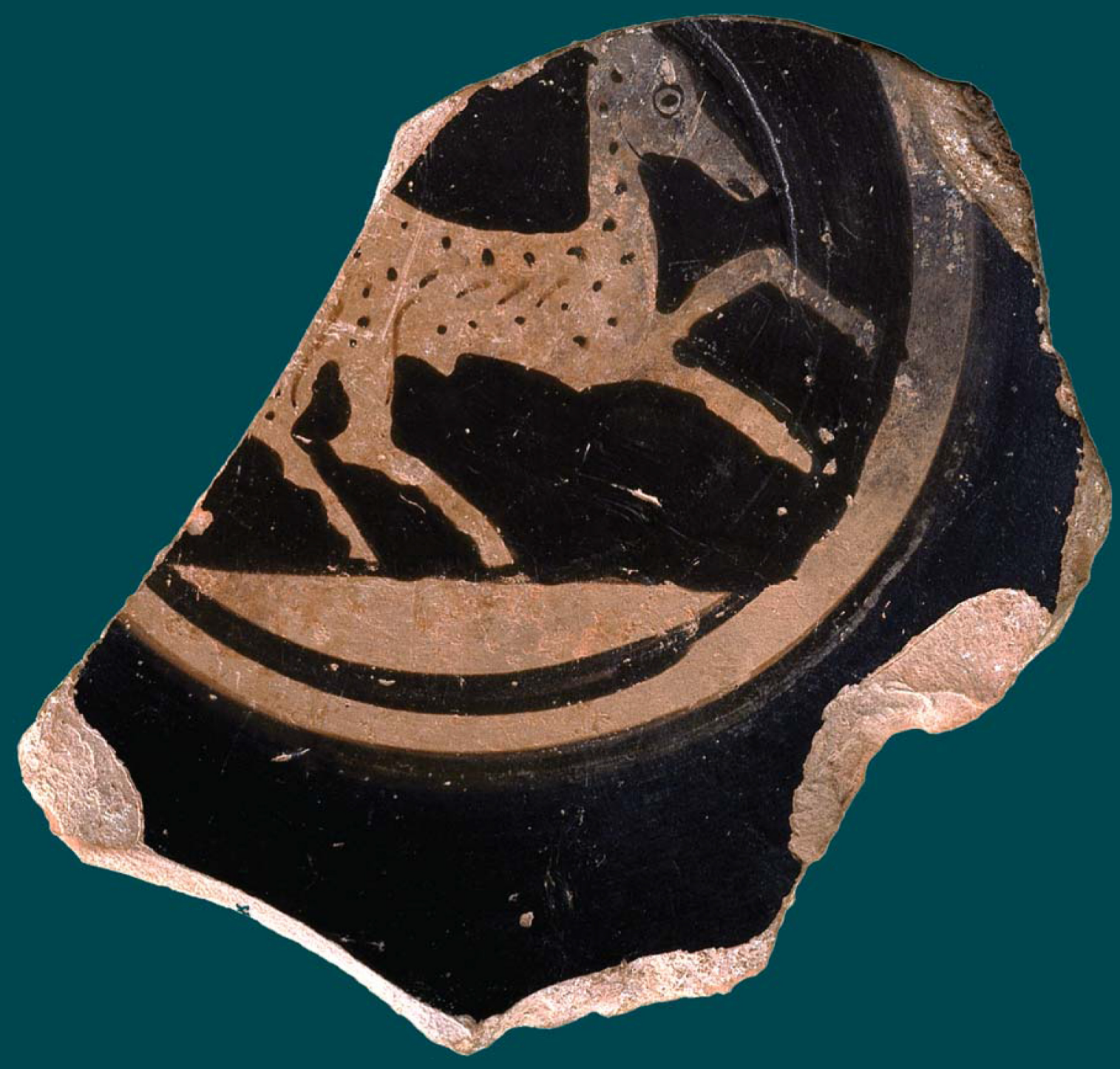

CENTRO DE ARQUEOLOGIA DA UNIVERSIDADE DE LISBOA 


\section{estudos \&
memórias}

\section{A CERÂMICA GREGA \\ DO CASTELO DE CASTRO MARIM}

Ana Margarida Arruda

Daniela Ferreira

Elisa de Sousa 
U

LISBOA

UNIVERSIDADE

DE LISBOA
FACULDADE

DELETRAS

UNIVERSIDADE

DE LISBOA

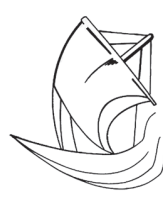

FC DA UNIVERSIDADE DE LISBOA

\section{uniarq}

Fundação para a Ciência e a Tecnologia

CENTRO DE ARQUEOLOGIA

\section{estudos \& memórias}

Série de publicações da UNIARQ

(Centro de Arqueologia da Universidade de Lisboa)

Direcção e orientação gráfica: Ana Catarina Sousa

Série fundada por Victor S. Gonçalves

13.

ARRUDA, A. M. - FERREIRA, D. - SOUSA, E. (2020) - A cerâmica grega do Castelo de Castro Marim. Estudos e memórias 13. Lisboa: UNIARQ/FL-UL. 112 p.

Capa e contracapa: André Pereira.

Capa: Kylix de figuras vermelhas do século $V$ a.n.e. Fotografia de Victor S. Gonçalves. Contracapa: Trabalhos de campo no Castelo de Castro Marim. Fotografia de Ana Margarida Arruda.

Paginação e composição: Elisa de Sousa

Impressão: AGIR Produções Gráficas

500 exemplares

ISBN: 978-989-99146-8-1 / Depósito legal:

Copyright $\odot$, 2020, os autores.

Toda e qualquer reprodução de texto e imagens é interdita, sem a expressa autorização do autor, nos termos da lei vigente, nomeadamente o DL 63/85, de 14 de Março, com as alterações subsequentes.

Lisboa, 2020.

Esta publicação é financiada por fundos nacionais através da FCT - Fundação para a Ciência e a Tecnologia, I.P., no âmbito do projecto UIDB/00698/2020.

\section{Volumes anteriores de esta série:}

LEISNER, G. e LEISNER, V. (1985) - Antas do Concelho de Reguengos de Monsaraz. Estudos e Memórias, 1. Lisboa: CAH/UNIARQ/INIC. $321 \mathrm{p}$.

GONÇALVES, V. S. (1989) - Megalitismo e metalurgia no Alto Algarve Oriental. Uma aproximação integrada. 2 volumes.Estudos e Memórias, 2. Lisboa: CAH/UNIARQ/ INIC. $566+333 \mathrm{p}$.

VIEGAS, C. (2011) - A ocupação romana do Algarve. Estudo do povoamento e economia do Algarve central e oriental no período romano. Estudos e Memórias, 3. Lisboa: UNIARQ. $670 \mathrm{p}$.

QUARESMA, J. C. (2012) - Economia antiga a partir de um centro de consumo lusitano. Terra sigillata e cerâmica de cozinha em Chãos Salgados (Miróbriga). Estudos e Memórias, 4. Lisboa: UNIARQ. 488 p.

ARRUDA, A. M. (ed.) (2013) - Fenícios e Púnicos, por terra e mar. Actas do VI Congresso Internacional de Estudos Fenícios e Púnicos. 1. Estudos e Memórias, 5. Lisboa: UNIARQ. 506 p.

ARRUDA, A. M. (ed.) (2014) - Fenícios e Púnicos, por terra e mar. Actas do VI Congresso Internacional de Estudos Fenícios e Púnicos. 2. Estudos e Memórias, 6. Lisboa: UNIARQ. 698 p.

SOUSA, E. (2014) - A ocupação pré-romana da foz do estuário do Tejo. Estudos e Memórias, 7. Lisboa: UNIARQ. $449 \mathrm{p}$.

GONÇALVES, V. S. - DINIZ, M. - SOUSA, A. C. (eds.) (2015) - $5^{\circ}$ Congresso do Neolítico Peninsular. Actas. Estudos e Memórias, 8. Lisboa: UNIARQ. $621 \mathrm{p}$.

SOUSA, A. C. - CARVALHO, A. - VIEGAS, C. (eds.) (2016) Terra e Água. Escolher sementes, invocar a Deusa. Estudos em Homenagem a Victor S. Gonçalves. Estudos e Memórias, 9. Lisboa: UNIARQ. 623 p.

GONÇALVES, V. S. (ed.) (2017) - Sinos e Taças, Junto ao Oceano e mais longe. Aspectos da presença campaniforme na Península Ibérica. Estudos e Memórias, 10. Lisboa: UNIARQ. 364 p.

GONÇALVES, V. S. - SOUSA, A. C. (2018) - Casas Novas, numa curva do Sorraia (no $6^{\circ}$ milénio a.n.e. e a seguir). Estudos e Memórias, 11. Lisboa: UNIARQ. 279 p.

MORÁN HERNÁNDEZ, M. E. (2019) - El asentamiento prehistórico de Alcalar (Portimão, Portugal). La organización del território y el proceso de formación de un estado prístino en la Bahía de Lagos en el tercer milenio a.n.e. Estudos e Memórias, 12. Lisboa: UNIARQ. 312 p. + 4 extratextos. 


\section{estudos \&
memórias}

\section{A CERÂMICA GREGA \\ DO CASTELO DE CASTRO MARIM}

Ana Margarida Arruda

Daniela Ferreira

Elisa de Sousa 


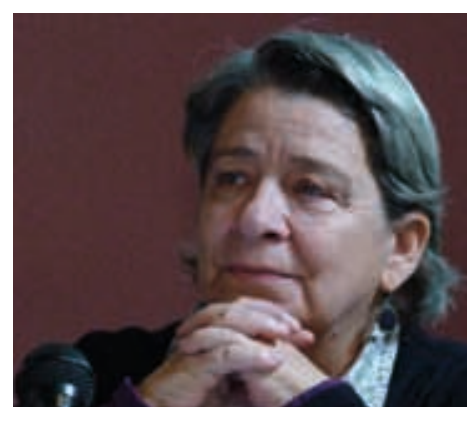

Ana Margarida Arruda é Investigadora Principal com Agregação da Universidade de Lisboa e Professora da Faculdade de Letras de Lisboa na licenciatura em arqueologia, e mestrados de Arqueologia e História Marítima, tendo dado colaboração eventual nos cursos de Mestrado das Universidade de Évora e de Sevilha e nos de doutoramento da Universidade Complutense de Madrid. No ano de 2004, o Prémio Gulbenkian de Arqueologia foi atribuído ao seu livro «Los fenicios en Portugal», editado em Barcelona, e em 2018 ganhou o Prémio Científico (menção honrosa) Universidade de Lisboa, na área de História e Filosofia. Tem cerca de 250 títulos publicados, entre livros, artigos em revistas nacionais e internacionais, capítulos de livros (Portugal, França, Bélgica, Espanha, Inglaterra, Itália, Estados Unidos, Tunísia), e contribuições em Actas de Congressos. Efectuou mais de três dezenas de conferências a convite de várias entidades, em Portugal e no estrangeiro. Dirigiu oito dissertações de doutoramento, estando cinco outras em curso, e 35 de mestrado, tendo participado em várias provas académicas como arguente e/ou membro do júri em Universidades Portuguesas, Espanholas e Francesas. Foi investigadora principal em dois projectos competitivos financiados pela FCT. É investigadora de três projectos internacionais e consultora científica de outros três.Pertence aos conselhos de redacção de várias revistas nacionais e internacionais. Foi por diversas vezes avaliadora de projectos e de bolsas de investigação promovidos pelo Governo Espanhol, concretamente Ramón y Cajal e ANEP, e pela Região Autónoma da Catalunha (AGAUR).

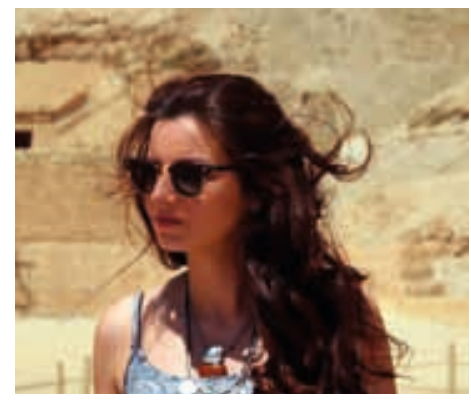

Daniela de Freitas Ferreira, nascida em 1989, é natural do Porto. Frequentou a Faculdade de Letras da Universidade do Porto (UP), onde se licenciou em Arqueologia, em 2010. Em 2012, recebe, pela mesma instituição, o grau de Mestre com a defesa de uma dissertação intitulada "Memória coletiva e formas representativas do espaço religioso", avaliada com a classificação máxima de 20 valores. Participou, desde então, em vários projectos de investigação promovidos pelo Departamento de Ciências e Técnicas do Património da UP, realizando escavações e trabalho técnico de gabinete e estudo de materiais arqueológicos. Entre 2012 e 2014, desenvolveu igualmente investigações na área do Património Imaterial, que resultaram na publicação de três livros da sua coautoria. No ano letivo de 2014/2015 iniciou o seu doutoramento enquanto bolseira da Fundação para a Ciência e Tecnologia, com vista ao estudo da cerâmica grega e de aspectos da Idade do Ferro na fachada atlântica da Península Ibérica. Integra, desde esse momento, a unidade de investigação e desenvolvimento CITCEM - Centro de Investigação Transdisciplinar "Cultura, Espaço e Memória". Desde o início do doutoramento colabora ainda com o Centro IBERIA GRAECA, sediado na Catalunha, contribuindo para a construção de uma base de dados das importações gregas na P.I. É autora e coautora de livros, capítulos de livros, posters, artigos em publicações científicas periódicas nacionais e internacionais e coeditora das actas da reunião científica "Greek art in Motion». Colaborou na organização de congressos internacionais e exposições, participando igualmente em diversas escavações arqueológicas em Portugal e no estrangeiro.

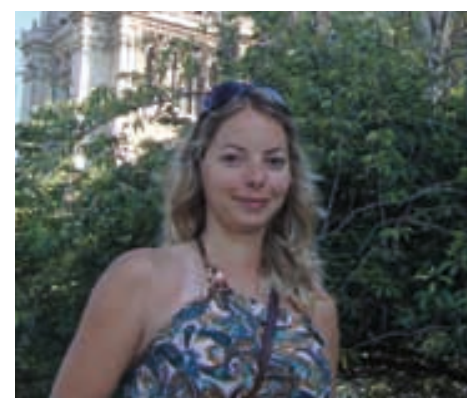

Elisa de Sousa, nascida em 1981, em Setúbal, é Professora Auxiliar na Faculdade de Letras da Universidade de Lisboa. Nesta instituição, obteve a sua licenciatura (2003), o grau de mestre, com a dissertação intitulada "A cerâmica de tipo Kuass no Algarve: os casos de Castro Marim e Faro" (2006), e o grau de doutor, com a dissertação intitulada "A ocupação pré-romana da foz do estuário do Tejo" (2011). Desde então, participou em vários projectos de investigação nacionais e internacionais, centrados sobretudo no estudo das ocupações humanas da Idade do Ferro e do período Romano-Republicano em várias áreas da Península Ibérica. Neste âmbito, colaborou ainda em várias escavações arqueológicas em Portugal e no estrangeiro (Espanha, Itália e Tunísia). É autora de dois livros e também de vários artigos em revistas científicas nacionais e internacionais, tendo participado em várias dezenas de congressos da especialidade, quer em Portugal, quer na Europa. 


\section{Índice}

1. Nota prévia $\quad 9$

2. O Castelo de Castro Marim e a sequência da sua ocupação durante a Antiguidade 13

3. A cerâmica grega do Castelo de Castro Marim e o seu contexto arqueológico 21

3.1. O conjunto de cerâmica grega do Castelo de Castro Marim 21

3.2. A época arcaica $\quad 25$

3.3. A época clássica 26

3.3.1. Os vasos de figuras vermelhas 26

3.3.1.1. As kilikes 26

3.3.1.2. Os skyphoi 40

3.3.1.3. As pelikai 41

3.3.1.4. A lekythos aribalística 42

3.3.1.5. Indeterminados $\quad 42$

3.3.2. A cerâmica ática de verniz negro 43

3.3.2.1. As taças Cástulo $\quad 44$

3.3.2.2. As taças da Classe Delicada 57

3.3.2.3. As plain rim cups 59

3.3.2.4. As stemless cups $\quad 61$

3.3.2.5. Os bolsais (Lamboglia 42B-a) 64

3.3.2.6. Os skyphoi (Lamboglia 43) 66

3.3.2.7. Os kantharoi 68

3.3.2.8. A mug 69

3.3.2.9. As páteras da forma 21 (Incurving Rim Bowl) 70

3.3.2.10. As páteras da forma 22 (Outturned Rim Bowl) 71

3.3.2.11. As páteras da forma 21 ou 22 (Incurving Rim Bowl /Outturned 74 Rim Bowl)

3.3.2.12. Os pratos de peixe (Fish Plate / forma 23 de Lamboglia) 81

3.3.2.13. Os pratos Jehasse 116 (Rolled Rim) 85

3.3.2.14. O saltcellar 86

3.3.2.15. As pequenas taças da forma 21/25B 87

3.3.2.16. A lekanis 88

3.3.2.17. A lucerna $\quad 89$

3.3.2.18. Os fragmentos decorados de forma indeterminada 89

3.3.2.19. Os fragmentos de parede de forma indeterminada 91

$\begin{array}{ll}3 \cdot 3 \cdot 2.20 \text {. As asas } & 95\end{array}$

3.3.3. As ânforas gregas $\quad 98$

4. Conclusão 103

5. Bibliografia 109 


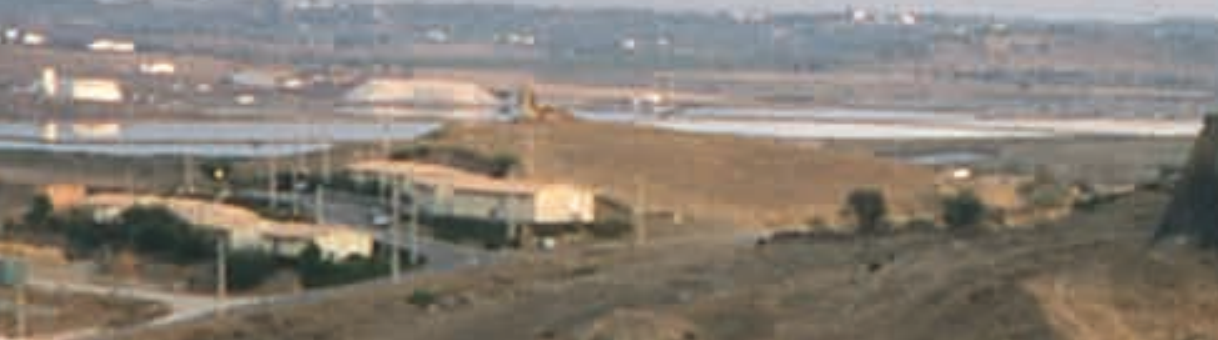

2
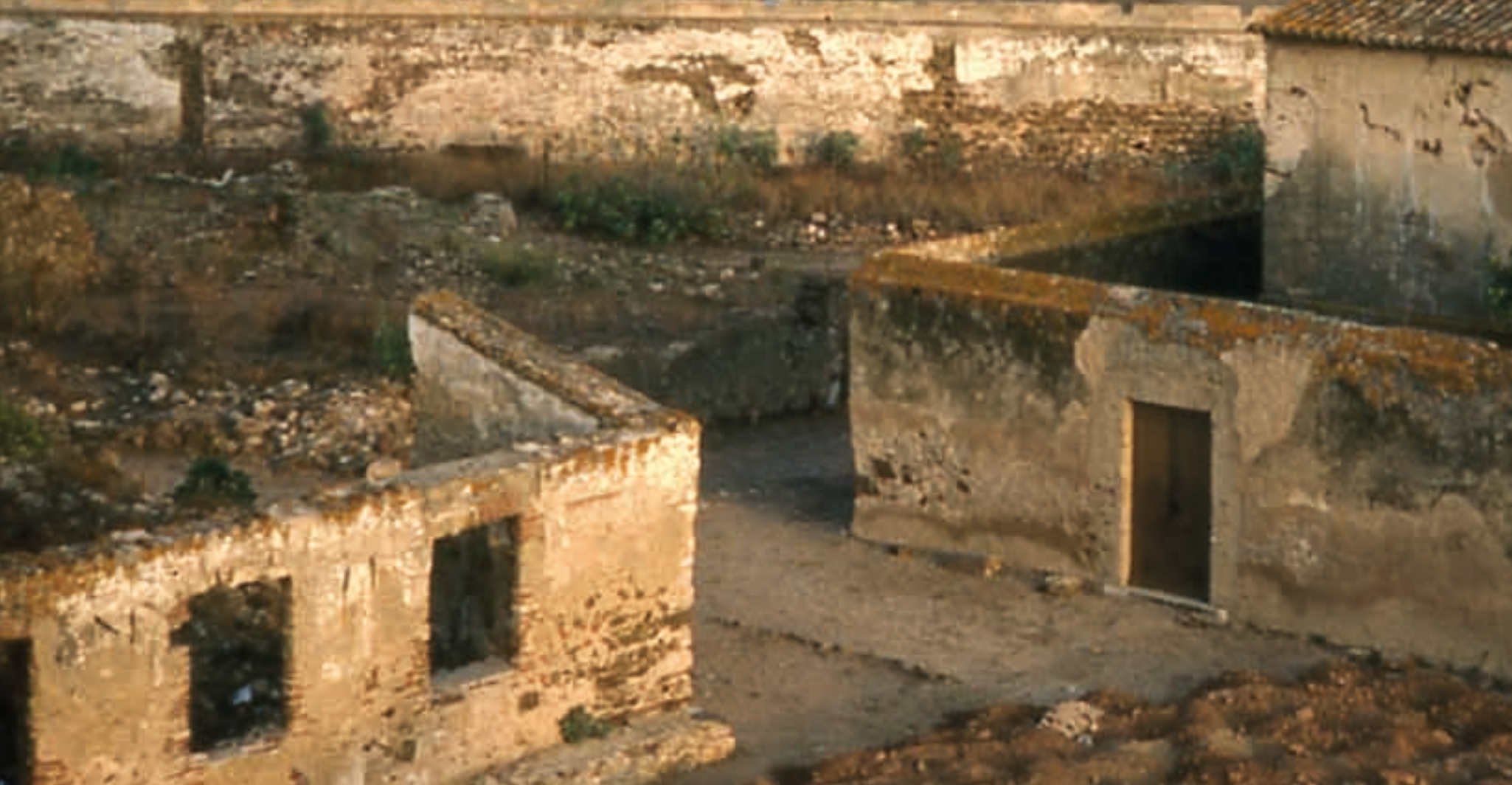

S.

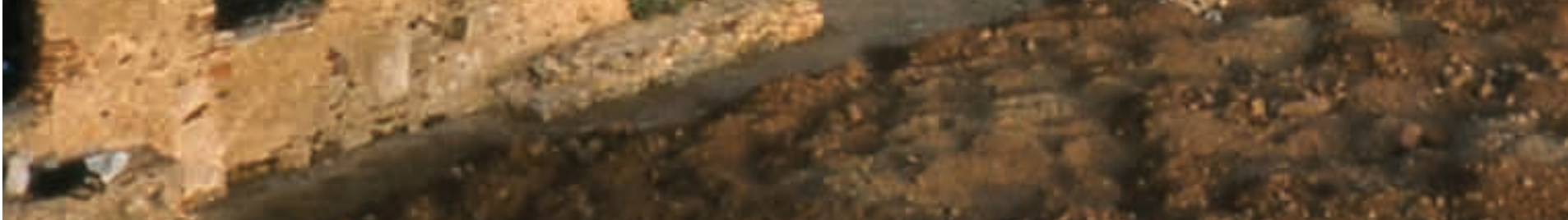

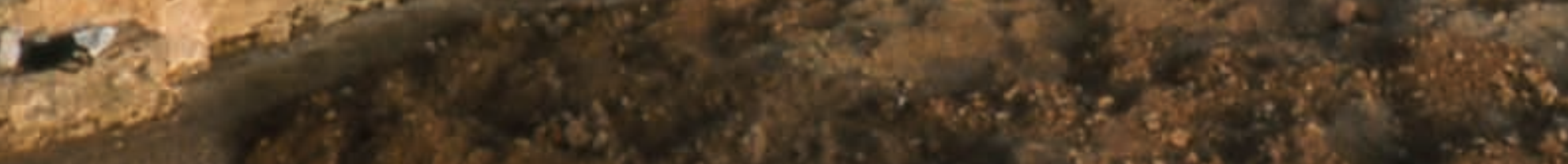


Guadiana visto do Castelo de Castro Marim (fotografia de Ana Margarida Arruda). 


\section{Nota prévia}

Os 55 fragmentos de cerâmica grega do Castelo de Castro Marim publicados em 1997 por uma de nós (Arruda 1997) correspondiam aos encontrados nas campanhas de trabalhos arqueológicos levadas a efeito no sítio algarvio, entre 1983 e 1988. O retomar das escavações, no início do século XXI, permitiu alargar consideravelmente a área escavada, tendo o número de vasos gregos recuperados aumentado muito significativamente. Alguns destes novos achados foram sendo dados a conhecer em diversos trabalhos (Arruda 2003, 2005, 2007a, 2007b, 2007c, 2008a, 2008b, 2009), mas a publicação integral do conjunto justificava-se, até porque o seu significado merece uma discussão mais alargada, que tenha em consideração os contextos de recolha e as respectivas associações de materiais. Por outro lado, se o quadro morfológico não se alterou substancialmente, nem aliás a representatividade percentual das formas ou a relação entre vasos pintados e vasos de verniz negro, o aparecimento de um fragmento do Coríntio Médio modificou o conhecimento sobre o abastecimento de produtos gregos a Castro Marim, quer no que se refere à cronologia quer no que diz respeito aos centros abastecedores. Os raros fragmentos de ânforas gregas, até agora inéditos, são também incorporados neste trabalho, que sintetiza toda a informação respeitante às importações gregas presentes no sítio da foz do Guadiana.

Neste livro, discutem-se estas importações à luz de outros dados relevantes sobre a presença de cerâmica grega na Península Ibérica, muitos dos quais estavam, em 1997, indisponíveis porque se encontravam inéditos ou porque não tinham sido ainda encontrados.

Os vasos gregos de Castro Marim puderam agora ser estudados também à luz de outros dados sobre as ocupações antigas do sítio entretanto adquiridos por estudos de natureza diversa, concretamente da fauna e da flora. O seu significado está assim muito para além do poder aquisitivo dos seus habitantes, ultrapassando também as questões relacionadas com a sua integração nas rotas comerciais mediterrâneas dos séculos VI a IV a.n.e. Podem também ser lidos em função do seu uso quotidiano e do consumo dos alimentos, líquidos e sólidos, que eles permitiam. 


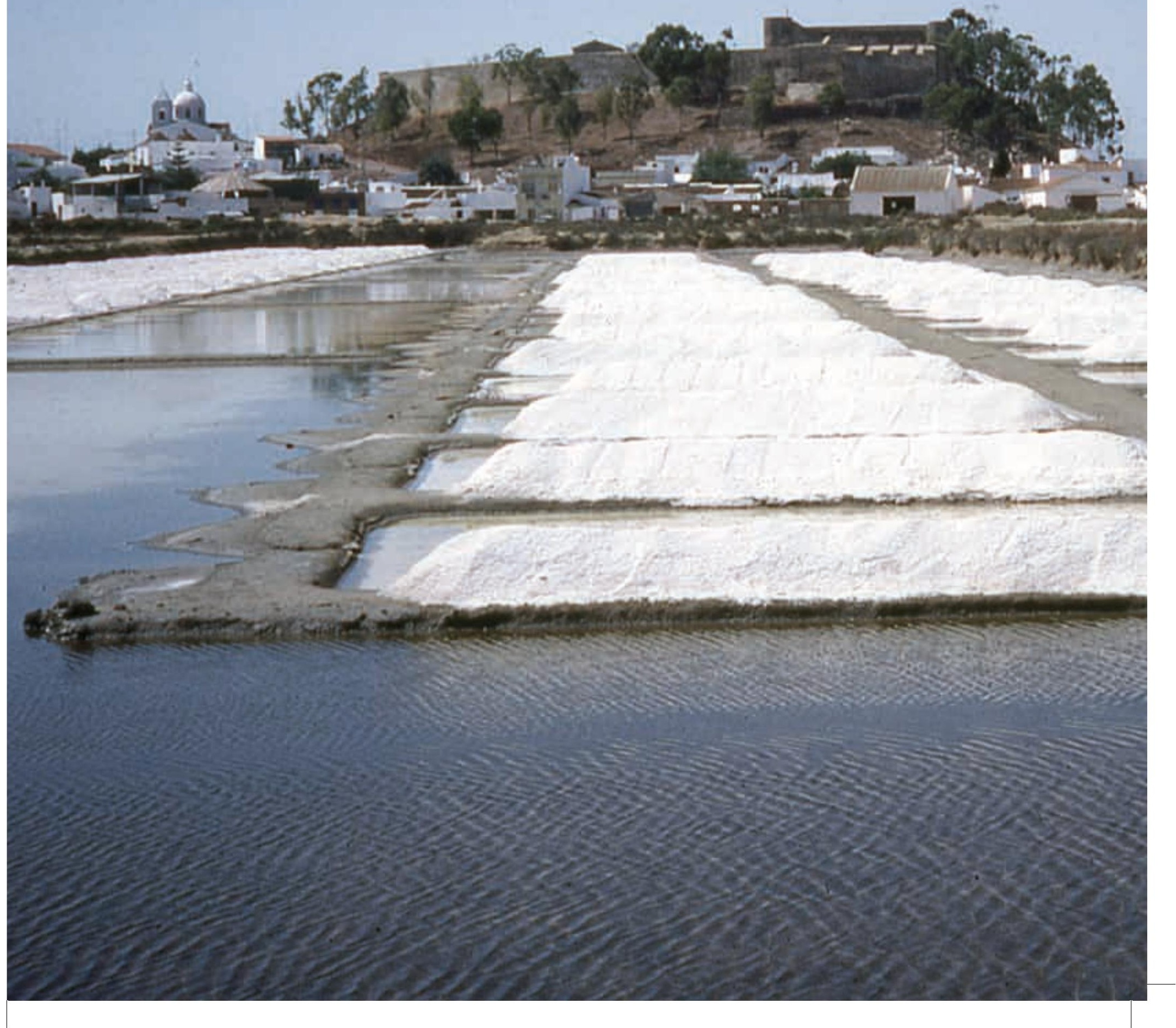





\section{O Castelo de Castro Marim e a sequência da sua ocupação durante a Antiguidade}

O Castelo de Castro Marim localiza-se na margem direita do estuário do Guadiana, implantandose numa colina de formato circular, de onde se domina, visualmente, um amplo território.

As escavações levadas a efeito no Castelo de Castro Marim foram prolongadas, contando com 10 campanhas de trabalhos de campo programadas no contexto de projectos de investigação, desenvolvidas na década de 80 do século passado (seis) e entre 2000 e 2003, mas outros trabalhos, de carácter preventivo, tiveram lugar em anos mais recentes (2015 e 2017).

A área escavada é relativamente ampla, correspondendo a $293 \mathrm{~m}^{2}$, o que permitiu estabelecer um faseamento para a ocupação antiga do sítio, tendo ficado comprovado que esta se iniciou ainda durante o Bronze Final (Oliveira 2006, 2011), ainda que seja a da Idade do Ferro a que se encontra mais bem documentada, através de abundantes dados, quer ao nível das estruturas (domésticas e defensivas), quer no que se refere aos materiais.

A integração de Castro Marim nas redes de comércio de produtos do Mediterrâneo Oriental, desde a primeira metade do $1^{\circ}$ milénio a.n.e., ficou evidenciada, tendo os dados identificados permitido verificar que é ao contacto com agentes exógenos, a partir da primeira metade do século VII a.n.e., que podemos assacar a responsabilidade pelas profundas afinidades com as comunidades fenícias instaladas no círculo do estreito de Gibraltar.

Castro Marim parece testemunhar uma fundação indígena certificada através da presença exclusiva de cerâmica autóctone em estratos que se reportam a cronologias mais recuadas. Ainda que estes primeiros níveis de ocupação sejam difíceis de caracterizar, em resultado do mau estado de conservação dos vestígios arquitetónicos, parece ocorrer um claro fenómeno de ocupação continuada entre o final da Idade do Bronze e a Idade do Ferro, sucedendo-se as fases construtivas de uma e de outra, através da destruição ou reutilização das arquiteturas pré-existentes.

Entre o século V e o III a.n.e., o comércio a longa distância conhece grande expansão (Arruda 1999/2000, 2000, 2003, 2005, 2007a, 2007b, 2007c, 2008a, 2008b; Arruda et al. 2006; Freitas 2005; 


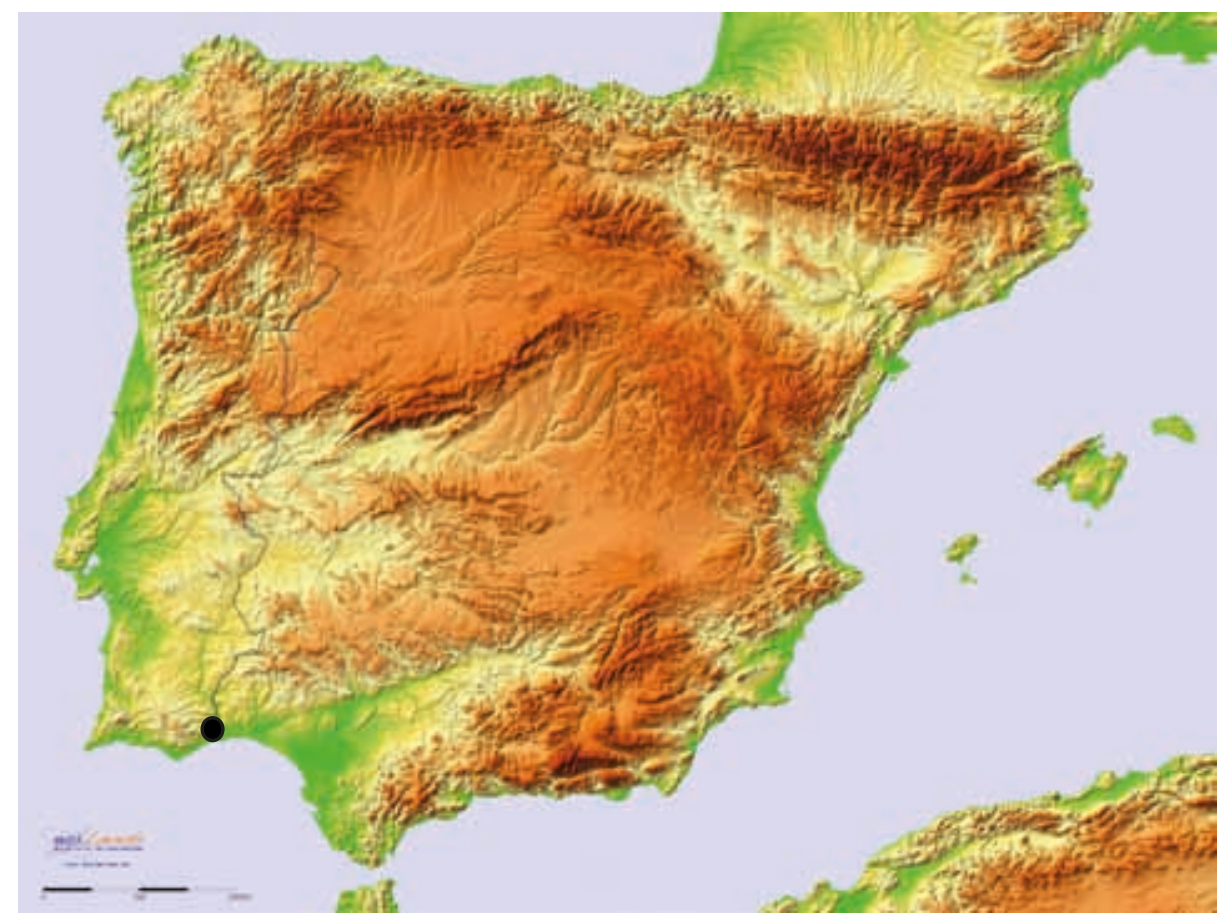

Fig. 1 - Localização de Castro Marim na Península Ibérica.

Sousa 2009; Sousa - Arruda 2010), decrescendo as importações a partir de meados do século III a.n.e., para serem novamente retomadas, em maior quantidade, apenas a partir da segunda metade do século I a.n.e.

A sequência ocupacional do sítio foi definida através das estruturas e contextos arqueológicos escavados e das suas respectivas relações estratigráficas. Todos eles puderam ser datados pelos materiais arqueológicos que lhes estavam associados, e também pela posição relativa que ocupam na longa e complexa matriz que foi elaborada com base nos dados recolhidos no terreno. Por outro lado, houve oportunidade de proceder à realização de datações radiométricas, obtidas sobre dados da biosfera marinha e terrestre, que foram devidamente tratadas com recurso à análise estatística de inferência bayesiana (Arruda et al. 2013), o que assegura a consistência da cronologia atribuída a cada uma das fases de ocupação identificadas.

Como se disse atrás, os dados arqueológicos referentes à Idade do Ferro incorporam estruturas arquitectónicas e espólios de natureza diversa. Entre os primeiros, destaca-se uma muralha de "casamatas" que se desenvolve no limite superior da vertente Norte, respeitando os limites da colina, implantada justamente sob o muro defensivo construído na Idade Média, e que se data do século VII a.n.e. (Arruda - Oliveira - Freitas 2017: 449). Terá estado em funcionamento até, pelo menos, ao final do século IV a.n.e. As restantes incorporam diversas células, a maioria das quais compondo edifícios, cujos pormenores arquitectónicos, as particularidades construtivas e os materiais nelas recolhidas fundamentaram uma interpretação funcional de carácter eminentemente religioso (Arruda et al. 2009; Arruda - Oliveira - Freitas 2017), ao longo de toda a diacronia sidérica (entre os finais do século VIII e o III a.n.e.). Neste contexto, não podemos deixar de referir aqui, desde já, o compartimento 31, interpretado como bothros, cuja UE [89] ofereceu, como se verá adiante, uma quantidade apreciável de cerâmica grega, integralmente datada dos finais do século $V$ a.n.e. Trata-se de um ambiente particularmente bem conservado, onde o número de vasos completos (de mesa e de transporte) é de registar. 


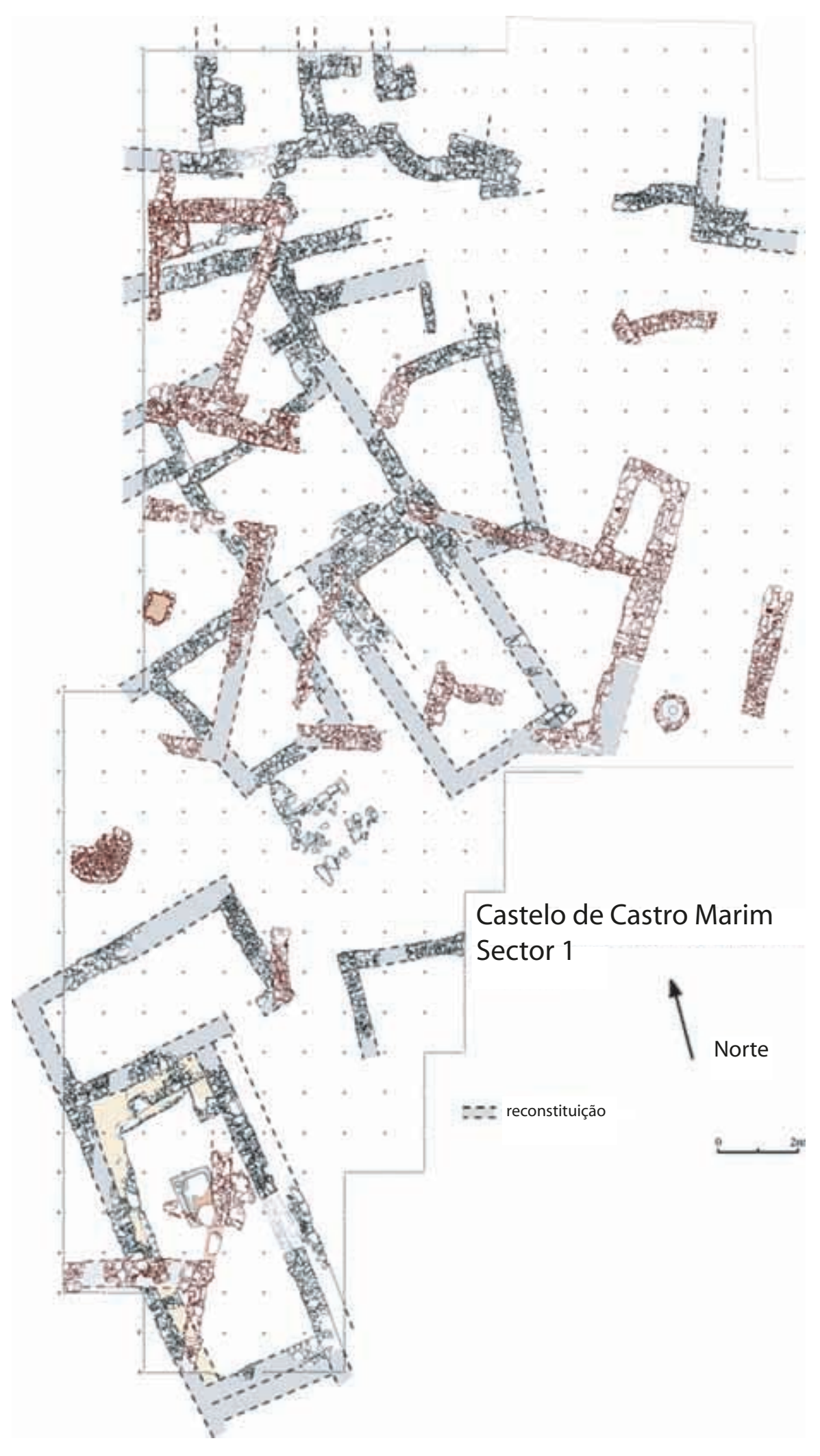

Fig. 2 - Sobreposição das plantas arquitectónicas da fase IV (séc. VI) e V (séc. VI a III) (segundo Arruda Freitas 2008). 


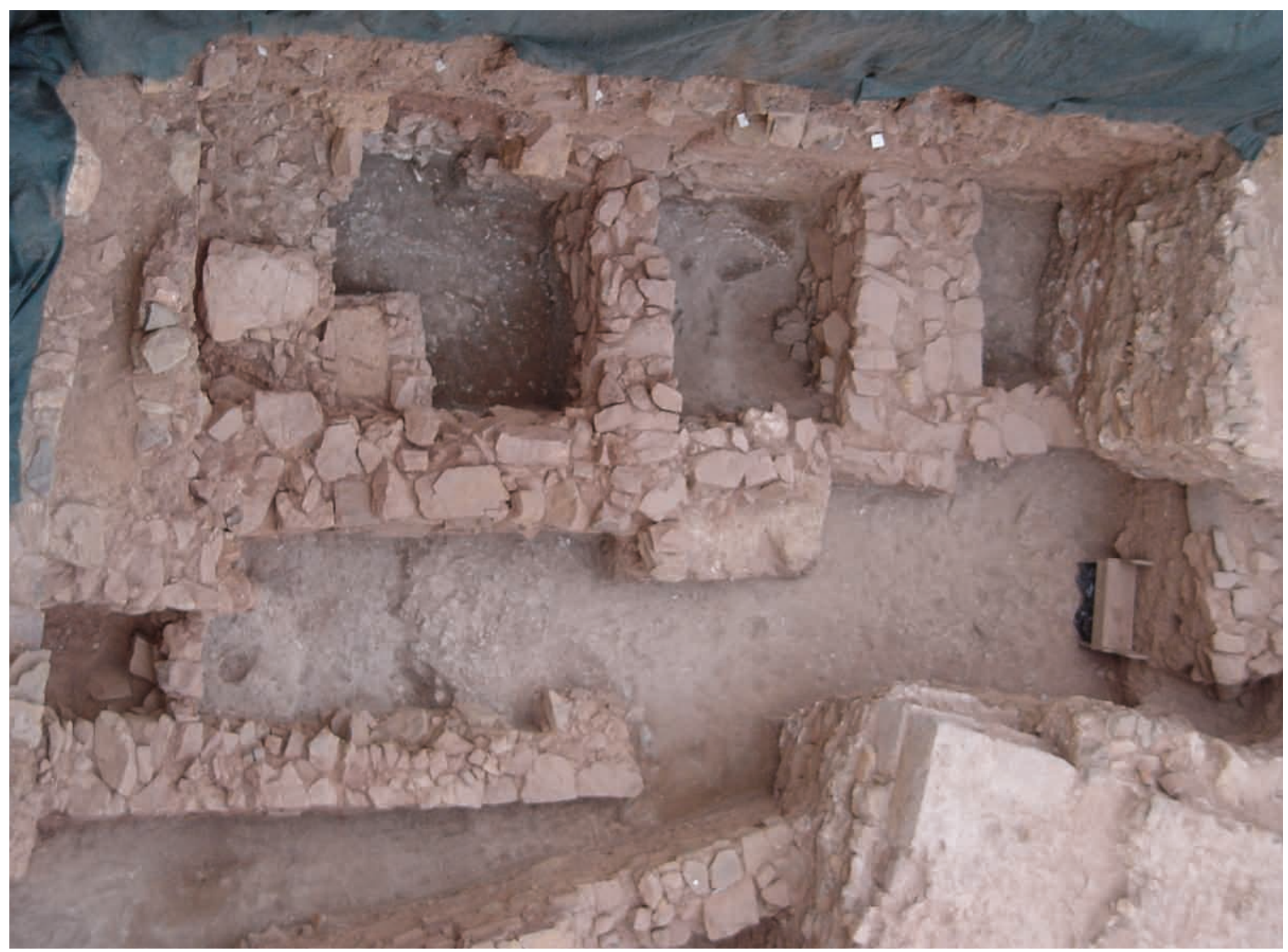

Fig. 3 - Muralha de casamatas, construída no século VII a.n.e., identificada na vertente Norte da colina do Castelo de Castro Marim (Arquivo Fotográfico do Projecto MARCAS).

Entre os finais do século VIII e os últimos anos do século VI a.n.e., a ligação de Castro Marim ao mundo fenício ocidental, concretamente à área da baía de Cádis, à costa de Málaga e ao baixo Guadalquivir, é profunda e intensa, podendo mesmo presumir-se, inclusivamente, a presença física de agentes mediterrâneos no local, realidade que, para além da arquitectura e das técnicas construtivas, os materiais arqueológicos permitiram verificar. Entre estes últimos, as cerâmicas dominam, com formas, tecnologia de produção e tratamento das superfícies de características exógenas. Os vasos de fabrico manual de tradição local permaneceram no conteúdo dos inventários, apesar de a decoração de alguns deles remeter também para um universo mais vasto, que podemos aqui denominar de "tartéssico-orientalizante" (Arruda - Oliveira - Freitas 2017: 446).

A relação do sítio da foz do Guadiana com a região meridional da Andaluzia mantém-se na chamada II Idade do Ferro. A partir de finais do século $V$ a.n.e., integrou-se no que podemos designar como Turdetânia, sofrendo, paralelamente, fortes influências púnico/gaditanas (Arruda 1999-2000, 2000, 2001, 2003, 2005; Arruda et al. 2006; Sousa - Arruda 2010). São sobretudo os materiais arqueológicos que permitiram perceber essa inclusão, nomeadamente as importações de produtos alimentares preparados nessas áreas e envasados em ânforas, mas também os manufacturados, como a cerâmica de mesa. A própria cerâmica grega pode ter atingido o Ocidente em geral e o Castelo de Castro Marim em particular através do porto de Cádis, "metrópole" que os importaria directamente da Grécia para os consumir, mas também para os re-distribuir.

Os grupos humanos instalados na colina onde, na Idade Média, se ergueu o Castelo de Castro Marim tiveram certamente, e por sua vez, um papel preponderante na organização do território envolvente. Território que foi explorado no que concerne à produção de alimentos e como área 


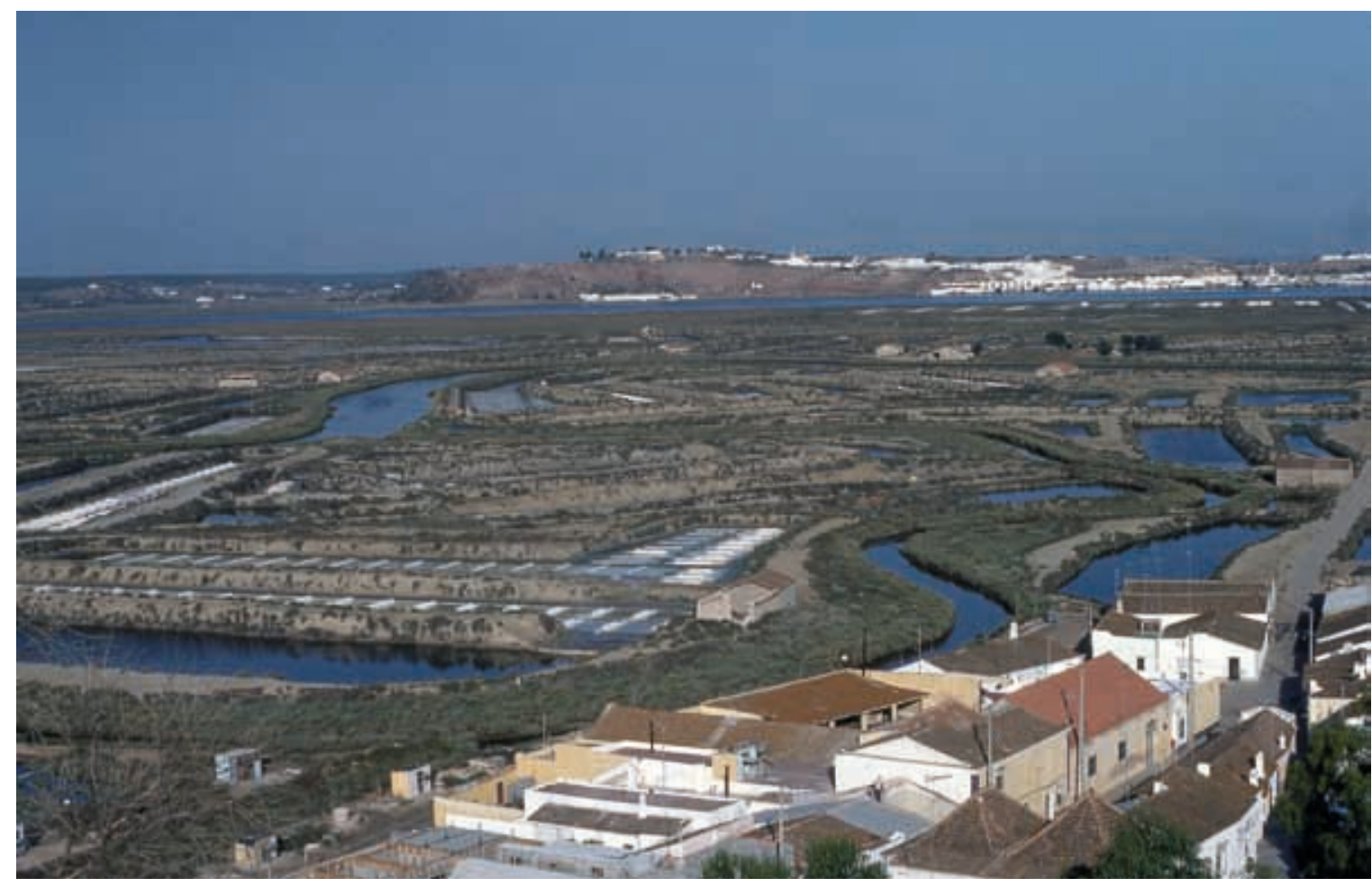

Fig. 4 - A paisagem envolvente de Castro Marim - vista do Castelo para o Guadiana (Arquivo Fotográfico do Projecto MARCAS) .

de pastagens. Com efeito, o estudo da fauna (Davis 2007) evidenciou a alta percentagem de ovicaprídeos e de bovinos, mas o pastoreio foi também documentado indirectamente através das análises palinológicas tendo a presença de elementos nitrozoógenos confirmado o aproveitamento de pastagens de gramíneas na actividade pastoril (Hernandez Carretero 2008: 141). O bosque relativamente denso nas proximidades (Hernandez Carretero 2008: 140) era favorável à actividade cinegética, provada pelas percentagens expressivas de coelhos e veados (Cervus elaphus) a que poderíamos ainda juntar alguns dos Sus sp. identificados, que podem corresponder a javalis (Davis, 2007). Os equídeos (Equus sp.) (Davis 2007) e talvez ainda os Canis familiaris podem ainda associarse à referida atividade actividade cinegética.

O estudo de restos botânicos particularmente bem conservados (Queiroz et al. 2006), datados através da cerâmica grega (taças Cástulo) dos finais do século V a.n.e., possibilitou outras leituras acerca da comunidade instalada no sítio durante a II Idade do Ferro, que completam as fornecidas pelas análises palinológicas (Hernández Carretero 2008, 2014).

As últimas evidenciam a importância da cerealia (Hernandez Carretero 2014: 813, fig. 1), mostrando as espécies nitrófilas que compõem o abundante grupo herbáceo (NAP) fenómenos antrópicos de considerável relevância (Ibidem: 814) e a presença de espécies arvenses que crescem nos campos cultivados, como é o caso de Centaurea, Plantago coronopus type, Rumex acetosella type, Polygonum, etc., confirmam a peso dos campos agrícolas na economia do sítio.

As sementes comprovam esse peso, destacando-se no conjunto a cevada (Hordeum vulgarae), com 95,3\%, sendo o trigo (Triticum compactum) insignificante (Queiroz et al. 2006: 15 e 25). Os produtos hortícolas foram registados em Castro Marim, concretamente através, sobretudo, da favinha (Vicia faba minuta), sendo o grão de bico (Cicer arietinum) apenas residual (ibidem), todos com cronologias dos séculos $V$ e IV a.n.e. 
Ao nível dos frutos, os pinhões tiveram importância, o que se pode deduzir não só pelas sementes identificadas, mas também pelas escamas ovulíferas de Pinus pinea, bem como pelos carvões de madeira deste tipo de árvore (ibidem). Apesar de, entre as madeiras carbonizadas, se terem reconhecido abundantes fragmentos de Olea europaea, desconhecemos se o seu fruto foi consumido directamente, ou usado para a produção de azeite, ou para ambos. A mesma situação regista-se no caso da Vitis, presente nas variantes vinifera e sylvestris, podendo admitirse, contudo, quer o consumo do fruto quer a sua utilização para a produção de vinho.

A relação do consumo de alguns destes alimentos com os vasos gregos é evidente, porque muitos destes últimos terão sido usados para consumir os primeiros, ainda que, naturalmente, muitos recipientes de outras categorias tenham tido a mesma funcionalidade. Ainda assim, a presença de vitis vinifera em níveis dos séculos $V$ e IV a.n.e. e a predominância de formas destinadas ao consumo do vinho devem ser devidamente conectadas.

A importância que Castro Marim assumiu durante a Idade do Ferro é muito relevante em termos estritamente locais, mas também pelas relações internacionais que manteve e que lhe permitiram constituir-se como um núcleo urbano de primeira grandeza no contexto regional. A antiga Baesuri, o nome que manteve mesmo durante a sua ocupação romana e que as cunhagens monetárias deixaram registado, conservou a sua importância e vitalidade até pelo menos ao século I, momento em que outros sítios de fundação coeva e idêntica matriz cultural, como Balsa e Ossonoba, Ihe retiraram grande parte do protagonismo. 


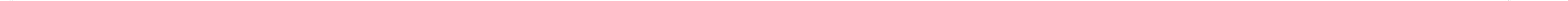





\section{A cerâmica grega do Castelo de Castro Marim e o seu contexto arqueológico}

\subsection{O conjunto de cerâmica grega do Castelo de Castro Marim}

Como já se referiu em 1., o primeiro conjunto de cerâmica grega do Castelo de Castro Marim foi dado a conhecer à comunidade científica em 1997, pela mão de uma de nós (Arruda 1997), onde se reuniu e classificou os achados das seis campanhas de trabalhos campo ocorridas ainda no século 20, concretamente entre 1983 e 1988. A continuação das intervenções nos primeiros quatro anos da presente centúria permitiu aumentar significativamente o número de peças identificadas e clarificar o panorama conhecido para as importações gregas, confirmando a preferência por determinadas formas e dando a conhecer novos gostos, devidamente associados a um quadro cronológico de importações bem conhecido. Os novos achados foram sendo publicados, ainda que de forma parcial e compartimentada, em diversos trabalhos que visaram dar a conhecer as várias fases de ocupação da Idade do Ferro de Castelo de Castro Marim (Arruda 2003, 2005, 2007a, 2007b, 2008a, 2008b, 2009). Neste trabalho, procura-se levar a efeito a publicação integral do conjunto, discutindo-se as diferentes etapas de recepção dos produtos gregos e as características de cada uma delas.

A quantificação do conjunto da cerâmica grega do Castelo de Castro Marim seguiu os critérios estabelecidos na reunião de Mont Beauvray (Arcelin - Tuffreau-Libre 1998) para a atribuição do Número Mínimo de Indivíduos (NMI), atendendo à procedência contextual das peças, às características do seu fabrico e ao valor mais elevado das diferentes partes morfológicas de cada tipo, considerando-se ainda os que tipologicamente não permitiram uma classificação específica.

A cerâmica grega do Castelo do Castro Marim totaliza 315 fragmentos, dos quais apenas um se inclui na fase arcaica, pertencendo os restantes ao período clássico. Tal realidade justifica, em grande parte, o facto de 312 fragmentos corresponderem a produções áticas, tendo dois origem em Corinto e um outro ser, muito provavelmente, oriundo de Quios. As coríntias englobam não 


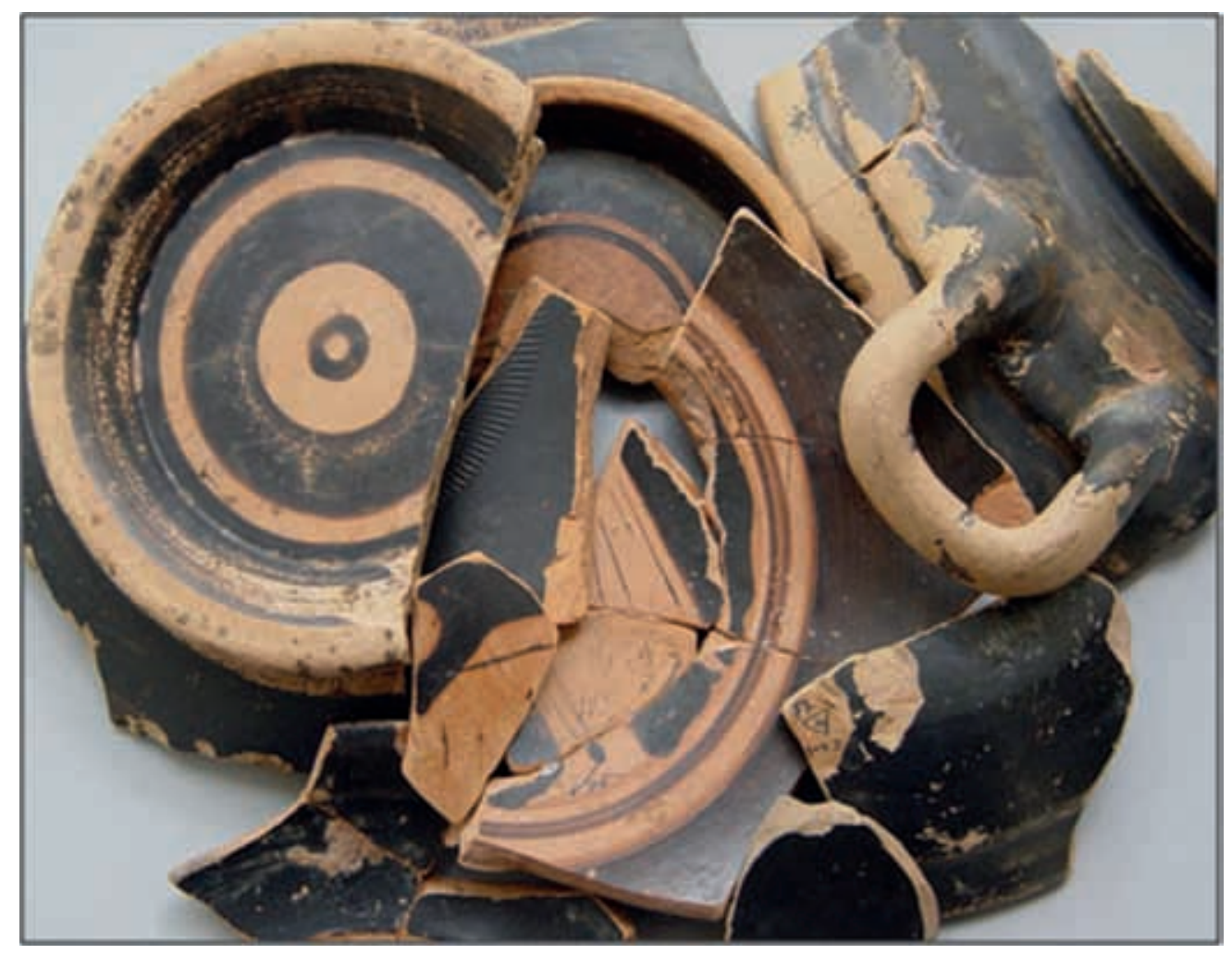

Fig. 5 - Cerâmica grega (ática) do Castelo de Castro Marim (fotografia de Ana Margarida Arruda).

apenas o olpe de figuras negras de época arcaica, do Coríntio Médio (Arruda 2005, 2007c), mas também uma ânfora datada do século IV a.n.e. O primeiro, cuja cronologia deve ser colocada no segundo quartel do século VI a.n.e., integrando-se, portanto, no Coríntio Médio (Arruda 2005, 2007, 2019), é oriundo de níveis primários de ocupação atribuídos à primeira metade do século VI a.n.e., tendo sido encontrado associado a produções de cerâmica de engobe vermelho, cerâmica cinzenta e fíbulas de tipo Achebuchal (Arruda - Freitas 2008), citando apenas alguns exemplos que comprovam a supracitada atribuição cronológica.

Nas importações de época clássica, dominam, de forma esmagadora, os produtos áticos, sendo as excepções as duas ânforas, uma coríntia e outra, possivelmente, de Quios. Entre os primeiros, a cerâmica decorada com figuras vermelhas é minoritária (46 fragmentos, que equivalem a 31 indivíduos), destacando-se as kilikes de pé baixo. Estas datam, maioritariamente, da primeira metade do século IV a.n.e., havendo, contudo, duas peças, que podem ser atribuídas ao "Círculo do pintor de Marlay" (Arruda 1997, 2007c) e que assim podem ser reportadas a produções do último quartel do século $V$ a.n.e. As restantes kilikes apresentam detalhes que permitem a sua integração entre o "Grupo do Pintor de Viena 116", ainda que apenas em quatro fragmentos essa integração seja segura. Muito mais raras são as pelikai (dois exemplares), tendo-se contabilizado também dois skyphoi, datados do último quartel do século $V$ a.n.e. e da primeira metade do século IV a.n.e. e uma lekythos aribalística, da mesma cronologia.

A cerâmica de verniz negro prevalece de forma clara, com 263 exemplares (182 indivíduos), destacando-se no conjunto as taças de pé baixo - stemless cup (94 fragmentos, 74 indivíduos), onde se identificaram 65 fragmentos de "taças Cástulo" (55 indivíduos), designadas também, sobretudo pela escola anglo-saxónica, por “inset lip”, e que, na tipologia de N. Lamboglia (1951) foram recolhidas na forma 42A. Seis pés altos e moldurados, ligados à pança por um ressalto bem 
marcado e em reserva, e dois bordos foram incorporados no grupo da "Classe Delicada", que assim totalizam sete indivíduos. Uma terceira variante de stemless cup, com as paredes da pança ligadas ao pé através de uma única curvatura ininterrupta, e que corresponde às taças «plain rim cup type (» da Ágora de Atenas (Sparkes - Talcott 1970: 92, n 432-433), está representada por cinco fragmentos (cinco indivíduos). Assemelham-se às taças Cástulo no que se refere ao pé, às asas e às dimensões gerais, acompanhando a evolução crono-tipológica destas últimas, sendo, no entanto, menos populares. Os restantes fragmentos (16, sete indivíduos) que compõem o conjunto de taças de pé baixo dizem respeito a bordos, fundos e pés de exemplares cujas especificidades formais não permitem a determinação da variante a que pertencem.

Cinco peças (cinco indivíduos) inserem-se no grupo dos bolsais, caracterizando-se pela marcada concavidade na ligação da parede externa ao pé. Trata-se de vasos que podem datar do último quartel do século $V$ a.n.e., sobretudo se tivermos em consideração alguns marcadores cronológicos, como é a curvatura única da parede, por oposição à dupla curvatura que caracteriza as peças produzidas na centúria seguinte (Ibidem: 107).

O grupo dos vasos para consumir vinho encerra-se com os sete fragmentos (sete indivíduos) que incluímos no grupo dos skyphoi.

Menos numerosas que as taças, mas, ainda assim, muito significativas são as 39 páteras (31 indivíduos), onde se distinguiram as variantes «incurving e outturned rim bowl» da Ágora de Atenas (Ibidem: 131), ou forma 21 e 22 de Lamboglia (1951). O início da produção das primeiras, de lábio voltado, de forma muito pronunciada, para o interior, foi colocado na primeira metade do século IV a.n.e., de acordo com os dados estratigráficos da Ágora de Atenas (Sparkes - Talcott, 1970: 131).

No que se refere às Lamboglia 22 (outtturned rim bowl), de bordo evertido e com uma cronologia de produção semelhante à forma 21, deve destacar-se a particularidade de apresentarem, na maior parte dos casos, uma banda em reserva, na superfície externa, imediatamente a seguir ao lábio.

As páteras das formas 21 e 22 de Lamboglia identificadas no Castelo de Castro Marim apresentam usualmente decoração na superfície interna do fundo. O padrão mais comum compõese de palmetas isoladas ou ligadas entre si através de caulículos, dispostas em um ou dois círculos. Estes motivos são normalmente complementados por um círculo central inciso e, em alguns exemplares, recorre-se a bandas de óvulos para delimitar o conjunto decorativo, verificando-se, a partir de 390/380 a.n.e., a substituição deste elemento por estrias feitas no torno.

Os pratos de peixe são também presença frequente entre o conjunto de cerâmica grega do sítio algarvio, tendo sido contabilizados 14 exemplares (14 indivíduos), cinco dos quais apresentam lábio pendente e seis lábio engrossado. Devem ser datados da primeira do século IV a.n.e., quer pelas suas características intrínsecas quer pela sua posição estratigráfica no sítio em estudo.

Isolados ou em associação estratigráfica com os pratos de peixe, regista-se a presença de dois exemplares de pratos da forma Jehasse 116 (Jehasse - Jehasse 1973: 208), forma conhecida por "rolled rim" de acordo com a nomenclatura da Ágora de Atenas (Sparkes - Talcott 1970: 147). Trata-se de fragmentos de fundo e pé, decorados na superfície interna do fundo com círculos de estrias semelhantes a peças atribuídas ao taller Sec-11 (Arribas et al. 1987: 215). Os pés são baixos, de perfil arredondado, simples, e com as duas faces convexas.

Com uma menor representação no cômputo geral das importações áticas de verniz negro, verifica-se igualmente a presença de kantharoi, tendo sido possível identificar três fragmentos (três indivíduos) que podem incluir-se nesta forma. Não obstante as dificuldades verificadas na classificação tipológica destas peças, pensamos tratar-se, no caso dos bordos, de exemplares da forma kantharos-moulded rim (Arruda 1997: 128). Apresentam lábio moldurado, de sessão triangular-arredondado, com paralelos mais próximo nas peças nº 707-708 da Ágora de Atenas (Sparkes - Talcott 1970: 117). Os fragmentos de pés, de difícil classificação, são moldurados, com 
espessamento central na superfície externa do fundo e decoração estampilhada na superfície interna.

Dois fragmentos de fundo são de difícil classificação. Um é plano e o que se conserva da ligação ao corpo, concretizada através de uma "garganta" pronunciada, indicia que este seria, muito provavelmente, globular. Tratar-se-ia, portanto, de um vaso fechado, o que se confirma também pelo facto de as paredes e do fundo interno estarem desprovidos de engobe, facto também constado no fundo externo. O restante, consideravelmente espesso é também aplanado e apresenta escasso diâmetro. Pode ter pertencido a um "saltcellar", a que também fizemos corresponder cinco bordos (cinco indivíduos), que se incluem mais exactamente na forma 21/25B.

Uma tampa de lekanis e um fundo de uma "mug" foram reconhecidos entre o conjunto de cerâmica grega em apreço.

Por último é necessário referir a presença de um fragmento de lucerna, forma relativamente rara na Península Ibérica, ainda que esteja testemunhada, por exemplo, no naufrágio de El Sec (Arribas et al. 1987), em Ibiza (Sánchez Fernández 1981) e, mais próximo do sítio em estudo, em Mértola (Arruda - Barros - Lopes 1998). As reduzidas dimensões do fragmento identificado em Castelo de Castro Marim não permitem a sua reconstituição gráfica ou classificação, dificultando a atribuição de uma cronologia para a produção e chegada deste produto.

Vários fragmentos não puderam ser integrados em nenhuma forma concreta, nove (oito $\mathrm{NMI}$ ) dos quais apresentam decoração estampilhada, sendo 50 (20 NMI) apenas de verniz negro, correspondendo alguns destes a porções de fundo.

São 31 as asas (nove indivíduos) que não conseguimos associar a nenhuma forma concreta, apesar de terem pertencido, quase seguramente, a vasos destinados a consumir líquidos (kilikes ou skyphoi).

De origem ática são também três fragmentos de parede de ânforas, que transportaram vinho, e que incluímos no grupo lato das ânforas "à la brosse".

Muitos dos materiais estudados neste trabalho foram encontrados em níveis arqueológicos correspondentes a ocupações primárias, pelo que assumem importância capital no estabelecimento de cronologias, quer absolutas, quer relativas, para eles próprios, mas também para os restantes, que os acompanhavam. Essas associações de materiais nos respectivos contextos foram tidas em consideração na análise que concretizámos sobre cada forma presente no conjunto em apreço. Neste âmbito, destacamos, desde já, as UEs [0078=0089] que correspondem a um contexto muito particular, pela funcionalidade que sugere, um bothros associado a uma área de culto (Arruda Freitas 2008; Arruda et al. 2009), mas também, e sobretudo, por se tratar de níveis "fechados", onde não se verificou qualquer perturbação posterior. A cerâmica grega encontrada neste depósito de características votivas é muito coerente do ponto de vista cronológico e engloba várias taças Cástulo (10 indivíduos), três taças de tipo plain rim (três indivíduos) e uma outra da Classe Delicada (um indivíduo). Está associada a outras categorias cerâmicas, nomeadamente ânforas, onde se destacam as de tipo Pellicer $B / C$ e as Mañá Pascual A4 (Ramón Torres 11.2.1.3, 11.2.1.4 e 11,2.1.6). Todas estas presenças permitem atribuir à formação de este depósito uma datação do último quartel do século $V$ a.n.e., porque mesmo que alguns materiais pudessem, individualmente, atingir já os primeiros anos da centúria seguinte, a verdade é que, em conjunto, correspondem a um "pacote" muito coerente, que permite assumir a datação que propomos.

Em outras UEs, ainda que menos densas do ponto de vista dos espólios, idênticas associações, ou outras, forneceram também importantes dados sobre a cronologia do consumo dos produtos gregos no Ocidente. Trata-se, por exemplo da UE [0679], onde uma taça da Classe Delicada surge associada a um skyphos de figuras vermelhas, decorado com grinalda de folhas de murta. Também aqui é esta associação que valida a cronologia das últimas duas décadas do século $V$ a.n.e., o 

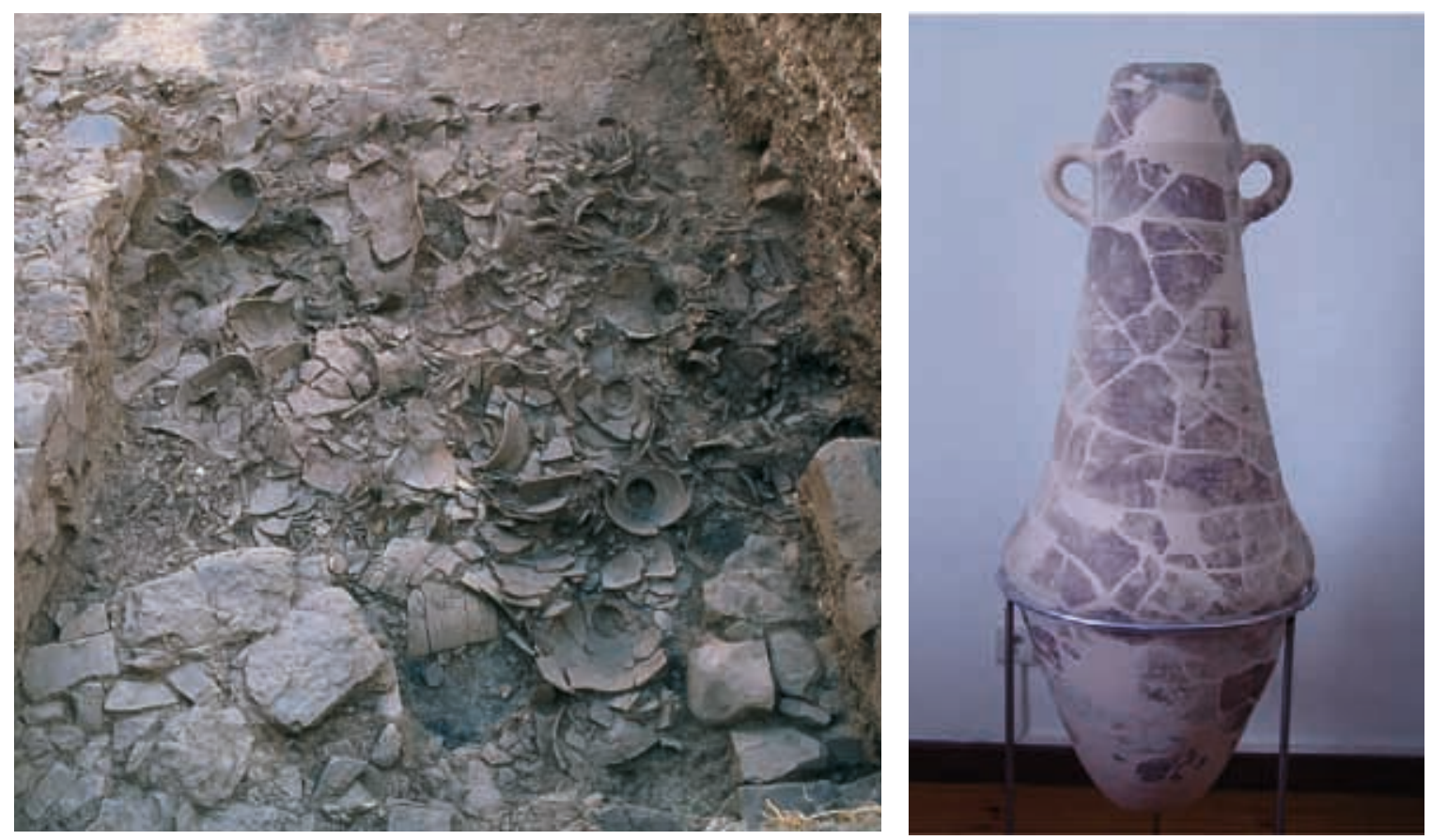

Fig. 6 - Fase V: depósito votivo do final do século V a.n.e (U.E. [0089]) e ânfora 11.2.1.3 recuperada no mesmo depósito (Arquivo Fotográfico do Projecto MARCAS).

mesmo se aplicando à UE [0766], que proporcionou três taças Cástulo e um skyphos, associados a ânforas de tipo Pellicer B/C e 11.2.1.3. de Ramon Torres.

\subsection{A época arcaica}

Um único fragmento de cerâmica grega de época arcaica foi recuperado no Castelo de Castro Marim (Arruda 2005, 2007, 2019). Trata-se da parede de um olpe de figuras negras de produção coríntia (MAR/ooo), que pode ser datado do segundo quartel do século VI a.n.e., integrando-se no Coríntio Médio.

As figuras estão integradas em dois frisos, separados entre si por linhas horizontais negras e vermelhas. A decoração é moderadamente densa, observando-se rosetas, cujos contornos gerais, bem como os das folhas, foram marcados por finos traços incisos, que ultrapassam os limites da própria roseta. Outros elementos decorativos, obtidos através da mesma técnica, estão igualmente presentes, tratando-se de simples pontos e de outras formas irregulares, trapezoidais ou semicirculares. No friso superior, é visível a pata de um quadrúpede. A decoração é canónica, sendo frequente neste tipo de vaso, concretamente olpai, mas também em oinochoai. Contudo, a atribuição a um pintor torna-se difícil atendendo à escassa dimensão do fragmento. Ainda assim, a sua inclusão no AOA Group parece possível, não só pela forma em si, mas também pelos motivos que exibe e pelos "...details incise thoughtlessly but usually with an assured touch" (Amix Lawrence 1975: p. 83), inclusão que é aqui efectuada com muitas reservas. O verniz é negro, sendo bicolor (negro e avermelhado) nas linhas que separam os dois frisos, e a pasta é bege e muito bem depurada.

O fragmento foi recolhido num nível arqueológico que corresponde a um momento de transição entre as fases Fase III e IV definidas para a ocupação antiga do Castelo de Castro Marim, cujos materiais, mas também a cronologia radiométrica, permitiram datar da primeira metade do 


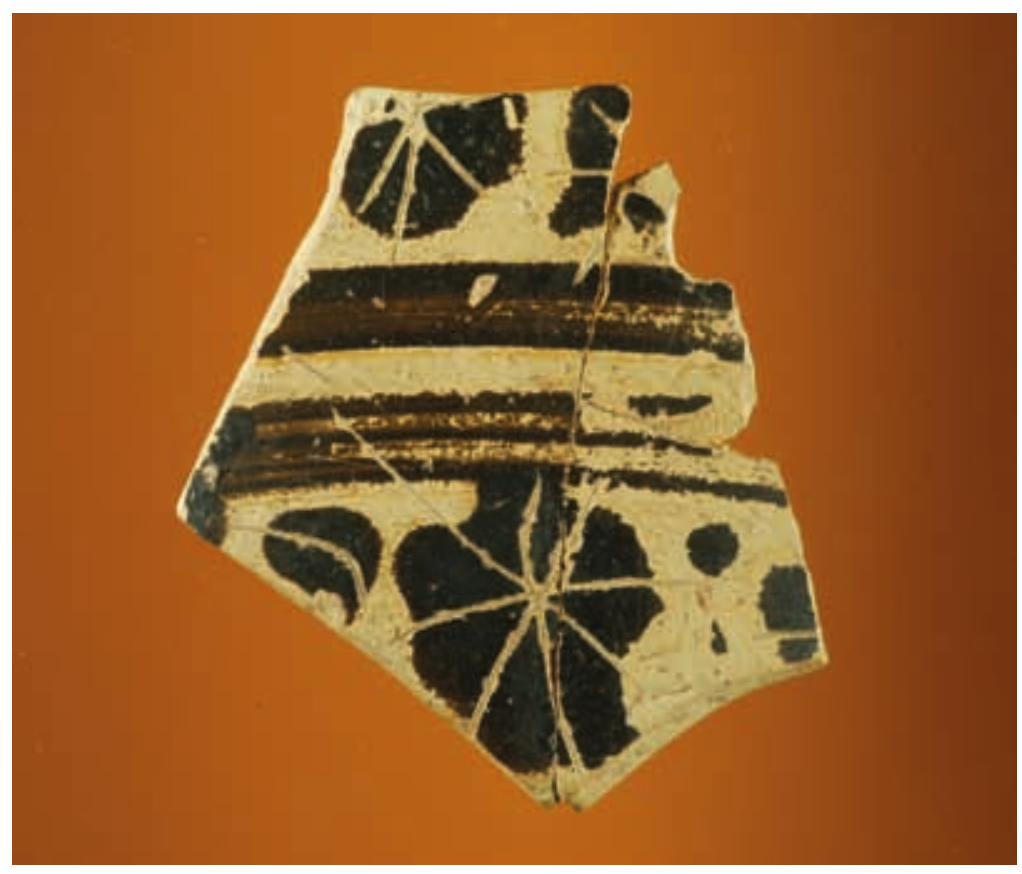

Fig. 7 - Fragmento de olpe de figuras negras do Coríntio Médio (fotografia de Víctor S. Gonçalves).

século VI a.n.e. (Arruda et al. 2013). Concretamente no que aos materiais diz respeito, registe-se a presença de ânforas de tipo R1, mais concretamente 10.1.2.1 de Ramón Torres (1995), de pratos, tigelas e taças de cerâmica de engobe vermelho e cinzenta, pithoi e "urnas" de tipo Cruz del Negro, pintados em bandas e de fíbulas de tipo Achebuchal (Arruda - Freitas 2008).

\section{Catálogo}

MAR/000- C. Mar. 2001 Sector 01 [0249] 3780.Fragmento de parede. A superfície interna em reserva. Figuras negras na superfície externa incorporadas em dois frisos, separados entre si linhas horizontais negras e vermelhas. Os contornos gerais das rosetas e das folhas estão marcados por finos traços incisos, que ultrapassam os seus próprios limites da própria roseta. Outros elementos decorativos, obtidos através da mesma técnica, estão igualmente presentes, tratando-se de simples pontos e de outras formas irregulares, trapezoidais ou semicirculares. No friso superior, é visível a pata de um quadrúpede. Bibliografia: Arruda 2007c: 144.

\subsection{A época clássica}

\subsubsection{Os vasos de figuras vermelhas}

\subsubsection{As kilikes}

A grande maioria dos fragmentos de vasos áticos decorados com figuras vermelhas corresponde a kilikes, com pé baixo, que datam, sobretudo do século IV a.n.e. (37 exemplares, 22 indivíduos), havendo dois cuja cronologia deve recuar para o final da centúria anterior.

Trata-se de taças com curvatura contínua no exterior, possuindo, as do século IV a.n.e., um ressalto na separação do corpo com o fundo interno, que marca, igualmente, o medalhão central, decorado. 

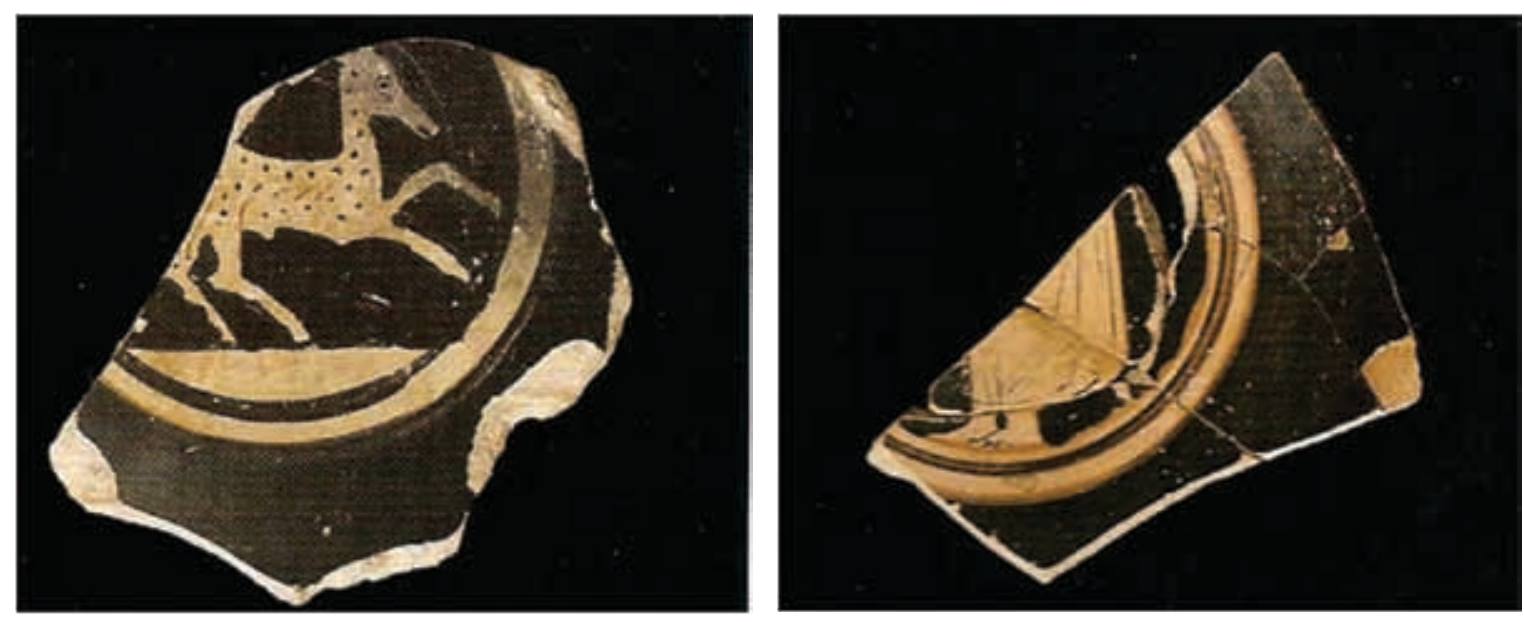

Fig. 8 - Kilikes de cerâmica ática de figuras vermelhas (pintor de Marlay ?) do século V a.n.e. (fotografias de Víctor S. Gonçalves).

As que datamos dos últimos anos do século V a.n.e. podem ser associadas às obras do "Círculo do Pintor de Marlay" (ARV2: 1276-82), como já foi anteriormente proposto (Arruda, 1997, 2007C). Ambos estão decorados no fundo interno, em medalhão central limitado por um ou dois círculos reservados. Num, é visível um cervídeo, em posição de salto, repousando as patas traseiras num exedro reservado (Arruda 1997) (MAR/002). O restante exibe parte do corpo e os pés de uma personagem masculina, envolta em himation (MAR/001). O fundo externo do primeiro está quase integralmente reservado, com excepção do círculo concêntrico e de um ponto central, ambos de verniz negro. Pelo contrário, no segundo, verifica-se banda, larga, de verniz negro, a que se segue uma outra, reservada. Em ambos casos, a superfície de apoio do pé não tem verniz aplicado. A atribuição a este pintor ou "círculo" foi baseada nas características tipológicas atribuídas às suas obras, destacando-se a representação de pés com pormenores anatómicos bem definidos, característica igualmente presente num dos exemplares do século V a.n.e. de Castelo de Castro Marim. Esta peça encontra paralelo, por exemplo, num fragmento identificado em Neapolis, datado de 425-400 a.n.e. (Trías 1967-1968), correspondendo igualmente a uma kylix de pé baixo, onde é percetível o mesmo detalhe na representação do pé de um jovem voltado para esquerda, envolto em um himation.

A escassez, no território actualmente português, de vasos gregos pintados desta cronologia justificará a ausência de outras obras de pintores incluídos neste "Círculo", que, contudo, estão, relativamente bem representadas na vizinha Espanha, sobretudo no SE e na Catalunha. Ainda assim, os motivos não têm, que conheçamos, paralelo nas obras destes artistas, pelo menos na Península Ibérica, se exceptuarmos o caso do veado do depósito de Zacatín, Granada, que decora também o fundo interno de uma taça de pé baixo (Rouillard - Torre Castellano - Sanchez Moreno 2017: fig. 11). No caso granadino, porém, o animal, que também se vira para a direita, está estático, havendo apenas uma linha de pontos sobre o dorso. Atendendo à decoração da superfície externa, dois jovens frente a frente envolvidos em manto, foi proposta a atribuição desta kylix ao Grupo do Pintor de Viena 116 (Ibidem: 279), datando-se, portanto, do século IV a.n.e. Como lembram os investigadores que estudaram as peças do depósito de Zacatín, os cervídeos isolados não são frequentes em kilikes, estando presentes, que se saiba, apenas em askoi, entre 450-400 a.n.e. (Ibidem: 286).

As taças do século IV são muito mais numerosas (35 fragmentos - 20 indivíduos) e quatro delas (MAR/003-MAR/006), em que a pintura conservada permitiu uma leitura mais completa, englobam- 

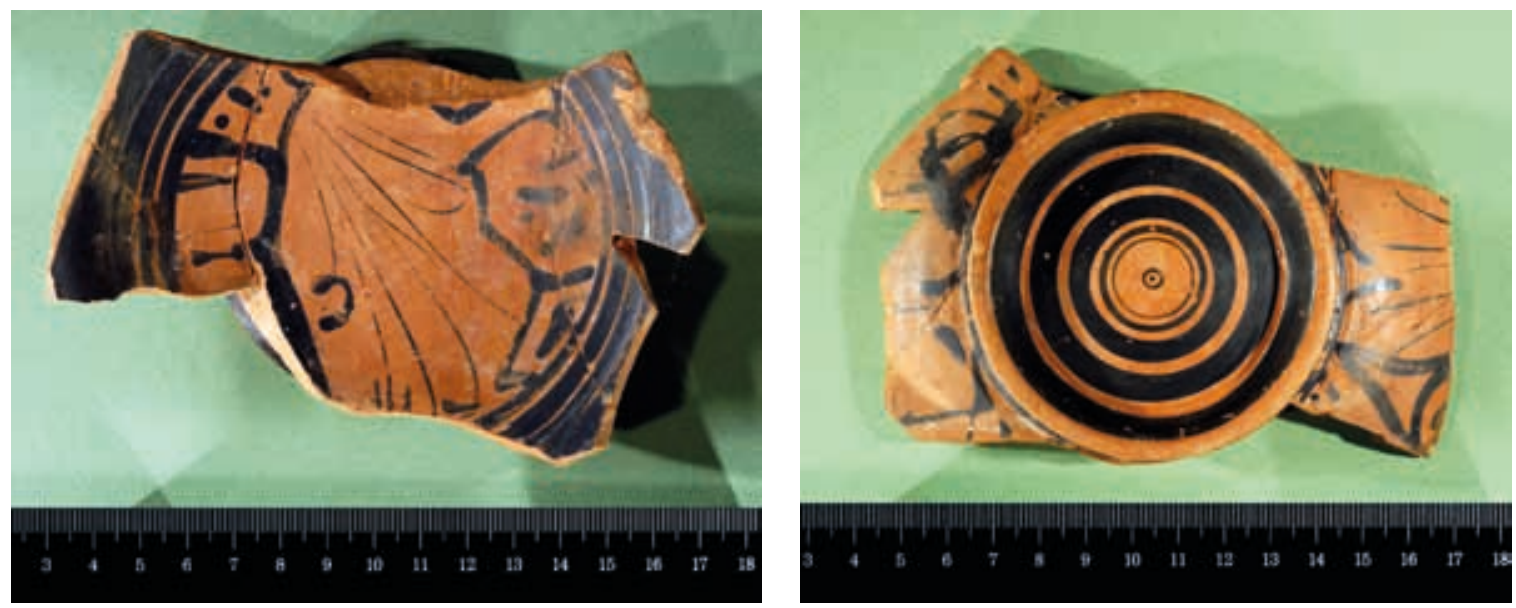

Fig. 9 - Kylikes de cerâmica ática de figuras vermelhas (pintor de Viena 116) do século IV a.n.e. (fotografias de Víctor S. Gonçalves).

se, seguramente, no Grupo do Pintor de Viena 116 (ARV2:1406). Outros quatro (MAR/007-MAR/010) puderam ser ainda incluídos neste mesmo grupo, ainda que com algumas reservas. Ainda assim, nestes últimos casos, e dada a reduzida dimensão da grande maioria, a classificação de boa parte deve ter em consideração a proximidade entre as obras deste Grupo e as que Beazley considerou do Grupo YZ - Pintor de Viena 155, Pintor de Viena 202 (ARV2: 1522-1525), e mesmo do Grupo de Bruxelas A 156, como aliás o investigador inglês teve o cuidado de deixar claro (ARV2: 1526; 1528). Jovens envolvidos nos seus mantos, virados para a direita e com o braço estendido decoram as superfícies internas, estando as externas preenchidas com volutas e palmetas.

As taças decoradas pelos artistas do Grupo do Pintor de Viena 116 são as mais difundidas na Península Ibérica (Trías 1967-1968; Rouillard 1975, 1991), sobretudo na Andaluzia, acompanhando, geralmente, os skyphoi do Grupo Fat Boy e os krateres do Grupo de Telos. A apresentação exaustiva de paralelos para as peças de Castro Marim torna-se, portanto, excessiva no contexto deste trabalho, mas parece importante recordar que, no actual território português, este pintor é, praticamente, exclusivo nas kilikes do século IV a.n.e. (Arruda 2007c). Ainda assim, são exactamente os paralelos que permitem avançar para as peças do sítio algarvio uma cronologia do segundo quartel do século IV a.n.e., tendo em consideração os dados recuperados no naufrágio de El Sec (Arribas et al. 1987), na necrópole de Baza (Presedo Velo 1982) e, mais recentemente, no depósito de Zacatín (Rouillard et al. 2017).

A kylix mais completa (MAR/004, $\left.\mathrm{n}^{\circ} 10046\right)$ permite ir um pouco mais longe na análise. Apresenta ressalto na parede interna a marcar o fundo, e a personagem, envolta em himatio, com $\mathrm{C}$ invertido na metade inferior esquerda, está virada para a direita e tem o braço estendido. A sua esquerda é visível uma aedicula. À direita, traços de verniz estão pintados sobre duas áreas reservadas e separadas entre si, que não sabemos classificar com precisão. No exterior, são visíveis restos de volutas e palmetas e ainda traços verticais que correspondem, certamente, a mantos das personagens que decorariam esta taça em particular. Não restam grandes dúvidas sobre a inclusão desta peça no Grupo do Pintor de Viena 116, com paralelo muito próximo, por exemplo em Turim (CVA III, I 9; BA 8030). Porém, tudo indica que incorporaria um "lote" distinto dos que foram identificados em Zacatín, em el Sec, e em Baza, eles próprios diferentes entre si. Recordese que este conceito, recentemente criado (Rouillard et al. 2017), associa forma, iconografia, organização e composição, tendo permitido verificar que o mesmo atelier (ou grupo) pode ter criado vários "lotes" distintos, partilhando as peças dos mesmos características idênticas. 


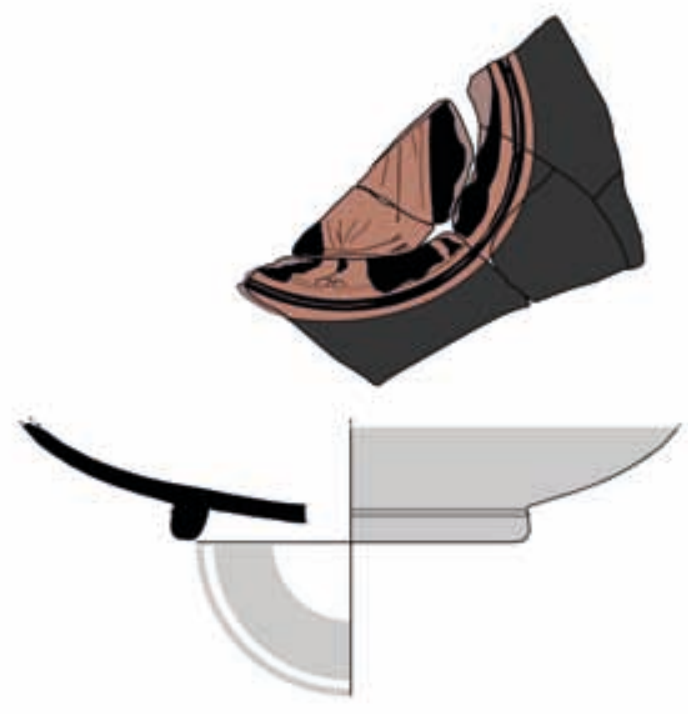

MAR/001
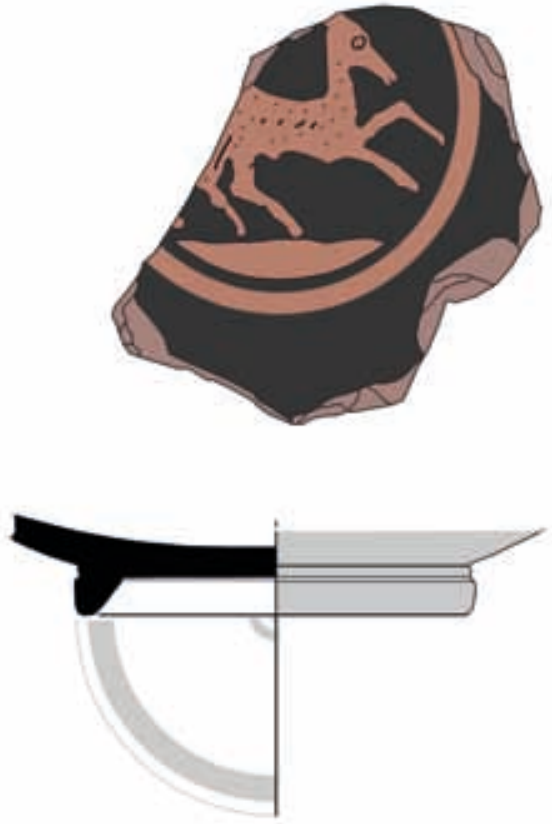

MAR/002

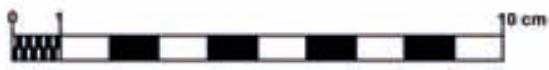

Fig. 10 - Kilikes de cerâmica ática de figuras vermelhas (pintor de Marlay ?) do século V a.n.e.

Vinte sete fragmentos de kilikes também pintados são de muito reduzida dimensão, sendo visíveis apenas traços que não permitem identificar os motivos com segurança (MAR/011-037). Alguns destes poderiam incluir-se ainda no Grupo de Viena 116, até porque, em alguns casos, nomeadamente em MAR/012, o fundo interno é destacado através de ressalto, característica habitual num dos "lotes" deste grupo de artistas (Rouillard et al. 2017). Todavia, e por precaução, não se assume, neste trabalho, esta identificação de forma definitiva.

Um outro fragmento composto por parte da parede e do fundo de uma taça está decorado em ambas as superfícies (MAR/017). O motivo representado na face externa é indeterminado, mas, na interna, é visível a cabeça de uma figura masculina, o que indicia que o medalhão central poderia estar integralmente preenchido por um jovem em uma cena de palestra. Os traços que definem esta personagem não se enquadram no "Grupo Viena 116", como fica claro pela forma como está representado o olho e mesmo o cabelo. As mesmas características estão presentes em kilikes andaluzas do século IV a.n.e., por exemplo em Castellon del Ceal (Trías 1967-1968: 479, lámina $(C X L)$.

As taças pintadas com figuras vermelhas do Castelo de Castro Marim foram recuperadas em níveis específicos, alguns dos quais conservados, o que lhes fornece uma posição contextual que importa aqui destacar.

Ambos os fragmentos do Círculo do Pintor de Marlay foram recuperados em níveis conservados da Idade do Ferro. O primeiro (MAR/001), datado intrinsecamente da segunda metade do século $\checkmark$ a.n.e., foi recolhido na U.E. [0773], que corresponde a um estrato de aterro pertencente à fase construtiva do depósito [0089], pelo que se pode assumir uma cronologia próxima da que foi proposta para este último, duas últimas décadas do século $V$ a.n.e. A outra (MAR/002) estava 


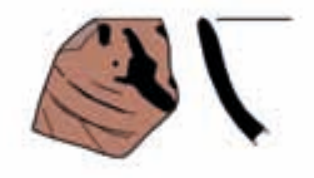

MAR/003
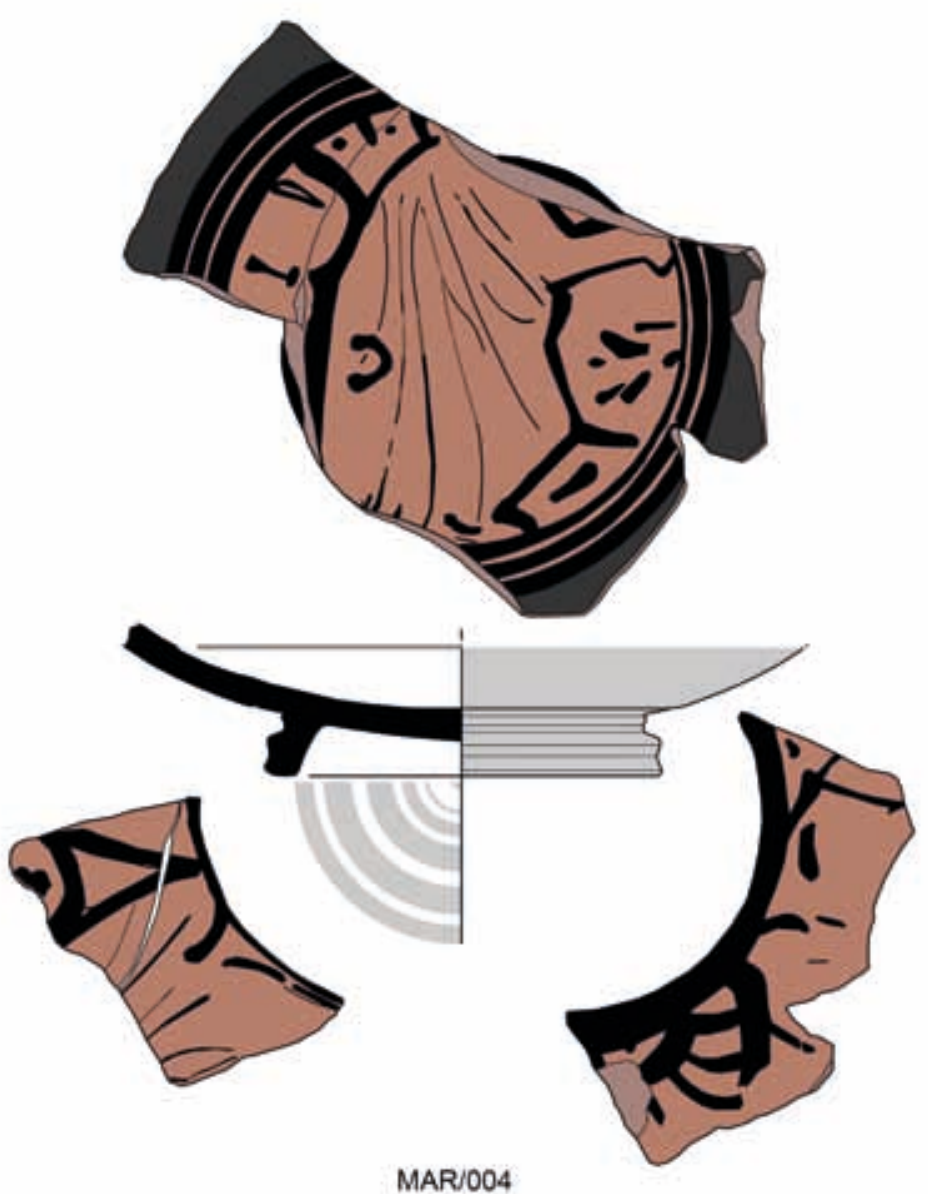

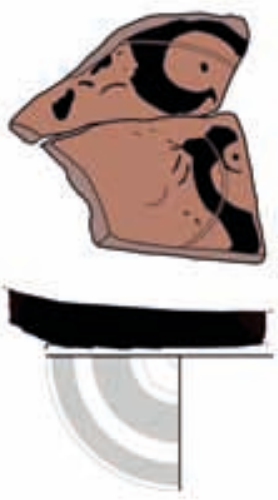

MAR/005

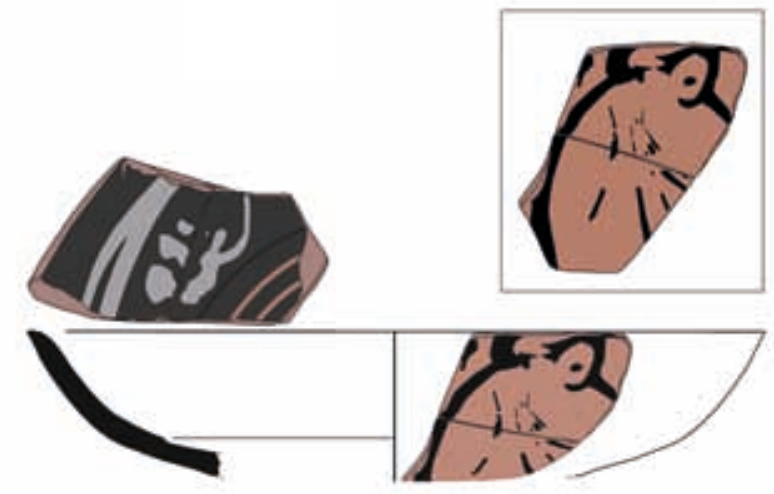

MARJ006

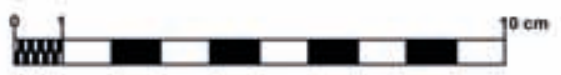

Fig. 11 - Kilikes de cerâmica ática de figuras vermelhas (pintor de Viena 116) do século IV a.n.e. 

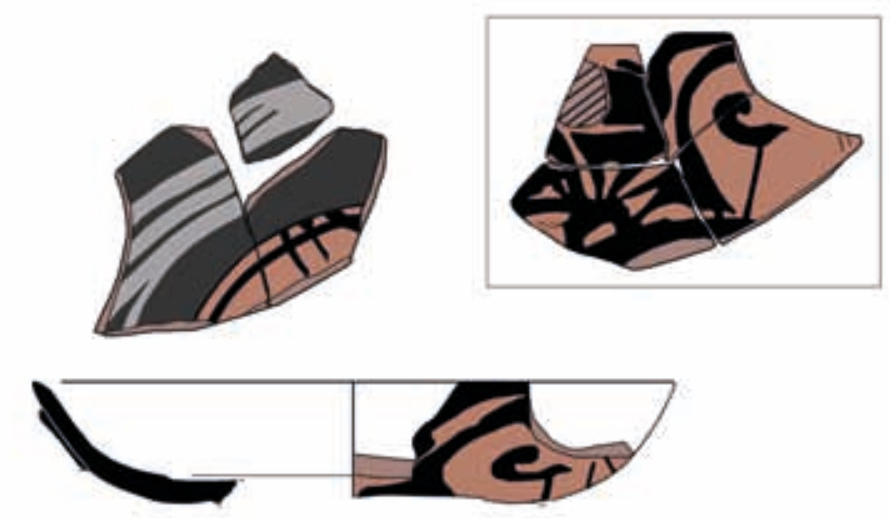

MAR/007
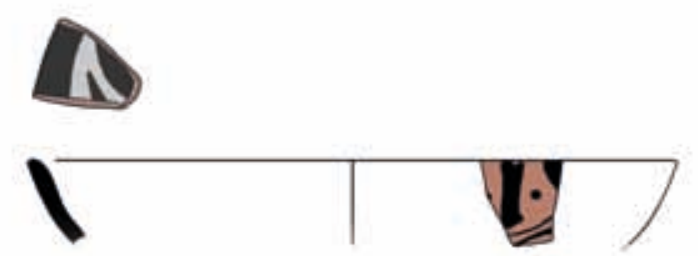

MAR/008

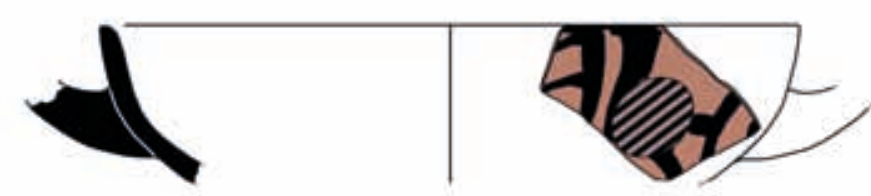

MAR/009
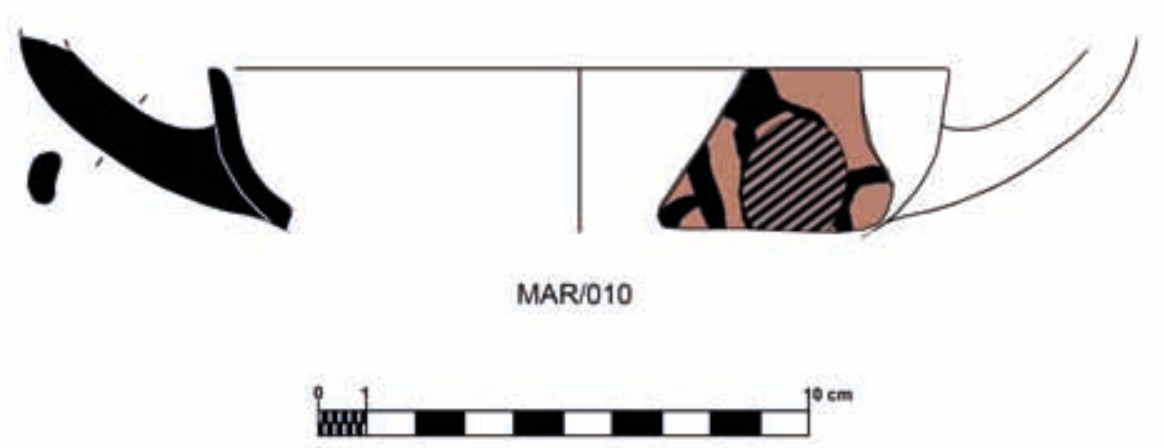

Fig. 12 - Kilikes de cerâmica ática de figuras vermelhas do século IV a.n.e. 


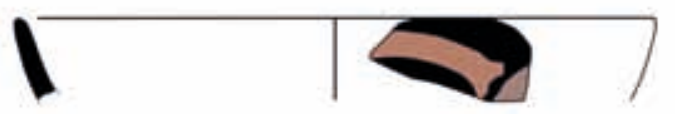

MAR/011

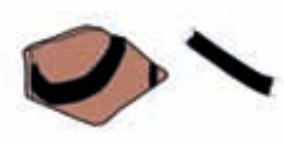

MAR/013

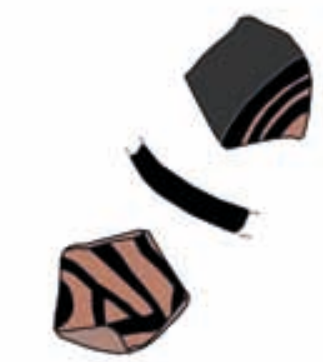

MAR/015

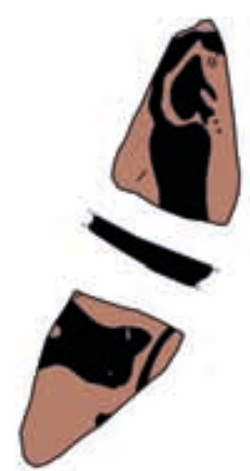

MAR/017

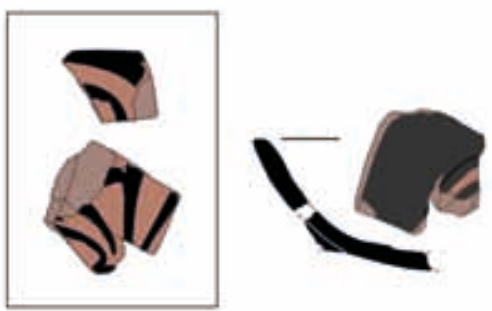

MAR/012

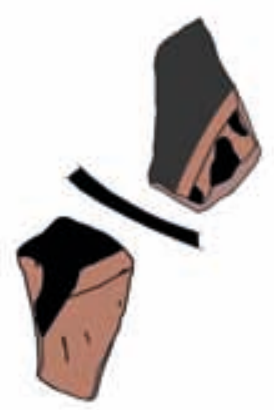

MAR/014

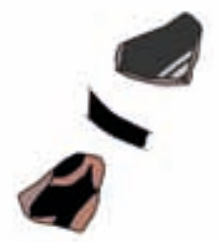

MAR/016

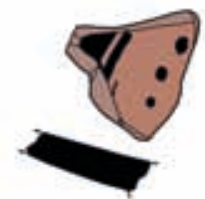

MAR/018

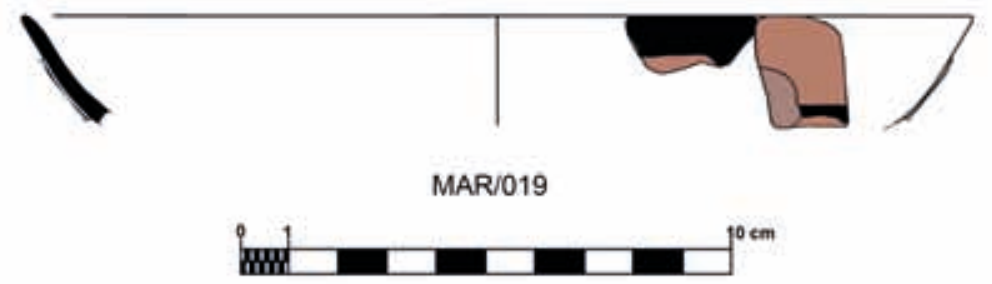

Fig. 13 - Kilikes de cerâmica ática de figuras vermelhas do século IV a.n.e. 

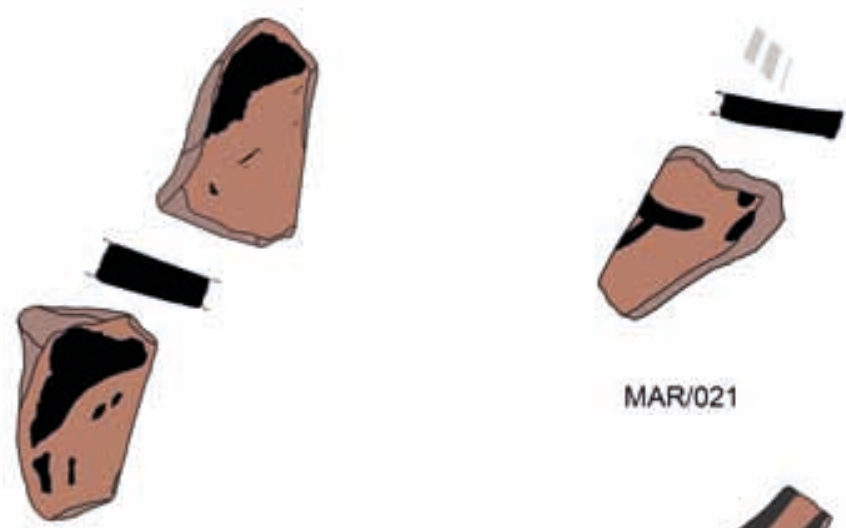

MAR/021

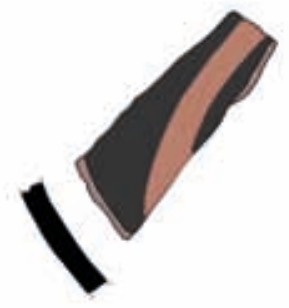

MAR/024

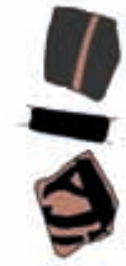

MAR/026

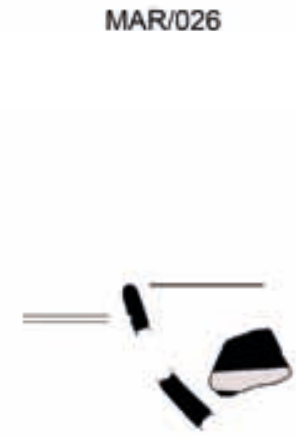

MAR/029

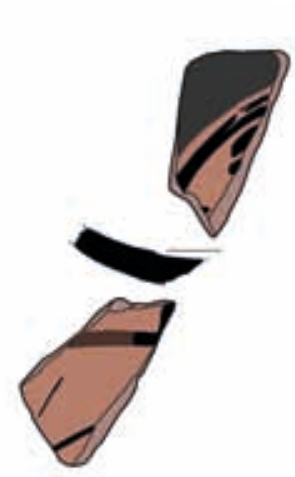

MAR/027

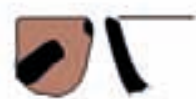

MAR/030

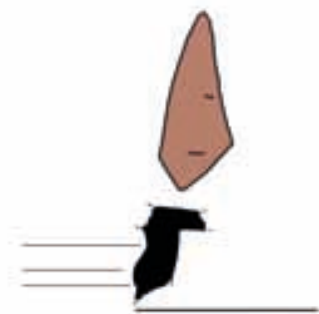

MAR/032

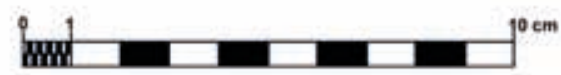

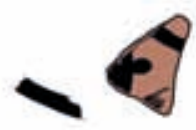

MAR/022

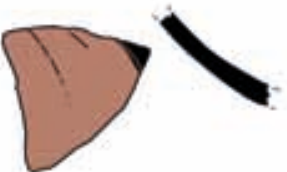

MAR/025

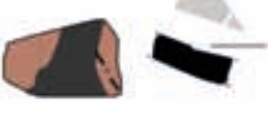

MAR/028

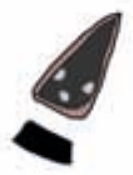

MAR/031

Fig. 14 - Kilikes de cerâmica ática de figuras vermelhas do século IV a.n.e. 
acompanhada, no Quadrado G 03 - Nível 03, por outro fragmento indeterminado de figuras vermelhas (MAR/046) e ainda por materiais de categorias diversas, concretamente de ânforas de tipo $B / C$ de Pellicer, parecendo portanto possível atribuir-lhe uma datação centrada também nas últimas duas décadas do século $V$ a.n.e.

Dos quatro fragmentos seguramente atribuíveis ao Pintor de Viena 116, apenas dois são provenientes de níveis conservados (MAR/004 e MAR/005). Um deles (MAR/004) foi recuperado em um estrato de aterro (U.E. [0535]), e encontrava-se associado a um fragmento de uma taça Cástulo (MAR/068), que poderá ser residual neste contexto. O outro (MAR/005) surgiu num estrato de entulhamento (U.E. [0545/0578]) que serviu de preparação para a construção de um pavimento, estando associado a um fundo de uma stemless cup (MAR/128) e a um fundo de cerâmica ática de figuras vermelhas (MAR/044).

Apenas um (MAR/007) dos quatro fragmentos que poderão pertencer ao Grupo do Pintor de Viena 116 (MAR/007 a MAR/010) foi exumado num nível de derrube / entulhamento da Idade do Ferro (U.E. [0593]), estando associado a um fragmento de cerâmica ática de verniz negro da forma Lamboglia 21/22 (MAR/177) e a ânforas do tipo Pellicer B/C.

Alguns fragmentos do século IV a.n.e. (Grupo do Pintor de Viena e pintor indeterminado) foram encontrados sem contexto primário, em níveis revolvidos modernos, medievais e romanos. Sete, porém, surgiram em estratos indubitavelmente da Idade do Ferro, como é o caso do MAR/012, recolhido na U.E. [0090], um nível de derrube/entulhamento, estando aqui associado a uma ânfora de tipo Maña Pascual A4 (variante 11.2.1.3 de Ramon Torres). Outro (MAR/019) é proveniente da U.E. [0650], correspondente a um pavimento, sendo de destacar a sua associação a um prato de peixe de cerâmica ática de verniz negro (MAR/206) e a uma ânfora do tipo Pellicer B/C.

Um terceiro fragmento (MAR/021) foi recolhido num estrato de derrube/entulhamento (U.E. [0518]), em associação a um outro de cerâmica ática de figuras vermelhas (MAR/033), que poderá corresponder, eventualmente, à mesma peça.

No caso da peça MAR/031, exumada no Quadrado E 02, Nível 04, cabe destacar a sua associação a um fragmento de cerâmica ática de verniz negro da forma Lamboglia 22 (MAR/169), mas também a cerâmica de tipo Kuass, ânforas do tipo Tiñosa (Ramon Torres 8.1.1.2) e Pellicer D, que apontam para uma cronologia um pouco mais tardia, necessariamente posterior ao terceiro quartel do século IV a.n.e.

Destaque merece também a peça MAR/034, proveniente da U.E. [0078], à qual se atribuiu equivalência com outras camadas do depósito [0089], que poderá corresponder, ainda que com algumas reservas, a um fragmento de cerâmica ática de figuras vermelhas. Se este for o caso, teria de tratar-se de uma produção mais antiga que as restantes (eventualmente contemporânea das produções do pintor de Marlay, já documentadas no sítio), considerando que a cronologia atribuída a estes contextos não ultrapassa os finais do século $V$ a.n.e.

Por último, resta referir a peça MAR/036, proveniente de uma camada de aterro da Idade do Ferro (U.E. [0756]), mas que não proporcionou outros materiais para além de um fragmento de um artefacto de pasta vítrea.

\section{Catálogo}

\section{CÍRCULO DO PINTOR DE MARLAY}

MAR/001 - C. Mar. 2003 Sector 01 [0773] 10202. Fragmento de parede, pé e fundo. Pé anelar e moldurado. A superfície interna apresenta um medalhão central decorado com figura humana envolta em himation, de que são visíveis as pregas correspondentes. Foi dado particular destaque 
aos pormenores anatómicos dos pés da figura, que se posicionam sobre área sobrelevada. A delimitar o medalhão central foram representados dois círculos concêntricos em reserva, alternados com círculo de verniz negro. O fundo externo apresenta-se reservado, complementado por um círculo concêntrico de verniz negro. A superfície de apoio do pé foi igualmente deixada em reserva. Os marcadores decorativos assemelham-se à obra do círculo do Pintor de Marlay. Pasta de cor laranja, dura, compacta e depurada. Verniz negro, aderente, espesso e brilhante. Diâmetro do pé: 6,6 cm. Bibliografia: Arruda 2007c: 144, fig. 71.

MAR/002 - C. Mar. 1984 Corte 01 Quadrado G 03 Nível 3 0010. Fragmento de parede, fundo e pé. Pé anelar e moldurado. Apresenta decoração no fundo interno composta por cervídeo em posição de salto, limitada por círculo reservado. Apresenta a superfície de apoio do pé em reserva, assim como o fundo externo, complementado por círculo concêntrico e ponto central em verniz negro. Apresenta semelhanças com a obra do círculo do Pintor de Marlay, ainda que a ausência de paralelos seguros para a iconografia desta peça não permita confirmar a associação ao supracitado pintor. Pasta rosada, dura, compacta e depurada. Verniz negro, aderente, espesso e brilhante. Diâmetro do pé: 8,2 cm. Espessura: 0,55 cm. Bibliografia: Arruda 1997: 120, fig. 1:1; Arruda 2007c: 144, fig. 70 .

\section{GRUPO DO PINTOR DE VIENA 116}

MAR/003 - C. Mar. 1986 Corte 01 Quadrado E 05 / B5 Sem nível 3362. Fragmento de bordo e parede. Lábio recto, estreitado na face interna. A superfície externa exibe decoração composta por uma figura masculina envolta em himation. O ponto negro, junto à boca, é traço característico dos trabalhos do Grupo de Pintor de Viena 116. Em frente da figura, existe um motivo indeterminado, possivelmente parte de um disco, dada a recorrência deste elemento nas obras do grupo deste pintor. Pasta de cor bege, dura, compacta e depurada. Verniz de cor cinzenta, na superfície interior, e negra na face exterior. O verniz é aderente e pouco espesso. Espessura máx.: 0,36 cm.

MAR/004 - C. Mar. 2003 Sector 01 [0535] 10046. Fragmento de parede, fundo e pé. Pé anelar e moldurado. A parede apresenta um ressalto na superfície interna, a marcar o arranque do fundo. Na superfície interna foi representado um jovem envolto em himation. Esta personagem central encontra-se voltada para a direita e tem o braço estendido. O himation apresenta traços de diferentes espessuras a marcar as suas pregas e, entre elas, um motivo em forma de «C» invertido, desenhado com traço mais espesso. À esquerda da cabeça do jovem foi representado um «disco» de forma trapezoidal, com meia haste e dois pontos inscritos. Por baixo consta um elemento arquitetónico indeterminado. O medalhão central encontra-se delimitado por três círculos concêntricos reservados e de verniz negro, alternados. Em frente do jovem, foram representados motivos indeterminados, sendo possível que se trate de um altar, elemento frequente em peças semelhantes do Grupo do Pintor de Vienna 116. A zona da cabeça encontra-se fraturada. Na superfície externa conservam-se vestígios de uma palmeta, parte de uma voluta, vestígios de um manto e motivos indeterminados, que poderão corresponder ao manto de uma segunda figura. $\mathrm{O}$ fundo externo exibe círculos reservados e em verniz negro, alternados. Pasta de cor laranja, dura, compacta e depurada. Verniz negro, aderente, espesso e brilhante. Grupo do pintor de Viena 116. Diâmetro do pé: 7,9 cm. Bibliografia: Arruda 2007c: 144, fig. 72.

MAR/005 - C. Mar. 2002 Sector 01 [0545] 6055; C. Mar. 2002 Sector 01 [0578] 15595. Fragmento de fundo. A superfície interna apresenta decoração composta de jovem envolto em himation, 
voltado à direita. Apresenta o braço esticado e, sobre ele, vestígios de disco com pontos inscritos. A decoração encontra-se muito deteriorada sendo possível, no entanto, distinguir vestígios das pregas das vestes; a mancha correspondente ao cabelo; o olho e o que parece ser um ponto na face, elemento característico das obras do Grupo do Pintor de Viena 116. A superfície externa do fundo apresenta-se escalonada e exibe decoração composta de círculos reservados e em verniz negro, alternados. Espessura: $0,7 \mathrm{~cm}$.

MAR/006 - C. Mar. 2002 Sector 01 [0360] 3972. Dois Fragmentos com colagem entre si correspondendo a bordo e parede. Lábio recto, estreitado na face interna. A superfície externa exibe decoração composta por uma figura masculina envolta em himation. $O$ ponto negro, junto à boca, é traço característico dos trabalhos do Grupo de Pintor de Viena 116. Em frente e atrás da figura, existem vestígios de motivos indeterminados. A superfície interna apresenta-se decorada com possíveis motivos vegetais e dois círculos reservados a marcar o arranque do fundo. Pasta de cor laranja, dura, compacta e depurada. Verniz de cor negra, na superfície interior, e negra na face exterior. $O$ verniz é aderente, espesso e brilhante. Espessura máx.: $0,5 \mathrm{~cm}$.

\section{Possível GRUPO DO PINTOR DE VIENA 116}

MAR/007 - C. Mar. 2002 Sector 01 [0593] 6086; C. Mar. 2002 Sector 01 [0593] 15593. Quatro fragmentos com colagem entre si, correspondendo a bordo, parede e arranque de asa. Lábio recto, estreitado na face interior. A superfície interna apresenta-se decorada com motivos vegetais, possivelmente talos, representados entre o bordo e o ressalto que marca o arranque do fundo. O medalhão central é delimitado por um círculo concêntrico em verniz negro, parcialmente associado a um motivo decorativo indeterminado. A superfície externa exibe vestígios de uma palmeta, uma voluta vertical e de um possível manto. Com possíveis paralelos em obras do Grupo do pintor de Viena 116 (?). Pasta de cor laranja, dura, compacta e depurada. Verniz negro, aderente, espesso e brilhante. Diâmetro de bordo: $13,5 \mathrm{~cm}$.

MAR/008 - C. Mar. 2002 Sector 01 [0526] 6092. Fragmento de bordo e parede. Lábio recto, de perfil tendencialmente oval. Apresenta decoração na superfície externa composta de vestígios de disco de meia haste e dois pontos inscritos, motivo frequentemente associado ao Grupo do Pintor Viena 116. Na superfície interna exibe elemento a cor cinzenta, sobrepintado, correspondendo provavelmente a um motivo vegetal (talos?). Pasta de cor laranja, dura, compacta e depurada. Verniz negro, aderente, espesso e brilhante. Diâmetro de bordo: 13,17 cm.

MAR/009 - C. Mar. 2002 Sector 01 [0606] 10131. Fragmento de bordo, parede e asa. Lábio recto, ligeiramente estreitado na face interna. A asa encontra-se fracturada na extremidade. A superfície externa apresenta decoração composta de vestígios de palmeta e voluta. Com possíveis paralelos em obras do Grupo do Pintor de Viena 116. Pasta de cor laranja, dura, compacta e depurada. Verniz negro, aderente, espesso e brilhante. Diâmetro de bordo: 14,2 cm. Bibliografia: Arruda 2007c: 144, fig. 73.

MAR/010 - C. Mar. 2003 Sector 01 [0584/0626] 10135. Fragmento de bordo, parede e asa. Lábio recto, ligeiramente estreitado na face interna. A asa encontra-se fracturada na extremidade. A superfície externa é decorada com vestígios de palmeta e possível voluta. Com possíveis paralelos em obras do Grupo do Pintor de Viena 116. Pasta de cor bege e tonalidade alaranjada, dura, compacta e depurada. Verniz negro, aderente, espesso e brilhante. Diâmetro de bordo: $15,03 \mathrm{~cm}$. 


\section{PINTOR INDETERMINADO}

MAR/011 - C. Mar. 2002 Sector 01 [Sup.] 6255. Fragmento de bordo e parede. Lábio recto, de perfil oval. A superfície externa apresenta motivo decorativo que poderá corresponder a vestígio de uma voluta vertical. Pasta de cor laranja, dura, compacta e depurada. Verniz negro, aderente, espesso e brilhante. Diâmetro de bordo: $13 \mathrm{~cm}$.

MAR/012 - C. Mar. 2000 Sector 01 [0090] 903. Fragmento de bordo, parede e arranque de asa. Lábio recto, de perfil oval. Apresenta motivo decorativo na superfície externa, podendo tratarse de vestígios de uma voluta vertical. A superfície interna apresenta um pequeno ressalto, que marca o início do fundo. Pasta de cor laranja, dura, compacta e depurada. Verniz negro, aderente, espesso e brilhante. Espessura máx.: 0,4 cm.

MAR/013 - C. Mar. 2002 Sector 01 [0526] 6088. Fragmento de parede. A superfície externa apresenta decoração composta de vestígios de voluta. Pasta de cor bege e tonalidade alaranjado, dura, compacta e depurada. Verniz negro, aderente, espesso e muito brilhante. Espessura max.: $0,35 \mathrm{~cm}$.

MAR/014 - C. Mar. 1986 Corte 01 Quadrado D 03 Nível 04 2998. Fragmento de parede. A superfície externa apresenta-se decorada com vestígios da cabeça de um jovem, sendo percetível parte do cabelo. Exibe na superfície interna, vestígios de um possível manto e de um aryballos, que fariam parte do medalhão central limitado por ressalto. Pasta de cor laranja clara, dura, compacta e depurada. Verniz negro, aderente, espesso e pouco brilhante. Espessura 0,25 cm. Bibliografia: Arruda 1997: 120, fig. 1: 2.

MAR/015 - C. Mar. Sup. sem n..$^{\circ}$ 01. Fragmento de parede e arranque de fundo. A superfície interna apresenta decoração composta de círculos reservados e em verniz negro, alternados, a delimitar o medalhão central. A superfície exterior exibe decoração composta de vestígios de uma palmeta. Pasta de cor laranja, dura, compacta e depurada. Verniz negro, aderente, espesso e muito brilhante. Espessura max.: 0,5 cm.

MAR/016 - C. Mar. 2002 Sector 01 [0360] 3973. Fragmento de parede. A superfície interna exibe decoração composta de dois círculos concêntricos de cor cinzenta, sobrepintados. Apresenta motivo indeterminado na superfície externa, podendo corresponder a vestígio de uma espiral ou parte do cabelo de um jovem. Pasta de cor laranja, dura, compacta e depurada. Verniz negro, aderente, espesso e brilhante. Espessura máx.: 0,4 cm.

MAR/017 - C. Mar. 2002 Sector 01 [0526] 6043. Fragmento de parede. Apresenta decoração na superfície exterior e interior. Na face interior, é percetível uma figura masculina. Na superfície exterior exibe motivo indeterminado. Pasta de cor laranja, dura, compacta e depurada. Verniz negro, aderente, espesso, de boa qualidade. Espessura: 0,3-0,5 cm.

MAR/018 - C. Mar. 2002 Sector 01 [0389] 5840. Fragmento de parede e arranque de fundo. A superfície externa apresenta-se totalmente engobada. A face interna exibe decoração composta de círculo concêntrico a delimitar um medalhão central e três pontos a sobrepintados a negro. Pasta de cor laranja clara, dura, compacta e depurada. Verniz negro, aderente, espesso e brilhante. 
MAR/019 - C. Mar. 2003 Sector 01 [0650] 10141. Fragmento de bordo, parede e arranque de asa. Na superfície externa apresenta motivo decorativo indeterminado. Pasta de cor laranja, dura, compacta e pouco depurada. Verniz negro com manchas avermelhadas, aderente e pouco espesso. Diâmetro de bordo: 19,4 cm.

MAR/020 - C. Mar. 2000 Sector 01 [Sup.] 1066. Fragmento de fundo e arranque de parede. A superfície interna do fundo apresenta motivo indeterminado, correspondendo possivelmente a vestígios de um manto. O fundo externo exibe círculos em verniz negro e em reserva, alternados. Pasta de cor bege, dura, compacta e depurada. Verniz muito deteriorado, negro, aderente, espesso e brilhante. Espessura máx.: $0,8 \mathrm{~cm}$.

MAR/021 - C. Mar. 2002 Sector 01 [0518] 6065. Fragmento de fundo e arranque de parede. A superfície externa exibe decoração composta de motivos indeterminados. A face interna apresenta círculos em verniz negro e em reserva, alternados. Pasta de cor laranja, dura, compacta e depurada. Verniz negro, aderente, espesso e brilhante. Espessura máx.: 0,54 cm.

MAR/022 - C. Mar. 1984 Corte 01 Quadrado F 02 Sem nível 2837. Fragmento de parede. Apresenta decoração na superfície interna composta de motivos indeterminados. É possível que se trate da representação de um disco, conservando-se parte da haste e um dos pontos inscritos. Pasta de cor cinzenta e tonalidade esverdeada, dura, compacta e depurada. Verniz negro, espesso, aderente e baço. Espessura máx.: 0,4 cm. Bibliografia: Arruda 1997: 120.

MAR/023 - C. Mar. Sup. sem n. ${ }^{\circ}$ 02. Fragmento de parede e arranque de fundo. Exibe na superfície exterior três círculos concêntricos em reserva. Pasta de cor bege e tonalidade alaranjada, dura, compacta e pouco depurada. Verniz negro, aderente, espesso e brilhante. Não ilustrado. Espessura máx.: $0,78 \mathrm{~cm}$.

MAR/024 - C. Mar. 1983 Sup. 2783. Fragmento de parede. Apresenta na superfície interna decoração composta de um círculo concêntrico reservado a delimitar o medalhão central, desaparecido Pasta de cor laranja claro, dura, compacta e depurada. Verniz negro de tonalidade acinzentada, pouco aderente, pouco espesso e baço. Bibliografia: Arruda 1997: 120, fig. 1: 3.

MAR/025 - C. Mar. 2002 Sector 01 [0584] 6052. Fragmento de parede. A superfície externa apresenta-se decorada com possível vestígio de manto. Pasta laranja, dura, compacta e depurada. Verniz negro, aderente, espesso e brilhante. Espessura máx.: 0,4 cm.

MAR/026 - C. Mar. Sup. sem n. ${ }^{\circ}$ 03. Fragmento de pequena dimensão correspondendo a parede e arranque de fundo. A superfície interna apresenta círculo reservado, correspondendo possivelmente ao limite do medalhão central. A superfície externa exibe motivo indeterminado, podendo corresponder a vestígios de uma palmeta. Pasta de cor laranja, dura, compacta e depurada. Verniz negro, aderente, espesso e brilhante. Espessura máx.: 0,45 cm.

MAR/027 - C. Mar. Sup. sem n. ${ }^{\circ}$ 04. Fragmento de parede e arranque de fundo. A superfície externa apresenta vestígios de possível manto. A face interna exibe um círculo concêntrico reservado a delimitar medalhão central, sendo igualmente percetíveis motivos indeterminados. Pasta de cor laranja, compacta e depurada. Verniz negro, aderente, espesso e brilhante. Espessura máx.: 0,6 cm. 
MAR/028 - C. Mar. 1987 Corte 03 Quadrado C 05 Nível 01 2827. Fragmento de pequena dimensão correspondendo a parede e arranque do fundo. Exibe decoração na superfície externa composta de motivo indeterminado. A superfície interna apresenta linha reservada, possivelmente correspondendo ao limite do medalhão central. Pasta de cor laranja, dura, compacta e depurada. Verniz negro, aderente, pouco espesso na superfície externa e baço. Espessura: 0,4 cm. Bibliografia: Arruda 1997: 120.

MAR/029 - C. Mar. 2002 Sector 01 [0389] 5845. Fragmento de bordo e parede. Lábio recto, de perfil oval. A superfície externa apresenta-se totalmente engobada com canelura reservada imediatamente a seguir ao lábio. A superfície interna exibe banda com decoração indeterminada, sobrepintada a branco. Pasta de cor laranja, dura, compacta e depurada. Verniz negro, aderente, espesso e brilhante. Espessura máx. parede: $0,4 \mathrm{~cm}$.

MAR/030 - C. Mar. 1987 Corte 01 Quadrado E 04 Nível 03 3745. Fragmento de bordo e parede. Lábio recto, de perfil oval. Apresenta motivo decorativo indeterminado na superfície externa. Pasta de cor laranja, dura, compacta e depurada. Verniz negro, aderente pouco espesso e brilhante. Espessura máx.: 0,4 cm.

MAR/031 - C. Mar. 1986 Corte 01 Quadrado E 02 Nível 04 2834. Fragmento de parede de pequena dimensão. Pasta de cor laranja, dura compacta e depurada. Na superfície interna exibe motivo composto de três prontos representados a cor cinzenta, sobrepintados. Bibliografia: Arruda 1997: 120.

MAR/032 - C. Mar. Sup. sem n. ${ }^{\circ}$ 05. Fragmento de fundo, pé e arranque de parede. Pé alto e moldurado. A superfície interna do fundo é decorada com possível vestígio de manto. Pasta de cor laranja, dura, compacta e depurada. Verniz negro, muito deteriorado.

MAR/033 - C. Mar. 2002 Sector 01 [0518] 6067. Fragmento de parede. O avançado estado de deterioração do fragmento não permite confirmar que se trata de uma peça de figuras vermelhas. Não ilustrado.

MAR/034 - C. Mar. 2000 Sector 01 [0078] 900. Fragmento de parede. A superfície externa apresenta-se muito deteriorada, sendo possível que registasse decoração de figuras vermelhas, indeterminada. Não ilustrado.

MAR/035 - C. Mar. 1983 Sup. 0183. Fragmento de fundo de forma indeterminada. Pasta de cor laranja, dura, compacta e depurada. Verniz negro, pouco brilhante. A superfície externa apresenta-se muito deteriorada, sendo possível que registasse decoração de figuras vermelhas, indeterminada. Não ilustrado.

MAR/036 - C. Mar. 2003 Sector 01 [0756] 11705. Fragmento de parede. Pasta de cor bege, dura, compacta e depurada. Verniz negro, aderente, espesso e brilhante. A superfície externa apresenta-se muito deteriorada, sendo possível que registasse decoração de figuras vermelhas, indeterminada. Não ilustrado.

MAR/037 - C. Mar. 2002 Sector 01 [0385] 5915. Fragmento de parede. Pasta de cor bege, dura, compacta e depurada. Verniz negro. A superfície externa apresenta-se muito deteriorada, sendo possível que registasse decoração de figuras vermelhas, indeterminada. Não ilustrado. 


\subsubsection{Os skyphoi}

Os skyphoi pintados estão representados por apenas dois exemplares.

Do primeiro (MAR/038), conserva-se uma porção de bordo e de parede. A superfície externa está decorada com figuras vermelhas composta por uma grinalda de folhas de murta, em reserva, associada a ramagem sobre-pintada a branco. A área decorada está separada do corpo da peça através de uma linha também sobre-pintada a branco. A morfologia do bordo, recto, e a decoração indicam uma cronologia centrada no final do século $V$ a.n.e., tal como Marina Picazo e Pierre Rouillard tiveram oportunidade de demonstrar em 1976 para esta decoração em concreto, o que viria a ser confirmado, de forma definitiva, pelo conjunto de Cancho Roano (Gracía Alonso 2003: 33-34, 2005: 1187) o importante sítio extremenho que forneceu o maior conjunto peninsular de este tipo de skyphoi. Porém, e em termos gerais, este tipo de vaso pintado com figuras vermelhas não é muito abundante na Península Ibérica, destacando-se, para o território espanhol, o já citado Cancho Roano e os exemplares da necrópole de Castellones del Ceal (Trías 1967-1968: pl. CCXXXIX, 2) e do povoado de la Bienvenida (Fernández Ochoa - Caballero Klink 1988; Sanchez 1991), para além dos sítios do Levante peninsular, como são os casos de Ampúrias (Trías 1967-1968) e de Ullastreet (Picazzo 1977).

As características formais (bordo recto) e decorativas (folhas em reserva; ramagem sobrepintada) da peça de Castro Marim inserem-na no Grupo Aa definido por Picazo e Rouillard (1976: 14).

O skyphos algarvio foi recuperado na UE [0679], nível primário de ocupação, que ofereceu também uma taça ática de verniz negro da classe delicada (MAR/113), um fragmento de asa (MAR/295), e ânforas de tipo Pellicer B/C e Maná Pascual A4 (11.2.1.3. de Ramon Torres). A cronologia contextual compagina-se, portanto, com a que é tradicionalmente atribuída aos skyphoi decorados com grinalda de folhas de murta.

Mais tardio será o exemplar MAR/039, que, infelizmente, não possui contexto estratigráfico seguro. A superfície interna está integralmente coberta por verniz, e na externa há traços verticais e horizontais de espessura variada, que, contudo, não definem nenhuma gravura passível de ser lida com exactidão.

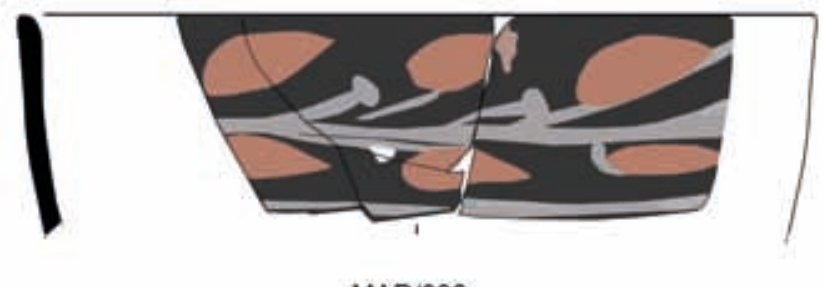

MAR/038

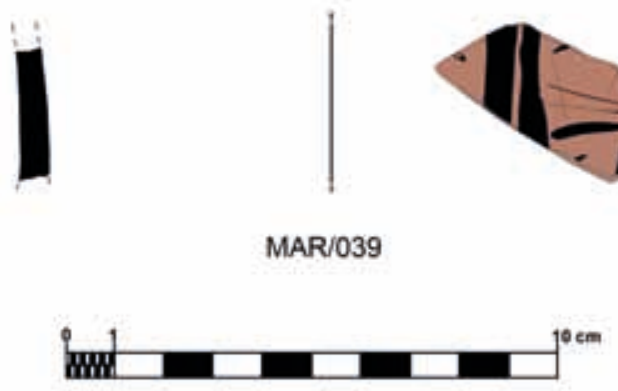

Fig. 15 - Skyphoi de cerâmica ática de figuras vermelhas do século V a.n.e. 


\section{Catálogo}

MAR/038 - C. Mar. 2002 Sector 01 [0679] 11711. Três fragmentos pertencentes à mesma peça, correspondendo a bordo e parede. Lábio recto, estreitado na face interna. Parede com curvatura pouco pronunciada. Exibe, na superfície interna, uma banda de cor cinzenta sobrepintada. $\mathrm{Na}$ superfície externa apresenta decoração composta de folhas de murta, associadas a rama de cor branca sobrepintada sob o verniz negro. Pasta de cor cinzenta e tonalidade bege, dura, compacta e depurada. Verniz de cor negra, com manchas avermelhadas na face interna. O verniz é aderente, brilhante e pouco espesso em determinadas áreas. Diâmetro: 16,19 cm.

MAR/039 - C. Mar. 2002 Sector 01 [0428] 5328. Fragmento de parede. Decorado na face externa com motivos indeterminados. A superfície interna apresenta-se integralmente coberta por verniz negro. Pasta de cor laranja clara, dura, compacta e depurada. Verniz negro, espesso, aderente e brilhante. Espessura máx.: 6,1 cm.

\subsubsection{As pelikai}

Dois fragmentos de reduzida dimensão foram classificados como pelikai, ainda que tal classificação se faça com as necessárias reservas. Em um deles (MAR/041), uma parede, é visível uma decoração, na superfície externa, composta por uma banda de óvulos, decoração muito frequente neste tipo de recipiente. A superfície interna está integralmente coberta por verniz negro. As características gerais, nomeadamente a espessura, a orientação e a própria decoração permitem admitir a possibilidade de se tratar de um vaso deste tipo, mas, e como já referimos, a classificação é problemática.

A asa, de fita e pouco espessa (MAR/040), levanta as mesmas dificuldades de integração morfológica, mesmo que admitamos que poderá pertencer também a uma pelike.

A forma não é, na Península Ibérica, particularmente frequente, sobretudo em ambientes de habitat.

Apenas um dos dois fragmentos de pelikai foi recolhido num nível conservado da Idade do Ferro (MAR/041). Trata-se de um pavimento de argila (U.E. [0035]), que proporcionou também ânforas do tipo Pellicer B/C e fragmentos indeterminados de cerâmica ática de verniz negro (MAR/240), mas também um fragmento de cerâmica de tipo Kuass. A construção deste pavimento pode ter ocorrido já no último quartel metade do século IV a.n.e., tendo sido utilizados materiais anteriores.

\section{Catálogo}

MAR/040 - C. Mar. 1987 Corte 03 Quadrado B 05 Nível 01 3739. Fragmento de asa em fita. Pasta de cor bege, dura, compacta e pouco depurada. Verniz negro, aderente, pouco espesso e brilhante.

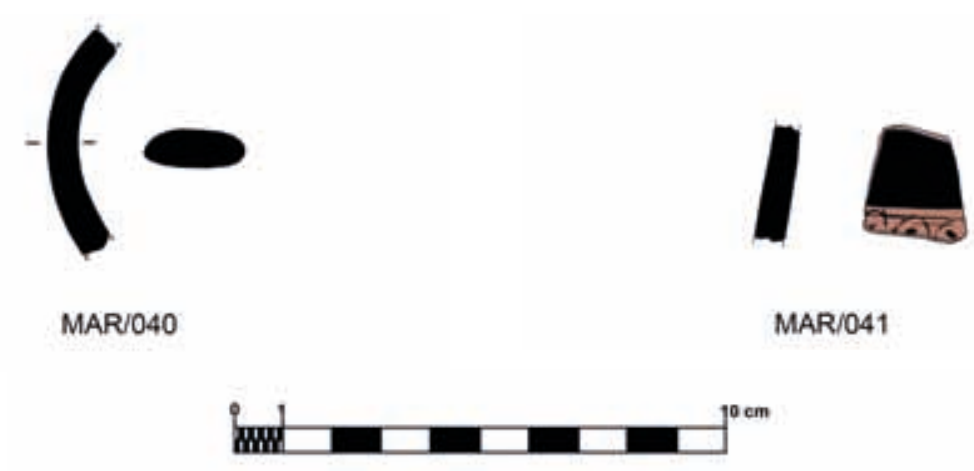

Fig. 16 - Pelikay de cerâmica ática de figuras vermelhas do século IV a.n.e. 
MAR/041 - C. Mar. 2000 Sector 01 [0035]769. Fragmento de parede. Exibe decoração composta de banda de óvulos na superfície exterior. Pasta de cor laranja, dura, compacta e depurada. Verniz negro, aderente, espesso, brilhante, muito deteriorado na face exterior. Espessura máx.: 0,63 cm.

\subsubsection{A lekythos aribalística}

Um fragmento de fundo, pé e parede (MAR/042) pode ser recolhido nesta forma, ainda que, dada a dimensão do fragmento, esta classificação não se assuma como completamente segura. O engobe é vermelho e os quatro pontos brancos sobre-pintados na superfície externa são tudo o que resta da sua decoração. A escassa dimensão do fragmento limita uma apreciação mais detalhada deste vaso, mas recordamos que a colocação de pontos brancos sobre-pintados em área reservada junto ao fundo é recorrente nesta forma, sobretudo nas peças em que a decoração do corpo é constituída por um, mais ou menos denso, reticulado.

As lekytoi aribalísticas são presença relativamente comum na Península Ibérica, mas sobretudo nos contextos sepulcrais da Andaluzia (Baza, Castellones de Ceal), do Sudeste (Los Nietos) e Nordeste (Ampúrias, Ullastret), quer os decorados com palmeta de figuras vermelhas, quer com os reticulados (Trías 1967-1968; Rouillard 1991). Habitualmente, ambas as versões, que são contemporâneas, acompanham os vasos de figuras vermelhas tardios, datando-se da primeira metade do século IV a.n.e. Como paralelos mais próximos, podemos ainda citar as duas peças de Tavira, uma delas com decoração reticulada, e ainda a de Faro (Barros 2005: 936; 941).

O exemplar de Castro Marim não possui informação contextual segura, uma vez que é proveniente de uma Unidade Estratigráfica revolvida, formada na época moderna, que contém materiais da Idade do Ferro, mas também romanos, republicanos e imperiais, e modernos.

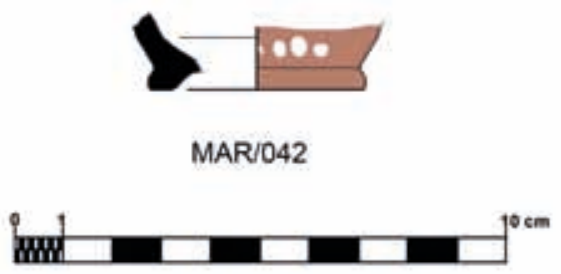

Fig. 17 - Lekythos aribalística de cerâmica ática de figuras vermelhas do século IV a.n.e.

\section{Catálogo}

MAR/042 - C. Mar. 2002 Sector 01 [0360] 5384. Fragmento de parede, fundo e pé. A face externa da parede é decorada com vestígios de quatro pontos sobrepintados a branco. Pasta de cor laranja clara e tonalidade rosa, dura, compacta e depurada. Verniz vermelho na superfície interior e exterior, ainda que nesta última se apresente praticamente desaparecido. Verniz aderente e pouco espesso. Diâmetro de pé: $4,4 \mathrm{~cm}$.

\subsubsection{Indeterminados}

Alguns fragmentos de muito reduzida dimensão, que, ainda assim, foram passíveis de integrar no grupo de vasos de cerâmica ática de figuras vermelhas, não puderam ser classificados quanto à forma. $\mathrm{O}$ artista que decorou esses mesmos vasos é, evidentemente, igualmente impossível de atribuir.

Dos três que foram recolhidos em níveis conservados da Idade do Ferro, um (MAR/043) foi 

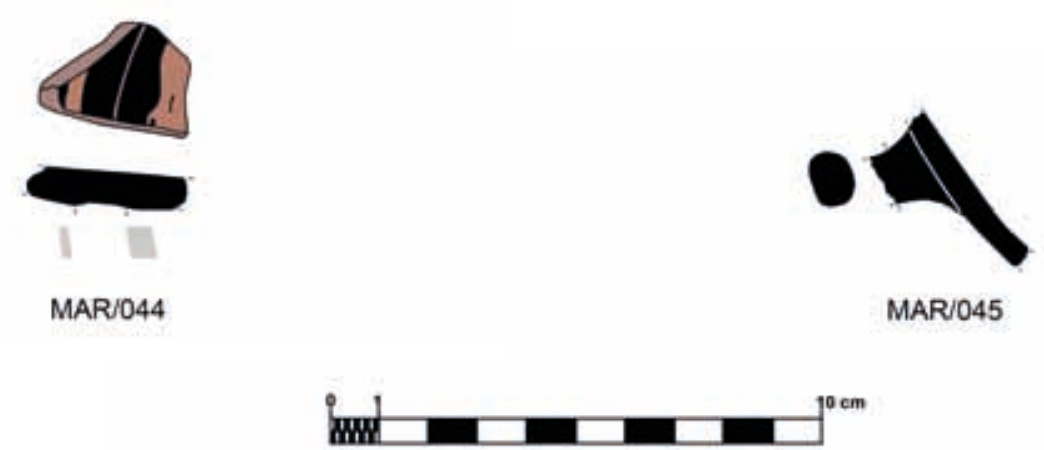

Fig. 18 - Cerâmica ática de figuras vermelhas do século IV a.n.e. de forma e pintor indeterminados.

recuperado durante o desmonte da estrutura [0405], estando associado a um fragmento de uma taça Cástulo (MAR/069). Um outro (MAR/044) foi recolhido no estrato de entulhamento [0545], já referido anteriormente. O terceiro (MAR/046) surgiu no nível 03 do Quadrado G 03, já comentado nas páginas anteriores, estando associado à taça do Pintor de Marlay (MAR/002).

\section{Catálogo}

MAR/043 - C. Mar. 2003 Sector 01 [0405] 15385. Pequeno fragmento de fundo e arranque de pé. Pasta de cor laranja claro, dura, compacta e depurada. Verniz negro, com brilho metalizado, aderente e espesso. O fundo interno apresenta-se decorado com dois círculos concêntricos. Não ilustrado.

MAR/044 - C. Mar. 2002 Sector 01 [0545] 6054. Fragmento de fundo, arranque de parede e zona de fratura correspondente ao arranque de pé. Pasta de cor laranja, dura, compacta e depurada. Verniz negro, aderente, espesso e brilhante. A superfície interna apresenta motivo indeterminado, delimitado por círculo concêntrico inciso e círculo concêntrico reservado. A superfície externa do fundo apresenta-se em reserva com círculo concêntrico em verniz negro. Encontra-se estratigraficamente associado a um fragmento de taça atribuído ao grupo do Pintor de Viena 116. Espessura máx.: 0,6 cm.

MAR/045 - C. Mar. 2002 Sector 01 [0109] 2140. Fragmento de parede e arranque de asa. Apresenta decoração composta de vestígios de motivos indeterminados. Pasta de cor bege, dura, compacta e depurada. Verniz negro, aderente, espesso e brilhante. Espessura Máx.:0,52 cm.

MAR/046 - C. Mar. 1984 Corte 01 Quadrado G 03 Nível 3 2835. Fragmento de parede. Decorado na superfície externa com motivo indeterminado. Pasta de cor laranja claro, dura, compacta e depurada. Verniz negro, pouco espesso na superfície interna, brilhante e aderente. Bibliografia: Arruda 1997: 121. Não ilustrado.

\subsubsection{A cerâmica ática de verniz negro}

A cerâmica de verniz negro é muito mais numerosa, tendo-se contabilizado 263 fragmentos (182 indivíduos), no total. Destes, apenas 145 indivíduos foram passíveis de integração tipológica, pertencendo 74 a formas datáveis do último quartel do século $V$ e as restantes da primeira metade do IV a.n.e. 


\subsubsection{As taças Cástulo}

As taças Cástulo (42A de Lamboglia; insept lip da Ágora de Atenas) são muito abundantes no Castelo de Castro Marim, tendo em consideração não só os bordos e paredes, mas também muitos dos pés e fundos recuperados. Naturalmente que não esquecemos que estes últimos, que pertencem, indubitavelmente a taças sem pé (stemless cup), podem, até mesmo pela associação contextual, corresponder a muitos dos primeiros.

Foram contabilizados 65 fragmentos - 55 indivíduos, correspondentes a peças integralmente reconstituíveis, a bordos e a paredes. Dez destes apareceram em contexto fechado, concretamente na UE [0089], com características únicas em Castro Marim e que, como já fizemos referência na introdução, foi considerada um depósito de características votivas (Arruda - Freitas 2008; Arruda et al. 2009). Neste mesmo contexto, as taças Cástulo estão associadas a kilikes da Classe Delicada e de tipo plain rim. Outros materiais como as ânforas, concretamente um numeroso conjunto de Pellicer B/C e de Mañá Pascual A4 (variante 11.2.1.3., 11.2.1.4 e 11.2.1.6. de Ramón Torres) completam o repertório material desta unidade estratigráfica.

As taças Cástulo do Castelo de Castro Marim correspondem à versão "standard" da forma, tal como foi definida na Ágora de Atenas, com bordo convexo, diferenciado do corpo através de ressalto bem marcado em ambas as superfícies. Os pés, anelares, exibem caneluras na face externa, face que está quase sempre reservada, bem como a sua superfície de apoio. Também o fundo externo não tem verniz, possuindo um círculo negro concêntrico e um ponto, no centro. Trata-se, portanto, e a avaliar por estas características específicas, de exemplares relativamente arcaicos, da segunda metade do século V a.n.e. (Sparkes - Talcott 1970: 101-102).

Este tipo de stemless cup é muito frequente na Península Ibérica quer no Levante e na Catalunha, quer na Andaluzia, especificamente no sítio epónimo, e ainda na Extremadura, onde o conjunto de Cancho Roano se destaca não só pela quantidade, mas também pelo enquadramento cronológico que o sítio lhes proporcionou (Gracia Alonso 2003). Em Portugal, são conhecidas em Mértola (Arruda - Barros - Lopes 1998), mas também em Tavira (Barros 2003, 2005) e em Lisboa (Arruda - Sousa, 2018), e ainda, no interior alentejano, nas Mesas do Castelinho, em Almodôvar (Estrela 2010), na Azougada, em Moura (Rouillard 1991), em Fernão Vaz, Ourique (Beirão - Correia 1991), no Alto do Castelinho da Serra, Montemor-o-Novo (Gibson et al. 1998) e na área de Neves Corvo (Maia - Maia 1986), constituindo, no Extremo Ocidente peninsular, o vaso grego do século $\checkmark$ a.n.e., por excelência, situação que aliás, repete a da restante Península Ibérica (Sánchez Fernandez 1992, Gracía Alonso 1994, Martín Ruiz et al. 1995, Shefton 1995). De facto, e ainda que, teoricamente, as taças Cástulo possam ter continuado a importar-se durante a primeira metade do século IV a.n.e., o certo é que a sua presença é sempre insignificante nestas cronologias, como se pode perceber, por exemplo, no depósito de Zacatín (Adroher Auroux - Sanchéz Moreno Torre Castellano 2016), onde este tipo de vaso corresponde a uns escassos 1,35\% do conjunto de cerâmica grega de verniz negro.

Vários dos fragmentos de taças Cástulo recolhidos no Castelo de Castro Marim foram recuperados em contextos conservados da Idade do Ferro, dos quais se deve destacar o das U.Es. [0089=0078]. Estas unidades estratigráficas, que correspondem a um bothros (Arruda - Freitas 2008; Arruda et al. 2009), ofereceram materiais muito bem conservados, que, no seu conjunto, são muito coerentes do ponto de vista cronológico. Entre a cerâmica ática, a forma mais bem representada é a taça Cástulo, que conta com 13 fragmentos (10 NMI) (MAR/047, MAR/049, MAR/051, MAR/055, MAR/058, MAR/060, MAR/070, MAR/072, MAR/077, MAR/089, MAR/093, $M A R / 100, M A R / 106)$. As restantes cerâmicas gregas incorporam taças de tipo Plain Rim (MAR/122, $M A R / 123$ e MAR/124) e Classe Delicada (MAR/117), fundos que podem corresponder a stemless cups - MAR/126, MAR/131, MAR/134, e ainda fragmentos de asas, paredes e fundos de forma indeterminada (MAR/260, MAR/264, MAR/289, MAR/291, MAR/293, MAR/299, MAR/305). Refirase ainda a presença muito significativa de outras categorias cerâmicas, entre as quais, se devem destacar as várias dezenas de recipientes anfóricos sobretudo das formas Pellicer B/C e Maña Pascual A4 - variantes 11.2.1.3, 11.2.1.4 e 11.2.1.6 de Ramón Torrres. 


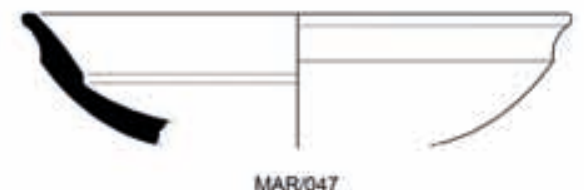

MARO47

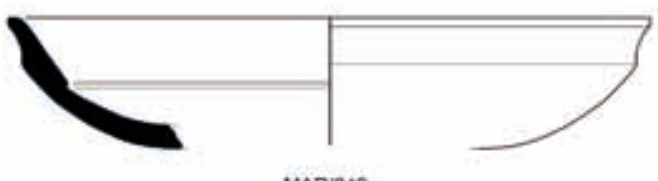

MARIOA9
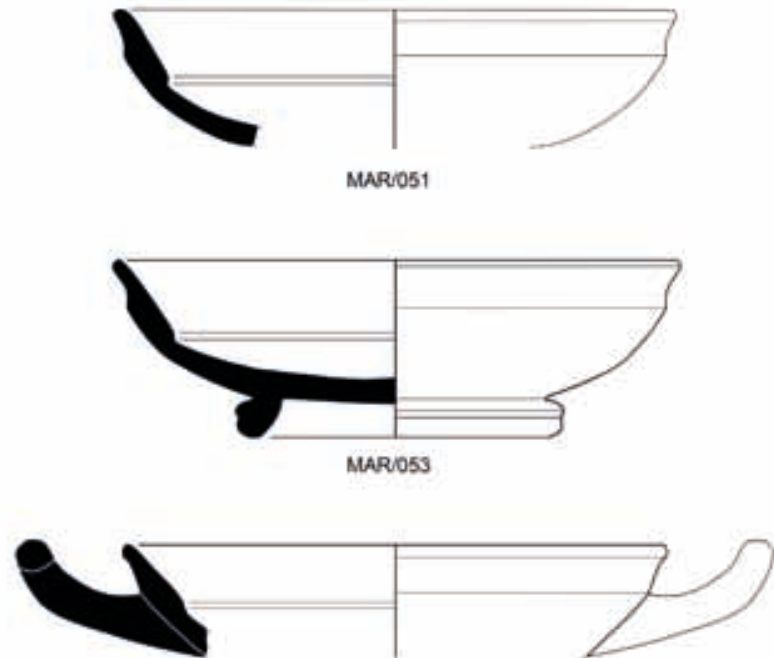

MARJO5S

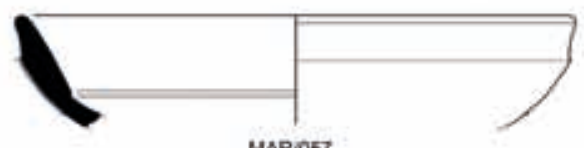

MAR/057

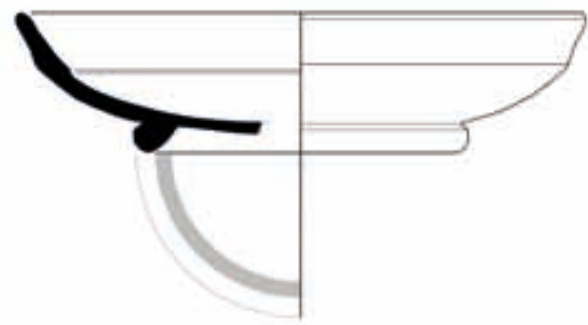

MAR059

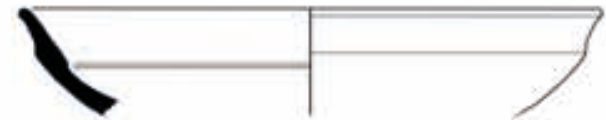

MARO48

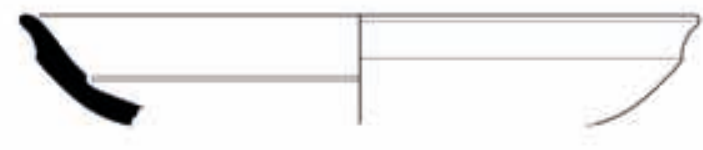

MARIOSO
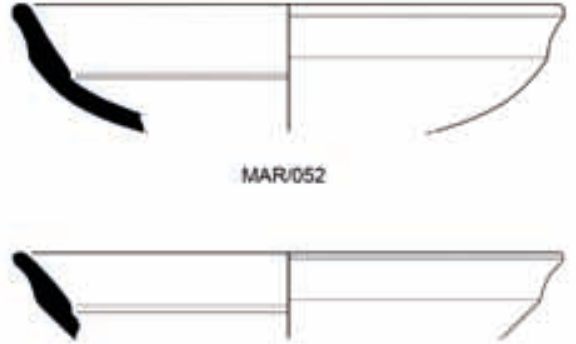

MARO5:

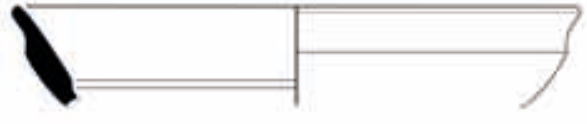

MAR/OS6

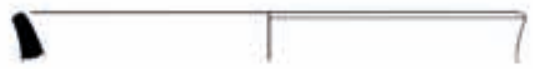

MARIOSB

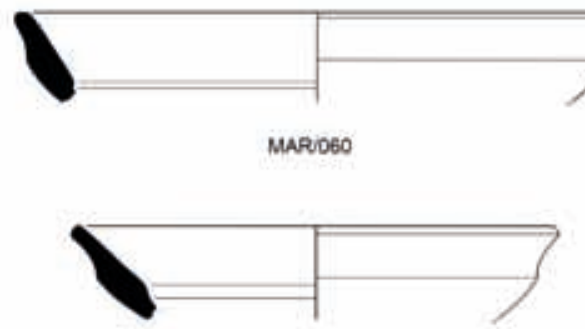

MAROE1

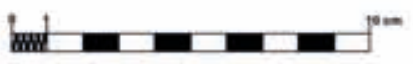

Fig. 19 - Taças Cástulo de cerâmica ática de verniz negro do século V/IV a.n.e. 


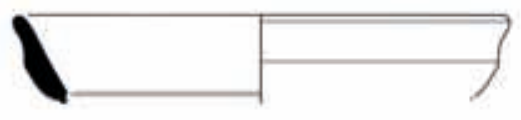

MAR/062

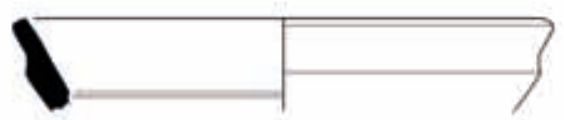

MAROSA

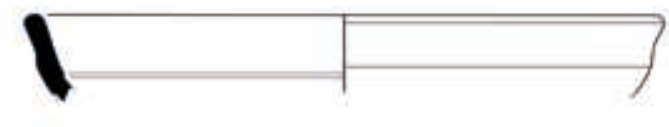

MARIO66

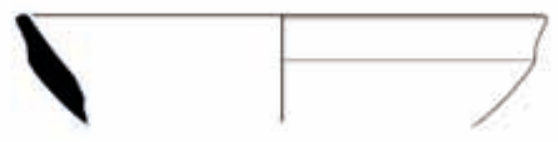

MAROES

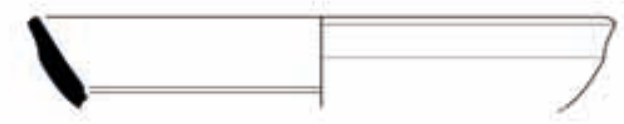

MARJ065

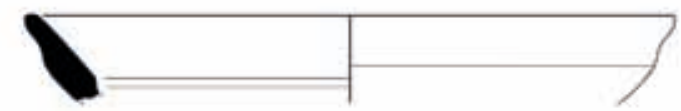

MARID67
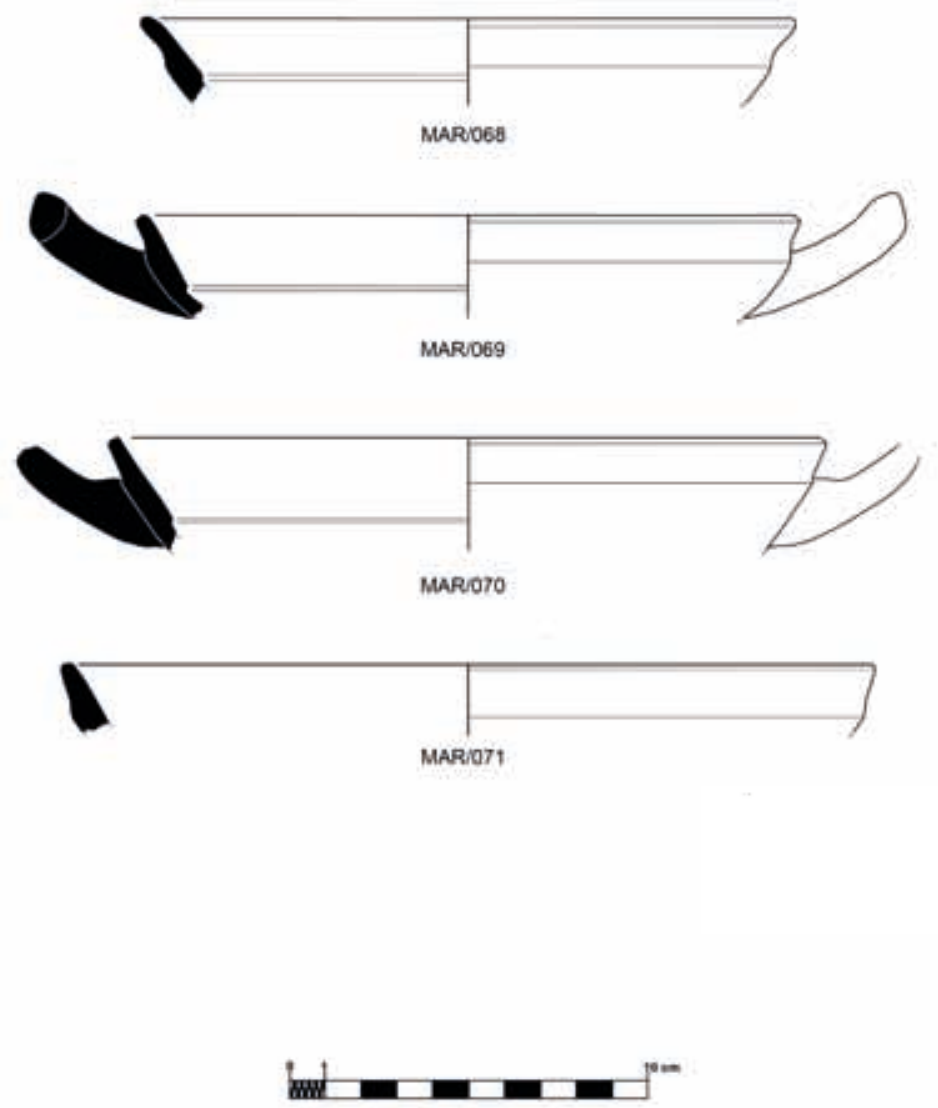

Fig. 20 - Taças Cástulo de cerâmica ática de verniz negro do século V/IV a.n.e. 

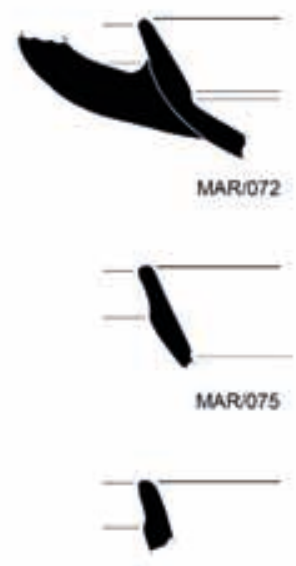

MARUTE

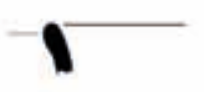

MAROS1

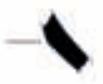

MARUDS

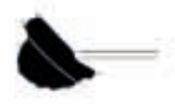

MARTOB?

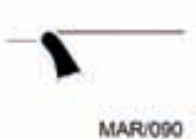

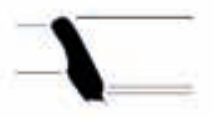

MARNOT3
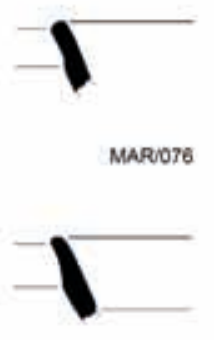

MARIOTY

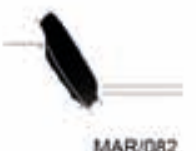

MARUOB2

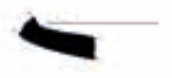

MARIOES

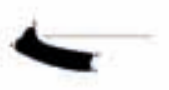

MARUES

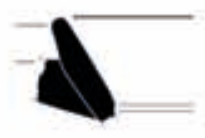

MARI074
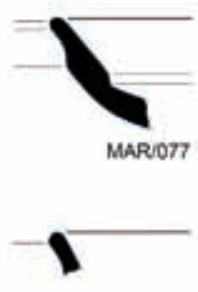

MARIOSO

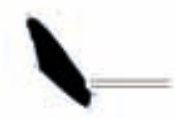

MARDS3

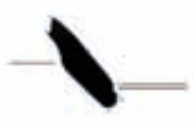

MARUDSE

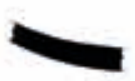

MARUOS9
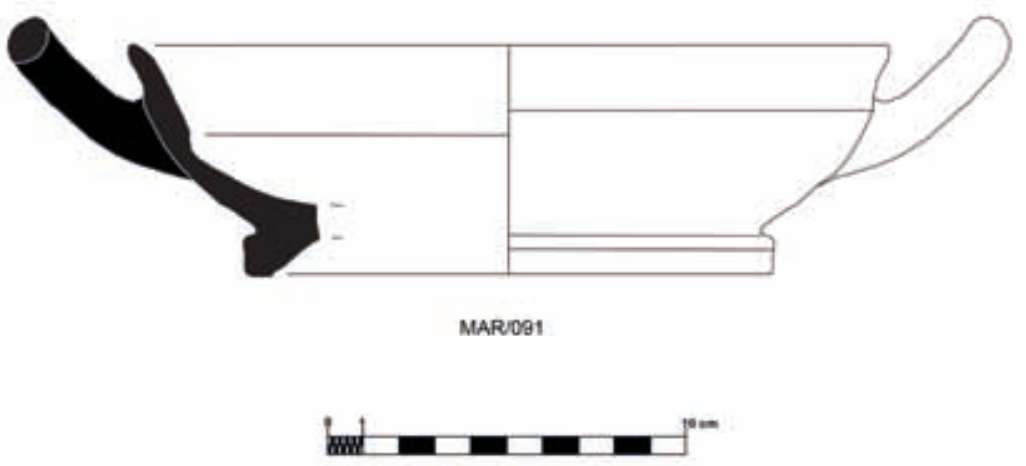

Fig. 21 - Taças Cástulo de cerâmica ática de verniz negro do século V/IV a.n.e. 

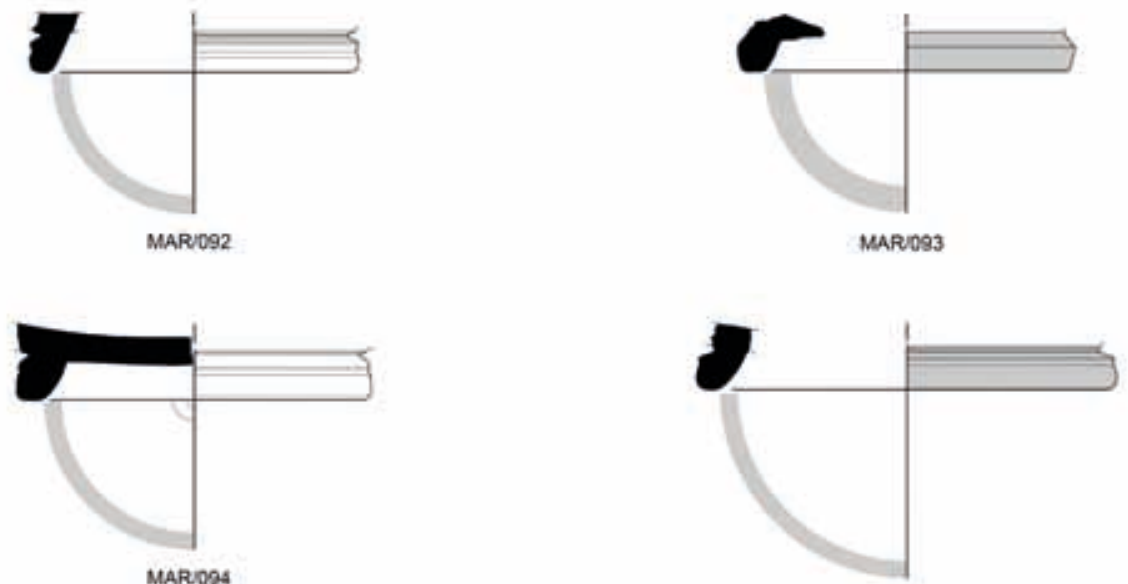

MARUQS5
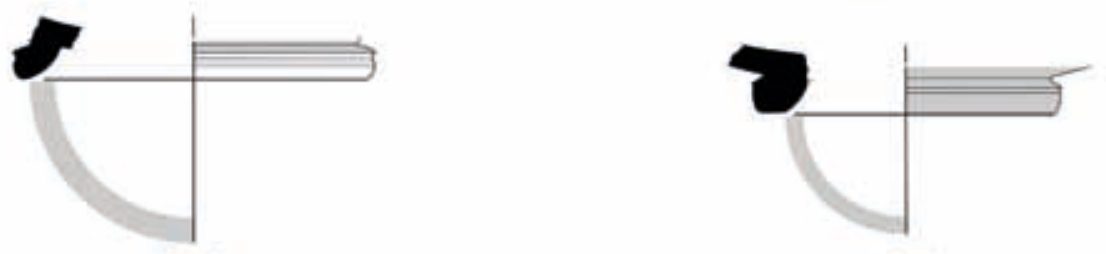

MAROP7
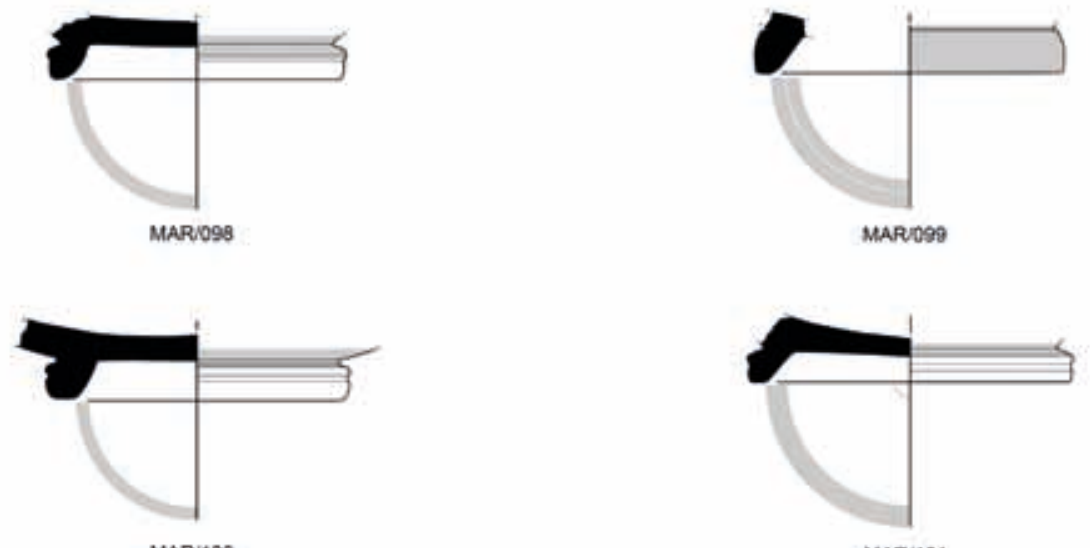

MAR/100

MAR/10
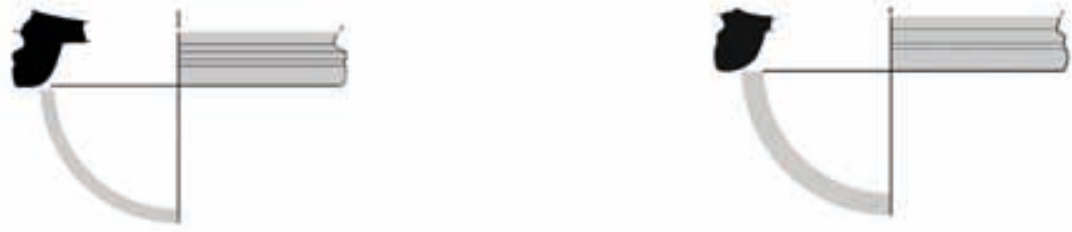

MARIT22

MAR/103

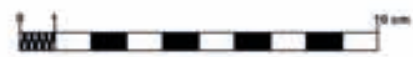

Fig. 22 - Taças Cástulo de cerâmica ática de verniz negro do século V/IV a.n.e. 


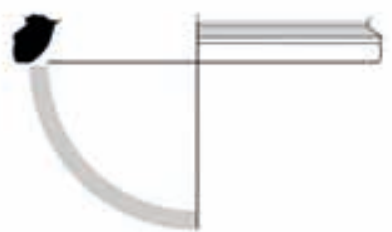

MAR/104
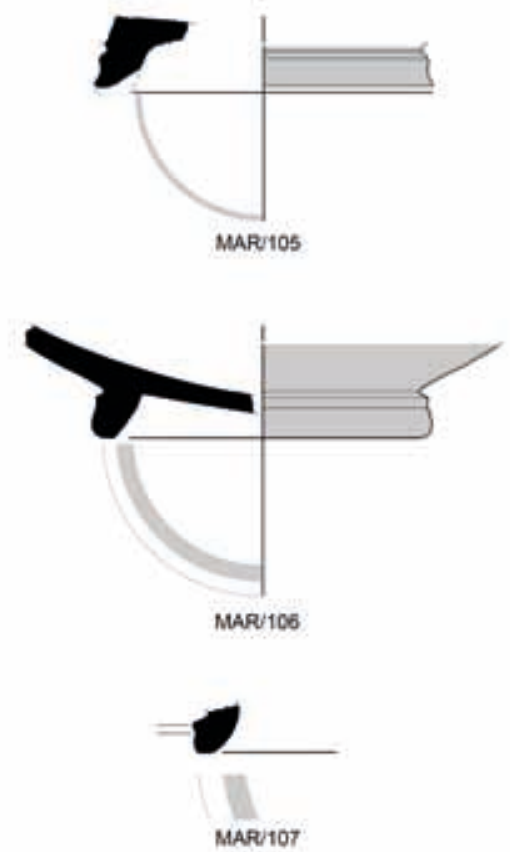

MAR/107

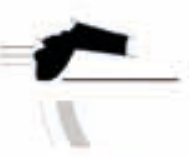

MAR/108
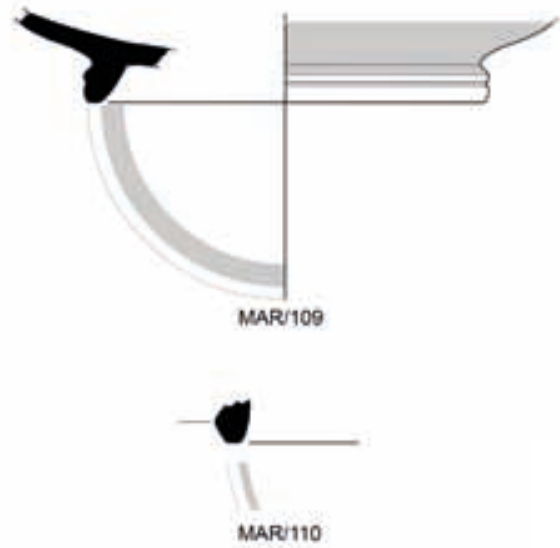

藏

Fig. 23 - Taças Cástulo de cerâmica ática de verniz negro do século V/IV a.n.e. 
Outros fragmentos de taças Cástulo foram recolhidos em níveis de idêntica cronologia. É o caso da U.E. [0766], que corresponde ao enchimento de uma fossa, que proporcionou três taças Cástulo bem conservadas (MAR/053, MAR/065, MAR/091), em associação a um fragmento de skyphos de verniz negro (MAR/149), um fundo de uma stemless cup (MAR/139) e também vários exemplares de ânforas tipo Pellicer B/C e Maña Pascual A4 (variante 11.2.1.3 de Ramon Torres). Outros exemplares de taças Cástulo foram recolhidos em níveis de derrube/entulhamento (U.E. [0680] - MAR/066; U.E. [0547] - MAR/099; U.E. [704] - MAR/109; U.E. [0570] - MAR/085; U.E. [0110] - MAR/088), pavimentos (U.E. [0076] - MAR/063; U.E. [0423] - MAR/071; U.E. [0112] MAR/082) e estruturas (U.E. [1045] - MAR/074; U.E. [87] - MAR/084; U.E. [0037] - MAR/090), datados da segunda metade/finais do século $V$ a.n.e., estando por vezes associadas a ânforas do tipo Pellicer $B / C$., e em enchimentos de fossas e estratos de aterro (Quadrado E 06, Nível 5 MAR/059; Quadrado E 05, Nível 5 - MAR/097, MAR/111 e MAR/102). Um caso particular diz respeito ao Quadrado E 10, Nível 5, onde um fragmento de taça Cástulo (MAR/o86) surge associado a um fragmento de skyphos (MAR/147), podendo este contexto ser datado ou de finais do século $\mathrm{V}$ a.n.e. ou já da primeira metade da centúria seguinte.

Esta mesma morfologia aparece, ainda que raramente, também em níveis que se podem datar da primeira metade do século IV a.n.e., sendo difícil estabelecer se correspondem a materiais residuais ou se estavam ainda em utilização. É o caso dos fragmentos MAR/o68 (U.E. [0535]) e MAR/069 (U.E. [0405]), que surgem associados a fragmentos de cerâmica ática de figuras vermelhas, um dos quais seguramente atribuível ao Pintor de Viena 116, como já foi referido anteriormente. Em um outro caso, a taça Cástulo (MAR/076 - U.E. [0482]) acompanhava uma ânfora tipo 12.1.1.1 de Ramon Torres, o que sugere também uma cronologia já enquadrável no século IV a.n.e. Por último, cabe destacar o contexto identificado no Quadrado C04 Nível 03, onde os dois fragmentos de taças Cástulo (MAR/095 e MAR/096) apareceram com uma taça da Classe Delicada (MAR/116), com formas Lamboglia 22 (MAR/161 e MAR/163), 23 (MAR/202), com fragmentos indeterminados (MAR/247 e MAR/272) e ainda com ânforas do tipo Pellicer $B / C$, sugerindo uma datação em torno à primeira metade do século IV a.n.e.

Outros fragmentos surgiram ainda em níveis conservados da Idade do Ferro, mas têm provavelmente um carácter residual. É o caso de vários fragmentos de taças Cástulo (MAR/048 U.E. [0592]; MAR/067 - Quadrado F03 Nível 4; MAR/105 - Quadrado E03 Nível 04) que estavam em níveis que continham outros vasos áticos do século IV a.n.e., mas que estão associados também a fragmentos de cerâmicas de tipo Kuass, ânforas dos tipos Pellicer B/C e D, Maña Pascual A4 (séries 11 e 12 de Ramon Torres) e Tiñosa (8.1.1.2), o que indica uma cronologia de formação destes estratos posterior ao terceiro quartel do século IV a.n.e.

\section{Catálogo}

MAR/047 - C. Mar. 2000 Sector 01 [0089] 0890. Três fragmentos com colagem entre si, correspondendo a bordo e parede. Apresenta lábio côncavo na superfície externa e ressalto bem marcado na superfície interna, a marcar a ligação do lábio à parede. Pasta de cor bege, dura, compacta e depurada. Verniz negro, aderente, espesso e pouco brilhante, com incrustações e manchas acinzentadas, estas últimas mais abundantes na superfície externa. Diâmetro de bordo: 15,4 cm. Bibliografia: Arruda 2007: 144, fig. 75.

MAR/048 - C. Mar. 2002 Sector 01 [0592] 6095. Fragmento de bordo e parede. Apresenta lábio côncavo na superfície externa e ressalto bem marcado na superfície interna, a marcar a ligação do lábio à parede. Pasta de cor laranja clara, dura, compacta e depurada. Verniz negro, aderente, espesso e brilhante, simultaneamente nas superfícies interior e exterior. Diâmetro de bordo: $16,3 \mathrm{~cm}$.

MAR/049 - C. Mar. 2000 Sector 01 [0089] 0901. Dois fragmentos com colagem entre si, correspondendo a bordo e parede. Apresenta lábio côncavo na superfície externa e ressalto 
bem marcado na superfície interna, a marcar a ligação do lábio à parede. Pasta de cor bege, dura, compacta e muito depurada. Verniz negro, aderente, espesso e pouco brilhante. Na superfície interior o verniz apresenta abundantes incrustações. Diâmetro de bordo: $18 \mathrm{~cm}$.

MAR/050 - C. Mar. 1984 Corte 01 Quadrado E 04 Nível 04 2786. Fragmento de bordo e parede. Apresenta lábio côncavo na superfície externa e ressalto bem marcado na superfície interna, a marcar a ligação do lábio à parede. Pasta de cor bege e tonalidade alaranjada, dura, compacta e depurada. Verniz negro, aderente, espesso e baço. Diâmetro de bordo: 19,1 cm. Bibliografia: Arruda 1997: 125.

MAR/051 - C. Mar. 2000 Sector 01 [0089] 0891. Fragmento de bordo e parede. Apresenta lábio côncavo na superfície externa e ressalto bem marcado na superfície interna, a marcar a ligação do lábio à parede. Pasta de cor bege, dura, compacta e muito depurada. Verniz negro, com manchas avermelhadas na face interior e acinzentadas na superfície exterior. O verniz, aderente e espesso, apresenta-se particularmente bem conservado na superfície interior. Diâmetro de bordo: $15,7 \mathrm{~cm}$.

MAR/052 - C. Mar. 2000 Sector 01 [sup.] 10152. Fragmento de bordo e parede. Apresenta lábio côncavo na superfície externa e ressalto bem marcado na superfície interna, a marcar a ligação do lábio à parede. Pasta de cor bege e tonalidade amarelada, dura, compacta e depurada. Verniz negro com manchas avermelhadas, aderente, pouco espesso e baço. Diâmetro de bordo: $15,3 \mathrm{~cm}$.

MAR/053 - C. Mar. 2003 Sector 01 [0766] 10073. Fragmento de bordo, parede, fundo e pé. Apresenta lábio côncavo na superfície externa e ressalto bem marcado na superfície interna, a marcar a ligação do lábio à parede. Pé anelar e moldurado. Pasta de cor bege e tonalidade alaranjada, dura, compacta e depurada. Verniz negro, aderente, espesso e brilhante. Diâmetro de bordo: $15,95 \mathrm{~cm}$; diâmetro de pé: $8,7 \mathrm{~cm}$.

MAR/054 - C. Mar. 1987 Corte 03 Quadrado D 05 Nível 01 2850. Fragmento de bordo e parede. Apresenta lábio côncavo na superfície externa e ressalto bem marcado na superfície interna, a marcar a ligação do lábio à parede. Pasta de cor laranja clara, dura, compacta e depurada. Verniz negro com manchas acinzentadas, aderente e espesso. Diâmetro de bordo: 15,30 cm.

MAR/055 - C. Mar. 2002 Sector 01 [0089] 7435. Fragmento de bordo, parede e asa. Apresenta lábio côncavo na superfície externa e ressalto bem marcado na superfície interna, a marcar a ligação do lábio à parede. Pasta de cor bege, dura, compacta e muito depurada. Verniz negro, aderente, espesso, brilhante e acetinado. $O$ verniz está presente em todas as superfícies, apresentando-se particularmente deteriorado na parte interna da asa. Diâmetro de bordo: 15,1 cm. Bibliografia: Arruda 2007: 144.

MAR/056 - C. Mar. Sup. sem n. 06. Fragmento de bordo e parede. Apresenta lábio côncavo na superfície externa e ressalto bem marcado na superfície interna, a marcar a ligação do lábio à parede. Pasta de cor bege e tonalidade acinzentada, dura, compacta e depurada. Verniz negro, aderente, espesso e brilhante. Diâmetro de bordo: $15,7 \mathrm{~cm}$.

MAR/057 - C. Mar. 1987 Corte 03 Quadrado D 04 Nível 01 2787. Fragmento de bordo e parede. Apresenta lábio côncavo na superfície externa e ressalto bem marcado na superfície interna, a marcar a ligação do lábio à parede. Na superfície externa é visível, imediatamente a seguir ao lábio, uma área de fractura que corresponde ao arranque de uma asa. Pasta de cor cinzenta e tonalidade esverdeada, dura, compacta e depurada. Verniz negro de tonalidade esverdeada, pouco aderente, espesso e baço. Diâmetro de bordo: 15,3 cm. Bibliografia: Arruda 1997: 125-126.

MAR/058 - C. Mar. 2002 Sector 01 [0089] 0886. Fragmento de bordo e parede. Apresenta 
lábio côncavo na superfície externa. Pasta de cor bege, dura, compacta e depurada. Verniz negro, aderente, espesso e brilhante. Diâmetro de bordo: $13,95 \mathrm{~cm}$.

MAR/059 - C. Mar. 1987 Corte 03 Quadrado E 06 Nível 05 2785. Dois fragmentos com colagem entre si, correspondendo a bordo, parede e fundo. Apresenta lábio côncavo na superfície externa e ressalto bem marcado na superfície interna, a marcar a ligação do lábio à parede. Exibe pé anelar e moldurado. Apresenta em reserva a superfície externa do fundo e a superfície de apoio do pé. Pasta de cor castanha clara, dura, compacta, depurada, sendo visíveis pequenas partículas de mica. Verniz negro, aderente, espesso, brilhante e acetinado. Diâmetro de bordo: $15,9 \mathrm{~cm}$, diâmetro de pé: 8,7 cm. Bibliografia: Arruda 1997: 125, fig. 1:5.

MAR/060 - C. Mar. 2000 Sector 01 [0089] 0877. Fragmento de bordo e parede. Apresenta lábio côncavo na superfície externa e ressalto bem marcado na superfície interna, a marcar a ligação do lábio à parede. Pasta de cor laranja clara, dura, compacta e muito depurada. Verniz negro, com manchas avermelhadas, espesso, aderente, pouco brilhante e acetinado. Diâmetro de bordo: $16,8 \mathrm{~cm}$.

MAR/061 - C. Mar. 2000 Sector 01 [sup.] 0010. Fragmento de bordo e parede. Apresenta lábio côncavo na superfície externa e ressalto bem marcado na superfície interna, a marcar a ligação do lábio à parede. Pasta de cor laranja, dura, compacta e depurada. Verniz negro, com manchas avermelhadas, pouco aderente e espesso. Diâmetro de bordo: $13,3 \mathrm{~cm}$.

MAR/062 - C. Mar. Sup. sem n. 07. Fragmento de bordo e parede. Apresenta lábio côncavo na superfície externa e ressalto bem marcado na superfície interna, a marcar a ligação do lábio à parede. Pasta de cor bege e tonalidade acinzentada, dura, compacta e depurada. Verniz negro, aderente, espesso e muito brilhante. Diâmetro de bordo: $13,4 \mathrm{~cm}$.

MAR/063 - C. Mar. 2000 Sector 01 [0076] 0947. Fragmento de bordo e parede. Apresenta lábio côncavo na superfície externa. Pasta de cor laranja clara, dura, compacta e depurada. Verniz negro, aderente, espesso e brilhante. Diâmetro de bordo: $14,4 \mathrm{~cm}$.

MAR/064 - C. Mar. 2000 Sector 01 [sup.] 1068. Fragmento de bordo e parede. Apresenta lábio côncavo na superfície externa e ressalto bem marcado na superfície interna, a marcar a ligação do lábio à parede. Pasta de cor laranja clara, dura, compacta e muito depurada. Verniz negro com manchas acastanhadas, aderente, pouco brilhante e acetinado. O verniz apresenta-se pouco espesso na superfície interna. Diâmetro de bordo: 14,4 cm.

MAR/065 - C. Mar. 2000 Sector 01 [0766] 11660. Fragmento de bordo e parede. Apresenta lábio côncavo na superfície externa e ressalto bem marcado na superfície interna, a marcar a ligação do lábio à parede. Pasta de cor bege, dura, compacta e depurada. Verniz negro, aderente, espesso e brilhante. Diâmetro de bordo: $15,8 \mathrm{~cm}$.

MAR/066 - C. Mar. 2003 Sector 01 [0680] 12199. Três fragmentos com colagem entre si, correspondendo a bordo e parede. Apresenta lábio côncavo na superfície externa e ressalto bem marcado na superfície interna, a marcar a ligação do lábio à parede. Pasta de cor bege e tonalidade acinzentada, dura, compacta e depurada. Verniz muito deteriorado e totalmente desaparecido na superfície interna. Verniz de cor negra, aderente, espesso e brilhante. Diâmetro de bordo: 17,4 cm.

MAR/067 - C. Mar. 1986 Corte 01 Quadrado F 03 Nível 04 4071. Fragmento de bordo e parede. Apresenta lábio côncavo na superfície externa e ressalto bem marcado na superfície interna, a marcar a ligação do lábio à parede. Pasta de cor laranja, dura, compacta e depurada. Verniz muito deteriorado, negro com manchas acastanhadas, pouco aderente, pouco espesso e brilhante. Diâmetro de bordo: $18 \mathrm{~cm}$. 
MAR/068 - C. Mar. 2003 Sector 01 [0535] 10047. Fragmento de bordo e parede. Apresenta lábio côncavo na superfície externa e ressalto bem marcado na superfície interna, a marcar a ligação do lábio à parede. Pasta de cor laranja clara, dura, compacta e depurada. Verniz negro com manchas esverdeadas, aderente, espesso e pouco brilhante. Diâmetro de bordo: $18 \mathrm{~cm}$.

MAR/069 - C. Mar. 2003 Sector 01 [0405] 10085. Dois fragmentos com colagem entre si, correspondendo a bordo, parede e asa. Apresenta lábio côncavo na superfície externa e ressalto bem marcado na superfície interna, a marcar a ligação do lábio à parede. O interior da asa e a área entre asas encontram-se em reserva. Pasta de cor bege e tonalidade alaranjada, dura, compacta e depurada. Verniz negro, aderente, espesso, de brilho metalizado. Diâmetro de bordo: 18,16 cm.

MAR/070 - C. Mar. 2000 Sector 01 [0089] 0883. Fragmento de bordo, parede e asa. Apresenta lábio côncavo na superfície externa e ressalto bem marcado na superfície interna, a marcar a ligação do lábio à parede. A asa encontra-se fraturada na extremidade. Pasta de cor bege, dura, compacta e depurada. Verniz negro com abundantes manchas avermelhadas. $O$ verniz apresentase muito deteriorado na superfície exterior, impossibilitando a identificação de áreas em reserva. Diâmetro de bordo: $19,5 \mathrm{~cm}$.

MAR/071 - C. Mar. 2003 Sector 01 [0423] 6063. Fragmento de bordo e parede. Apresenta lábio côncavo na superfície externa. Pasta de cor laranja clara, dura, compacta e depurada. Verniz negro, com manchas acinzentadas, aderente, pouco espesso e brilhante. Diâmetro de bordo: 22,4 cm.

MAR/072 - C. Mar. 2000 Sector 01 [0089] 0879. Fragmento de bordo, parede e asa. Apresenta lábio côncavo na superfície externa e ressalto bem marcado na superfície interna, a marcar a ligação do lábio à parede. A asa encontra-se fraturada na extremidade. O interior da asa e a área entre asas encontram-se em reserva. Pasta de cor bege, dura, compacta e depurada. Na superfície interna o verniz apresenta-se negro, aderente e espesso. Na superfície externa o verniz exibe abundantes manchas vermelhas, apresentando-se pouco aderente.

MAR/073 - C. Mar. 2000 Sector 01 [sup.] 1065. Fragmento de bordo e parede. O bordo encontrase muito fraturado. Lábio côncavo na face externa e ressalto bem marcado na face interna, a marcar a ligação do lábio à parede. Pasta de cor bege, dura, compacta e depurada. Verniz negro com manchas avermelhadas, aderente, pouco espesso e brilhante.

MAR/074 - C. Mar. 2000 Sector 01 [1045] 10930. Fragmento de bordo, parede e asa. Apresenta lábio côncavo na superfície externa e ressalto bem marcado na superfície interna, a marcar a ligação do lábio à parede. A asa encontra-se fraturada. A área entre asas apresenta-se reservada. Pasta de cor bege e tonalidade acinzentada, dura, compacta e depurada. Verniz negro, aderente, espesso na superfície interior e pouco espesso na exterior.

MAR/075 - C. Mar. 2000 Sector 01 [0557] 6041. Dois fragmentos com colagem entre si, correspondendo a bordo e parede. O bordo encontra-se muito fraturado. Apresenta lábio côncavo na superfície externa e ressalto bem marcado na superfície interna, a marcar a ligação do lábio à parede. Pasta de cor bege e tonalidade alaranjada, dura, compacta e depurada. Verniz negro, aderente, espesso e brilhante.

MAR/076 - C. Mar. 2002 Sector 01 [0482] 6081. Fragmento de bordo e parede. Apresenta lábio côncavo na superfície externa e ressalto bem marcado na superfície interna, a marcar a ligação do lábio à parede. Pasta de cor bege, dura, compacta e depurada. Verniz negro, aderente, espesso e brilhante. 
MAR/077 - C. Mar. 2002 Sector 01 [0089] 6094. Fragmento de bordo e parede. Apresenta lábio côncavo na superfície externa e ressalto bem marcado na superfície interna, a marcar a ligação do lábio à parede. Pasta de cor bege e tonalidade acinzentada, dura, compacta e depurada. Verniz de boa qualidade, negro, aderente, espesso e brilhante.

MAR/078 - C. Mar. 2001 Sector 01 [0109] 1935. Fragmento de bordo e parede. Apresenta lábio côncavo na superfície externa. Pasta de cor laranja clara, dura, compacta e depurada. Verniz negro, aderente, espesso e brilhante.

MAR/079 - C. Mar. 2002 Sector 01 [0385] 5896. Fragmento de bordo e parede. Apresenta lábio côncavo na superfície externa e ressalto bem marcado na superfície interna, a marcar a ligação do lábio à parede. Pasta de cor bege, dura, compacta e depurada. Verniz negro, muito deteriorado.

MAR/080 - C. Mar. 2002 Sector 01 [sup.] 6254. Fragmento de bordo. Apresenta lábio côncavo na superfície externa. Pasta de cor laranja clara, dura, compacta e depurada. Verniz negro, aderente, espesso e brilhante.

MAR/081 - C. Mar. 2002 Sector 01 [0385] 5914. Fragmento de bordo. Apresenta lábio côncavo na superfície externa. Pasta de cor laranja, dura, compacta e depurada. Verniz negro, aderente, espesso e baço.

MAR/082 - C. Mar. 2001 Sector 01 [0112] 3513. Fragmento de parede e arranque de asa. O lábio, ainda que fraturado na extremidade, apresentar-se-ia côncavo na face externa e com um ressalto bem marcado na face interna, a marcar a ligação do lábio à parede. A área entre asas encontra-se em reserva. Pasta de cor bege e tonalidade alaranjada, dura, compacta e muito depurada. Verniz negro com manchas acastanhadas, aderente, espesso e brilhante.

MAR/083 - C. Mar. Sup. sem n. ${ }^{\circ}$ 08. Fragmento de parede. Apresenta ressalto bem marcado na superfície interna, a marcar a ligação do lábio à parede. Pasta de cor bege e tonalidade acinzentada, dura, compacta e depurada. Verniz negro, aderente, espesso e brilhante.

MAR/084 - C. Mar. 2000 Sector 01 [0087] 1699. Fragmento de parede. Apresenta o arranque do lábio, côncavo na superfície externa. Pasta de cor laranja, dura, compacta e depurada. Verniz negro, aderente, espesso e brilhante.

MAR/085 - C. Mar. 2000 Sector 01 [0570] 6099. Fragmento de parede com ressalto bem marcado na superfície interna. Pasta de cor bege, dura, compacta e depurada. Verniz negro, aderente, espesso e brilhante.

MAR/086 - C. Mar. 1988 Corte 04 Quadrado E 10 Nível 05 2852. Fragmento de bordo e parede. Apresenta lábio côncavo na superfície externa e ressalto bem marcado na superfície interna, a marcar a ligação do lábio à parede. Pasta de cor cinzenta e tonalidade esverdeada, dura, compacta e muito depurada. Verniz negro, aderente, espesso e baço. Bibliografia: Arruda 1997: 126.

MAR/087 - C. Mar. 1988 Corte 04 Quadrado E 10 Nível 03 2830. Fragmento de parede e arranque de asa. Apresenta ressalto bem marcado na face interna, a marcar a ligação do lábio, actualmente inexistente, à parede. Pasta de cor laranja e tonalidade acastanhada, dura, compacta e depurada. Verniz negro, aderente, espesso e brilhante. Bibliografia: Arruda 1997: 126.

MAR/088 - C. Mar. 2001 Sector 01 [0110] 3696. Fragmento de parede com ressalto bem marcado na superfície interna. Pasta de cor bege, dura, compacta e depurada. Verniz negro, aderente, espesso e brilhante. 
MAR/089 - C. Mar. 2000 Sector 01 [0089] 0891. Fragmento de parede. Pasta de cor laranja, dura, compacta e depurada. Verniz negro com manchas avermelhadas na superfície exterior. $\mathrm{O}$ verniz apresenta-se aderente, espesso e baço.

MAR/090 - C. Mar. 2000 Sector 01 [0037] 0904. Fragmento de bordo e parede. Apresenta lábio côncavo na superfície externa. Pasta de cor laranja clara, dura, compacta e depurada. Verniz negro, aderente, espesso e brilhante.

MAR/091 - C. Mar. 2003 Sector 01 [0766] 10072. Fragmento com perfil completo. Apresenta lábio côncavo na superfície externa e ressalto bem marcado na superfície interna, a marcar a ligação do lábio à parede. Pé anelar e moldurado. Pasta de cor laranja, dura, compacta e depurada. Verniz negro, aderente, espesso e brilhante. Diâmetro de bordo: $21,20 \mathrm{~cm}$; diâmetro de pé: 14,70 $\mathrm{cm}$.

MAR/092 - C. Mar. 2002 Sector 01 [0360] 3975. Fragmento de pé e arranque de parede. Pé anelar e moldurado. Apresenta a superfície de apoio e a face externa do pé em reserva. Pasta de cor laranja, dura, compacta e depurada. Verniz negro, com manchas acinzentadas, aderente, espesso e brilhante. Diâmetro de pé: $8,9 \mathrm{~cm}$.

MAR/093 - C. Mar. 2000 Sector 01 [0078] 0899. Fragmento de pé e arranque de fundo. Pé anelar. Apresenta a superfície de apoio do pé em reserva. Pasta de cor laranja, dura, compacta e depurada. São visíveis na pasta minúsculas partículas de mica. Verniz negro, aderente, espesso e brilhante. Diâmetro de pé: 9,1 cm.

MAR/094 - C. Mar. 1987 Corte 03 Quadrado B 06 Nível 02 2788. Fragmento de fundo e pé. Pé anelar e moldurado, com canelura na superfície externa. Apresenta a superfície de apoio e a face externa do pé em reserva. Fundo externo em reserva, decorado com círculo e ponto central em verniz negro. Pasta de cor laranja e tonalidade acastanhada, dura, compacta e depurada. Verniz negro, aderente, espesso e brilhante. Diâmetro de pé: 9,5 cm. Bibliografia: Arruda 1997: 126, fig. 1: 8 .

MAR/095 - C. Mar. 1987 Corte 03 Quadrado C 04 Nível 03 2793a. Fragmento de pé, arranque de fundo e arranque de parede. Pé anelar e moldurado. Apresenta a superfície de apoio do pé em reserva. Pasta de cor bege e tonalidade acinzentada, dura, compacta e depurada. Verniz negro, aderente, espesso e brilhante. Diâmetro de pé: 11,3 cm. Bibliografia: Arruda 1997: 126, fig. 1: 9.

MAR/096 - C. Mar. 1987 Corte 03 Quadrado C 04 Nível 03 2793b. Fragmento de pé. Pé anelar e moldurado. Apresenta superfície de apoio e face externa do pé em reserva. Pasta de cor laranja, dura, compacta e depurada. Verniz negro, aderente, espesso e brilhante. Diâmetro de pé: 9,7 cm.

MAR/097 - C. Mar. 1988 Corte 03 Quadrado E 05 Nível 05 2791. Fragmento de pé. Pé anelar e moldurado. Apresenta a superfície de apoio do pé em reserva. Pasta de cor laranja clara, dura, compacta e depurada. Verniz negro com manchas acastanhadas, aderente, espesso e baço. Diâmetro de pé: $8,28 \mathrm{~cm}$.

MAR/098 - C. Mar. Sup. sem n. ${ }^{\circ}$ 09. Fragmento de pé e fundo. Pé anelar e moldurado. Apresenta o fundo externo, a superfície de apoio e a face externa do pé em reserva. Pasta de cor laranja, dura, compacta e depurada. Verniz negro, aderente, espesso e brilhante. Diâmetro de pé: $8,1 \mathrm{~cm}$.

MAR/099 - C. Mar. 2002 Sector 01 [0547] 6045. Fragmento de pé, arranque de fundo e arranque de parede. Pé anelar. A ligação do pé à parede é feita, na superfície externa, através de uma fina canelura. Apresenta a superfície de apoio do pé em reserva. A face interna do pé encontra-se 
coberta de verniz, com excepção de uma fina linha que é deixada em reserva. Pasta de cor laranja, dura, compacta e pouco depurada. Verniz negro, aderente, espesso e muito brilhante. Diâmetro de pé: $8,6 \mathrm{~cm}$.

MAR/100 - C. Mar. 2002 Sector 01 [0089] 6074. Fragmento de pé, fundo e parede. Pé anelar e moldurado. Apresenta a superfície de apoio e a face externa do pé em reserva. Pasta de cor bege, dura, compacta e depurada. Verniz negro com abundantes manchas acinzentadas, aderente, espesso e brilhante. Diâmetro de pé: $8,12 \mathrm{~cm}$.

MAR/101 - C. Mar. Sup. sem n. ${ }^{\circ}$ 10. Fragmento de pé e fundo. Pé anelar e moldurado. Apresenta a superfície de apoio e a face externa do pé em reserva. $O$ fundo externo encontra-se igualmente em reserva, complementado com um círculo em verniz negro. Pasta de cor bege e tonalidade rosa, dura, compacta e depurada. Verniz negro, aderente, espesso e brilhante. Diâmetro de pé: 9 $\mathrm{cm}$.

MAR/102 - C. Mar. 1988 Corte 03 Quadrado E 05 Nível 03 2790; C. Mar. 1987 Corte 03 Quadrado D 05 Nível 04 2831. Dois fragmentos com colagem entre si correspondendo a pé e arranque de fundo. Pé anelar e moldurado. Apresenta a superfície de apoio do pé em reserva. Pasta de cor bege, dura, compacta e depurada. Verniz negro com manchas avermelhadas, aderente, pouco espesso e brilhante. Diâmetro de pé: $9,2 \mathrm{~cm}$.

MAR/103 - C. Mar. Sup. sem n. ${ }^{\circ} 11$. Fragmento de pé. Pé anelar e moldurado. Apresenta a superfície de apoio do pé em reserva. Pasta de cor laranja, dura, compacta e pouco depurada. Verniz negro, aderente, espesso e pouco brilhante. Diâmetro de pé: $9,7 \mathrm{~cm}$.

MAR/104 - C. Mar. 2002 Sector 01 [0360] 6029. Fragmento de pé. Pé anelar e moldurado. Apresenta a superfície de apoio e a face externa do pé em reserva. Pasta de cor cinzenta, dura, compacta e depurada. Verniz negro, aderente, espesso e brilhante. Diâmetro de pé: $10 \mathrm{~cm}$.

MAR/105 - C. Mar. 1983 Corte 01 Quadrado E 03 Nível 04 2826. Fragmento de fundo e pé. Pé anelar e moldurado. O pé encontra-se fracturado, não apresentando a superfície de apoio. Pasta de cor bege e tonalidade alaranjada, dura, compacta e depurada. Verniz negro, aderente, espesso e brilhante. Diâmetro de pé: 9,4 cm.

MAR/106 - C. Mar. 2000 Sector 01 [0089] 0876. Fragmento de fundo, pé e parede. Pé anelar e moldurado. Apresenta a superfície de apoio do pé e o fundo externo em reserva. Pasta de cor laranja clara, dura, compacta e depurada. Verniz negro, aderente, espesso e brilhante. Diâmetro de pé: $9,8 \mathrm{~cm}$.

MAR/107 - C. Mar. 1987 Corte 01 Quadrado D 05 Nível 01 1507. Fragmento de pé. Pé anelar e moldurado. A superfície de apoio apresenta-se em reserva. Pasta de cor laranja, dura, compacta e pouco depurada. Verniz negro, aderente, espesso e muito brilhante, com brilho ligeiramente metalizado.

MAR/108 - C. Mar. Sup. sem n. ${ }^{\circ} 12$. Fragmento de fundo e pé. Pé anelar e moldurado. Encontrase totalmente envernizado. Pasta de cor laranja clara, dura, compacta e depurada. Verniz negro, aderente, espesso e brilhante.

MAR/109-C. Mar. 2003 Sector 01 [0704] 11668. Dois fragmentos com colagem, correspondendo a parede, fundo e pé. Pé anelar e moldurado. Apresenta a superfície de apoio e a face externa do pé em reserva. Pasta de cor bege e tonalidade rosa, dura, compacta e depurada. Verniz negro com manchas acinzentadas, aderente, espesso e muito brilhante. Diâmetro de pé: $11 \mathrm{~cm}$. 
MAR/110 - C. Mar. Sup. sem n. ${ }^{\circ}$ 13. Fragmento de pé. Pé anelar. Pasta de cor bege, dura, compacta e depurada. Verniz negro, aderente, espesso e brilhante.

MAR/111 - C. Mar. 1988 Corte 03 Quadrado E 05 Nível 05 2792. Fragmento de pé, muito deteriorado e fracturado. Pasta de cor bege e tonalidade alaranjada, dura, compacta e depurada. Verniz negro, muito deteriorado. Não ilustrado.

\subsubsection{As taças da Classe Delicada}

As taças da Classe Delicada estão no sítio da foz do Guadiana representadas por oito peças, correspondentes a sete indivíduos, uma das quais (MAR/119) tinha sido já publicada, incluída no grupo dos kantharoi (Arruda 1997: 129 Fig. 2, n7). A classificação agora proposta é, contudo, avançada com muitas reservas, uma vez que a porção de pé é excessivamente reduzida, para haver certezas absolutas sobre a devida adscrição morfológica.

Os fundos externos estão decorados com círculos concêntricos pintados de verniz negro, que alternam com outros em reserva. Os pés, relativamente altos, são moldurados na superfície externa, estando reservada a sua superfície de apoio. A ligação do corpo ao fundo está marcada por uma linha sem qualquer verniz. São estes pormenores, e muito especialmente as áreas reservadas, mas também as molduras na superfície externa do pé, que indicam para estas taças de Castro Marim uma cronologia do século $V$ a.n.e., mais especificamente do último quartel, tendo em consideração a evolução formal observada na Ágora de Atenas (Sparkes - Talcott 1970). Por outro lado, a decoração de MAR/113 e MAR/116, sendo pouco frequente na Península Ibérica, regista-se, por exemplo, em dois fragmentos recolhidos em Tossal de Sant Miquel - Lliria, em València, que foram datados de 450-425 a.n.e. (Bonet 1995: 220, 229), e no Cerro del Prado, em Cádis, com uma cronologia balizada entre 425-375 a.n.e. (Rouillard 1991: 718).

Os dados contextuais lidos no sítio algarvio são também de reter, uma vez que nos quatro casos em que apareceram em níveis primários, estavam associados a outros materiais que acrescentam dados importantes em relação à sua cronologia. Um deles (MAR/117) foi recolhido na U.E. [0089=0078], já caracterizada anteriormente e datada dos finais do século $V$ a.n.e., estando associado a taças Cástulo e a uma taça de tipo Plain Rim. Um outro (MAR/113) foi exumado no pavimento [0679], também já mencionado, estando associado a um skyphoi de cerâmica ática de figuras vermelhas, decorado com grinalda de folhas de murta (MAR/038), a um fragmento de asa (MAR/295) e a ânforas do tipo Pellicer B/C e 11.2.1.3 de Ramon Torres, sugerindo igualmente uma cronologia de finais do século $V$ a.n.e.

Mas este tipo de kylix foi ainda usado em Castro Marim durante a primeira metade do século IV a.n.e., como provam MAR/119, recolhida no Quadrado E 02 Nível 07, juntamente com um skyphos de verniz negro de dupla curvatura (MAR/146) e um bordo de uma pátera da forma Lamboglia 22 (MAR/164), e MAR/050 recuperada no nível 3 do Quadrado C04, encontrada juntamente com dois fragmentos de taças Cástulo (MAR/095 e MAR/096), mas também com outros dois das formas Lamboglia 22 (MAR/161 e MAR/163), um da 23 (MAR/202) e outros ainda indeterminados (MAR/247 e MAR/272). A decoração de MAR/112, constituída por linhas incisas que se cruzam, pode também fazer avançar para a primeira metade do século IV a.n.e. o uso destes vasos no sítio da foz do Guadiana. Esta cronologia para estas taças não surpreende, dada a sua presença no depósito de Zacatín (Adroher Auroux - Sanchéz Moreno - Torre Castellano 2016), havendo também em Lattes dados estratigráficos que a confirmam, mesmo para a decoração que atrás referimos (Py - Adroher Auroux - Sanchez 2001: 361-3).

\section{Catálogo}

MAR/112 - C. Mar. 2002 Sector 01 [0584] 6252. Fragmento de fundo, pé e arranque de parede. A face interior do fundo exibe decoração composta de círculos incisos a delimitar linhas parcialmente intercessionadas. A superfície externa do fundo apresenta decoração composta por 


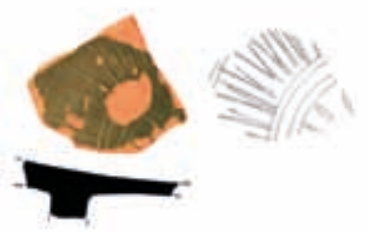

MAR/112

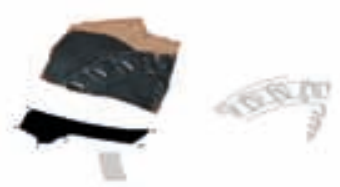

MAR/113

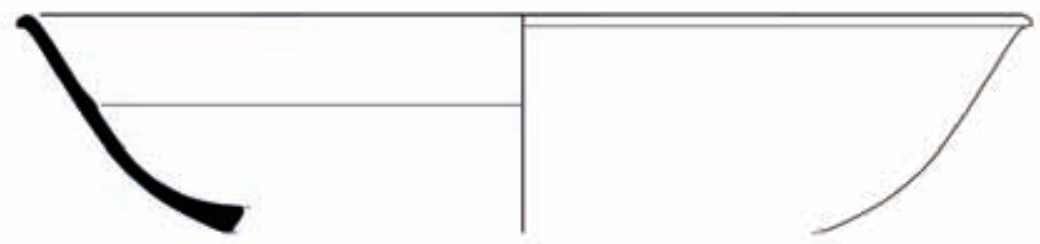

MAR/114

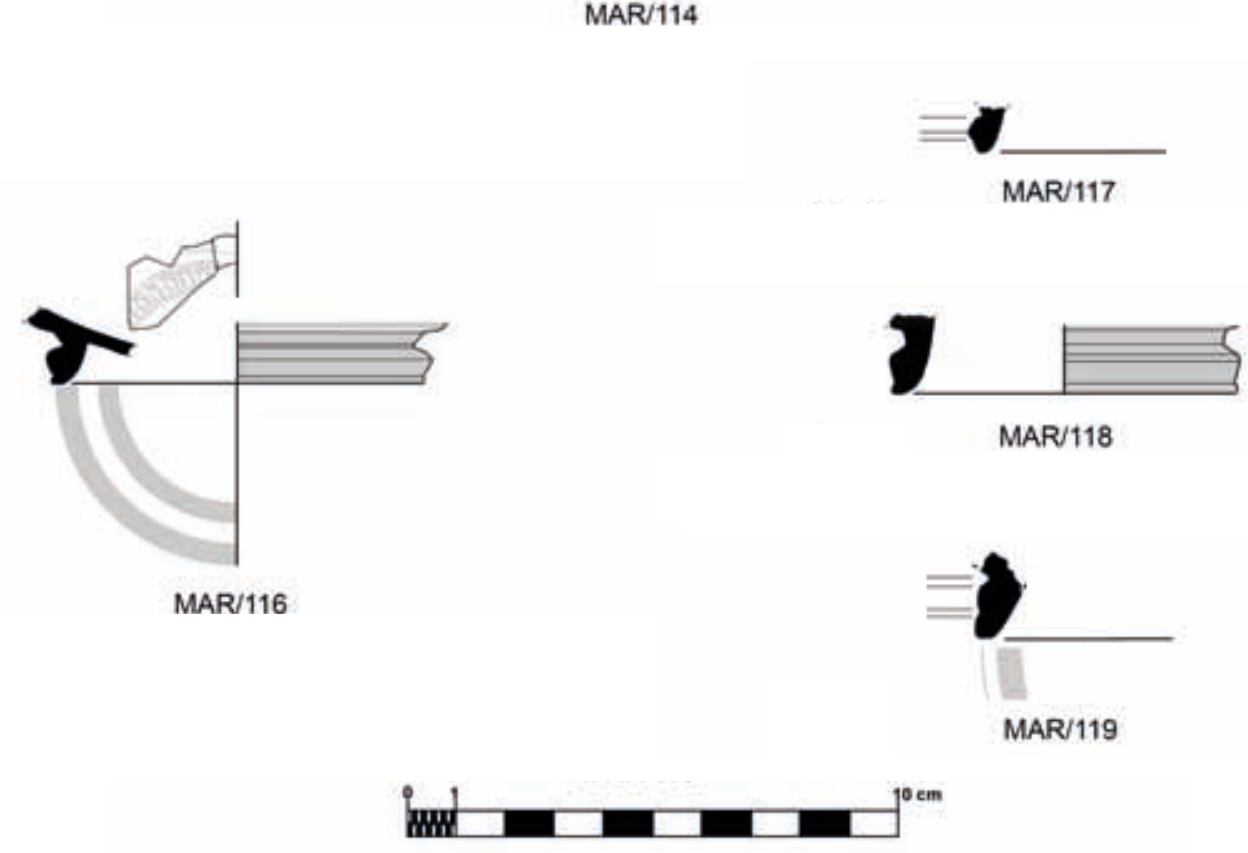

Fig. 24 - Taças da Classe Delicada de cerâmica ática de verniz negro do século V a.n.e.

círculos concêntricos de verniz negro. Pasta de cor bege, pouco compacta e muito depurada. Verniz negro, pouco brilhante e muito deteriorado.

MAR/113 - C. Mar. 2003 Sector 01 [0679] 2798. Fragmento de fundo e arranque de parede. O fundo interno apresenta decoração composta de vestígios de palmeta e banda de óvulos, delimitado por círculos concêntricos. O fundo externo exibe círculo em verniz negro.

MAR/114 - C. Mar. 2002 Sector 01 [0360] 3960; C. Mar. 2002 Sector 01 [0584] 7145; C. Mar. 2002 Sector 01 [0453] 4938. Três fragmentos pertencentes à mesma peça, correspondendo a bordo, parede e arranque de pé. A ligação do pé à parede é feita através de um ressalto pronunciado. Apresenta-se totalmente envernizado. Pasta de cor bege, dura, compacta e depurada. Verniz negro, aderente, espesso e brilhante. Diâmetro de bordo: $20,5 \mathrm{~cm}$. 
MAR/115 - C. Mar. 2000 Sector 01 [0052] 1325. Fragmento de pequena dimensão de bordo e parede. O bojo apresenta uma curvatura pronunciada. Pasta de cor bege e tonalidade alaranjada, dura, compacta e pouco depurada. Verniz negro, aderente, espesso e brilhante. Não ilustrado.

MAR/116 - C. Mar. 1987 Corte 03 Quadrado C 04 Nível 03 2784. Fragmento de arranque de parede, fundo e pé. Pé elevado, anelar e moldurado, apresentando a sua face interna convexa. A ligação do pé à parede é feita através de uma ranhura, seguida de uma garganta e um ressalto, este último deixado em reserva. O fundo interno é decorado com duas caneluras que delimitam dois círculos concêntricos de óvulos impressos. A superfície de apoio do pé é reservada. Fundo externo decorado com dois círculos concêntricos em reserva que alternam com círculo envernizado. Pasta de cor laranja e tonalidade acastanhada, dura, compacta e muito depurada. Verniz negro, aderente, espesso, muito brilhante e acetinado. Diâmetro de pé: 7,2 mm. Bibliografia: Arruda 1997: 123-124.

MAR/117 - C. Mar. 2002 Sector 01 [0089] 8011. Fragmento de pé. Pé anelar e moldurado, com a face interna convexa. Apresenta-se totalmente envernizado. Pasta de cor laranja clara, dura, compacta e depurada. Verniz negro, aderente, espesso e brilhante.

MAR/118 - C. Mar. Sup. sem n. ${ }^{\circ} 14$. Dois fragmentos com colagem entre si, correspondendo a pé e arranque de parede. Pé anelar, moldurado, com a face interna convexa. A ligação do pé à parede é feita através de uma garganta seguida de um ressalto. Apresenta-se totalmente envernizado. Pasta de cor laranja clara, dura, compacta e depurada. Verniz negro, de brilho muito metalizado, com manchas ligeiramente mais baças. O verniz é espesso e aderente.

MAR/119 - C. Mar. 1984 Corte 01 Quadrado E 02 Nível 07 2796. Fragmento de pé e arranque de parede. Pé anelar e moldurado. A superfície de apoio do pé encontra-se reservada. Pasta de cor laranja, dura, compacta e depurada. Verniz negro, pouco aderente, espesso e baço. Bibliografia: Arruda 1997: 129, fig. 2:7.

\subsubsection{As plain rim cups}

A terceira variante de taças de pé baixo identificada está representada por cinco fragmentos - cinco indivíduos, que, contudo, podem corresponder a apenas três vasos, uma vez que três dos fragmentos foram recolhidos na mesma unidade estratigráfica e, apesar de não ter sido possível “colá-los", parecem ter pertencido à mesma peça. Trata-se de vasos cujo bordo se liga ao pé através de uma única curvatura, ininterrupta, correspondendo os exemplares de Castelo de Castro Marim às taças «plain rim cup type (» da Ágora de Atenas (Sparkes - Talcott 1970: 92, n 432-433).

Semelhantes às taças Cástulo (inset lip), no respeitante ao pé, asas e dimensões gerais, acompanham a evolução crono-tipológica destas últimas, tendo sido, no entanto, menos populares.

As plain rim cups são formas típicas do século V a.n.e., tal como ficou comprovado na Ágora de Atenas (Ibidem), mas também, no que à Península Ibérica diz respeito, em Cancho Roano (Gracia Alonso 2003: 37, 131, lámina 11). A sua presença é sempre escassa nos sítios peninsulares com níveis datados dos dois últimos quartéis do século $V$ a.n.e., mas onde existem, por exemplo no Cerro del Prado (Cabrera - Perdigones 1996), Castillo de Doña Blanca (Cabrera 1997) e em Cancho Roano (Gracia Alonso 2003) aparecem juntamente com as taças da classe delicada e Cástulo.

Todos os fragmentos de plain rim cup de Castro Marim foram recolhidos em níveis conservados da Idade do Ferro. Para além das três peças da U.E. [0078=0089], já referida anteriormente e datada dos finais do século $V$ a.n.e., e que poderão ou não corresponder a um único vaso (MAR/122, MAR/123 e MAR/124), um outro fragmento desta forma (MAR/121) foi recolhido num nível de derrube de cronologia semelhante (U.E. [0602]). O estrato (U.E. [0546]), onde se recolheu o último (MAR/120), é já de cronologia posterior (primeira metade do século IV a.n.e.), uma vez que se sobrepõe a um outro que proporcionou fragmentos de cerâmica ática de figuras vermelhas 
atribuídos ao Pintor de Viena 116. Neste caso, deverá tratar-se de uma peça residual, considerando que esta forma já não seria produzida durante este período, ainda que não se possa descartar a possibilidade de, neste centro de consumo, o período de amortização deste tipo de recipientes possa ser mais prolongado.

\section{Catálogo}

MAR/120 - C. Mar. 2002 Sector 01 [0546] 6046. Fragmento de bordo. Lábio recto, estreitado. Apresenta um perfil de lábio e parede muito semelhante ao fragmento MAR/8093, ainda que este último registe características diferentes no respeitante à pasta. É possível que se trate do mesmo individuo. Apresenta-se totalmente envernizado. Pasta de cor laranja, dura, depurada, compacta e depurada. Verniz negro, aderente, brilhante, de boa qualidade. Diâmetro de bordo: $15 \mathrm{~cm}$.

MAR/121 - C. Mar. 2003 Sector 01 [0602] 10158. Fragmento de bordo. Lábio recto. Apresenta-se totalmente envernizado. Pasta de cor bege e tonalidade acinzentada, dura, compacta e depurada. Verniz negro, aderente, espesso e brilhante. Diâmetro de bordo: $17,9 \mathrm{~cm}$.

MAR/122 - C. Mar. 2000 Sector 01 [0089] 0888. Fragmento de bordo. Pasta de cor laranja e tonalidade acinzentada, dura, compacta e depurada. Verniz negro, aderente, brilhante, de boa qualidade.

MAR/123 - C. Mar. 2000 Sector 01 [0089] 0889. Fragmento de bordo e parede. Lábio recto, estreitado. É decorado na superfície interna por três pontos brancos, sobrepintados. Pasta de cor bege e tonalidade acinzentada, dura, compacta e depurada. Verniz negro, espesso, aderente e muito brilhante.
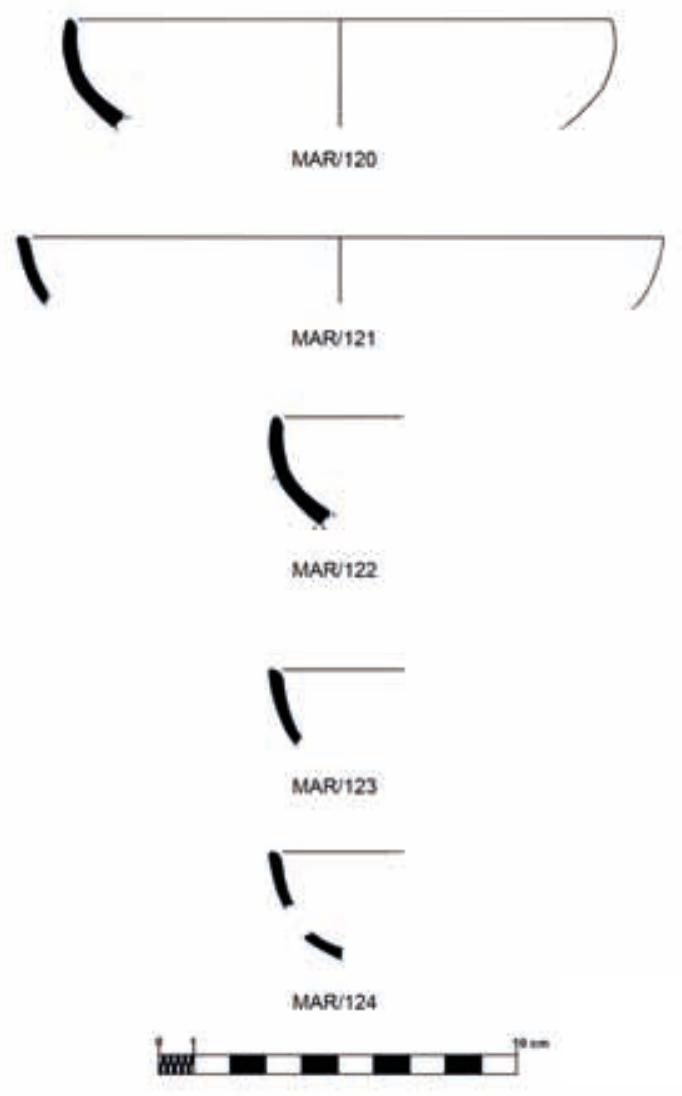

Fig. 25 - Kilikes de cerâmica ática de verniz negro (plain rim cup type C) do século V a.n.e. 
MAR/124 - C. Mar. 2000 Sector 01 [0089] 0887. Fragmento de bordo e parede. Lábio recto, estreitado. Apresenta-se totalmente envernizado. Pasta de cor cinzenta, dura, compacta e depurada. Verniz negro, aderente, espesso, muito brilhante e de boa qualidade. Diâmetro de bordo: $24,8 \mathrm{~cm}$.

\subsubsection{As stemless cups}

Dezasseis fundos e pés (sete indivíduos) foram incorporados no grande grupo das stemless cups da Ágora de Atenas, sem que tenha sido possível concluir sobre a sua inclusão em qualquer um dos tipos específicos destas taças sem pé, inset lip, plain rim ou delicate class, ainda que a grande maioria deva ter pertencido ao primeiro.

Dez dos fragmentos classificados como stemless cups foram recolhidos em níveis conservados da Idade do Ferro.

Alguns destes foram exumados na U.E. [0078=0089] (MAR/126, MAR/131, MAR/134) e na U.E. [0766] (MAR/139), já caracterizadas anteriormente e datadas do final do século $V$ a.n.e. A mesma cronologia poderá ser também atribuída à U.E. [0595], um pavimento que proporcionou um fragmento de uma outra stemless cup (MAR/133), e à U.E. [0734], correspondente a uma área de acumulação de detritos e carvões, onde surgiu um outro fragmento desta forma (MAR/137), associado a um bolsal (MAR/141). A esta mesma fase poderá ainda pertencer o nível 5 do Quadrado D4, onde a peça $M A R / 138$ surge associada a uma ânfora do tipo Pellicer $B / C$.

Outros fragmentos foram recolhidos em contextos datados já da primeira metade do século IV a.n.e. (U.E. [0545/0578] - MAR/128), em associação a cerâmica ática de figuras vermelhas, como já foi anteriormente referido. Também a peça MAR/129, recolhida na U.E. [0616], correspondente a um estrato de aterro/derrube, surgiu associada a um fragmento da forma Lamboglia 21/25B (MAR/216), sugerindo uma datação também centrada na primeira metade do século IV a.n.e. O mesmo se aplica à U.E. [0380], onde dois fragmentos de stemless cup (MAR/127 e MAR/136) surgem associados a uma ânfora de tipo Pellicer $\mathrm{B} / \mathrm{C}$ e a pequenas cabeças de vidro que representam uma divindade feminina, podendo integrar-se também neste caso numa cronologia da primeira metade do século IV a.n.e. (Arruda 2014).

\section{Catálogo}

MAR/125 - C. Mar. 2002 Sector 01 [0360] 6058. Fragmento de fundo, pé e parede. Pé anelar, moldurado. A superfície de apoio do pé encontra-se em reserva. Fundo externo decorado de círculos concêntricos em verniz negro e em reserva, alternados. Pasta de cor bege, dura, compacta e pouco depurada. São visíveis desengordurantes de pequeno calibre. Verniz negro, aderente, pouco espesso e brilhante. O verniz apresenta-se muito deteriorado na superfície interior do fundo. Diâmetro de pé: $8,9 \mathrm{~cm}$.

MAR/126 - C. Mar. 2002 Sector 01 [0089] 7230. Fragmento de pé. Pé anelar com a face interna convexa. A superfície de apoio do pé encontra-se em reserva. Pasta de cor bege, dura, compacta e depurada. Verniz negro, aderente, espesso e brilhante. Diâmetro de pé: $9,3 \mathrm{~cm}$.

MAR/127 - C. Mar. 2002 Sector 01 [0380] 6026. Fragmento de fundo, pé e parede. Pé anelar, moldurado. Apresenta a superfície de apoio em reserva. O fundo interno apresenta-se decorado com círculos em verniz negro e círculos em reserva, alternados. Pasta de cor laranja clara, dura, compacta e depurada. Verniz negro com manchas acinzentadas, aderente, espesso e brilhante. Diâmetro de pé: $8,6 \mathrm{~cm}$.

MAR/128 - C. Mar. 2002 Sector 01 [0578] 15594. Fragmento de pé, fundo e parede. Pé anelar, moldurado. Encontra-se totalmente envernizado. Pasta de cor laranja, dura, compacta e depurada. Verniz negro, aderente, espesso e brilhante. Diâmetro de pé: $9 \mathrm{~cm}$. 

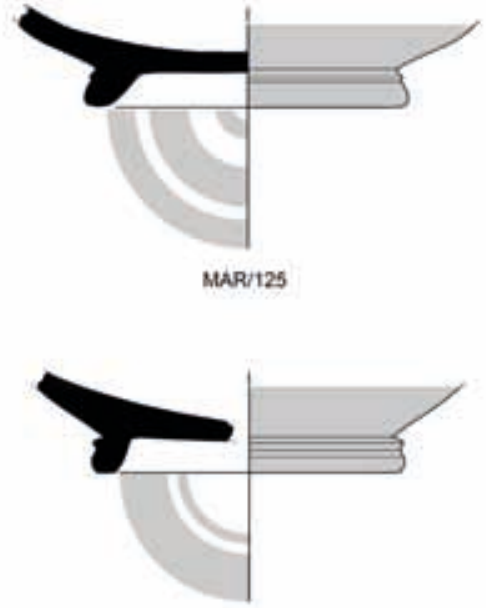

MAR/127

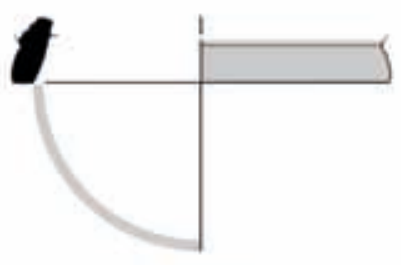

MARU129

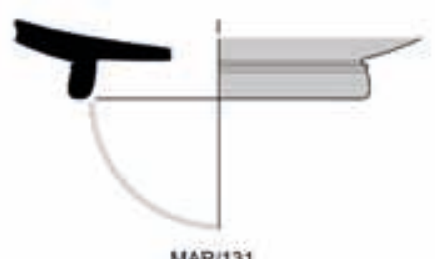

MAR/131

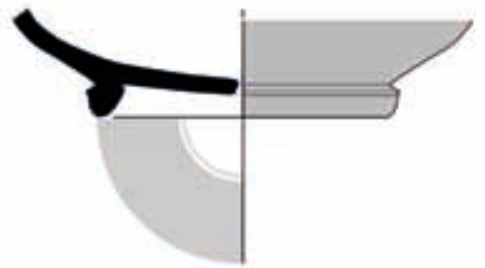

MAR/133
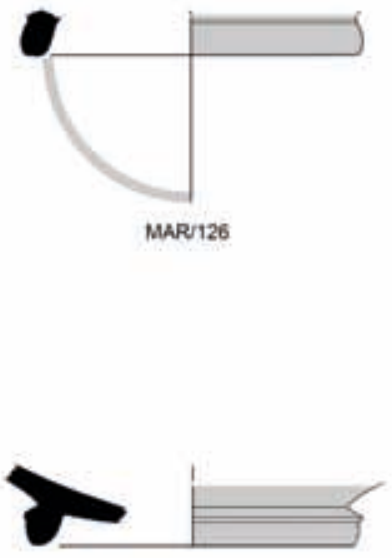

MAR/12月

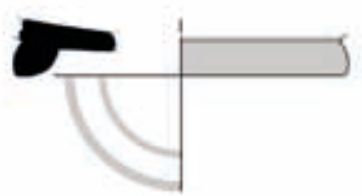

MAR/130
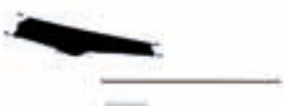

MAR/132

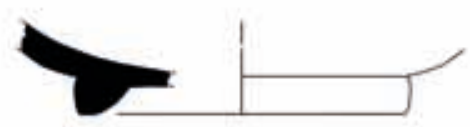

MAR/134

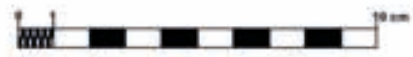

Fig. 26 - Fundos e pés de stemless cups de cerâmica ática de verniz negro do século V/IV a.n.e. 

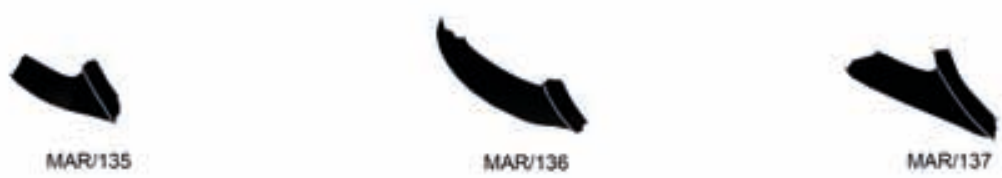

MARI35

MARU136

MAR/137

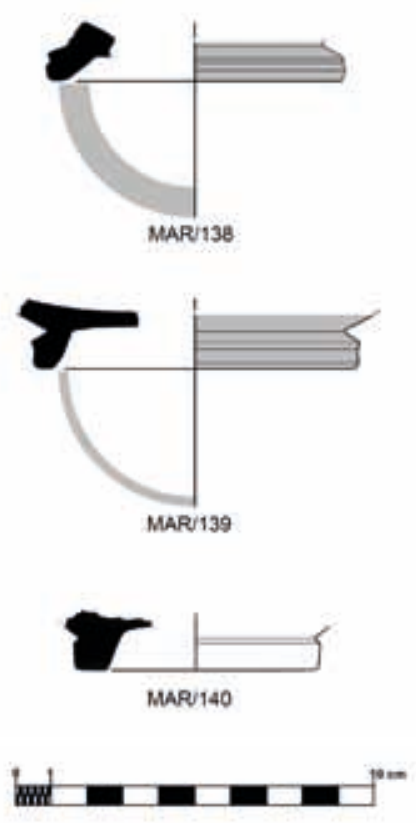

Fig. 27 - Asas, fundos e pés de stemless cups de cerâmica ática de verniz negro do século V/IV a.n.e.

MAR/129 - C. Mar. 2003 Sector 01 [0616] 11631. Fragmento de pé. Pé anelar. A superfície de apoio do pé encontra-se em reserva. Pasta de cor laranja, depurada e compacta. Verniz negro, aderente, pouco espesso e brilhante. Diâmetro de pé: 10,6 cm.

MAR/130 - C. Mar. Sup. 2794. Fragmento de fundo e pé. Pé anelar. O avançado estado de deterioração do verniz não permite confirmar se a superfície de apoio do pé se encontrava reservada. Fundo externo em reserva, decorado com círculos concêntricos em verniz negro e em reserva, alternados. Pasta de cor laranja, dura, compacta e pouco depurada. Verniz negro, aderente, espesso e muito brilhante. Diâmetro de pé: $9,2 \mathrm{~cm}$.

MAR/131 - C. Mar. 2000 Sector 01 [0089] 0878; C. Mar. 2000 Sector 01 [0089] 6093; C. Mar. 2002 Sector 01 [0570] 6098. Cinco fragmentos pertencentes à mesma peça, correspondendo a parede, fundo e pé. Fundo externo em reserva com círculo envernizado. Pasta de cor bege e tonalidade alaranjada, dura e compacta. Verniz negro, aderente, espesso e muito brilhante. O verniz é de boa qualidade e apresenta incrustações na face interna do fundo. Diâmetro de pé: 8,4 cm.

MAR/132 - C. Mar. 2002 Sector 01 [0385] 6072. Fragmento de pé. Apresenta-se totalmente envernizado. Pasta de cor laranja, dura, compacta e depurada. Verniz negro, muito deteriorado. Diâmetro de pé: $14,2 \mathrm{~cm}$. Não ilustrado.

MAR/133 - C. Mar. 2002 Sector 01 [0595] 6189. Quatro fragmentos com colagem entre si, correspondendo a parede, fundo e pé. Pé anelar, moldurado. Fundo externo decorado com círculos concêntricos em verniz negro e em reserva, alternados. Pasta de cor bege e tonalidade 
alaranjada, dura, compacta e muito depurada. Verniz negro, aderente, espesso, muito brilhante e de muito boa qualidade. Diâmetro de pé: $8,4 \mathrm{~cm}$.

MAR/134 - C. Mar. 2002 Sector 01 [0089] 7434. Fragmento de parede, fundo e pé. Pasta de cor bege, dura, compacta e depurada. Não conserva verniz. Diâmetro de pé: 9,6 cm.

MAR/135 - C. Mar. 2002 Sector 01 [0360] 6015. Fragmento de parede e asa de kylix. Asa de perfil oval. O Interior da asa apresenta-se reservado. Pasta de cor laranja, dura, compacta e depurada. Verniz negro com manchas avermelhadas, muito deteriorado.

MAR/136 - C. Mar. 2002 Sector 01 [0380] 6028. Fragmento de parede e asa de kylix. O interior da asa apresenta-se reservado. Pasta de cor laranja, dura, compacta e depurada. Verniz negro, aderente, espesso e brilhante.

MAR/137 - C. Mar. 2003 Sector 01 [0734] 10100. Fragmento de parede e asa de kylix. O interior da asa apresenta-se reservado. Pasta de cor laranja, dura, compacta e depurada. Verniz negro, aderente e pouco espesso.

MAR/138 - C. Mar. 1987 Corte 03 Quadrado D 04 Nível 05 2789. Fragmento de fundo, pé e parede. Pé anelar e moldurado. Apresenta superfície de apoio e face externa do pé em reserva. Pasta de cor laranja clara, dura, compacta e depurada. Verniz negro, aderente, espesso e brilhante. Diâmetro de pé: $8,1 \mathrm{~cm}$.

MAR/139 - C. Mar. 2003 Sector 01 [0766] 10074. Fragmento de fundo, pé e arranque de parede. Pé anelar e moldurado. Apresenta a superfície de apoio do pé em reserva. Pasta de cor laranja, dura, compacta e depurada. Verniz negro, espesso, aderente e brilhante. Diâmetro de pé: 8,9 cm.

MAR/140- C. Mar. Sup. sem n. ${ }^{15}$. Castelo de Castro Marim. Fragmento de pé, arranque de fundo e arranque de parede. Pasta de cor bege, dura, compacta e depurada. Verniz muito deteriorado, praticamente inexistente. Diâmetro de pé: $6,6 \mathrm{~cm}$.

\subsubsection{Os bolsais (Lamboglia $42 \mathrm{~B}-\mathrm{a}$ )}

Um reduzido grupo de taças (cinco fragmentos - cinco indivíduos) foi incluído no grupo dos bolsais (MAR/141 a MAR/145), um dos quais (MAR/145), dado o seu diâmetro e outros detalhes, foi assim considerado, mas com muitas reservas.

Todos apresentam verniz que se destaca dos demais materiais áticos identificados, pela sua boa qualidade, brilho e aderência. As peças caracterizam-se pela marcada concavidade na ligação da parede ao pé, na superfície exterior. Esta inflexão surge por vezes associada a uma fina banda reservada. A generalidade dos fragmentos corresponde aos marcadores tipológicos conhecidos para esta forma, em particular os que se aplicam a produções dos últimos anos do século $\mathrm{V}$ a.n.e., com paralelo na forma $n^{\circ} 557$ da Ágora de Atenas (Sparkes - Talcott 1970: 107, n 532-561, pls. 24, 53, fig. 6, 22), destacando-se entre eles a presença da curvatura única da parede, atingindo o seu diâmetro máximo no bordo, ou imediatamente abaixo dele, por oposição à dupla curvatura que caracteriza as peças produzidas na centúria seguinte (Sparkes - Talcott 1970: 107).

A forma começou a fabricar-se no último quartel do século V a.n.e. (Sparkes - Talcott 1970: 107), sendo raríssima antes de 400 a.n.e. fora da Grécia. Nunca tendo alcançado um grande sucesso, foi 
produzida, pelo menos até 350 a.n.e. Na Península Ibérica, está bem documentada no Nordeste, concretamente em Ampúrias, Levante e Andaluzia, mas nunca em quantidades significativas (Trías 1967-1968; Rouillard 1991), não deixando de surpreender os 40 exemplares que incorporavam a carga da embarcação que naufragou em El Sec (Arribas et al. 1987). Em Portugal, este tipo de taça está mal representado nos sítios arqueológicos que consumiram cerâmica grega durante o século IV a.n.e., devendo referir-se, na fachada ocidental, os exemplares únicos de Lisboa (Arruda - Sousa, 2018) e do Cabeço Guião, Cartaxo (Arruda et al. 2017), bem como os três da necrópole do Senhor dos Mártires, em Alcácer do Sal (Rouillard et al. 1988-1989). No Algarve, e para além de Castro Marim, os bolsais foram reconhecidos no Cerro da Branca (Gomes et al. 1986: 89) e em Monte Molião (Arruda et al. 2011).

Dos cinco fragmentos de bolsais recolhidos durante as campanhas de escavação, três são provenientes de contextos conservados da Idade do Ferro.

Um deles (MAR/141) foi exumado numa área de acumulação de detritos e carvões (U.E. [0734]), estando associado a uma stemless cup (MAR/137), datada do final do século $V$ a.n.e.

Do final do século $V$ ou inícios do século IV a.n.e. será a U.E. [0588], correspondente a um nível de pavimento, no qual foi recolhido o fragmento MAR/145.

Um outro (MAR/144), recuperado na U.E. [0041], está associado a cerâmicas de tipo Kuass, o que obriga a considerar uma cronologia da formação deste estrato num momento posterior à segunda metade do século IV a.n.e.

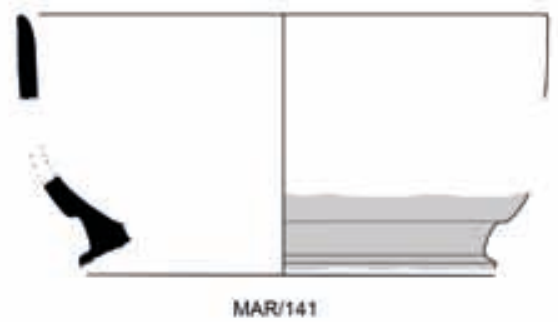

MAR/141
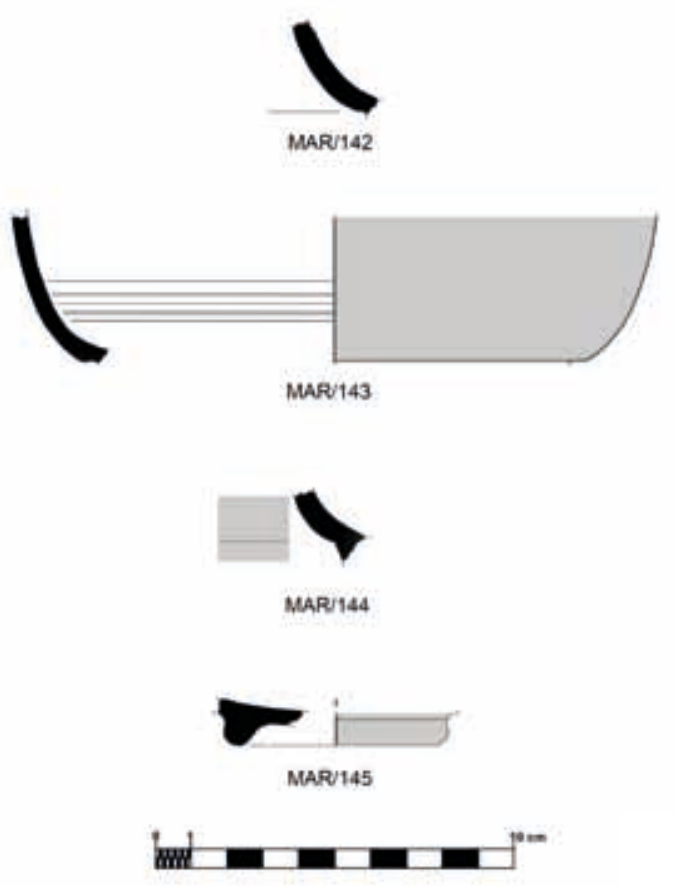

Fig. 28 - Bolsais de cerâmica ática de verniz negro do século V/IV a.n.e. 


\section{Catálogo}

MAR/141 - C. Mar. 2003 Sector 01 [0734] 10101; C. Mar. 2003 Sector 01 [0405] 15576; C. Mar. 2002 Sector 01 [0447] 6078; C. Mar. 2003 Sector 01 [Sup.] 8009. Conjunto de sete fragmentos pertencentes à mesma peça, correspondendo a bordo, parede, arranque de pé e fundo. Bordo de lábio recto, afilado na extremidade. A ligação do pé á parede é feita, na superfície externa, através de um ressalto pronunciado, antecedido de uma banda em reserva. Pasta de cor laranja, dura e compacta. Verniz negro com manchas de tonalidade acinzentada, aderente, espesso e baço. O Verniz apresenta um ligeiro brilho metalizado. Diâmetro de bordo: 14,7 cm.

MAR/142 - C. Mar. 2002 Sector 01 [0360] 3966. Fragmento de parede e arranque de pé. A ligação do pé á parede é feita, na superfície externa, através de um ressalto pronunciado. Pasta de cor bege, dura, compacta e depurada. Verniz negro, aderente, espesso, muito brilhante e de muito boa qualidade.

MAR/143 - C. Mar. 2000 Sector 01 [Sup.] 0014. Fragmento de parede e arranque de pé. A ligação do pé á parede é feita, na superfície externa, através de um ressalto pronunciado. Pasta de cor bege, dura, compacta e depurada. Verniz negro, aderente, espesso e muito brilhante.

MAR/144 - C. Mar. 2000 Sector 01 [0041] 1098. Fragmento de parede e arranque de pé. A ligação do pé á parede é feita, na superfície externa, através de um ressalto pronunciado, antecedido por uma banda em reserva. Apresenta uma linha em reserva na superfície externa, na ligação do pé à parede. Pasta de cor bege, dura, compacta e depurada. Verniz negro, aderente, espesso e muito brilhante.

MAR/145 - C. Mar. 2002 Sector 01 [0588] 6082. Fragmento de pé, fundo e arranque de parede. Pé baixo, de perfil arredondado, simples, e com ambas as faces convexas. A classificação como bolsal deve ser considerada com reserva. Pasta de cor bege, dura, compacta e depurada. Verniz negro, espesso e brilhante. $O$ avançado estado de deterioração do verniz não permite confirmar se existem áreas em reserva. Diâmetro de fundo: $6,26 \mathrm{~cm}$.

\subsubsection{Os skyphoi (Lamboglia 43)}

São sete os fragmentos (sete indivíduos) de cerâmica grega do Castelo de Castro Marim que foram inclú́dos neste tipo. Sendo uma forma consideravelmente arcaica, tendo-se produzido em Corinto desde o século VIII a.n.e., o seu fabrico prolongou-se nas oficinas áticas que também a fabricaram até à centúria seguinte. A sua evolução morfológica foi devidamente entendida nas escavações da Ágora de Atenas (Sparkes - Talcott 1970: 84-85), tendo ficado claro que, até ao final do século $V$ a.n.e., o corpo do vaso é completamente ovoide, havendo uma linha contínua do bordo ao fundo. A partir do século IV a.n.e., as paredes descrevem uma dupla curvatura, o que resulta num vaso de paredes com dupla convexidade e bordo evertido. Esta mesma realidade foi confirmada em Lattes (Py - Adroher Auroux - Sanchez 2001: 345-350) e em outros contextos, mesmo peninsulares.

Em Castro Marim, os dois bordos (MAR/146 e MAR/147) correspondem às duas variantes anteriormente referidas, e como veremos já de seguida, a cronologia dos contextos que thes estão associados estão de acordo com a evolução morfológica atrás sumariamente apresentada.

Dos sete fragmentos, cinco são provenientes de níveis conservados da Idade do Ferro.

Um deles (MAR/149) surgiu num nível datado de finais do século $V$ a.C. (U.E. [0766]) conjuntamente com fragmentos de Taças Cástulo (MAR/053, MAR/065, MAR/091), um fundo de uma stemless cup (MAR/139) e também vários exemplares de ânforas tipo Pellicer B/C e Maña Pascual A4 (variante 11.2.1.3 de Ramon Torres).

De finais do século $V$ a.n.e. é o nível 05 do Quadrado E 10, no qual se recolheu um dos 


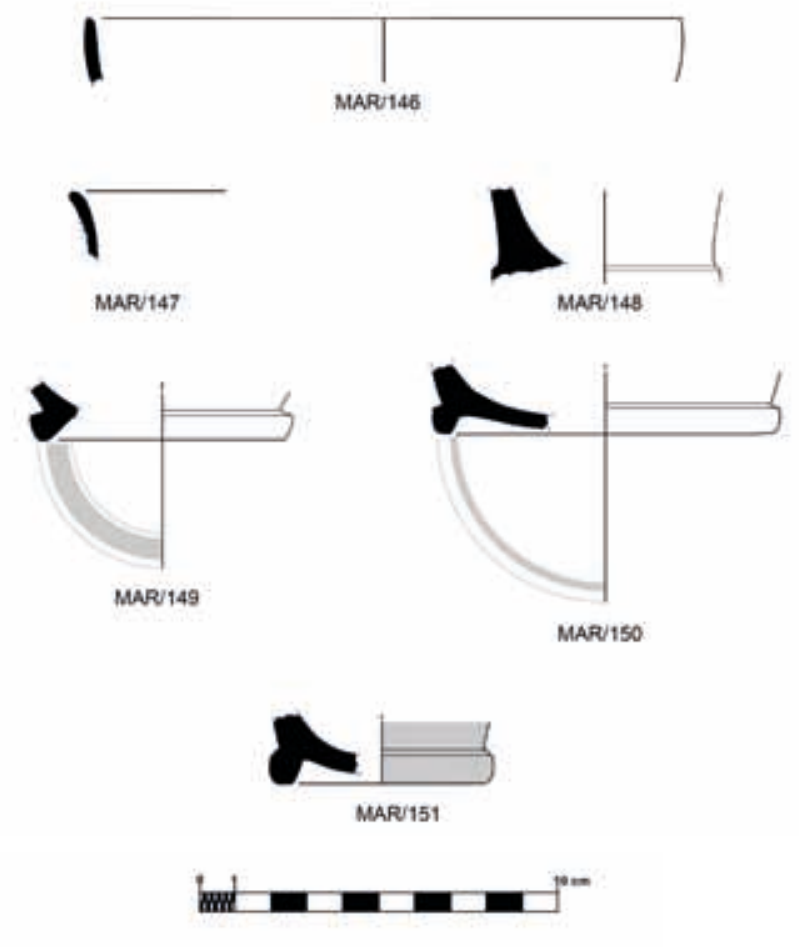

Fig. 29 - Skyphoi de cerâmica ática de verniz negro do século V/IV a.n.e.

fragmentos de skyphoi (MAR/146) em associação a uma taça Cástulo (MAR/o86). Desta mesma cronologia é o nível de derrube/entulhamento (U.E. [0658]), no qual se recolheu a peça MAR/150. Um outro (MAR/147) foi recolhido no Quadrado E 02 Nível 07, em associação a uma taça da Classe Delicada (MAR/119) e a um bordo de uma pátera da forma Lamboglia 22 (MAR/164), sendo este nível datado da primeira metade do século IV a.n.e.

Por último, resta referir a recolha de um skyphos (MAR/151) no nível 04 do Quadrado E 03, em associação a outros fragmentos de cerâmica grega da forma Lamboglia 21/22 (MAR/171, MAR/176, MAR/186 e MAR/193), taças Cástulo (MAR/105), pratos de peixe (MAR/197), asas de forma indeterminada (MAR/285 e MAR/287), mas também a cerâmicas de tipo Kuass, ânforas do tipo Pellicer B/C e D, Maña Pascual A4 (séries 11 e 12 de Ramon Torres) e Tiñosa (8.1.1.2), indicando uma cronologia de formação da camada posterior ao terceiro quartel do século IV a.n.e.

Os skyphoi são bastante comuns na Península Ibérica entre os finais do século $\mathrm{V}$ e a primeira metade do século IV a.n.e. (Trías 1967-1968; Rouillard 1991), mas, em Portugal, não são particularmente abundantes, estando os mais antigos, de curvatura única, documentados no Castelo de Alcácer do Sal (Silva et al. 1980-1981) e em Mértola (Arruda - Barros - Lopes 1998).

\section{Catálogo}

MAR/146 - C. Mar. 1984 Corte 01 Quadrado E 02 Nível 07 2799. Fragmento de bordo. Bordo recto. Pasta de cor bege e tonalidade alaranjada, dura, compacta e depurada. Verniz negro, aderente, muito espesso e brilhante. Diâmetro de bordo: $16,4 \mathrm{~cm}$.

MAR/147 - C. Mar. 1988 Corte 01 Quadrado E 10 Nível 05 2798. Fragmento de bordo com zona de arranque de asa imediatamente abaixo do lábio. Bordo de lábio esvasado. Pasta de cor laranja, dura, compacta e depurada. Verniz negro, aderente, espesso e baço. Bibliografia: Arruda 1997: 130 fig. 2: 9. 
MAR/148 - C. Mar. 1988 Corte 03 Quadrado E 05 Nível 01 2800. Fragmento de parede, fundo e pé. Pasta de cor cinzenta e tonalidade esverdeada, dura, compacta e depurada. Verniz negro, aderente, espesso e baço. Diâmetro do pé: $6 \mathrm{~cm}$.

MAR/149 - C. Mar. 2003 Sector 01 [0766] 10099. Fragmento de parede, fundo e pé. A superfície de apoio do pé foi deixada em reserva. Pasta de cor laranja e tonalidade rosa, dura, compacta e depurada. Verniz negro, aderente, espesso, brilhante, de boa qualidade. Diâmetro do pé: $6,8 \mathrm{~cm}$.

MAR/150 - C. Mar. 2003 Sector 01 [0658] 10122. Fragmento de parede, fundo e pé. Pé de perfil arredondado. A superfície de apoio do pé aparenta estar em reserva, ainda que o estado de deterioração do verniz não o permita confirmar. Pasta de cor bege e tonalidade alaranjada, dura, compacta e depurada. Verniz negro, com manchas de brilho metalizado na superfície externa. Verniz aderente, espesso e muito brilhante. Diâmetro do pé: 9,4 cm.

MAR/151 - C. Mar. 1983 Corte 01 Quadrado E 03 Nível 04 2801. Fragmento de parede, fundo e pé. Pé de perfil arredondado. A ligação do pé à parede é feita através de uma canelura em reserva. A superfície de apoio e o fundo externo apresentam-se em reserva. Pasta de cor bege, dura, compacta e depurada. Verniz negro, aderente, espesso e muito brilhante. Diâmetro do pé: $5,8 \mathrm{~cm}$.

MAR/152 - C. Mar. 2002 Sector 01 [Limpeza] 6031. Fragmento de fundo e pé. Muito fracturado e deteriorado. Pasta de cor bege, dura, compacta e depurada. Verniz muito deteriorado. Não ilustrado.

\subsubsection{Os kantharoi}

Com uma menor representação no cômputo geral das importações áticas de verniz negro, verifica-se igualmente a presença de kantharoi, tendo sido possível identificar três fragmentos que podem incluir-se globalmente nesta forma. Não obstante as dificuldades verificadas numa classificação tipológica mais específica, pensamos tratar-se, no caso dos bordos, de exemplares da forma kantharos-moulded rim, apresentando lábio moldurado, de sessão triangular-arredondado, com paralelos mais próximo nas peças nº 707-708 da Ágora de Atenas (Sparkes - Talcott 1970: 117).

Os fragmentos de pés, de difícil classificação, são moldurados, com mamilo central na superfície externa do fundo e estampilhas na interna. Considerando o arqueamento de um dos fragmentos de pé identificado, poderemos estar perante um exemplar de kantharos ou kylix-khantahos. Não obstante a imprecisão tipológica, as suas características formais sugerem que se trata de produções do segundo quartel do século IV a.n.e. A decoração presente numa destas peças é composta por vestígios de duas palmetas, curtas e despegadas, exibindo volutas e núcleo central. São unidas por caulículos a um círculo central, apresentando semelhanças com as características conhecidas para o taller Sec-10 do naufrágio de El Sec (Arribas et al. 1987).

Infelizmente, nenhum dos fragmentos do Castelo de Castro Marim assim classificados foi encontrado em contexto seguro.

\section{Catálogo}

MAR/153 - C. Mar. 1987 Corte 03 Quadrado C 05 Nível 01 2797. Fragmento de bordo. O lábio apresenta secção triangular, arredondada. Enquadra-se na forma kylix-kantharos, possivelmente do tipo «moulded rim». Pasta de cor laranja claro, dura, compacta e depurada. Verniz negro, aderente, espesso e brilhante. Diâmetro de bordo: 11,7 cm. Bibliografia: Arruda 1997: 129, fig. $2: 8$.

MAR/154 - C. Mar. 1987 Corte 03 Quadrado D 05 Nível 01 1646. Fragmento de bordo. O lábio apresenta secção triangular, arredondado. Enquadra-se na forma kylix-kantharos, possivelmente 

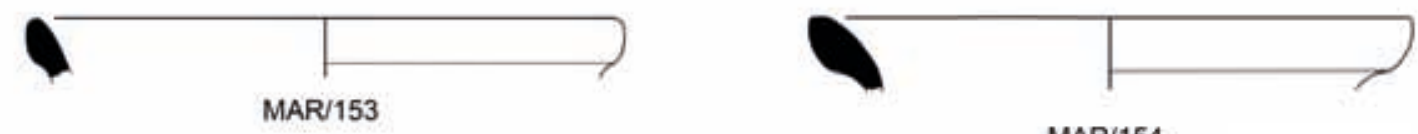

MAR/154

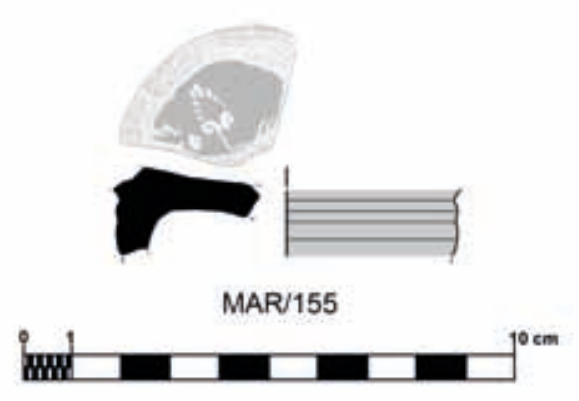

Fig. 30 - Kantharoi de cerâmica ática de verniz negro do século IV a.n.e.

do tipo «moulded rim». Pasta de cor laranja, dura, compacta e depurada. Verniz negro, aderente, espesso e brilhante. Diâmetro de bordo: $12,2 \mathrm{~cm}$.

MAR/155 - C. Mar. Sup. 2795. Fragmento de fundo e pé. Pé moldurado e ligeiramente arqueado. Enquadra-se na forma kantharos ou kylix-kantharos. O fundo interno apresenta-se decorado com vestígios de três palmetas de pétalas curtas e despegadas. As palmetas exibem volutas, estando ausente o núcleo central. Apresentam-se unidas por caulículos. Pasta de cor laranja, dura, compacta e depurada. Verniz negro com manchas de brilho metalizado. O verniz apresenta-se aderente, espesso e brilhante. Bibliografia: Arruda 1997: 129, fig. 2: 6.

\subsubsection{A mug}

Um fundo plano e reservado nas superfícies externa e interna pode ter correspondido ao que os investigadores da Escola Americana em Atenas designaram por Mug (Sparkes - Tacott 1970: 132, pls. 33-34, 59, figs. 9, 20, 22). Trata-se, seguramente, de um vaso fechado e a ligação do fundo à parede, com estrangulamento, sugere um corpo globular. Esta classificação é aqui avançada com as necessárias reservas, dada a dimensão do fragmento e também a ausência deste tipo de vaso no ocidente em geral e no território actualmente português em particular.

O contexto de recolha não permite adiantar quaisquer considerações de ordem cronológica a respeito da utilização desta peça no sítio da foz do Guadiana.

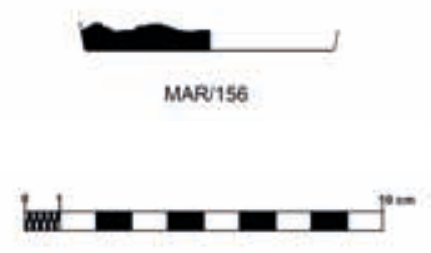

Fig. 31 - Mug de cerâmica ática de verniz negro. 
MAR/156 - C. Mar. 1984 Corte 03 Quadrado G 02 Nível 03 8759. Fragmento de fundo. A superfície de apoio apresenta-se reservada. Superfície externa totalmente envernizada. Pasta de cor bege e tonalidade alaranjada, dura, compacta e depurada. Verniz muito deteriorado, quase inexistente. Diâmetro de fundo: $7 \mathrm{~cm}$.

\subsubsection{As páteras da forma 21 (Incurving Rim Bowl)}

As páteras da forma 21 possuem bordos reentrantes e paredes muito encurvadas, e têm frequentemente decoração estampilhada no fundo interno. Os pés são arqueados e altos. De acordo com os dados da Ágora de Atenas, a sua produção iniciou-se na primeira metade do século IV a.n.e., ainda que se considere a possibilidade de derivarem de uma outra forma, arcaica e menos popular, criada no final do século V a.n.e. (Sparkes - Talcott 1970: 131). São bem conhecidas nos contextos habitacionais peninsulares, mas também em necrópoles, como é o caso concreto de El Cigarralejo, ou de Cabecito del Tesoro, ambas em Múrcia (Cuadrado 1963; García Cano 1982), e, em Portugal, na do Senhor dos Mártires, em Alcácer do Sal (Rouillard et al. 1988-1989). No ocidente, foram distribuídas conjuntamente com as kilikes de figuras vermelhas do pintor de Viena 116, como ficou claramente demonstrado no naufrágio de El Sec (Arribas et al. 1987), uma associação que o depósito de Zacatín também provou (Adroher Auroux - Sanchéz Moreno - Torre Castellano 2016, Rouillard - Torre Castellano - Sanchez Moreno 2017).

Dos dois fragmentos (dois indivíduos) seguramente pertencentes à forma 21 de Lamboglia, apenas um é proveniente de um nível conservado da Idade do Ferro (MAR/158). Foi recuperado no nível 6 do quadrado D 03, que parece corresponder a um estrato de ocupação, estando associado a fragmentos de cerâmica ática de verniz negro da forma Lamboglia 21/22 (MAR/179 e MAR/180), podendo um destes corresponder ao mesmo vaso. A cronologia proposta para este nível centrase na primeira metade do século IV a.n.e.

\section{Catálogo}

MAR/157 - C. Mar. Sup. 2802. Fragmento de bordo e parede. Bordo de lábio reentrante. Apresenta-se totalmente envernizado. Pasta de cor laranja, dura, compacta e depurada. Verniz negro, aderente, espeço e baço. Diâmetro de bordo: $17,5 \mathrm{~cm}$.

MAR/158 - C. Mar. 1985 Corte 01 Quadrado D 03 Nível 06 2809. Fragmento de bordo e parede. Bordo de lábio reentrante. Pasta de cor laranja, dura, compacta e depurada. Verniz negro, de tonalidade esverdeada, aderente e espesso. O verniz apresenta manchas avermelhadas e acastanhadas. Diâmetro de bordo: $22,3 \mathrm{~cm}$.

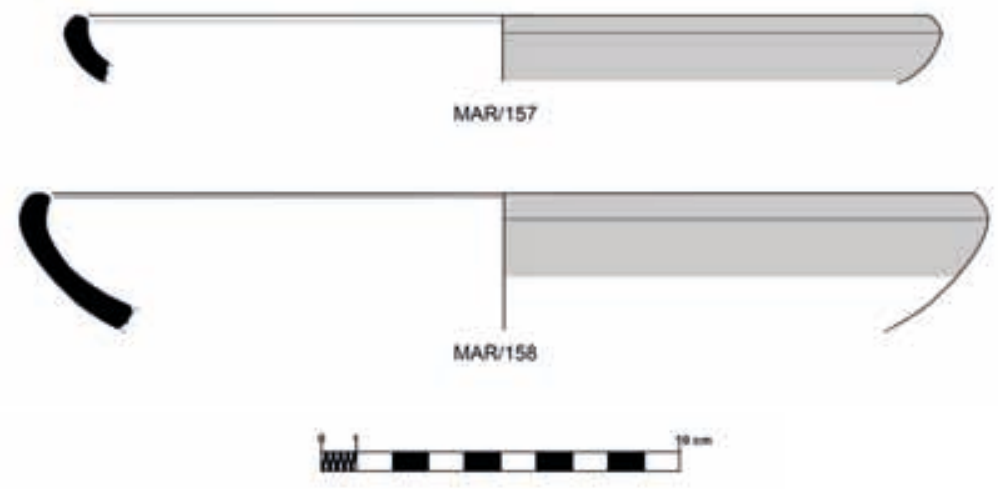

Fig. 32 - Páteras da forma 21 de Lamboglia de cerâmica ática de verniz negro do século IV a.n.e. 


\subsubsection{As páteras da forma 22 (Outturned Rim Bowl)}

As páteras de bordo evertido, ou forma 22 de Lamboglia, com uma cronologia de produção semelhante às da 21 da mesma tipologia, caracterizam-se pelo lábio ligeiramente engrossado e projectado para fora, sendo baixas e largas. No decorrer da sua evolução formal, adoptam ligeiras variações no respeitante ao bordo, corpo e pé. Regra geral, o pé torna-se mais alto e arqueado e o fundo externo perde a decoração de círculos e ponto sob área reservada, para dar lugar a fundos totalmente envernizados com mamilo central (Sparkes - Talcott 1970: 131-132). Também a parede regista alterações ao longo do tempo, verificando-se um perfil de curvatura única nas peças mais antigas, e uma dupla curvatura, nas mais tardias. Os exemplares de Castro Marim enquadram-se na forma canónica, havendo, contudo, um bordo, MAR/168, que é mais espesso e possui um perfil mais arredondado que os restantes.

Os dois tipos de pátera encontram-se frequentemente em associação, como é, em muitos outros, o caso do naufrágio da embarcação El Sec (Arribas et al. 1987), ou o da necrópole de El Cigarrralejo (Cuadrado 1963: 135), sítios em que ambos os tipos exibem idênticas características formais no respeitante aos pés, e similitudes no que diz respeito à qualidade e características do verniz e aos motivos decorativos (Arribas et al. 1987).

As páteras da forma 22 de Lamboglia do Castelo de Castro Marim, doze fragmentos-doze indivíduos, destacam-se pela particularidade de apresentarem uma banda em reserva, na superfície exterior, imediatamente a seguir ao lábio. Apenas quatro do conjunto de doze fragmentos recolhidos, não exibe este elemento decorativo.

Ambos os tipos de pátera (formas 21 e 22 de Lamboglia) apresentam, usualmente, decoração estampilhada na superfície interna do fundo. O padrão mais comum compõe-se por palmetas isoladas ou ligadas entre si através de caulículos, dispostas em um ou dois círculos. Estes motivos são normalmente complementados de um círculo central inciso e, em alguns exemplares, recorrese a bandas de óvulos para delimitar o conjunto decorativo, verificando-se a partir de 390/380 a. C., a substituição deste elemento por estrias feitas ao torno, como em Castro Marim se observa, por exemplo, em MAR/177, MAR/180 e MAR/181. Os motivos decorativos registados no Castelo de Castro Marim encontram correspondência com peças atribuídas aos talleres El Sec-8, El Sec-5 e El Sec-2 do naufrágio das Baleares (Arribas et al. 1987).

A forma 22 é, como já referimos, comum na maioria dos sítios peninsulares do Sul, Levante e Nordeste ocupados durante o século IV a.n.e., parecendo fazer sentido citar aqui os exemplares encontrados em território português, nomeadamente os das necrópoles de Alcácer do Sal (Rouillard et al. 1988-1989) e da Quinta da Queimada (Barros 2005, Calado - Gomes 2006), mas também os de Mértola (Arruda - Barros - Lopes 1998, Barros 2010), de Tavira (Barros 2003, 2005), do Castelo de Moura e da Azougada (Soares 2017), onde estão, quase sempre, associados, à forma 21.

Dos 12 fragmentos da forma Lamboglia 22 recuperados em Castro Marim, cinco são provenientes de níveis conservados da Idade do Ferro. Dois deles (MAR/161 e MAR/163) foram recuperados no nível 3 do Quadrado $\mathrm{C}$ 04, já referido anteriormente, pela sua associação a dois fragmentos de taças Cástulo (MAR/095 e MAR/096), a uma taça da Classe Delicada (MAR/116), a um prato de peixe (MAR/202), a alguns fragmentos indeterminados (MAR/247 e MAR/272) e a ânforas do tipo Pellicer $B / C$. A conjugação dos elementos cronológicos sugere uma datação deste estrato em torno à primeira metade do século IV a.n.e.

Um outro exemplar (MAR/164) surgiu no nível 07 do Quadrado E 02, estando associado a um fragmento de uma taça de Classe Delicada (MAR/119) e a outro de um skyphos (MAR/146), sendo a sua cronologia provavelmente idêntica à do caso anterior.

Mais tardio será o contexto de recolha da peça MAR/169, proveniente do Quadrado E 02, Nível 04. Apesar de associada a um fragmento de cerâmica ática de figuras vermelhas (MAR/031), a presença, neste mesmo contexto, de cerâmicas de tipo Kuass, ânforas do tipo Tiñosa (Ramon Torres 8.1.1.2) e Pellicer $D$, obriga a considerar uma cronologia para a sua formação posterior ao terceiro quartel do século IV a.n.e. 

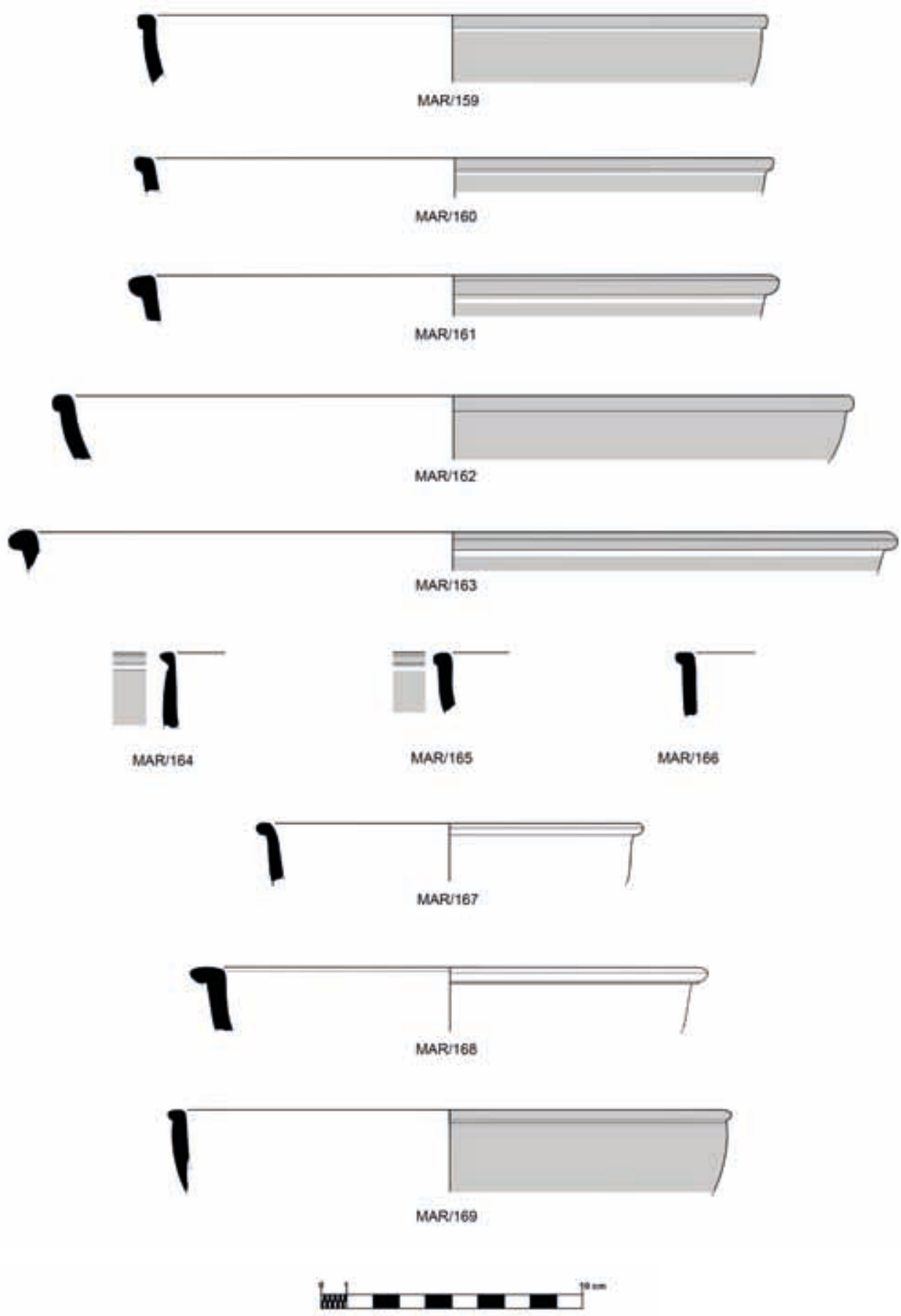

Fig. 33 - Páteras da forma 22 de Lamboglia de cerâmica ática de verniz negro do século IV a.n.e. 
A mesma situação aplica-se a MAR/170, recolhida na U.E. [0028/0035], que está, uma vez mais, acompanhada por cerâmica de tipo Kuass e ânforas do tipo Pellicer B/C. Contudo, deve destacar-se a associação, nesta camada, a outros fragmentos de cerâmica grega, concretamente um pelike de figuras vermelhas (MAR/041) e um de forma indeterminada de verniz negro (MAR/240).

\section{Catálogo}

MAR/159 - C. Mar. 2002 Sector 01 [0360] 3964. Fragmento de bordo e parede. Bordo de lábio arredondado e esvasado, formando um rebordo saliente. Apresenta uma banda em reserva na superfície exterior, imediatamente a seguir ao lábio. Pasta de cor laranja, compacta e depurada. Verniz negro com manchas avermelhadas. Diâmetro de bordo: 24 cm.

MAR/160-C. Mar.2002 Sector 01[0426]6049. Fragmento de bordo e parede. Lábio arredondado e esvasado, formando um rebordo saliente. Exibe uma banda em reserva na superfície externa. Pasta de cor laranja, compacta e depurada. Verniz negro, aderente, espesso e brilhante. Diâmetro de bordo: $24,4 \mathrm{~cm}$.

MAR/161 - C. Mar. 1987 Corte 03 Quadrado C 04 Nível 03 2805. Fragmento de bordo e parede. Lábio arredondado e esvasado, formando um rebordo saliente. Exibe uma banda em reserva na face exterior. Pasta de cor laranja, dura, compacta e depurada. Verniz negro, aderente e pouco espesso, particularmente na superfície externa. Diâmetro de bordo: $24,1 \mathrm{~cm}$.

MAR/162 - C. Mar. 2002 Sector 01[0360] 3959. Fragmento de lábio e parede. Lábio arredondado e exvasado, formando um rebordo saliente. Apresenta-se totalmente engobado. Pasta de cor laranja e tonalidade acinzentada, dura, compacta e depurada. Verniz negro, aderente, espesso e brilhante. Diâmetro de bordo: 30,42 cm.

MAR/163 - C. Mar. 1987 Corte 03 Quadrado C 04 Nível 03 2829. Fragmento de bordo e parede. Lábio arredondado e esvasado, formando um rebordo saliente. Exibe uma banda em reserva na superfície externa, com início no final do lábio. Pasta de cor laranja, dura, compacta e muito depurada. Verniz negro, aderente, espesso e brilhante. Diâmetro de bordo: 33,4 cm.

MAR/164 - C. Mar. 1984 Corte 01 Quadrado E 02 Nível 07 2804. Fragmento de bordo e parede. Lábio arredondado e esvasado, formando um rebordo saliente. Exibe uma canelura em reserva, imediatamente a seguir ao lábio. Pasta de cor laranja, dura, compacta e muito depurada. Verniz negro, aderente, espesso e brilhante.

MAR/165-C. Mar.2002 Sector 01[0520]6062. Fragmento de bordo e parede. Lábio arredondado e esvasado, formando um rebordo saliente. Exibe uma banda em reserva, imediatamente a seguir ao lábio. Pasta de cor laranja, dura, compacta e muito depurada. Verniz negro com manchas acastanhadas na superfície interior e avermelhadas na exterior. Na face externa, apresenta-se muito deteriorado e pouco espesso.

MAR/166 - C. Mar. 2002 Sector 01 [0360] 3957. Fragmento de bordo e parede. Lábio arredondado e esvasado, formando um rebordo saliente, faturado. Apresenta-se totalmente engobado. Pasta de cor laranja, dura, compacta e muito depurada. Verniz negro, aderente, pouco espesso na superfície externa.

MAR/167 - C. Mar. 1987 Corte 03 Quadrado D 05 Nível 01 1557. Fragmento de bordo e parede. Lábio arredondado e esvasado, formando um rebordo saliente. Apresenta-se totalmente engobado. Pasta de cor laranja e tonalidade acinzentada, dura, compacta e muito depurada. Verniz negro, aderente, espesso e brilhante. Diâmetro de bordo: $14,5 \mathrm{~cm}$. 
MAR/168 - C. Mar. 2002 Sector 01 [0584] 6102. Fragmentos de bordo e parede. Lábio arredondado e esvasado, formando um rebordo saliente, rematado por uma canelura. A ligação do lábio à parede é feita com o recurso a uma segunda canelura, mais pronunciada. Pasta de cor laranja clara, dura, compacta e pouco depurada. Verniz negro, aderente, espesso e pouco brilhante. Diâmetro de bordo: $19 \mathrm{~cm}$.

MAR/169 - C. Mar. 1984 Corte 01 Quadrado E 02 Nível 04 2803. Fragmento de bordo e parede. Lábio arredondado e esvasado, formando um rebordo saliente. Exibe uma banda em reserva na superfície externa, imediatamente a seguir ao lábio. Pasta de cor laranja, dura, compacta e muito depurada. Verniz negro, aderente, espesso, brilhante, de boa qualidade. Diâmetro de bordo: 21, $2 \mathrm{~cm}$.

MAR/170 - C. Mar. 2000 Sector 01 [0028/0035] 0654. Três fragmentos com colagem entre si, correspondendo a bordo e parede. Lábio arredondado e esvasado, formando um rebordo saliente. Pasta de cor laranja, dura, compacta e muito depurada. Verniz negro, aderente, espesso, brilhante, de boa qualidade. Não ilustrado.

\subsubsection{As páteras das formas 21 ou 22 (Incurving Rim Bowl / Outturned Rim Bowl)}

Como já referimos anteriormente, as formas 21 e 22 de Lamboglia partilham um conjunto de características, sobretudo ao nível dos pés, dos fundos e da decoração sobre o fundo interno destes últimos que, na presença exclusiva de fragmentos daqueles, torna difícil, e mesmo impossível, em muitos casos, a adscrição a um ou a outro tipo. Assim, integrámos numa única categoria, páteras, 25 fragmentos (17 indivíduos), que podem corresponder, indistintamente, à forma 21 ou 22, dos quais 13 foram recolhidos em níveis conservados da Idade do Ferro.

Alguns destes encontram-se em estratos datados da primeira metade do século IV (U.E. [0741] - MAR/174 e MAR/190; U.E. [0593] - MAR/177; U.E. [0049] - MAR/187; U.E. [0542] - MAR/188; U.E. [0051] - MAR/189), sendo de destacar a associação, num destes casos (U.E. [0593]), a um fragmento de figuras vermelhas (MAR/007) e a ânforas do tipo Pellicer B/C, e, em outro (U.E. [0049]), a um fragmento da forma Lamboglia 21/25B (MAR/213). Desta mesma cronologia serão alguns níveis escavados durante as campanhas da década de 80 do século passado, como é o caso do nível 06 do Quadrado D 03, que proporcionaram dois fragmentos de Lamboglia 21/22 (MAR/179 e MAR/180) e um outro seguramente pertencente à forma Lamboglia 21 (MAR/158).

Esta forma surge também em níveis tardios da Idade do Ferro, posteriores ao último quartel do século IV a.n.e., considerando a sua associação a produções de Kuass. É o caso das peças MAR/171, MAR/176, MAR/186 e MAR/193 do nível o4 do Quadrado E 03, ainda que neste mesmo nível se tenham identificado outros fragmentos de cerâmica ática de verniz negro, especificamente taças Cástulo (MAR/105), skyphoi (MAR/151), pratos de peixe (MAR/197) e asas de forma indeterminada (MAR/285 e MAR/287). A mesma associação com cerâmica de tipo Kuass foi verificada no nível 03 do Quadrado E 01 (MAR/195), para o qual se propõe uma cronologia a partir do último quartel do século IV a.n.e. Não é improvável que estas cerâmicas gregas correspondam a materiais residuais nestes contextos já tão avançados.

\section{Catálogo}

MAR/171 - C. Mar. 1983 Corte 01 Quadrado E 03 Nível 04 2807. Fragmento de pé e arranque de fundo. Pé alto, ligeiramente encurvado. Superfície de apoio em reserva. Pasta de cor bege, dura, compacta e depurada. Verniz negro com manchas esverdeadas, muito deteriorado na superfície exterior do pé. Diâmetro do pé: $15 \mathrm{~cm}$.

MAR/172 - C. Mar. 1984 Corte 01 Quadrado E 04 Nível 04 2810. Fragmento de pé. Pé alto, ligeiramente encurvado. Apresenta a superfície de apoio em reserva. A face interior do pé, na 


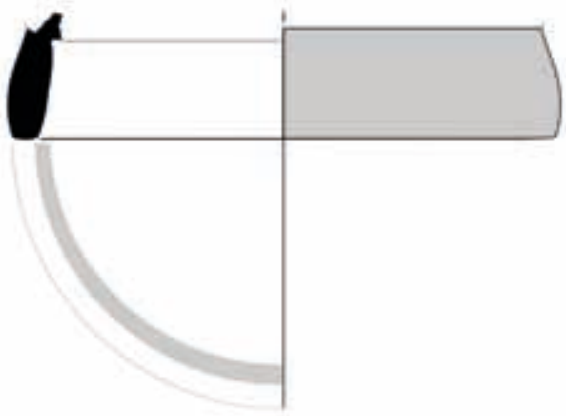

MAR/171

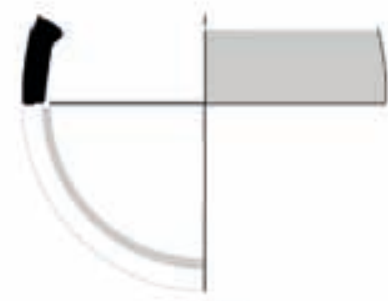

MARI173
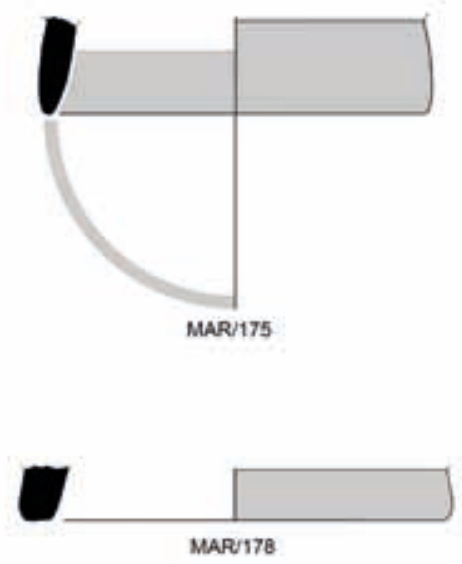

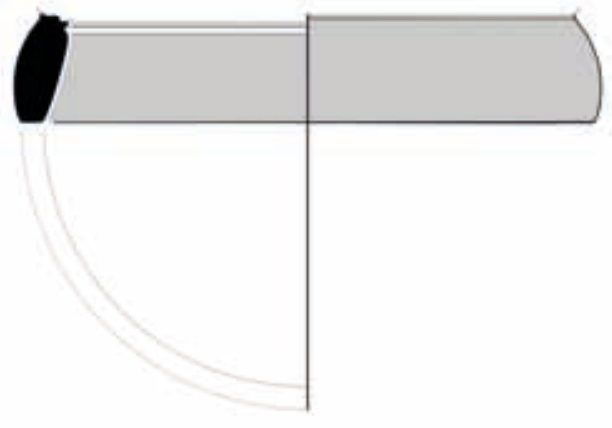

MAR/172

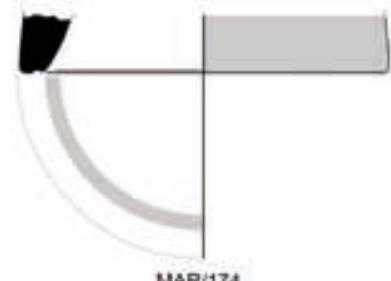

MAR/174
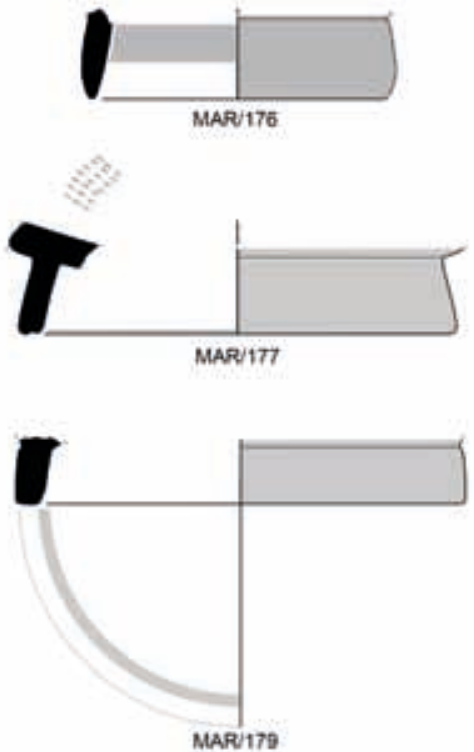

"

Fig. 34 - Páteras da forma 21/22 de Lamboglia de cerâmica ática de verniz negro do século IV a.n.e. 


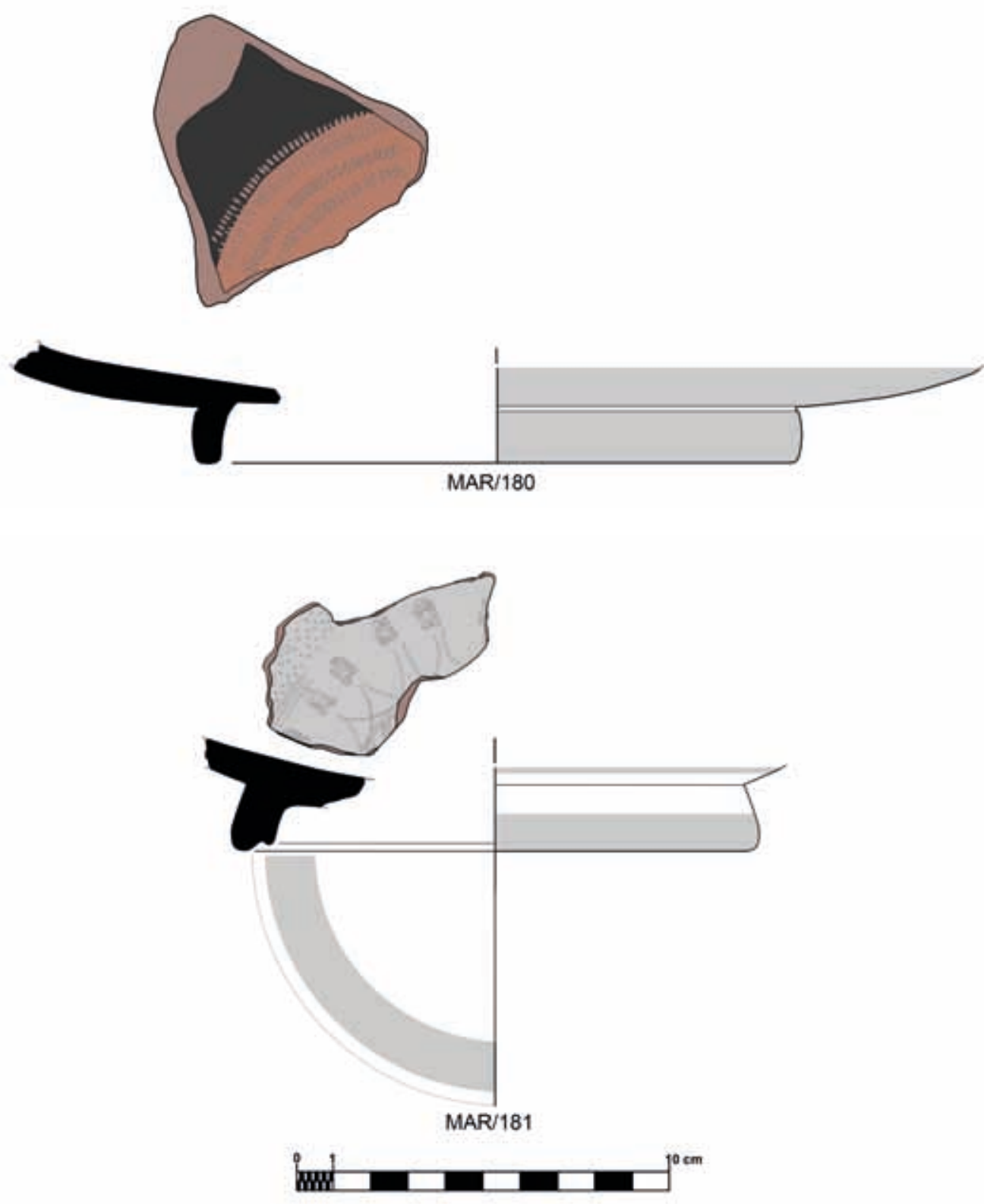

Fig. 35 - Páteras da forma 21/22 de Lamboglia de cerâmica ática de verniz negro do século IV a.n.e.

ligação ao fundo, exibe canelura em reserva. Pasta de cor bege e tonalidade alaranjada, dura, compacta e depurada. Verniz negro com manchas acinzentadas e acastanhadas, aderente, espesso e brilhante. Diâmetro do pé: $15,8 \mathrm{~cm}$.

MAR/173 - C. Mar. 1985 Corte 01 Quadrado D 03 Sem nível 2812. Fragmento de pé. Pé alto e ligeiramente encurvado. Apresenta a superfície de apoio em reserva, com canelura central. Pasta de cor laranja, dura, depurada e compacta. Verniz negro, aderente, pouco espesso e brilhante. Diâmetro do pé: $10 \mathrm{~cm}$.

MAR/174 - C. Mar. 2003 Sector 01 [0741] 11628. Fragmento de pé. Pé alto, ligeiramente encurvado. Exibe canelura em reserva na superfície de apoio do pé. Pasta de cor bege e tonalidade 


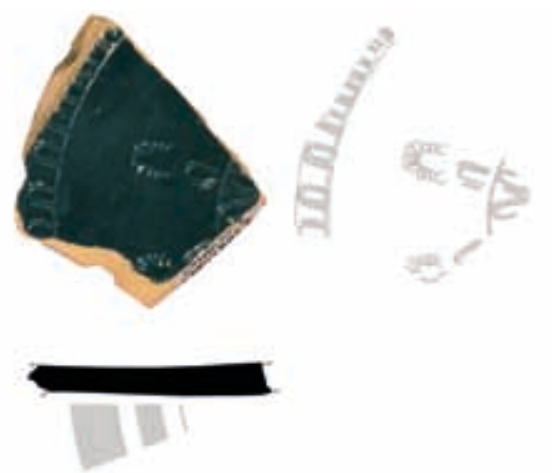

MAR/182

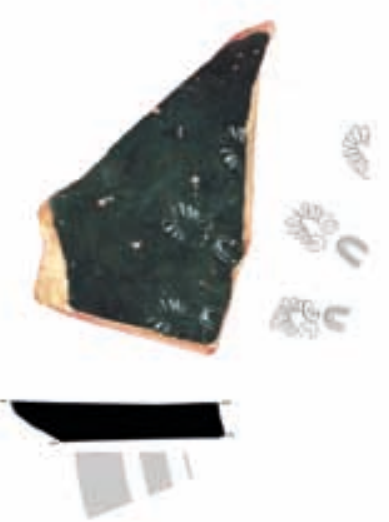

MAR/184

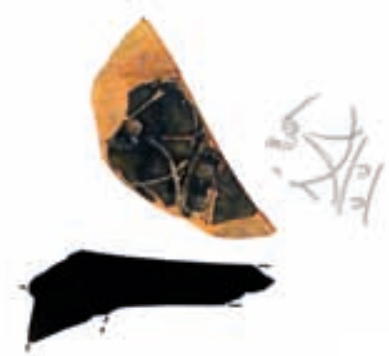

MAR/187

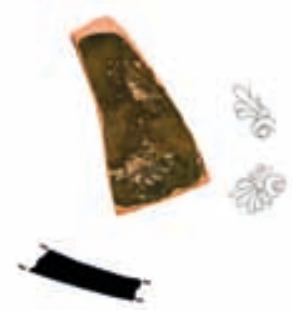

MAR/189

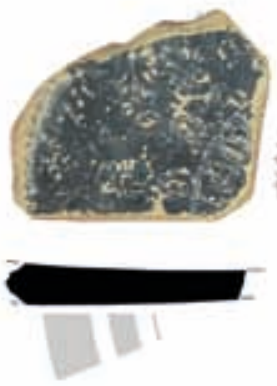

MAR/183
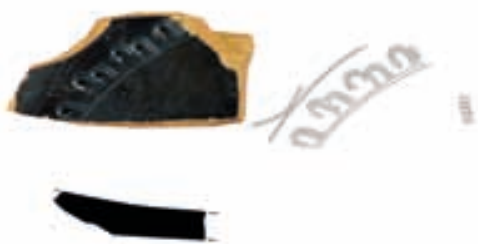

MAR/185

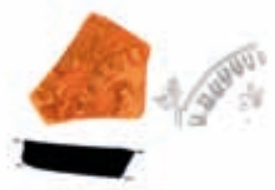

MAR/186

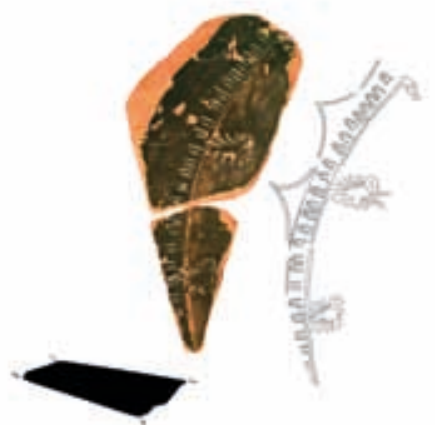

MAR/188

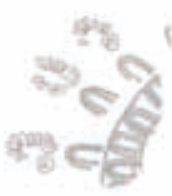



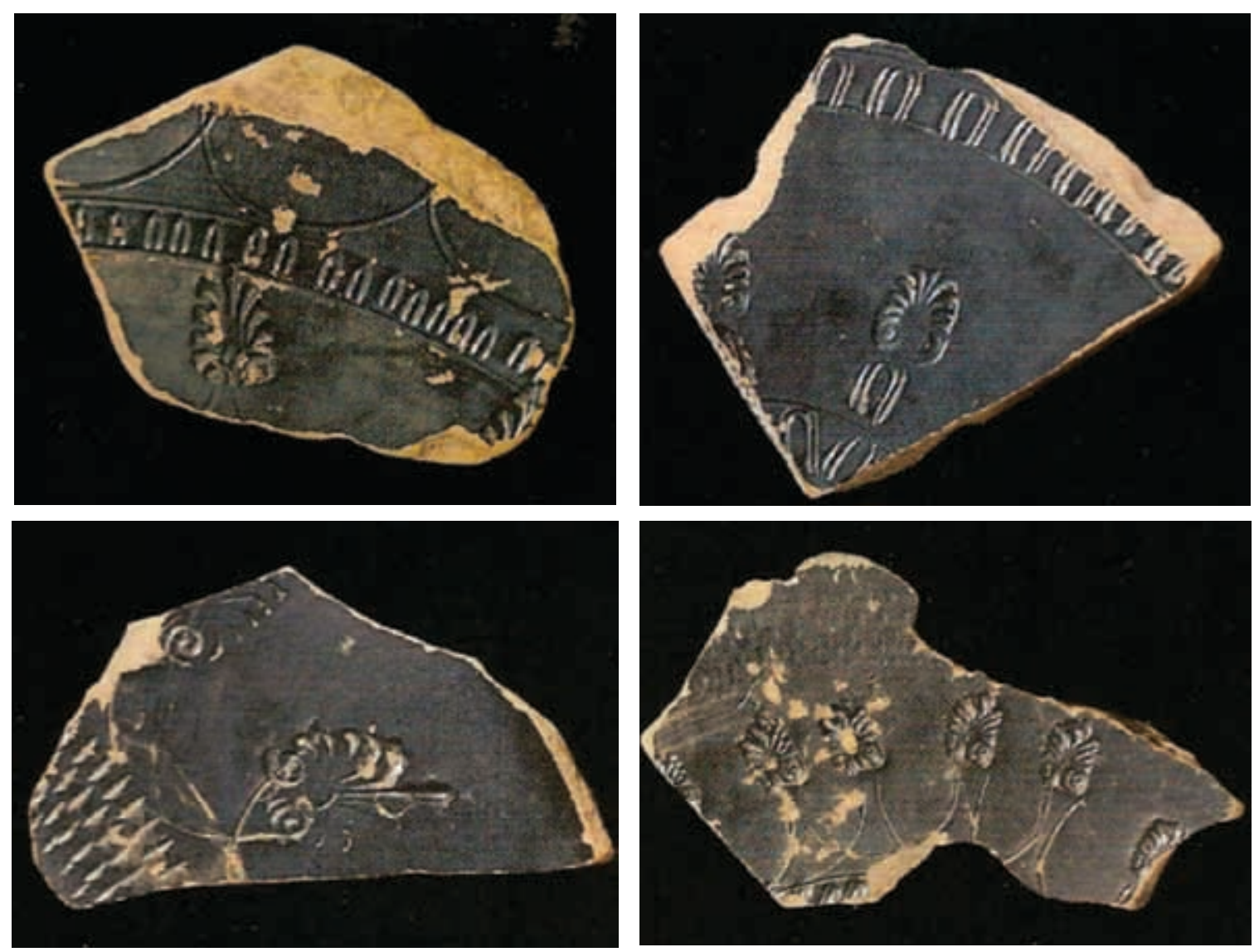

Fig. 37 - Páteras da forma 21/22 de Lamboglia de cerâmica ática de verniz negro do século IV a.n.e. (fotografia de Víctor S. Gonçalves).

alaranjada, dura, compacta e depurada. Verniz negro, aderente, espesso e de boa qualidade. Diâmetro do pé: $10 \mathrm{~cm}$.

MAR/175 - C. Mar. 1988 Corte 03 Quadrado E 05 Nível 01 2813. Fragmento de pé. Pé alto e ligeiramente encurvado. A face interna do pé exibe uma banda em verniz, seguida de uma linha de verniz de cor avermelhada e de uma banda reservada. Pasta de cor bege, dura, compacta e depurada. Verniz negro com abundantes manchas acinzentadas, aderente e pouco espesso. Diâmetro do pé: $10,6 \mathrm{~cm}$.

MAR/176 - C. Mar. 1983 Corte 01 Quadrado E 03 Nível 04 2811. Fragmento de pé. Pé alto, recto, estreitado na superfície de apoio. Apresenta banda em reserva na superfície interna do pé. Pasta de cor laranja, dura, compacta e depurada. Verniz negro, espesso, aderente e brilhante. Diâmetro do pé: $8,2 \mathrm{~cm}$.

MAR/177 - C. Mar. 2002 Sector 01 [0593] 6190. Fragmento de pé, arranque de parede e arranque de fundo. Pé alto, ligeiramente encurvado, com canelura na superfície de apoio. Apresenta-se totalmente engobado, com excepção de uma banda reservada, presente na superfície externa, na ligação do pé à parede. A superfície interior do fundo exibe decoração composta de três círculos de estrias. Pasta de cor laranja, dura, compacta e depurada. Verniz negro, aderente, espesso e muito brilhante. Diâmetro do pé: $12 \mathrm{~cm}$.

MAR/178 - C. Mar. 2000 Sector 01 [0052] 1324. Fragmento de pé. Pé alto e recto. Apresenta-se totalmente envernizado. Pasta de cor laranja, dura, compacta e depurada. Verniz negro, aderente e 


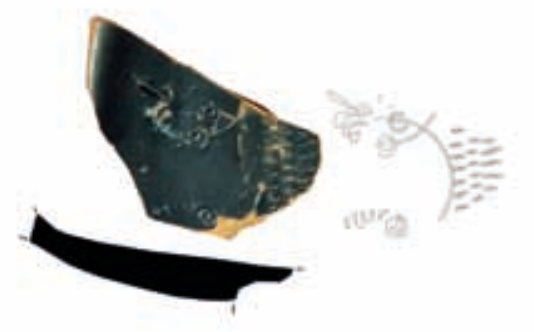

MAR/190

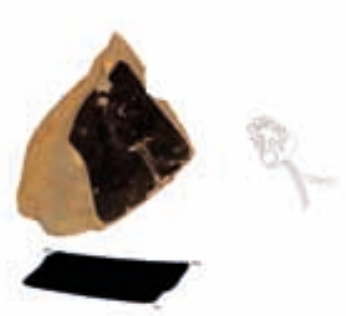

MAR/191

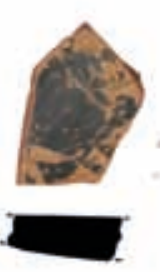

MAR/192

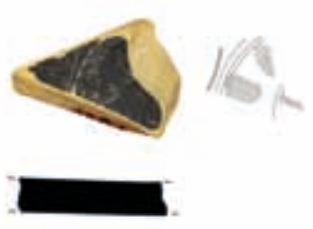

MAR/193

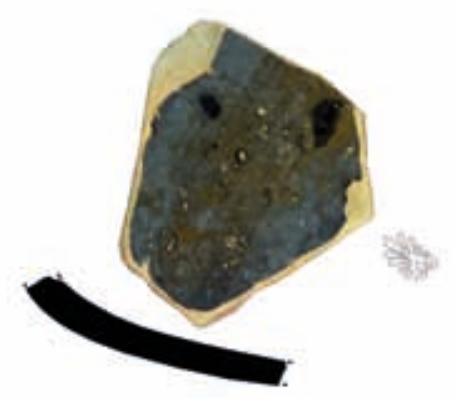

MAR/194

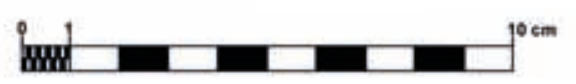

Fig. 38 - Páteras da forma 21/22 de Lamboglia de cerâmica ática de verniz negro do século IV a.n.e.

pouco espesso. O verniz apresenta-se deteriorado na superfície de apoio do pé. Diâmetro do pé: $11,6 \mathrm{~cm}$.

MAR/179 - C. Mar. 1985 Corte 01 Quadrado D 03 Nível 06 2808. Fragmento de pé. Pé alto e ligeiramente encurvado. A superfície de apoio encontra-se reservada. Pasta de cor laranja, dura, compacta e depurada. Verniz negro, aderente, espesso e brilhante. Na superfície interna do pé o verniz apresenta uma tonalidade avermelhada. Diâmetro do pé: 12,4 cm.

MAR/180 - C. Mar. 1985 Corte 01 Quadrado D 03 Nível 06 2806. Fragmento de parede, fundo e pé. Pé alto, ligeiramente encurvado. A ligação da parede ao pé é feita através de uma canelura em reserva. A superfície de apoio do pé é igualmente em reserva. A superfície interna do fundo e o fundo externo exibem verniz de cor vermelha com tonalidade alaranjada. As restantes superfícies apresentam verniz negro com manchas acinzentadas, pouco espesso e aderente. O fundo interno é decorado com vestígios de três círculos concêntricos de estrias. Diâmetro do pé: 15,8 cm.

MAR/181 - C. Mar. 2002 Sector 01 [0360] 3963. Fragmento de parede, fundo e pé. Pé alto, ligeiramente encurvado e com canelura na superfície de apoio. Apresenta a superfície de apoio e a ligação do pé à parede em reserva. A superfície interior do fundo exibe decoração composta de círculos de estrias curtas a delimitar vestígios de círculos concêntricos. Apresenta igualmente 
vestígios de seis palmetas, pequenas, de nove pétalas, com núcleo central e volutas. As palmetas encontram-se despegadas dos caulículos. Numa zona mais central exibe uma banda de óvulos, inscrita entre círculos concêntricos. Os óvulos são distribuídos em pares. A decoração regista paralelos com o taller Sec-8 do naufrágio da embarcação El Sec, reportando-se a páteras da forma 22 de Lamboglia, ainda que um padrão semelhante se verifique igualmente em páteras da forma 21. Pasta de cor bege, dura, compacta e depurada. Verniz negro, baço e pouco espesso na face externa do pé. Diâmetro do pé: 13,3 cm. Bibliografia: Arruda 2007: 145, fig. 79.

MAR/182 - C. Mar. 2002 Sector 01 [0584] 6053. Fragmento de fundo. Decorado na face interna com dois círculos de óvulos a delimitar palmetas. Palmetas despegadas, de nove pétalas, associadas a linguetas. Fundo externo em reserva, decorado com três círculos concêntricos. Pasta de cor bege e tonalidade alaranjada, dura, compacta e depurada. Verniz negro, aderente, espesso e brilhante. Bibliografia: Arruda 2007: 145, fig. 77.

MAR/183 - C. Mar. Sup. sem n. ${ }^{\circ} 16$. Fragmento de fundo. Decorado na face interna com dois círculos de óvulos a delimitar palmetas. Palmetas despegadas, associadas a linguetas. Fundo externo em reserva, decorado com três círculos concêntricos. Pasta de cor bege e tonalidade alaranjada, dura, compacta e depurada. Verniz negro, aderente, espesso e brilhante e muito deteriorado.

MAR/184 - C. Mar. 2002 Sector 01 [sup.] 0011. Fragmento de fundo. Decorado na face interna com palmetas despegadas associadas a linguetas. Fundo externo em reserva, decorado com três círculos concêntricos. Pasta de cor bege e tonalidade alaranjada, dura, compacta e depurada. Verniz negro, aderente, espesso e brilhante.

MAR/185 - C. Mar. 2002 Sector 01 [0360] 3962, 3969 e 3948. Conjunto de três fragmentos pertencentes à mesma peça, correspondendo a um fundo de pátera da forma 21/22 de Lamboglia. Decorado na superfície interna com banda de óvulos. Óvulos agrupados em pares e delimitadas por círculos concêntricos incisos. Vestígios de caulículos e pétalas de palmeta. Regista paralelos com o taller Sec-8 do naufrágio da embarcação El Sec, reportando-se a páteras da forma 21 ou 22 de Lamboglia.

MAR/186 - C. Mar. 1985 Corte 01 Quadrado E 03 Nível 04 3505. Fragmento de fundo correspondendo a pátera da forma 22 de Lamboglia. A superfície interna é decorada com banda de óvulos delimitada por círculos incisos. Exibe palmetas unidas por calículos, apresentando as mesmas núcleo central e volutas. Tal como no fragmento MAR/188, a banda de óvulos associados a círculos concêntricos é delimitada por vestígios de duas bandas de palmetas. A decoração regista paralelos com o taller Sec-5 do naufrágio da embarcação El Sec. Pasta de cor laranja, dura, compacta e depurada. Verniz cinzento com manchas avermelhadas, aderente e pouco espesso.

MAR/187 - C. Mar. 2000 Sector 01 [0049] 1163. Fragmento de fundo e arranque de pé. A superfície interna apresenta-se decorada com banda de óvulos delimitada por círculos incisos. Exibe palmetas com volutas, apresentando-se as mesmas despegadas. A decoração, ainda que residual, poderá corresponder ao taller Sec- 5 ou taller Sec-3 do naufrágio da embarcação El Sec. Pasta de cor laranja, dura, compacta e depurada. Verniz negro com manchas de tonalidade acinzentada, aderente e pouco espesso.

MAR/188 - C. Mar. 2002 Sector 01 [0542] 6050; C. Mar. 2003 Sector 01 [0641] 11701. Dois fragmentos de fundo correspondendo à mesma peça. A superfície interna é decorada com banda de óvulos delimitada por círculos concêntricos incisos. Estes elementos encontram-se, por sua vez, delimitados por vestígios de duas bandas de palmetas. As palmetas exibem nove pétalas, núcleo central e volutas, apresentando-se unidas por calículos. Pasta de cor laranja, dura, compacta e depurada. Verniz negro, aderente, espesso e brilhante. Bibliografia: Arruda 2007: 145, fig. 78. 
MAR/189 - C. Mar. 2000 Sector 01 [0051] 0961. Fragmento de fundo. A superfície interna apresenta decoração composta de palmetas com núcleo central e volutas. A decoração regista paralelos possivelmente com o taller Sec-2 ou Sec-5 do naufrágio da embarcação El Sec. Pasta de cor laranja, dura, compacta e depurada. Verniz negro com manchas acastanhadas, aderente, pouco espesso.

MAR/190 - C. Mar. 2003 Sector 01 [0741] 11627. Dois fragmentos de fundo possivelmente pertencentes à mesma peça. A superfície interna é decorada com palmetas de pétalas compridas, com volutas, e possivelmente núcleo central. As palmetas, de onze pétalas, encontram-se ligadas por caulículos. Mais próximo da zona central do fundo, conserva decoração composta de quatro bandas de estrias. Pasta de cor bege e tonalidade alaranjada, dura, compacta e depurada. Verniz negro, aderente, espesso e brilhante. Bibliografia: Arruda 2007: 145, fig. 79.

MAR/191 - C. Mar. 1985 Corte 01 Quadrado F 01 Nível 02 1575. Fragmento de fundo. A superfície interna conserva decoração composta de com palmeta com núcleo central e volutas. Exibe igualmente vestígios de caulículos associados à palmeta. Pasta de cor laranja e tonalidade acinzentada, dura, compacta e depurada. Verniz negro, aderente, espesso e baço.

MAR/192 - C. Mar. Sup. sem n. ${ }^{\circ}$ 17. Fragmento de fundo. A superfície interna é decorada com palmetas de pétalas curtas e volutas. As palmetas encontram-se ligadas por caulículos. São visíveis vestígios de uma banda de óvulos. Pasta de cor laranja, dura, compacta e depurada. Verniz negro, espesso e aderente.

MAR/193 - C. Mar. 1983 Corte 01 Quadrado E 03 Nível 04 2821. Fragmento de parede e fundo. Decorado na superfície interna com círculos concêntricos incisos a delimitar uma banda de óvulos e vestígios de possível caulículo. Pasta de cor laranja, dura, compacta e depurada. Verniz aderente, espesso e baço. Bibliografia: Arruda 1997: 137.

MAR/194 - C. Mar. Sup. 2814. Fragmento de fundo. A superfície interna exibe decoração composta de palmeta de pétalas curtas e encurvadas. Pasta de cor bege, pouco depurada e compacta. Verniz negro com abundantes manchas acastanhadas e avermelhadas, aderente e pouco espesso.

MAR/195 - C. Mar. 1984 Corte 01 Quadrado E 01 Nível 03 2820. Fragmento de fundo. Pé fracturado. $\mathrm{O}$ que resta do fundo externo, junto ao pé, em reserva. Na superfície interna, uma palmeta de pétalas despegadas e descaídas, com núcleo central, ligadas por calículos, sob os quais é visível um grupo de cinco óvulos inscritos em círculo concêntrico. Pasta dura, compacta, depurada de cor laranja claro. Verniz negro, aderente, espesso e baço. Não ilustrado.

\subsubsection{Os pratos de peixe (Fish Plate / forma 23 de Lamboglia)}

Os pratos de peixe (forma 23 de Lamboglia) são igualmente presença frequente no Castelo de Castro Marim, tendo sido identificados 14 fragmentos - 14 indivíduos. Destaca-se a grande diversidade de soluções tipológicas adoptadas, registando-se cinco exemplares de lábio pendente e seis de lábio engrossado. As duas variantes mencionadas apresentam-se, integralmente, revestidas de verniz negro, encontrando ambas paralelo nos pratos de peixe identificados no naufrágio da embarcação El Sec, datados da primeira metade do século IV a.n.e. Na Ágora de Atenas, a forma encontra os seus exemplares mais antigos datados de 397 a.n.e. (Sparkes - Talcott 1970: 147-148). Os pratos de peixe foram, a partir pelo menos do último quartel do século IV a.n.e., abundantemente reproduzidos em centros produtores ocidentais, como Kuass (Ponsich 1969), Ibiza (Amo de la Hera 1971) e Cádis (Niveau 2003), tendo a forma sido ainda fabricada em Campaniense A. 


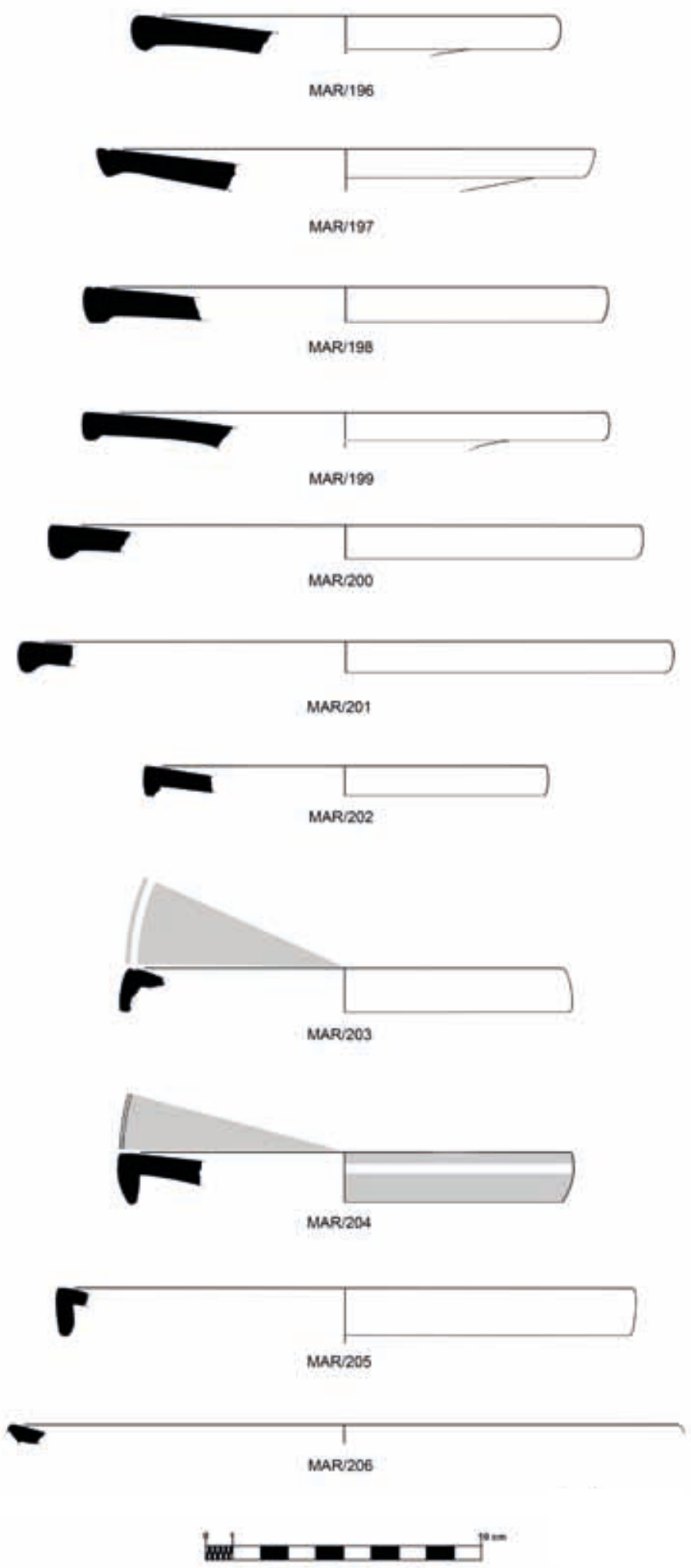

Fig. 39 - Pratos de peixe da forma 23 de Lamboglia de cerâmica ática de verniz negro do século IV a.n.e. 
No Ocidente peninsular, os pratos de peixe áticos de verniz negro são abundantes em vários sítios andaluzes, como Cádis, Castillo de Doña Blanca (Puerto de Santa Maria) e Huelva (Rouillard 1991). No território actualmente português, a forma está mal representada, mas existe em Mértola (Arruda - Barros - Lopes 1998, Barros 2010).

Dos 14 fragmentos da forma 23 de Lamboglia recolhidos em Castro Marim, oito são provenientes de níveis conservados da Idade do Ferro.

Alguns foram exumados em níveis da primeira metade do século IV a.n.e. (U.E. [0068] MAR/199; U.E. [0650] - MAR/206; U.E. [0375] - MAR/209). Deve destacar-se a associação, na U.E. [0650], do prato de peixe (MAR/206) a um fragmento de cerâmica ática de figuras vermelhas (MAR/019) e a uma ânfora do tipo Pellicer B/C.

Desta mesma cronologia será o nível 03 do Quadrado C 04, no qual o prato de peixe (MAR/202) está associado a ânforas do tipo Pellicer $\mathrm{B} / \mathrm{C}$ e a outros fragmentos da forma 22 de Lamboglia (MAR/161 e MAR/163), a taças Cástulo (MAR/095 e MAR/096), a taça da Classe Delicada (MAR/116) e a fragmentos de forma indeterminada (MAR/247 e MAR/272).

Tal como em outros casos, alguns dos fragmentos desta forma surgem em níveis mais tardios, com cronologias posteriores aos finais do século IV a.n.e., podendo considerar-se residuais. É o caso das peças MAR/196 e MAR/198, provenientes do nível 04 do Quadrado D3, onde estão associadas a produções de tipo Kuass, e a ânforas, dos tipos Pellicer B/C e D, Tiñosa (8.1.1.2 de Ramon Torres) e Maña Pascual A4 (séries 11 e 12 de Ramon Torres). Neste nível, também estão presentes outras formas de cerâmica ática de verniz negro, concretamente da forma Jehasse 116 (MAR/211) e indeterminada (MAR/274), e também de figuras vermelhas (MAR/014). A peça MAR/197, recolhida no nível 04 do Quadrado E 03, tem as mesmas associações contextuais que estabelecem uma cronologia a partir do terceiro quartel do século IV, ainda que, neste caso, a cerâmica grega associada corresponda às formas Lamboglia 21/22 (MAR/171, MAR/176, MAR/186 e MAR/193), taças Cástulo (MAR/105), skyphoi (MAR/151) e asas de forma indeterminada (MAR/285 e MAR/287).

A peça MAR/208 surge, uma vez mais, num nível com cronologia posterior ao terceiro quartel do século IV a.C., em associação a cerâmica de tipo Kuass, ânforas de tipo Tiñosa (8.1.1.2 de Ramon Torres) e Pellicer D.

\section{Catálogo}

MAR/196 - C. Mar. 1985 Corte 01 Quadrado D 03 Nível 04 2818. Fragmento de bordo e parede. Bordo de lábio espessado. O avançado estado de deterioração do verniz não permite identificar áreas em reserva. Pasta de cor laranja, dura, compacta e depurada. São visíveis minúsculas partículas de mica. Verniz negro, aderente, espesso e baço. Diâmetro de bordo: 15,2 cm.

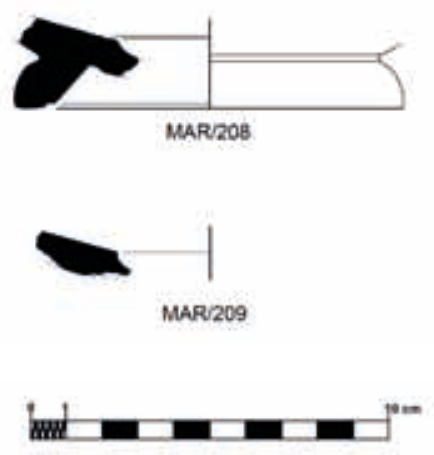

Fig. 40 - Pratos de peixe da forma 23 de Lamboglia de cerâmica ática de verniz negro do século IV a.n.e. 
MAR/197 - C. Mar. 1984 Corte 01 Quadrado E 03 Nível 04 2816. Fragmento de bordo e parede. Bordo de lábio espessado. A ligação da parede ao lábio é feita, na superfície interna, através de uma canelura. Apresenta-se totalmente envernizado. Pasta de cor laranja claro, dura, compacta e pouco depurada. Verniz castanho com manchas negras, aderente, pouco espesso e baço. Diâmetro de bordo: $18 \mathrm{~cm}$.

MAR/198 - C. Mar. 1985 Corte 01 Quadrado D 03 Nível 04 2817. Fragmento de bordo e parede. Bordo de lábio espessado. A ligação da parede ao lábio é feita, na superfície interna, através de uma canelura. O avançado estado de deterioração do verniz não permite identificar áreas em reserva. Pasta de cor bege e tonalidade alaranjada, dura, compacta e pouco depurada. Verniz negro, aderente, espesso e brilhante. Diâmetro de bordo: $19 \mathrm{~cm}$.

MAR/199 - C. Mar. 2001 Sector 01 [0068] 1825. Fragmento de bordo e parede. Bordo de lábio espessado. $O$ avançado estado de deterioração do verniz não permite identificar áreas em reserva. Pasta de cor laranja, dura, compacta e depurada. São visíveis minúsculas partículas de mica. Verniz negro, aderente, espesso e brilhante. Diâmetro de bordo: $19 \mathrm{~cm}$.

MAR/200 - C. Mar. 2002 Sector 01 [0385] 5329. Fragmento de bordo e parede. Bordo de lábio espessado. O avançado estado de deterioração do verniz não permite identificar áreas em reserva. Pasta de cor laranja, dura, compacta e depurada. São visíveis minúsculas partículas de mica. Verniz negro, aderente, espesso e brilhante. Diâmetro de bordo: $21,4 \mathrm{~cm}$.

MAR/201 - C. Mar. Sup. 3079. Fragmento de bordo e parede. Bordo de lábio espessado. O avançado estado de deterioração do verniz não permite identificar áreas em reserva. Pasta de cor laranja, dura, compacta e depurada. Verniz negro, aderente, espesso e brilhante. Diâmetro de bordo: $23,55 \mathrm{~cm}$.

MAR/202 - C. Mar. 1987 Corte 03 Quadrado C 04 Nível 03 2819. Fragmento de bordo e parede. Bordo de lábio pendente, fragmentado na extremidade. O avançado estado de deterioração do verniz não permite identificar áreas em reserva. Pasta de cor laranja, dura, compacta e depurada. Verniz negro, muito deteriorado. Diâmetro de bordo: $14,6 \mathrm{~cm}$.

MAR/203 - C. Mar. 2000 Sector 01 [0014] 1337. Fragmento de bordo e arranque de parede. Bordo de lábio pendente. A ligação da parede ao lábio é feita, na superfície interior, através de uma canelura em reserva. Pasta de cor laranja, dura, compacta e pouco depurada. Verniz negro, aderente, pouco espesso e brilhante. Diâmetro de bordo: $15,9 \mathrm{~cm}$.

MAR/204 - C. Mar. 2002 Sector 01 [0360] 3961. Fragmento de bordo e parede. Bordo de lábio pendente. A superfície externa da aba apresenta banda reservada. A ligação da parede à aba é, na superfície interna, igualmente reservada. Diâmetro de bordo: 16,4 cm.

MAR/205 - C. Mar. Sup. 2722. Fragmento de bordo e parede. Bordo de lábio pendente. O avançado estado de deterioração do verniz não permite confirmar a presença de áreas em reserva. Pasta de cor laranja, dura, compacta e depurada. Verniz negro, aderente, espesso e brilhante. Diâmetro de bordo: $21 \mathrm{~cm}$.

MAR/206 - C. Mar. 2003 Sector 01 [0650] 10133. Fragmento de bordo e arranque de parede. Bordo de lábio pendente, fragmentado na extremidade. Pasta de cor laranja, dura, compacta e depurada. Verniz negro, aderente, espesso e brilhante. Diâmetro de bordo: $24,3 \mathrm{~cm}$.

MAR/207 - C. Mar. 1987 Corte 03 Quadrado D 04 Nível 01 2843. Fragmento de aba. O verniz apresenta-se muito deteriorado, impossibilitando a confirmação de áreas em reserva. Pasta de cor laranja, dura, compacta e depurada. Não ilustrado. 
MAR/208 - C. Mar. 1984 Corte 01 Quadrado E 02 Nível 05 4603. Fragmento de parede, fundo e pé. Pé alto, encurvado. A ligação do pé à parede é feita, na superfície externa, através de uma pequena garganta e, na superfície interna, através de uma canelura. A superfície de apoio do pé apresenta igualmente uma canelura. Conserva parte do reservatório. Pasta de cor laranja, dura, compacta e depurada. Verniz negro com manchas acastanhadas e avermelhadas. Muito deteriorado, impossibilitando a confirmação das áreas em reserva. Diâmetro do pé: 10,7cm.

MAR/209 - C. Mar. 2002 Sector 01 [0375] 6047. Fragmento de parede com arranque do reservatório. A superfície exterior do fundo apresenta-se fraturada. Pasta de cor laranja, dura, compacta e pouco depurada. São visíveis minúsculas partículas de mica. Verniz negro, aderente, espesso, brilhante, muito deteriorado.

\subsubsection{Os pratos Jehasse 116 (Rolled Rim)}

Isolados ou em associação estratigráfica aos pratos de peixe, regista-se a presença de dois exemplares (dois indivíduos) de pratos da forma Jehasse 116. Trata-se de fragmentos de fundo e pé, decorados na superfície interna do fundo com círculos de estrias semelhantes a peças atribuídas ao taller Sec-11, presente no naufrágio de El Sec (Arribas et al. 1987). Os pés são baixos, de perfil arredondado, simples, e com a face externa convexa. Este tipo de prato começou a fabricar-se do primeiro quartel do século IV a.n.e., tendo perdurado até à época helenística (Sparkes - Talcott 1970: 144-147).

A forma é relativamente rara fora da Grécia, havendo, naturalmente, que referir aqui os oriundos da necrópole de Aléria (Jehasse - Jehasse 1973). Sabemos, porém, que estes pratos foram distribuídos no ocidente, dada a sua presença no naufrágio de El Sec (Arribas et al. 1987). Apesar da sua escassa representação na Península Ibérica, com ocorrências pontuais e numericamente insignificativas em algumas necrópoles da região murciana (García Cano 1997), em Portugal foram identificados em contextos habitacionais também no Castelo de Moura (Soares 2017) e ainda na necrópole de Alcácer do Sal (Rouillard et al. 1988-1989).

Em Castro Marim, apenas um dos dois fragmentos da forma Jehasse 116 foi recolhido num nível conservado da Idade do Ferro. Trata-se da peça $M A R / 211$, exumada no quadrado D 03, nível
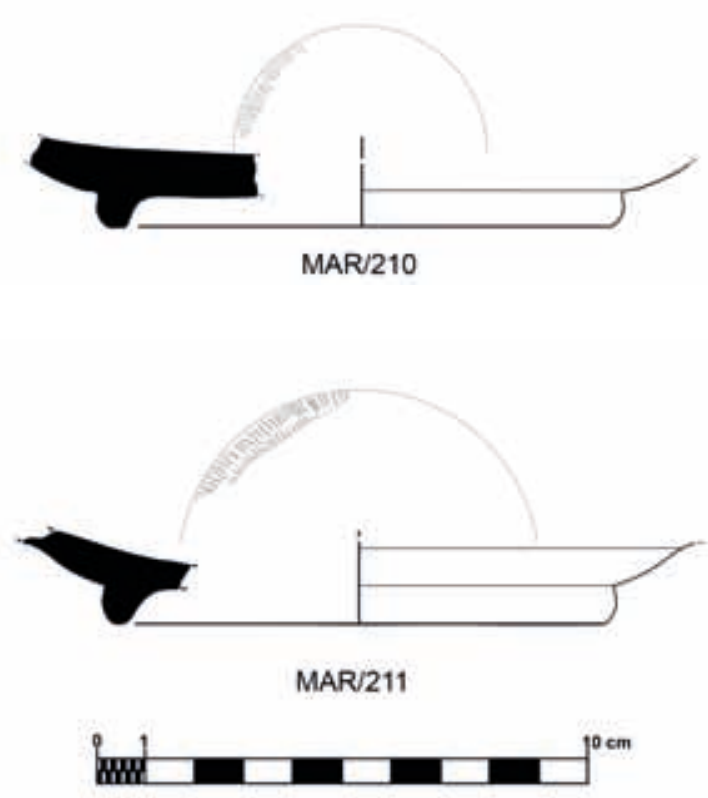

Fig. 41 - Pratos da forma Jehasse 116 de cerâmica ática de verniz negro do século IV a.n.e. 
04, em associação a outras formas de cerâmica ática de verniz negro (pratos de peixe - MAR/196 e MAR/198; cerâmica ática de figuras vermelhas - MAR/014; forma indeterminada de verniz negro - MAR/274), ânforas de tipo B/C, D de Pellicer, Maña Pascual A4 (séries 11 e 12 de Ramon Torres) e produções de tipo Kuass. Este conjunto de materiais deixa antever o carácter residual dos fragmentos áticos, ou intrusivo das cerâmicas de Kuass e das ânforas D de Pellicer e Mañá Pascual A4 (série 12 de Ramón Torres). Outra possibilidade a considerar, que já foi avançada nas páginas anteriores para situações semelhantes, será a do período de amortização dos recipientes gregos poder ser mais prolongado.

\section{Catálogo}

MAR/210 - C. Mar. 2002 Sector 01 [0109] 1945. Fragmento de parede, fundo e pé. Apresentase totalmente envernizado. O fundo interno apresenta decoração composta de vestígios de um círculo concêntricos de estrias. Pasta de cor laranja, dura, compacta e depurada. Verniz negro, com manchas avermelhadas, aderente, pouco espesso e brilhante. Diâmetro do pé: 10,2 cm.

MAR/211 - C. Mar. 1986 Corte 01 Quadrado D 03 Nível 04 2815. Fragmento de parede, fundo e pé. Apresenta-se totalmente envernizado. O fundo interno apresenta decoração composta de vestígios de dois círculos concêntricos de estrias, apresentando-se as estrias em forma de «s». Regista paralelo com a decoração característica do taller Sec-11 do naufrágio de El Sec. Pasta de cor laranja, dura, compacta e depurada. Verniz negro, muito aderente, espesso e brilhante. Diâmetro do pé: $10,4 \mathrm{~cm}$.

\subsubsection{O saltcellar}

Um fundo plano, muito espesso e de pequeno diâmetro (inferior a $5 \mathrm{~cm}$ ) pode ter feito parte do que, na Ágora de Atenas, foi incluído no grupo dos saltcellars, mas o seu avançado estado de deterioração e fragmentação, que não permite determinar de forma exata os atributos deste exemplar, obriga a alguma cautela nesta inclusão. Regista o seu paralelo mais próximo nos exemplares n. 919 e 923 da Ágora de Atenas (Sparkes - Talcott 1970: 70, pls. 11, 47, fig. 3), datados do final do século $V$ a.n.e. Os "saleiros" são conhecidos na Península Ibérica, mas na sua versão hemisférica de paredes muito arqueadas e com pé (Forma 24 de Lamboglia) já do século IV a.n.e., desconhecendo-se, até ao momento exemplares idênticos ao que é aqui apresentado.

O possível fragmento de saltcellar de Castro Marim (MAR/212) foi recolhido durante o desmonte da estrutura [0581/0625], estando associado a um fragmento de asa (MAR/298) e a um

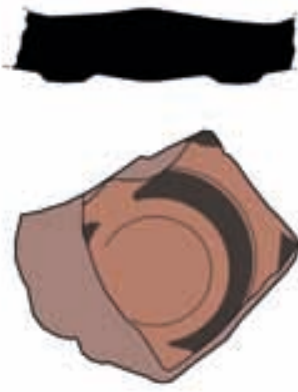

MAR/212

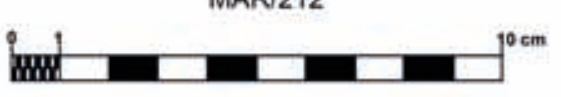

Fig. 42 - Saltcellar de cerâmica ática de verniz negro do século IV a.n.e. 
bordo de uma ânfora de tipo Maña Pascual A4 (série 12 de Ramon Torres). Considerando os dados disponíveis, é provável que a construção desta estrutura tenha ocorrido na primeira metade do século IV a.n.e., cronologia que, como vimos, contradiz a do próprio fragmento em si, realidade que se pode relacionar com a própria classificação que aqui se avança ou com questões que se prendem com a amortização de certos vasos gregos em sítios tão periféricos.

\section{Catálogo}

MAR/212 - C. Mar. 2003 Sector 01 [0581/0625] 10132. Fragmento de fundo, muito deteriorado, sendo possível verificar, em ambas as extremidades o início do arranque da parede. A superfície exterior do fundo apresenta-se reservada, decorada com círculos concêntricos em verniz negro. A superfície interior encontra-se totalmente envernizada. Pasta de cor laranja, dura, compacta e pouco depurada. Verniz muito desgastado. Diâmetro de fundo: $5 \mathrm{~cm}$.

\subsubsection{As pequenas taças da forma 21/25B}

Nino Lamboglia integrou as pequenas taças de bordo reentrante de fabrico ático na forma 21/25B, que corresponde aos small bowls with broad bases da Ágora de Atenas (Sparkes - Talcott 1971: 135). É uma forma típica do século IV a.n.e., sendo frequente na Península Ibérica, concretamente na Andaluzia, mas também no Sudeste, no Levante e na Catalunha (Trías 1967-1968, Rouillard 1991). Para Portugal, devem citar-se os exemplares de Tavira e de Faro (Barros 2005: 941, Fig. 10, $\mathrm{n}^{\circ} 1 ; 936$, Fig. 5, $\mathrm{n}^{\circ} 1$ ).

Os contextos de recolha das cinco peças (cinco indivíduos) de Castro Marim compaginam-se com estes dados, apesar de três delas serem provenientes de níveis revolvidos. As outras duas foram recolhidas em estratos conservados da Idade do Ferro. O primeiro (MAR/213) foi recuperado na U.E. [0049], de derrube/entulhamento, em associação a um fragmento da forma Lamboglia 21/22 (MAR/187), o que permitiu atribuir uma cronologia de formação desta camada em torno à primeira metade do século IV a.n.e. O restante (MAR/216) provém da U.E. [0616], já referida anteriormente pela sua associação a um fragmento de uma stemless cup (MAR/129) assumindo-se, também para este caso, uma cronologia idêntica à anterior.

\section{Catálogo}

MAR/213 - C. Mar. 2000 Sector 01 [0049] 1164. Três fragmentos com colagem entre si, correspondendo a bordo, parede e arranque de fundo. Não obstante o avançado estado de deterioração, aparenta estar totalmente envernizado. Pasta de cor laranja, dura, compacta e depurada. Verniz negro com manchas acinzentadas, aderente, espesso e brilhante. Diâmetro de bordo: 9,2 cm.

MAR/214 - C. Mar. 2002 Sector 01 [0360] 3956. Fragmento de bordo e parede. Bordo de lábio reentrante. Apresenta-se totalmente envernizado. Pasta de cor laranja, dura, compacta, depurada. Verniz negro, aderente e espesso. Diâmetro de bordo: 8,1 cm.

MAR/215 - C. Mar. 2002 Sector 01 [0526] 6087. Fragmento de bordo e parede. Bordo de lábio reentrante. A face exterior encontra-se apenas parcialmente envernizada. Pasta de cor laranja, dura, compacta e depurada. Verniz negro com abundantes manchas acinzentadas, aderente, espesso e brilhante, sendo o brilho ligeiramente metalizado. Diâmetro de bordo: $10 \mathrm{~cm}$.

MAR/216 - C. Mar. 2002 Sector 01 [0616] 6253. Fragmento de bordo e parede. Bordo de lábio reentrante. Apresenta-se totalmente envernizado. Pasta de cor laranja, dura, compacta e pouco depurada. Verniz negro com manchas acastanhadas e acinzentadas, aderente e espesso. Diâmetro de bordo: $7,6 \mathrm{~cm}$. 
MAR/217 - C. Mar. 2002 Sector 01 [0526] 6044. Fragmento de bordo e parede. Bordo de lábio reentrante. Apresenta-se totalmente envernizado. Pasta de cor bege e tonalidade alaranjada, dura, compacta e depurada. Verniz negro, aderente, espesso e brilhante. Diâmetro de bordo: $10,8 \mathrm{~cm}$.

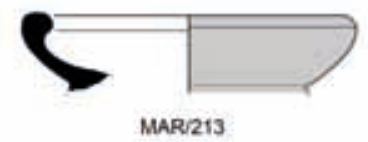

MAR/213

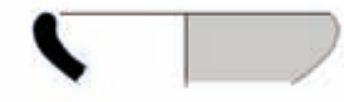

MAR214
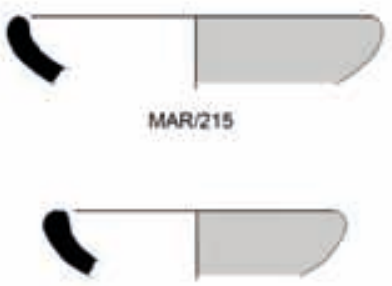

MAR/216
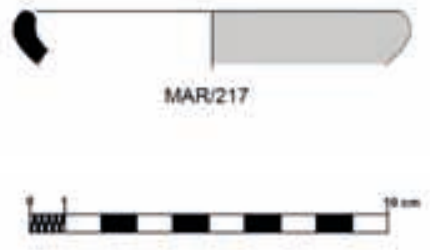

Fig. 43 - Taças da forma 21/25B de Lamboglia de cerâmica ática de verniz negro do século IV a.n.e.

\subsubsection{A lekanis}

A tampa da lekanis do Castelo de Castro Marim foi encontrada à superfície, não tendo, assim e infelizmente, qualquer contexto concreto.

Este tipo de vaso, usado para guardar jóias ou cosméticos, é muito raro no território actualmente português, tendo-se documentado apenas na Azougada (Soares 2017) e em Lisboa, onde há dois exemplares oriundos de sítios distintos da cidade. Um, correspondente à taça, é de figuras vermelhas e foi recolhido na Rua Augusta; o outro, uma tampa de verniz negro, provém da área do Castelo de São Jorge (Arruda - Sousa 2018).

$\mathrm{Na}$ própria Península Ibérica, as lekanides, cuja versão decorada com figuras vermelhas é sempre dominante, não abundam, estando presentes, a partir de finais do século $V$ a.n.e., sobretudo em Ampúrias e na sua área de influência directa, mas também na região alicantina (Rouillard 1991). Para ocidente, o panorama é ainda muito mais pobre, havendo a registar um exemplar em Cancho Roano (Gracia Alonso 2003), para além dos dois já citados de Lisboa e da Azougada. 


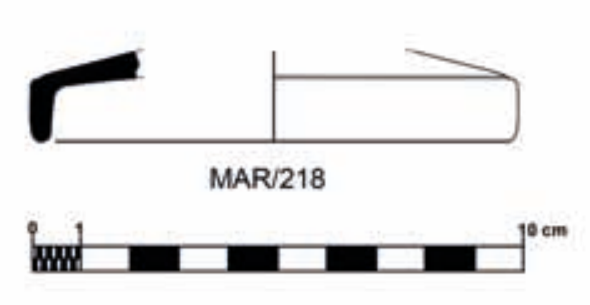

Fig. 44 - Lekanis de cerâmica ática de verniz negro do século V/IV a.n.e.

\section{Catálogo}

MAR/218 - C. Mar. Sup. sem n. ${ }^{\circ}$ 18. Fragmento de bordo. A ligação do bordo à parede é feita, na superfície exterior, através de uma canelura. A extremidade do bordo parece apresentar-se em reserva, ainda que o avançado estado de deterioração do verniz não o permita confirmar. Pasta de cor laranja, dura, compacta e pouco depurada. Verniz negro, aderente, pouco espesso e muito brilhante. Diâmetro de bordo: $10 \mathrm{~cm}$.

\subsubsection{A lucerna}

Um fragmento de bico e reservatório de uma lucerna de verniz negro foi encontrada, infelizmente em contexto pouco fiável, nas escavações do Castelo de Castro Marim. A forma é relativamente rara na Península Ibérica, ainda que esteja testemunhada, por exemplo, no naufrágio de El Sec (Arribas et al. 1987) e, com localização mais próxima, em Mértola (Arruda - Barros - Lopes 1998). Uma vez mais, a escassa dimensão e deterioração da peça castromarinense não permitiram a sua reconstituição gráfica e assim uma integração tipológica mais concreta para este artefacto cerâmico de iluminação.

\section{Catálogo}

MAR/219 - C. Mar. 1988 Corte 03 Quadrado E 06 Nível 01 2842. Fragmento do bico e reservatório. O fragmento apresenta-se totalmente revestido de verniz negro, ainda que muito deteriorado na superfície interna. Pasta de cor laranja, dura, compacta e depurada. Verniz negro, com manchas de tonalidade acastanhada, espesso, aderente e pouco brilhante. Altura conservada: $0,28 \mathrm{~cm}$. Bibliografia: Arruda 1997: 136.

\subsubsection{Os fragmentos decorados de forma indeterminada}

No Castelo de Castro Marim, foi possível identificar nove fragmentos de cerâmica ática de verniz negro, correspondendo a fundos e paredes, decorados, com decoração estampilhada na superfície interna. Não foi possível identificar os tipos exactos dos vasos a que pertenceram, sendo seguro que se trataria de formas abertas.

\section{Catálogo}

MAR/220 - C. Mar. Sup. 2822. Fragmento de fundo. Decorado com vestígios de três palmetas presentes na superfície externa. Palmetas com volutas, de pétalas curtas. Pasta de cor laranja, dura, compacta e depurada. Verniz negro com manchas acinzentadas/esverdeadas, aderente, espesso e baço. Possível correspondência com o taller Sec-3 da embarcação El Sec. Bibliografia: Arruda 1997: 138. 
MAR/221 - C. Mar. Sup. 2823. Fragmento de parede. Decorado com três linhas de estrias e palmetas unidas caulículos. Palmetas estreitas, de pétalas curtas, despegadas, com volutas e sem núcleo central. Pasta de cor laranja, dura, compacta e depurada. Verniz negro, aderente, espesso e muito brilhante. Bibliografia: Arruda 1997: 138.

MAR/222 - C. Mar. 1984 Corte 01 Quadrado E 04 Nível 03 4601. Fragmento de fundo. Decorado com banda de óvulos delimitada por círculo inciso. Vestígios de caulículos. Pasta de cor laranja, dura, compacta e muito depurada. Verniz vermelho, muito deteriorado, pouco aderente e espesso.

MAR/223 - C. Mar. 2002 Sector 01 [0373] 4186. Fragmento de fundo. A superfície interna é decorada com banda de óvulos delimitada por círculos incisos. Palmetas de pétalas longas. Pasta de cor laranja, dura, compacta e depurada. Verniz negro, aderente pouco espesso na superfície exterior e brilhante.

MAR/224 - C. Mar. Sup. 3185. Fragmento de parede, próximo do fundo. A superfície interna é decorada por círculo inciso e vestígios de pétalas de uma palmeta. Pasta de cor bege, dura, compacta e depurada. Verniz aderente, espesso e brilhante.

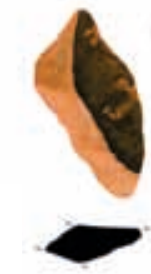

MAR/220

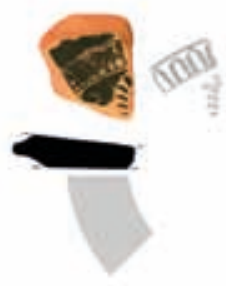

MAR/223

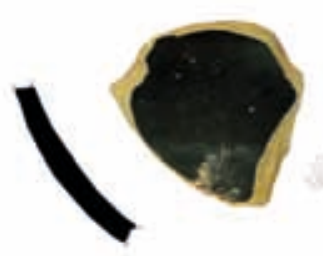

MAR/226

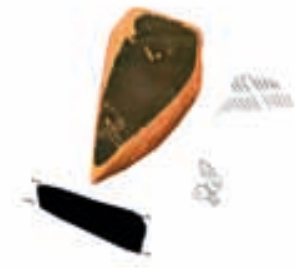

MAR/221
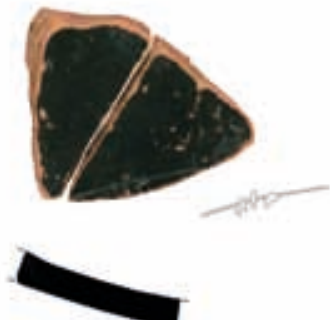

MAR/224

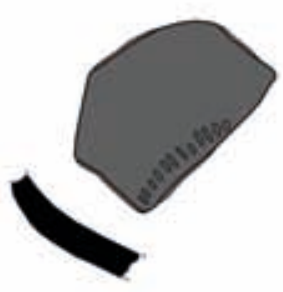

MAR/227

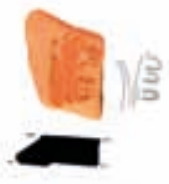

MAR/222

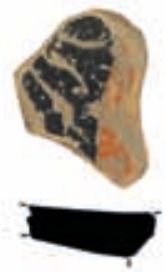

MAR/225

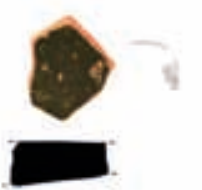

MAR/228

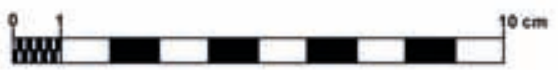

Fig. 45 - Fragmentos de forma indeterminada de cerâmica ática de verniz negro do século V/IV a.n.e. 
MAR/225 - C. Mar. Sup. sem n. ${ }^{\circ}$ 19. Fragmento de parede. A superfície interna encontra-se decorada com banda de óvulos, delimitadas por círculos concêntricos incisos. Pasta de cor laranja, dura, compacta e depurada. Verniz negro, aderente, espesso e brilhante.

MAR/226 - C. Mar. Sup. 2824. Fragmento de parede. É decorado na superfície interna com palmeta. Pasta de cor bege, dura, compacta e depurada. Verniz aderente, espesso e brilhante.

MAR/227 - C. Mar. Sup. 2825. Fragmento de parede. A superfície interna encontra-se decorada com estrias alongadas. Pasta de cor laranja, dura, compacta e depurada. Verniz negro, aderente, espesso e brilhante.

MAR/228 - C. Mar. 2002 Sector 01 [0392] 5421. Fragmento de parede. Decorado na superfície interna com vestígio de círculo e palmeta com volutas. Pasta de cor laranja, compacta e depurada. Verniz negro, aderente, espesso e brilhante. Não ilustrado.

\subsubsection{Fragmentos de parede de forma indeterminada}

Quarenta e nove fragmentos de parede cobertos de verniz negro em ambas as superfícies não foram passíveis de classificação tipológica, uma vez que se tornou impossível perceber a que tipo de vaso ático tinham pertencido. Muitos deles foram utilizados para definir parâmetros cronológicos dos contextos específicos em que foram recolhidos, e assim mereceram descrição, apesar de, como é evidente, não terem sido alvo de representação gráfica.

\section{Catálogo}

MAR/229 - C. Mar. 2002 Sector 01 [0538] 5420. Fragmento de parede de taça. Pasta de cor laranja, dura, compacta e depurada. Verniz negro, aderente, espesso e brilhante, de boa qualidade. Não ilustrado.

MAR/230 - C. Mar. 2003 Sector 01 [0064] 10126. Fragmento de parede de possível taça. Pasta de cor bege, dura, compacta e depurada. Verniz negro, aderente, espesso e brilhante. Não ilustrado.

MAR/231 - C. Mar. Sup. 5383. Fragmento de parede de possível taça. Apresenta uma curvatura pouco pronunciada, podendo corresponder à forma skyphoi. Pasta de cor bege e tonalidade alaranjada, dura, compacta e depurada. Verniz negro com manchas esverdeadas na superfície interior e avermelhadas na superfície exterior. Verniz aderente e pouco espesso. Não ilustrado.

MAR/232 - C. Mar. 2002 Sector 01 [0389] 5841. Fragmento de parede e arranque de fundo correspondendo a uma taça. Pasta de cor bege e tonalidade alaranjada, dura, compacta e depurada. A superfície interna apresenta verniz negro, aderente, espesso e brilhante. A superfície externa exibe verniz vermelho com manchas negras, pouco aderente e pouco espesso. Não ilustrado.

MAR/233 - C. Mar. 2003 Sector 01 [0707] 13490. Fragmento de parede de possível taça. Pasta de cor bege e tonalidade acinzentada, dura, compacta e depurada. Verniz negro, aderente, espesso e brilhante. Não ilustrado.

MAR/234 - C. Mar. Sup. sem n. ${ }^{\circ} 20$. Fragmento de parede de possível taça. Pasta de cor laranja, dura, compacta e depurada. Verniz negro, aderente e espesso. Não ilustrado.

MAR/235 - C. Mar. 2003 Sector 01 [0670] 10123. Fragmento de parede de pequena dimensão, correspondendo a possível de taça. Pasta de cor bege, dura, compacta e depurada. Verniz negro, aderente, espesso e brilhante. Não ilustrado. 
MAR/236 - C. Mar. 2003 Sector 01 [0648] 11709. Fragmento de parede de possível taça. Pasta de cor bege, dura e compacta. Verniz negro, aderente, espesso e baço. Não ilustrado.

MAR/237 - C. Mar. 2003 Sector 01 [0605] 12138. Fragmento de parede de possível taça. Pasta de cor laranja, dura, compacta e depurada. Verniz acinzentado, aderente e espesso. Não ilustrado.

MAR/238 - C. Mar. 2003 Sector 01 [0684] 11626. Fragmento de parede de possível taça. Pasta de cor laranja, dura e compacta. Verniz negro, aderente e espesso. Não ilustrado.

MAR/239 - C. Mar. 2002 Sector 01 [0592] 6060. Fragmento de parede de possível taça. Pasta de cor laranja, dura, compacta e depurada. Verniz negro, aderente e espesso. Não ilustrado.

MAR/240 - C. Mar. 2000 Sector 01 [0035] 770, 772, 773, 774. Conjunto de fragmentos de parede possivelmente pertencentes à mesma peça. Forma indeterminada. Pasta de cor laranja, dura, compacta e depurada. Verniz negro, aderente, espesso, brilhante, de boa qualidade. Apresenta uma linha em reserva na superfície exterior. Não ilustrado.

MAR/241 - C. Mar. 2002 Sector 01 [0591] 6097. Fragmento de parede de forma indeterminada. Pasta de cor laranja, dura e compacta. Verniz negro, aderente e espesso. Não ilustrado.

MAR/242 - C. Mar. 2002 Sector 01 [0526] 6251. Fragmento de parede e arranque de pé. Muito deteriorado e fraturado. Pasta de cor laranja, dura, compacta e depurada. Verniz negro, aderente, espesso e brilhante. Não ilustrado.

MAR/243 - C. Mar. 2002 Sector 01 [0588] 6039. Fragmento de fundo de forma indeterminada. Pasta de cor bege e tonalidade alaranjada, dura, compacta e depurada Verniz negro com manchas acastanhadas, aderente, pouco espesso e com brilho metalizado. O verniz apresenta-se muito deteriorado, particularmente no fundo externo. Não ilustrado.

MAR/244 - C. Mar. 2003 Sector 01 [0684] 11625. Fragmento de fundo e arranque de pé de forma indeterminada. O fundo externo apresenta-se em reserva. Pasta de cor laranja, dura e compacta. Verniz negro, aderente e espesso. Não ilustrado.

MAR/245 - C. Mar. 2000 Sector 01 [0014] 1349. Fragmento de forma indeterminada. Pasta e cor laranja, dura e compacta. Verniz negro, espesso, aderente e brilhante, com ligeiro brilho metálico. Não ilustrado.

MAR/246 - C. Mar. 2003 Sector 01 [0691] 11703. Fragmento de parede e arranque de fundo de forma indeterminada. Pasta de cor bege e tonalidade alaranjada, dura, compacta e depurada. Verniz negro com manchas acinzentadas na superfície externa, aderente, espesso e pouco brilhante. Não ilustrado.

MAR/247 - C. Mar. 1987 Corte 03 Quadrado C 04 Nível 03 2848. Fragmento de parede de forma indeterminada. Pasta de cor laranja clara. Verniz negro, aderente, espesso, de boa qualidade. Não ilustrado.

MAR/248 - C. Mar. 2000 Sector 01 [Sup.] 1350. Fragmento de parede de forma indeterminada. Pasta de cor bege, dura e compacta. Verniz negro, aderente, espesso e brilhante. Não ilustrado.

MAR/249 - C. Mar. Sup. 3622. Fragmento de pequena dimensão correspondendo a parede de forma indeterminada. Encontra-se em avançado estado de deterioração. Pasta de cor bege, dura, compacta e depurada. Verniz negro, aderente, espesso e brilhante. Não ilustrado. 
MAR/250 - C. Mar. 2002 Sector 01 [0526] 6090. Fragmento de parede. Pasta de cor laranja, dura e compacta. Verniz negro, aderente e espesso. Não ilustrado.

MAR/251 - C. Mar. 2002 Sector 01 [0530] 6105. Dois fragmentos pertencentes à mesma peça, correspondendo a parede de forma indeterminada. Apresenta uma linha reservada, na superfície externa junto à zona de fratura do fragmento, com cerca de $1 \mathrm{~mm}$ de espessura. Pasta de cor bege, dura, compacta e depurada. Verniz negro com manchas de tonalidade acinzentada. Verniz aderente, espesso e brilhante. Não ilustrado.

MAR/252 - C. Mar. 2002 Sector 01 [0588] 6083. Fragmento de pequena dimensão de forma indeterminada. Não conserva espessura. Pasta de cor laranja, dura, compacta e depurada. Verniz negro, aderente, espesso e brilhante. Não ilustrado.

MAR/253 - C. Mar. 2002 Sector 01 [0450] 6013. Fragmento de parede de forma indeterminada. Pasta de cor bege e tonalidade alaranjada, dura, compacta e depurada. Verniz negro, espesso, aderente, de boa qualidade. Não ilustrado.

MAR/254 - C. Mar. 1987 Corte 03 Quadrado C 05 Nível 01 2853. Fragmento de parede de forma indeterminada. Pasta de cor bege, dura, compacta e depurada. Verniz negro, aderente e espesso. Não ilustrado. Não ilustrado.

MAR/255 - C. Mar. 1987 Corte 03 Quadrado B 06 Nível 02 2844. Fragmento de parede de forma indeterminada. Pasta de cor bege, dura e compacta. Verniz negro, aderente e espesso. Não ilustrado.

MAR/256 - C. Mar. 1987 Corte 03 Quadrado B 06 Nível 02 2828. Fragmento de parede de forma indeterminada. Pasta de cor bege, dura e compacta. Verniz negro, aderente e espesso. Não ilustrado.

MAR/257 - C. Mar. 2003 Sector 01 [0744] 11630. Fragmento de parede de possível taça. Pasta de cor laranja, dura e compacta. Verniz negro, de tonalidade acinzentada na superfície interior, aderente, espesso e baço. Não ilustrado.

MAR/258 - C. Mar. 2003 Sector 01 [0617] 11629. Fragmento de parede de forma indeterminada. Pasta de cor bege e tonalidade alaranjada, dura e compacta e depurada. Verniz cinzento, aderente e pouco espesso. Não ilustrado.

MAR/259 - C. Mar. 2000 Sector 01 [Sup.] 1348. Fragmento de parede de forma indeterminada. Pasta de cor laranja, dura e compacta. Verniz negro, aderente, espesso e brilhante. Não ilustrado.

MAR/260 - C. Mar. 2000 Sector 01 [0089] 1628. Fragmento de fundo de forma indeterminada. A superfície externa apresenta-se reservada. Pasta de cor bege, dura, compacta e depurada. Verniz negro, aderente, espesso e brilhante. Não ilustrado.

MAR/261 - C. Mar. 1987 Corte 03 Quadrado D 04 Nível 01 2849. Fragmento de parede de forma indeterminada. Pasta de cor bege, dura, compacta e depurada. Verniz negro, aderente, espesso e brilhante, de brilho ligeiramente metalizado. Não ilustrado.

MAR/262 - C. Mar. 2002 Sector 01 [0609] 7958. Fragmento de parede de forma indeterminada. Não conserva espessura. Pasta de cor laranja, dura e compacta. Verniz negro, aderente, espesso e brilhante. Não ilustrado. 
MAR/263 - C. Mar. 2002 Sector 01 [0360] 3971. Fragmento de parede de pequena dimensão de forma indeterminada. Pasta de cor bege, dura, compacta e depurada. Verniz negro, aderente, espesso e brilhante. Não ilustrado.

MAR/264 - C. Mar. 2002 Sector 01 [0089] 8010. Fragmento de pequena dimensão, de parede, próxima do arranque de fundo. Forma indeterminada. Pasta de cor bege, dura, compacta e depurada. Verniz negro, aderente, espesso e brilhante. Não ilustrado.

MAR/265 - C. Mar. 2002 Sector 01 [0389] 5843. Fragmento de parede de pequena dimensão de forma indeterminada. Não conserva espessura. Pasta de cor laranja, dura, compacta e depurada. Verniz negro, aderente, espesso e brilhante. Não ilustrado.

MAR/266 - C. Mar. 1987 Corte 03 Quadrado C 06 Nível 01 2838. Fragmento de parede de pequena dimensão de forma indeterminada. Pasta de cor bege, dura, compacta e depurada. Verniz negro, aderente, espesso e brilhante. Não ilustrado.

MAR/267 - C. Mar. 2002 Sector 01 [0526] 6089. Fragmento de parede de forma indeterminada. Pasta de cor bege e tonalidade amarelada, dura, compacta e depurada. Verniz negro, aderente, espesso e brilhante, com ligeiro brilho metalizado. Não ilustrado.

MAR/268 - C. Mar. 2001 Sector 01 [0143] 3137. Fragmento de parede de forma indeterminada. Pasta de cor bege, dura, compacta e depurada. Verniz negro, aderente, espesso e brilhante. Não ilustrado.

MAR/269 - C. Mar. 1986 Corte 01 Quadrado E 01 Nível 06 2854. Fragmento de parede de forma indeterminada. Pasta de cor bege, dura, compacta e depurada. Verniz negro, aderente, espesso e brilhante. Não ilustrado.

MAR/270 - C. Mar. 2002 Sector 01 [0478] 5424. Fragmento de parede de pequena dimensão de forma indeterminada. Pasta de cor bege, dura, compacta e depurada. Verniz negro, aderente, espesso e brilhante. Não ilustrado.

MAR/271 - C. Mar. 2002 Sector 01 [0592] 6019. Fragmento de parede de forma indeterminada. Pasta de cor laranja, dura, compacta e depurada. Verniz negro, aderente, espesso e pouco brilhante. Não ilustrado.

MAR/272 - C. Mar. 1987 Corte 03 Quadrado C 04 Nível 03 2846. Fragmento de pequena dimensão de forma indeterminada. Pasta de cor laranja, dura, compacta e depurada. Verniz negro, aderente, espesso e pouco brilhante. Não ilustrado.

MAR/273 - C. Mar. 2000 Sector 01 [0037] 0905. Fragmento de parede de forma indeterminada. Pasta de cor laranja, dura, compacta e depurada. Verniz negro, aderente, espesso e brilhante. Não ilustrado.

MAR/274 - C. Mar. 1986 Corte 03 Quadrado D 03 Nível 04 2847. Fragmento de parede de forma indeterminada. Pasta de cor laranja, dura, compacta e depurada. Verniz negro, aderente, espesso e brilhante. Não ilustrado.

MAR/275 - C. Mar. Sup. 5384. Fragmento de fundo de forma indeterminada. Pasta de cor laranja e cinzento, dura e compacta. Verniz negro, aderente, espesso e brilhante. Apresenta o fundo externo em reserva, decorado com círculos concêntricos em verniz negro. Não ilustrado. 
MAR/276 - C. Mar. 2002 Sector 01 [0292] 2149. Fragmento de parede de forma indeterminada. Pasta de cor bege, dura, compacta e depurada. Verniz negro, aderente, espesso e brilhante. Não ilustrado.

MAR/277 - C. Mar. 1987 Corte 03 Quadrado D 04 Nível 01 9079. Fragmento de pequena dimensão de fundo de possível taça. Pasta de cor bege e tonalidade alaranjada, dura, compacta e depurada. Verniz negro, aderente, espesso e brilhante. Não ilustrado.

MAR/278 - C. Mar. 2002 Sector 01 [0478] 6064. Fragmento de parede e possível arranque de fundo. O fundo exterior apresenta-se envernizado. Apresenta uma banda em reserva, na superfície interior, na ligação da parede ao fundo. Pasta de cor bege e tonalidade alaranjada, dura, compacta e depurada. Verniz negro, aderente, espesso e brilhante. Não ilustrado.

\subsubsection{As asas}

São trinta e um os fragmentos de asas recolhidos no Castelo de Castro Marim (nove indivíduos), tendo sido possível distinguir os que pertenceram a skyphoi/bolsais (oito) dos que fizeram parte integrante de kilikes de variante indeterminada (22). Esta proporção, uma larga maioria de asas de taças versus um menor número de skyphoi/bolsais, está de acordo com a que se verificou para as contagens que diziam respeito aos bordos. Os próprios contextos de recolha permitem admitir que uma considerável quantidade das primeiras eram parte integrante de taças Cástulo.

\section{Catálogo}

MAR/279 - C. Mar. 2002 Sector 01 [0360] 3968. Fragmento de asa de skyphos ou bolsal. Pasta de cor laranja, dura e compacta. Verniz negro, aderente e espesso. Apresenta a parte interior da asa em reserva. Não ilustrado.

MAR/280 - C. Mar. 2002 Sector 01 [0526] 6038. Fragmento de asa de perfil oval e configuração recta, podendo corresponder a skyphos ou bolsal. Pasta de cor laranja, dura, compacta e depurada. Verniz negro com manchas avermelhadas, aderente e pouco espesso. Apresenta a parte interior da asa em reserva. Não ilustrado.

MAR/281 - C. Mar. 2002 Sector 01 [0572] 6085. Fragmento de asa de perfil oval alongado podendo corresponder a skyphos ou bolsal. Pasta de cor laranja, dura e compacta. Verniz negro, aderente e espesso. Apresenta-se totalmente envernizado. Não ilustrado.

MAR/282 - C. Mar. 1984 Corte 01 Quadrado E 02 Sem nível 3744. Fragmento de asa de perfil oval alongado podendo corresponder a skyphos ou bolsal. Pasta de cor laranja, dura, compacta e depurada. Verniz negro, aderente, espesso e brilhante. Apresenta-se totalmente envernizado. Não ilustrado.

MAR/283 - C. Mar. 1984 Corte 01 Quadrado E 02 Nível 03 3735. Fragmento de asa de perfil oval e configuração recta, podendo corresponder a um skyphos ou bolsal. Pasta de cor laranja, dura, compacta e depurada. Verniz negro, muito deteriorado. Apresenta-se totalmente envernizado. Não ilustrado.

MAR/284 - C. Mar. 2002 Sector 01 [0360] 6022. Fragmento de asa de perfil oval e configuração recta, podendo corresponder a um skyphos ou bolsal. Pasta de cor laranja, dura, compacta e depurada. Verniz negro com manchas avermelhadas. O avançado estado de deterioração do verniz não permite identificar áreas em reserva. Não ilustrado.

MAR/285 - C. Mar. 1983 Corte 01 Quadrado E 03 Nível 04 2840. Fragmento de asa de secção oval 
alongada podendo corresponder a skyphos ou bolsal. Pasta de cor laranja, dura e compacta. Verniz negro com manchas avermelhadas, aderente e espesso. Apresenta-se totalmente envernizado. Não ilustrado.

MAR/286 - C. Mar. 2002 Sector 01 [0503] 6014. Fragmento de pequena dimensão, correspondendo a asa de forma indeterminada. Pasta de cor laranja, dura, compacta e depurada. Verniz negro, muito deteriorado, não permitindo confirmar se o interior se encontra em reserva. Não ilustrado.

MAR/287 - C. Mar. 1983 Corte 01 Quadrado E 03 Nível 04 2836. Fragmento de asa de perfil oval e configuração retilínea podendo corresponder a skyphos ou bolsal. Pasta de cor laranja, dura, compacta e depurada. Verniz negro, espesso, aderente e brilhante. Apresenta a parte interior da asa em reserva. Não ilustrado.

MAR/288 - C. Mar. 2002 Sector 01 [0503] 6023. Fragmento de asa possivelmente pertencente a uma kylix. Pasta de cor laranja, dura, compacta e deputada. Verniz negro, muito deteriorado. Apresenta-se totalmente envernizado. Não ilustrado.

MAR/289 - C. Mar. 2000 Sector 01 [0089] 0902. Fragmento de asa de secção oval alongada, pertencente a uma kylix. Pasta de cor laranja, dura e compacta. Verniz negro, aderente e espesso. Apresenta a parte interior da asa em reserva. Não ilustrado.

MAR/290 - C. Mar. 1987 Corte 03 Quadrado E 06 Nível 01 2841. Fragmento de asa pertencente a uma kylix. Pasta de cor laranja, dura e compacta. Verniz negro, aderente, espesso e muito deteriorado. Apresenta-se totalmente envernizado. Não ilustrado.

MAR/291 - C. Mar. 2000 Sector 01 [0089] 0881. Fragmento de asa de secção oval. pertencente a uma kylix. Pasta de cor laranja, dura e compacta. Verniz negro, aderente e espesso. Apresenta a parte interior da asa em reserva. Não ilustrado.

MAR/292 - C. Mar. 1987 Corte 03 Quadrado D 04 Nível 01 9082. Fragmento de asa de secção oval pertencente a uma kylix. Pasta de cor laranja, dura e compacta. Verniz vermelho, aderente e pouco espesso. Apresenta-se totalmente envernizado. Não ilustrado.

MAR/293 - C. Mar. 2000 Sector 01 [0089] 1064. Fragmento de asa pertencente a uma kylix. Pasta de cor laranja, dura e compacta. Verniz negro, aderente e espesso. Apresenta-se totalmente envernizado. Não ilustrado.

MAR/294 - C. Mar. 2003 Sector 01 [Sup.] 10198. Fragmento de asa de perfil oval pertencente a uma kylix. Pasta de cor laranja, dura, compacta e depurada. Verniz negro, aderente, espesso e brilhante. Apresenta-se totalmente envernizado. Não ilustrado.

MAR/295 - C. Mar. 2003 Sector 01 [0679] 11712. Fragmento de asa de perfil tendencialmente retangular, pertencente a uma kylix. Pasta de laranja, dura e compacta. Verniz negro com manchas acinzentadas e avermelhadas. Apresenta a parte interior da asa em reserva. Não ilustrado.

MAR/296 - C. Mar. 1987 Corte 03 Quadrado D 04 Nível 01 9083. Fragmento de asa de perfil oval, pertencente a uma kylix. Pasta de cor laranja, dura, compacta e depurada. Verniz negro, aderente, espesso e brilhante. Apresenta-se totalmente envernizado. Não ilustrado.

MAR/297 - C. Mar. 1984 Corte 01 Quadrado E 02 Nível 01 2832. Fragmento de asa de perfil oval, pertencente a uma kylix. Pasta de cor laranja, dura, compacta e depurada. Verniz negro, espesso 
e aderente. Apresenta-se totalmente envernizado. Não ilustrado.

MAR/298 - C. Mar. 2003 Sector 01 [0581] 6073. Fragmento de asa de secção oval, pertencente a uma kylix. Pasta de cor laranja, dura e compacta. Verniz negro, aderente e espesso. $\mathrm{O}$ avançado estado de deterioração do verniz não permite confirmar a existência de áreas em reserva. Não ilustrado.

MAR/299 - C. Mar. 2000 Sector 01 [0089] 0880. Fragmento de asa de perfil oval pertencente a uma kylix. Pasta de cor bege e tonalidade amarelada, dura, compacta e depurada. Verniz negro com manchas avermelhadas, muito deteriorado. Apresenta a parte interior da asa em reserva. Não ilustrado.

MAR/300 - C. Mar. 1987 Corte 03 Quadrado C 06 Nível 01 2839. Fragmento de asa de perfil oval pertencente a uma kylix. Pasta de cor laranja, dura e compacta. Verniz negro, espesso e aderente. Apresenta a parte interior da asa em reserva. Não ilustrado.

MAR/301 - C. Mar. 2002 Sector 01 [0385] 5899. Fragmento de asa de perfil oval pertencente a uma kylix. Pasta de cor laranja, dura, compacta e depurada. Verniz negro, muito deteriorado. Apresenta-se totalmente envernizado. Não ilustrado.

MAR/302 - C. Mar. 1988 Corte 03 Quadrado E 06 Nível 01 2851. Fragmento de pequena dimensão de kylix de perfil oval pertencente a uma taça. Pasta de cor laranja, dura e compacta. Verniz negro, aderente, espesso e baço. Apresenta-se totalmente envernizado. Não ilustrado.

MAR/303 - C. Mar. 2002 Sector 01 [0360] 3967. Fragmento de asa de secção triangular pertencente a uma kylix. Pasta de cor laranja, dura e compacta. Verniz negro, aderente e espesso. Apresenta a parte interior da asa em reserva. Não ilustrado.

MAR/304 - C. Mar. 1987 Corte 03 Quadrado D 04 Nível 01 9081. Fragmento de asa pertencente a uma kylix. Apresenta-se totalmente envernizado. Não ilustrado.

MAR/305 - C. Mar. 2000 Sector 01 [0089] 0882. Fragmento de asa de perfil oval pertencente a uma kylix. Pasta de cor laranja, dura e compacta. Verniz negro, espesso e aderente. Apresenta a parte interior da asa em reserva. Não ilustrado.

MAR/306 - C. Mar. 2002 Sector 01 [0618] 6188. Fragmento de asa pertencente a uma kylix. Pasta de cor laranja, dura, compacta e pouco depurada. Verniz negro, aderente, espesso e muito brilhante, de brilho ligeiramente metalizado. Apresenta a parte interior da asa em reserva. Não ilustrado.

MAR/307 - C. Mar. 2000 Sector 01 [Sup.] 0906. Fragmento de asa pertencente a uma kylix. Pasta de cor laranja, dura e compacta. Verniz negro, espesso e aderente. Apresenta-se totalmente envernizado. Não ilustrado.

MAR/308 - C. Mar. 2003 Sector 01 [0716] 10098. Fragmento de pequena dimensão correspondendo a asa pertencente a uma kylix. Pasta de cor laranja, dura, compacta e depurada. Verniz negro, pouco aderente e espesso. Apresenta-se totalmente envernizado. Não ilustrado.

MAR/309 - C. Mar. 2003 Sector 01 [0816] 10082. Fragmento de asa de secção oval pertencente a uma kylix. Pasta de cor laranja, dura e compacta. Verniz negro, aderente e espesso. Apresenta a parte interior da asa em reserva. Não ilustrado. 


\subsubsection{As ânforas gregas}

Como é habitual nos sítios ocidentais, as ânforas gregas são raríssimas em Castro Marim, tendo sido contabilizados cinco fragmentos, que correspondem a outros tantos indivíduos. Três são áticas (MAR/312, MAR/313, MAR/314,), uma é de proveniência coríntia (MAR/310) e a restante pode ter origem em Quios (MAR/311).

Os três fragmentos áticos são paredes e pertenceram a ânforas "à la brosse", estando o verniz negro da superfície externa bem conservado, apresentando-se, apesar de fino, aderente.

Este tipo de ânfora, que transportou o azeite ateniense desde pelo menos o século VI a.n.e., era desconhecido, até ao momento, no território actualmente português, sendo, na restante Península Ibérica, muito escasso, sobretudo nestas cronologias mais tardias, dos finais do século V e do IV a.n.e. (Rouillard 1991). A sua presença em Huelva (Rufete Tomico 1991) é, contudo, de valorizar neste contexto, dada a proximidade geográfica. Infelizmente, apenas um dos três fragmentos reconhecidos em Castro Marim, justamente o que marca a transição do colo para o corpo (MAR/314), foi recolhido em nível conservado, concretamente o que corresponde ao depósito já tantas vezes mencionado neste trabalho, onde, como se viu, convive com outros contentores (hispânicos), de tipo Pellicer B/C e Mañá Pascual A4 (série 11 de Ramón Torres) e vasos áticos de verniz negro (taças Cástulo, de tipo plain rim e da classe delicada), estando datado do último quartel do século $V$ a.n.e.

Um bordo de ânfora (MAR/310) parece caber no que foi considerado Tipo $C$ no naufrágio de El Sec (Arribas et al. 1986: 420- 422), ainda que a sua integração no Tipo B de Corinto não seja também impossível. O bordo é aplanado e o lábio, pendente, é plano-côncavo, sendo a partir dele que arrancaria a asa. Na face interna, na ligação do bordo à parede, é visível um ligeiro ressalto. A ausência das características caneluras profundas imediatamente a seguir ao bordo, típicas das Coríntias de tipo B, obrigam-nos a considerar a possibilidade de estarmos perante uma ânfora de tipo MGS III de Vandermersch (1994), cujo local de produção permanece ainda em debate. Recorde-se que esta morfologia concreta foi aproximada por V. Grace (1979) das séries áticas, mas apresenta muitos pontos em comum com as de tipo Coríntia B. A cronologia de ambas baliza-se entre o final do século $V$ a.n.e. e o último terço do século IV a.n.e., o que concorda com a datação da chegada dos produtos gregos à foz do Guadiana, produtos que incluíram o vinho, como este

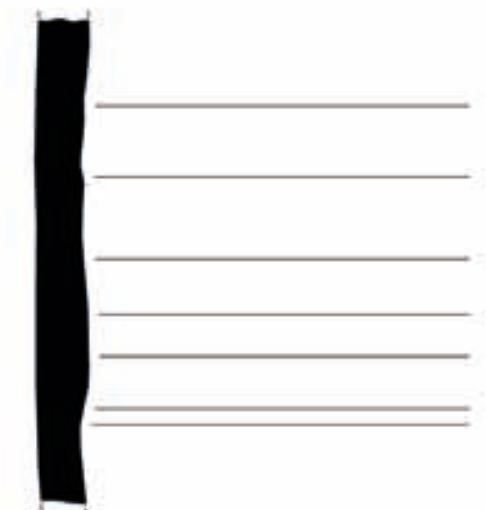

MARI73

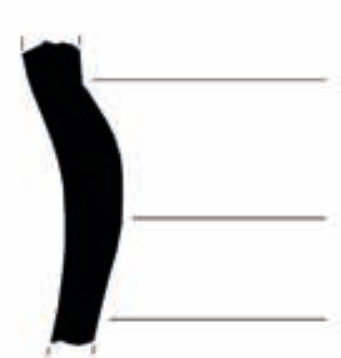

MAR/174

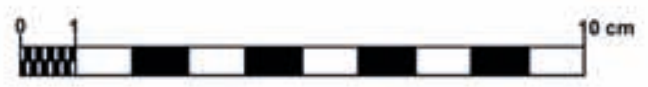

Fig. 46 - Fragmentos de ânforas áticas "à la brosse" do Castelo de Castro Marim. 

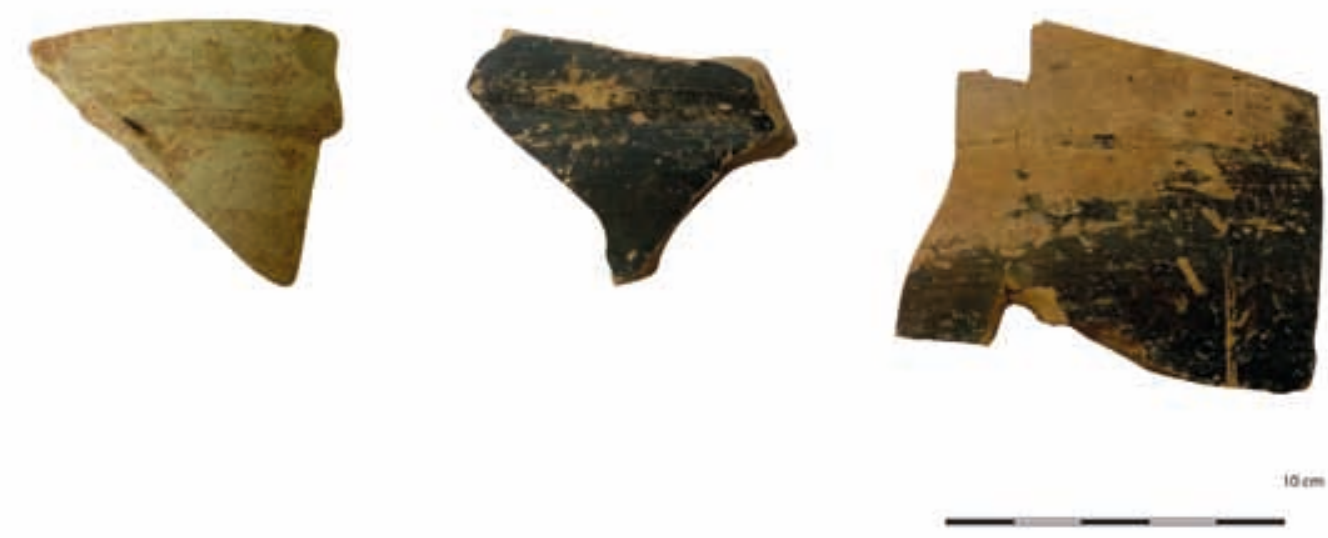

Fig. 47 - Ânforas gregas do Castelo de Castro Marim (fotografias de Elisa de Sousa).

caso concreto evidencia.

Uma outra ânfora grega foi identificada através de um fragmento de fundo (MAR/311). Com todas as reservas, consideramos a possibilidade de estarmos perante uma produção de Quios (Grace 1934: 201)*, correspondente ao tipo P da embarcação que naufragou em El Sec (Arribas et al. 1986: 465-468), o que se propõe não só pela morfologia concreta, mas também pelas características da pasta.

As ânforas gregas são, como acima se referiu, muito raras no Extremo Ocidente, havendo para o território português apenas a registar o exemplar de Monte Beirão, em Ourique (Beirão 1986), cuja classificação foi recentemente revista (Sousa - Arruda no prelo), tendo-se proposto o tipo N de El Sec (Arribas et al. 1986), de produção samia. Para o actual território espanhol, é obrigatório citar os exemplares da Andaluzia ocidental, muito especialmente os do Cerro Macareno (Pellicer - Escacena - Bendala 1983: Fig. 80), onde estão datados da segunda metade do século $V$ a.n.e.

\section{Catálogo}

MAR/310 - C. Mar. 1985 Corte 01 Quadrado Do3 Nível 04 4550. Bordo de ânfora de Tipo C de El Sec. Pasta bege esverdeado, dura e compacta.

MAR/311 - C. Mar. 2003 Sector 01 [0744] 14924. Fundo de ânfora de Tipo P de El Sec. Pasta laranja, dura e compacta.
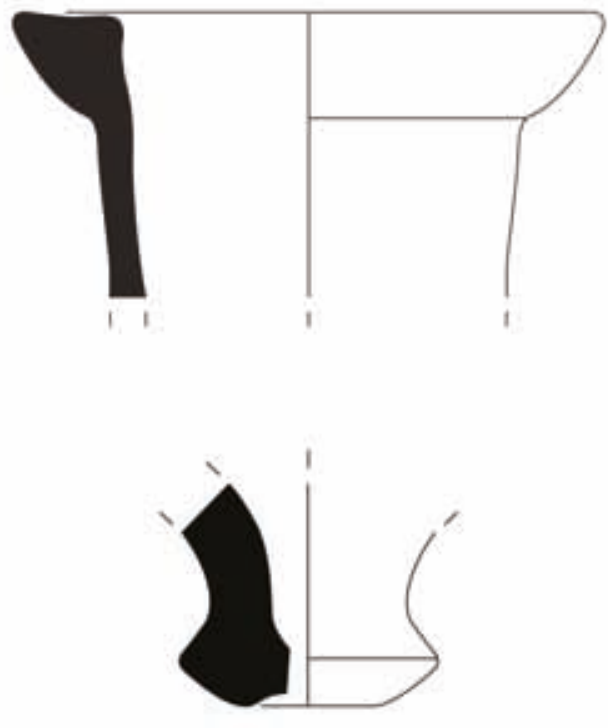

Fig. 48 - Ânfora do tipo B ou C de Corinto e fundo de ânfora de Quios. 
MAR/312 - C. Mar. 2000 Sector 01 [0060] 761. Dois fragmentos de parede de corpo de ânfora ática "à la brosse". Pasta de cor laranja, dura e compacta. Engobe negro, pouco espesso, mas aderente. Não ilustrado.

MAR/313 - C. Mar. 2000 Sector 01 [0109] 1700. Fragmento de parede de corpo de ânfora ática "à la brosse". Pasta de cor laranja acinzentada clara, dura e compacta. Engobe negro, pouco espesso, mas aderente. Não ilustrado.

MAR/314 - C. Mar. 2000 Sector 01 [0078] 4541. Fragmentos de parede de corpo e colo de ânfora ática "à la brosse". Pasta de cor laranja, dura e compacta. Engobe castanho, pouco espesso, mas aderente. Não ilustrado. 
$-\ldots, \cdots--x_{-\infty}-$

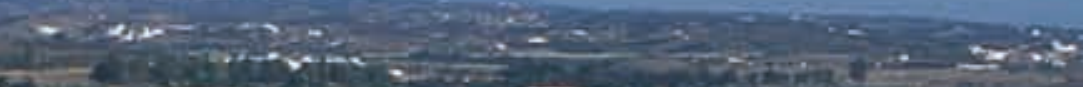

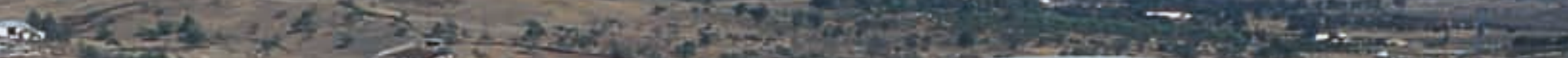

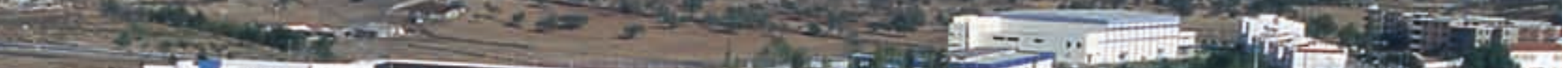
2.

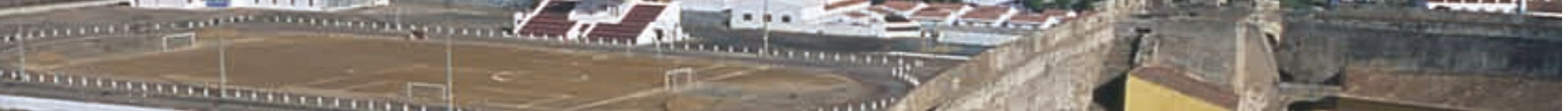

\section{$\mathrm{F}=\mathrm{x}$}

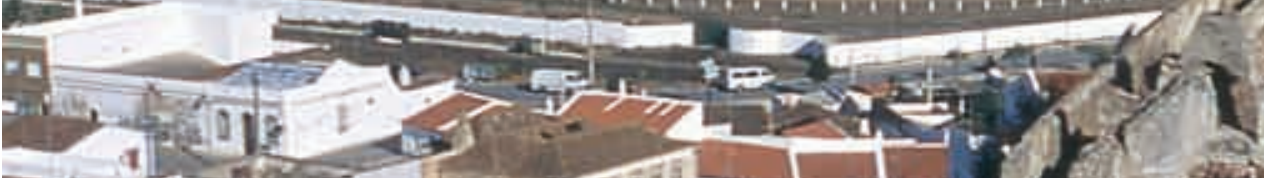

- is in

b.

$<+\frac{1}{1}>2 \%$

- ine

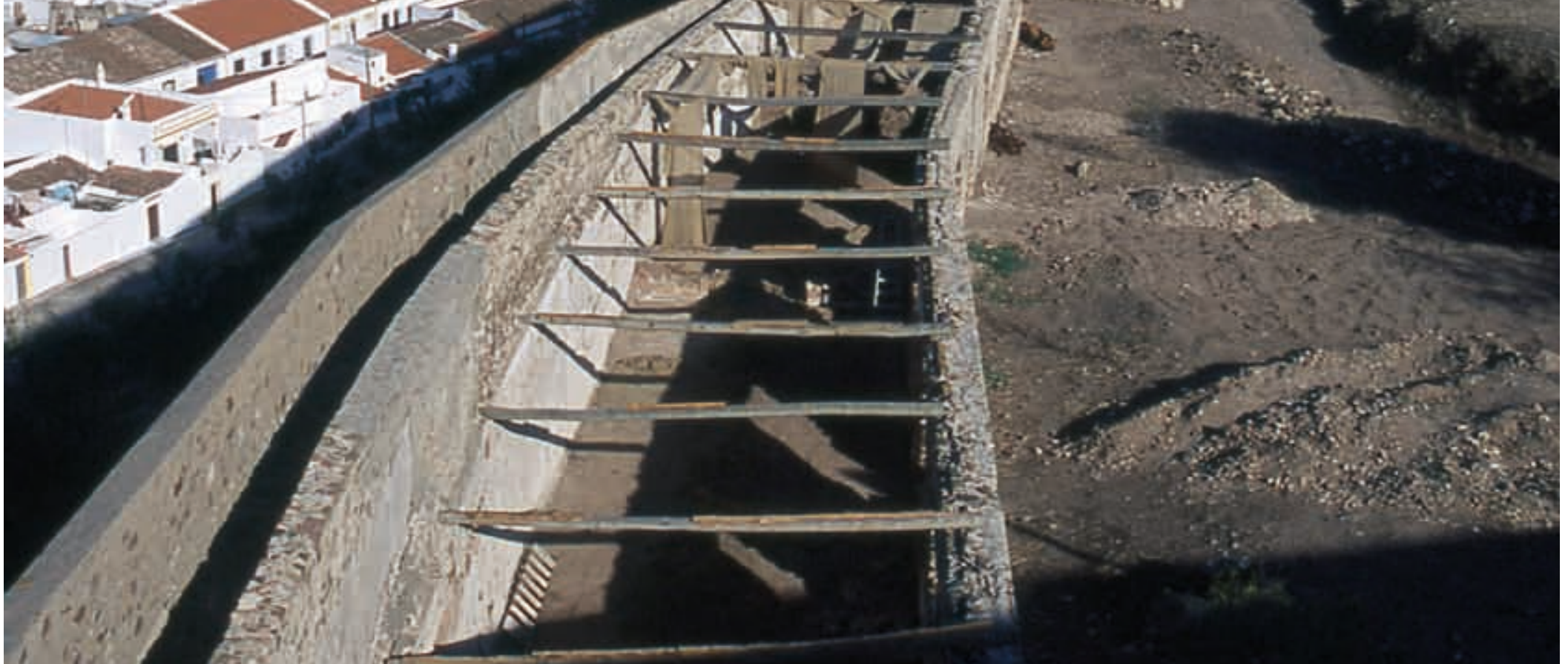





\section{Conclusão}

A cerâmica grega do Castelo de Castro Marim destaca-se, em primeiro lugar, pela sua abundância, sobretudo se tivermos em consideração a relativa escassez da área escavada. De facto, e para Portugal, corresponde ao maior conjunto de cerâmicas importadas, fundamentalmente, da Grécia continental, um número que não tem paralelo no Extremo Ocidente. Apenas Mértola, localizada a montante na mesma margem do rio, se aproxima dos valores obtidos no sítio da foz.

Pode, portanto, concluir-se que o uso de vasos decorados com Figuras Vermelhas e de verniz negro era relativamente comum e estava de alguma forma vulgarizado. Por outro lado, a integração da área meridional portuguesa nas redes comerciais do Mediterrâneo torna-se ainda mais clara, associando-se os dados agora publicados a outros, nomeadamente aos dos estudos efectuados sobre outros materiais, como é o caso das ânforas.

Como se pode constatar através dos paralelos que se estabeleceram para as peças que estudamos, a conexão de Castro Marim com o mundo dito turdetano e / ou gaditano fica ainda mais reforçada, realidade para a qual temos vindo a chamar a atenção desde há vários anos (Arruda 1997, 1999-2000, 2005; Sousa 2009; Sousa - Arruda 2010).

Castro Marim é também um dos poucos sítios portugueses que ofereceu cerâmica de Época Arcaica (Arruda 2019). Sobre esta última situação não há muito mais a comentar, para além do que foi já dito em 3.2. Trata-se da parede de um olpe de Figuras Negras de produção coríntia, datandose do segundo quartel do século VI a.n.e. A sua chegada à foz do Guadiana deve ser lida em função do abastecimento de produtos gregos às colónias fenícias da área do Estreito de Gibraltar, onde Castro Marim de alguma forma se insere, o que não se estranha dada a sua relativa abundância nas próprias metrópoles orientais. A situação não destoa, portanto, em termos contextuais do panorama peninsular, apesar da sua presença se ter documentado em contexto doméstico, o que, sendo raro, não é inédito.

Os dados analisados deixaram também claro que as importações de época clássica correspondem a duas fases distintas, que, contudo, se sucedem no tempo, sem quaisquer descontinuidades. Estas importações decorreram entre o último quartel do século $V$ a.n.e. e os meados da centúria seguinte, portanto durante 75 anos, mas os materiais encontram-se, 


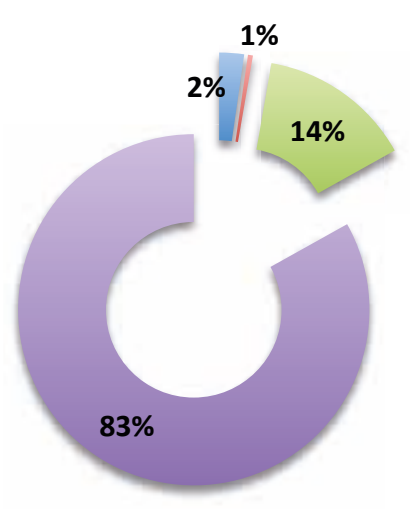

Ânforas $\square$ FN FV $\square$ VN

Fig. 49 - Distribuição da cerâmica grega do Castelo de Castro Marim segundo as respectivas categorias (base NMI).

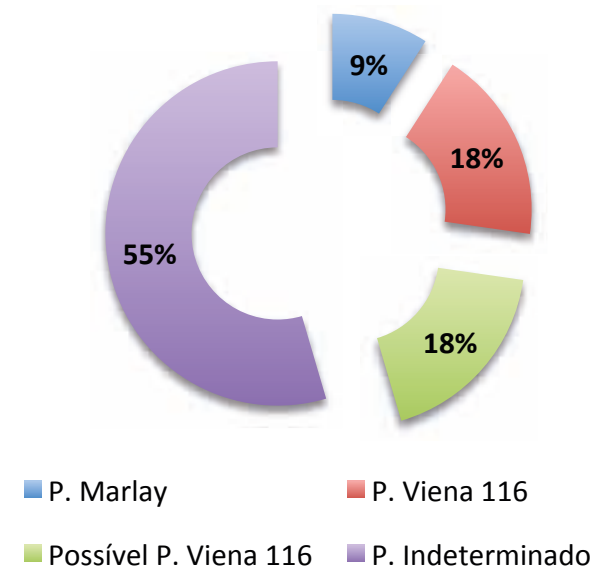

Fig. 50 - Distribuição da cerâmica ática de figuras vermelhas de acordo com os pintores representados (base NMI). maioritariamente, diferenciados do ponto de vista estratigráfico, como houve oportunidade de evidenciar na análise contextual que realizámos para cada forma.

À primeira fase (último quartel do século $\checkmark$ a.n.e.) pertencem seguramente as taças Cástulo, as da Classe Delicada e as plain rim cups, alguns skyphoi, a lekanis e os bolsais de curvatura única, no grupo das de verniz negro; os skyphoi com grinaldas de folhas de murta pintadas e algumas kilikes, no que se refere aos vasos decorados com figuras vermelhas.

Na primeira metade do século IV a.n.e., as importações constam de taças decoradas com Figuras Vermelhas (a maior parte pintadas pelo grupo do Pintor de Viena 116), e, no caso das de verniz negro, das páteras 21 e 22, muitas das quais com decoração estampilhada no fundo interno, dos pratos de peixe e dos da forma Jehasse 116, dos skyphoi com parede de dupla curvatura, e das pequenas taças da forma 21/25B. Atendendo aos contextos de recolha dos materiais, parece possível admitir que algumas taças Cástulo e pelo menos um dos bolsais pertencem ainda a esta fase.

Estas importações do século IV devem ter chegado à foz do Guadiana em pelo menos dois momentos distintos, $1^{\circ}$ e $2^{\circ}$ quartéis, se tivermos em consideração as observações cronológicas de P. Cabrera Bonet (1997: 380). Como se referiu no parágrafo anterior, os dados estratigráficos permitem igualmente aceitar esta proposta sem grandes reservas, sendo esta realidade também sugerida por outro tipo de evidências. Assim, se parece certo que algumas das taças Cástulo, um dos bolsais e os pratos de peixe de bordo pendente terão sido importados nas primeiras três décadas do século IV a.n.e., tudo indica que os pratos de peixe de bordo apenas espessado, os pratos da forma Jehasse 116 e

as páteras 21 e 22 devem ser datados entre 370 e 350 a.n.e.

Em termos cronológicos, esta realidade não destoa da observada em outras áreas da Península Ibérica, mais ou menos próximas. Para o território português, recordamos as semelhanças com o conjunto de Mértola (Arruda - Barros - Lopes 1998), onde o quadro formal e as cronologias são quase rigorosamente idênticos, mas onde, infelizmente, não existem contextos seguros que ajudem na definição de cronologias mais precisas. Para o território espanhol, citem-se os casos paradigmáticos de Cancho Roano, na Extremadura espanhola (Gracia Alonso 2003) e de Zacatín, em Granada (Adroher Auroux - Sanchéz Moreno - Torre Castellano 2016), no que se refere aos séculos V e IV a.n.e., respectivamente.

Outro tipo de observações diz respeito à funcionalidade dos vasos áticos usados no Castelo de Castro Marim. No século V a.n.e., as importações são exclusivamente destinadas ao consumo 


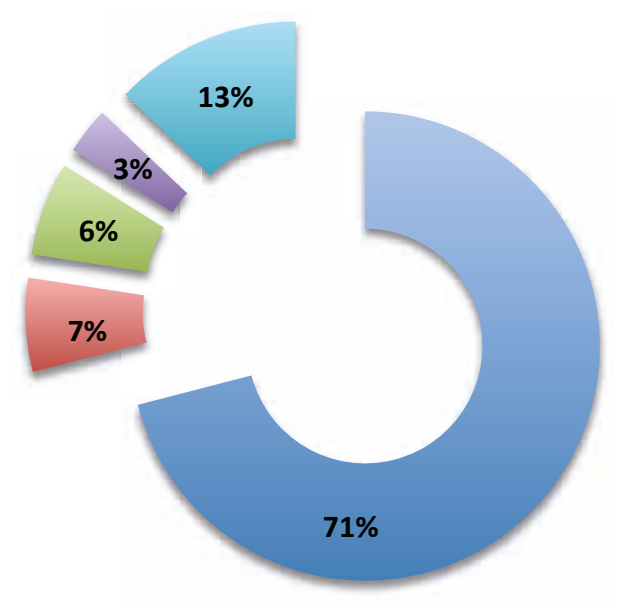

Kilikes Skyphoi Pelikai Lekythos Indeterminada

Fig. 51 - Distribuição da cerâmica ática de figuras vermelhas por formas (base NMI).

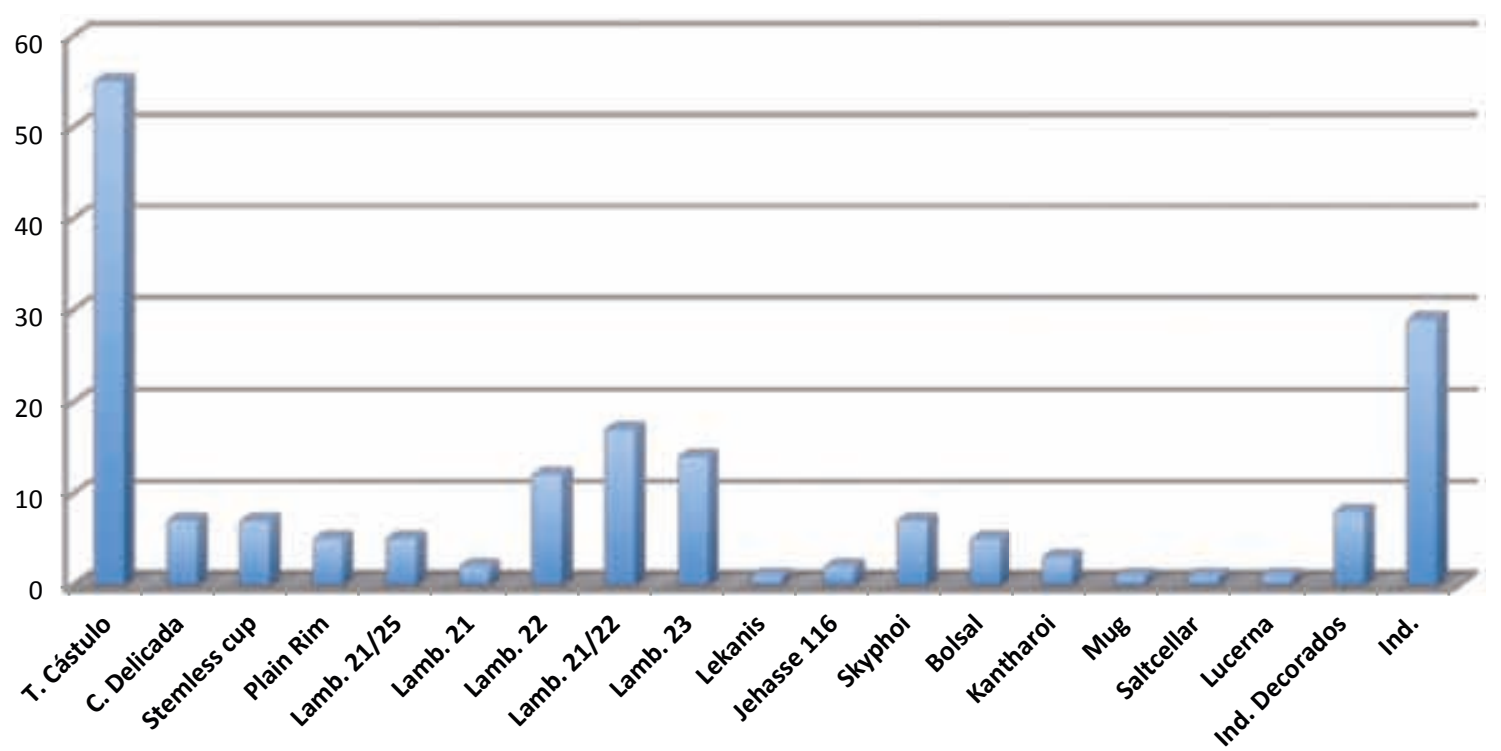

Fig. 52 - Distribuição da cerâmica ática de verniz negro por formas (base NMI).

de líquidos, concretamente de vinho, como fica comprovado pelas expressivas quantidades de taças Cástulo e das da Classe Delicada (em menor número), mas também das Kilikes pintadas com figuras vermelhas, dos skyphoi e dos bolsais.

Nos conjuntos do século IV a.n.e., os usos dos vasos parecem mais equilibrados. Os destinados ao consumo de alimentos sólidos parecem dominar, uma vez que aos pratos, de peixe e da forma Jeasse 116, podem somar-se as páteras da forma 21 e 22. As taças para beber são maioritariamente de Figuras Vermelhas, destacando-se as kilikes pintadas pelo Pintor de Viena 116.

Outras formas com funções mais diversificadas são numericamente irrelevantes, como é o caso da lekanis, dos kantharoi, da lekythos aribalística, da lucerna ou do "saltcellar".

Por último deve destacar-se a presença das ânforas gregas, áticas "à la brosse”, uma das 
quais recolhida em contexto datado do último quartel do século $V$ a.n.e., mas também coríntias e quiotas. Sendo raríssimas no actual território português, também não abundam na área da restante Península Ibérica, podendo deduzir-se que o vinho consumido nos vasos gregos era, na sua grande maioria, produzido localmente, ao contrário do que se verificava com outros produtos alimentares, como os piscícolas e oleícolas, transportados em ânforas gaditanas (Mañá Pascual A4) e turdetanas (Pellicer B/C e D).

O estudo dos materiais gregos recolhidos no Castelo de Castro Marim tornou ainda mais evidente a importância do sítio no contexto da Idade do Ferro do Sul de Portugal. O seu papel nas redes comerciais do Mediterrâneo Antigo e, em termos regionais, como centro redistribuidor de produtos manufacturados deve ser devidamente valorizado no quadro do protagonismo que as chamadas periferias desempenharam num mundo mais global durante $1^{\circ}$ milénio a.n.e., mesmo admitindo que estas se constituíram sobretudo enquanto "mercados".

As nossas últimas palavras são dirigidas a todos os colegas que connosco escavaram no Castelo de Castro Marim, a quem vivamente agradecemos, porque sem o seu trabalho este texto não teria sido possível. Todos perceberão que, entre esse vasto grupo, destaquemos a Vera e o Pipão, arqueólogos dedicados e escrupulosos, indelevelmente ligados ao projecto de Castro Marim, e, assim, à definição da sua muito discutida sequência estratigráfica e das diversas "fácies" estabelecidas, que tantas vezes foram usadas neste trabalho. À dedicação e empenho nos trabalhos de campo e de gabinete juntam-se a confiança e o respeito mútuos, que não agradecemos porque entram já também no domínio dos afectos, sem sombra de "pragmatismos" à custa dos quais se trocam princípios por vantagens imediatas. Associar o António (o Pardal) e o Chico a este grupo não precisa de qualquer justificação.

No "consulado" do Dr. José Estevens decorreram as escavações do início deste século, e não poderíamos esquecer que o apoio incondicional de todos os funcionários autárquicos foi fundamental para os resultados obtidos. Para além do então Presidente, os vereadores Nuno e Filomena estiveram sempre presentes. A esta última agradecemos também a colaboração na edição deste livro, sem a qual não teria sido possível a sua publicação.

Ao Professor Victor S. Gonçalves estamos gratas pelas fotografias das peças que, com engenho e arte, realizou, e que ilustram este trabalho. 


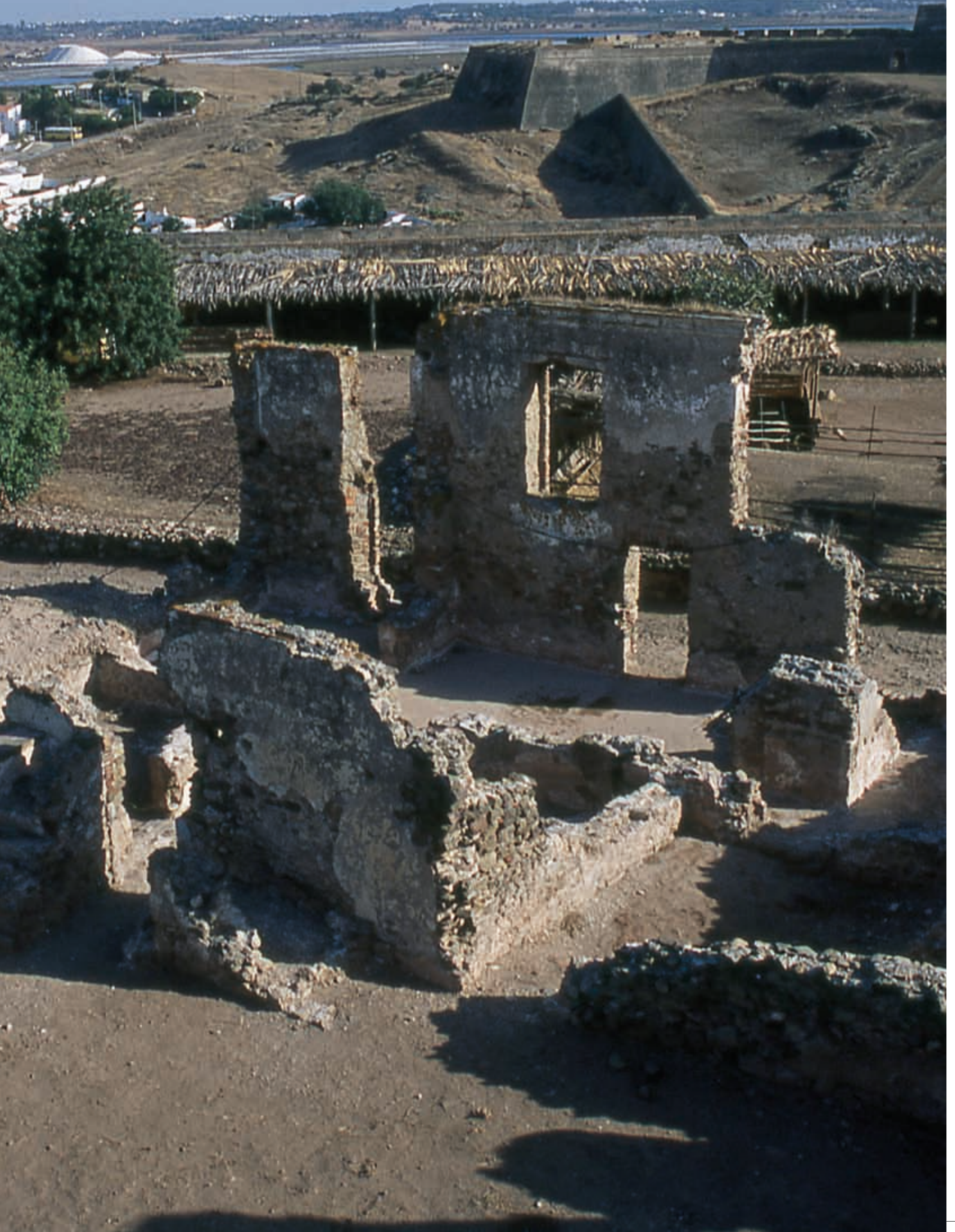





\section{Bibliografia}

Abreviaturas

ARV2 - J. D. Beazley (1968). Attic red-figure Vase-Painters. Oxford.

CVA - Corpus Vasorum Antiquorum.

Referências

Adroher Auroux, A. M. - Sánchez Moreno, A. - Torre Castellano, I. (2016) - Cerámica ática de barniz negro de Iliberri (Granada, España). Análisis crono-estadístico de un contexto cerrado. Portugalia. Nova Série 37: 5-38.

Amo de la Hera, M. (1970) - La céramica campaniense de importación y las imitaciones campanienses de Ibiza. Trabajos de Prehistoria 27: 201-244.

Amyx, D. A. - Lawrence, P. (1975) - Archaic corinthian pottery and the anaploga well. Corinth, results of excavations conducted by the America School of Classical Studies at Athens (vols. VII, part II). Princeton - New Jersey.

Arcelin, P. - Truffeau-Libre, M. (1998) - La quantifications des céramiques. Conditions y protocole. Bibracte (2).

Arribas, A. - Trías, G. - Cerdá, D. - De Hoz, J. (1987) - El barco de el Sec (Costa de Calvia, Mallorca): estudio de los materiales. Mallorca.

Arruda, A. M. (1997) - As cerâmicas áticas do Castelo de Castro Marim no quadro das exportações gregas para a Península Ibérica. Lisboa.

Arruda, A. M. (1999/2000) - Los fenícios en Portugal: Fenícios y mundo indígena en el centro y sur de Portugal (siglos VIII-VI a.C.). Barcelona (Cuadernos de Arqueología Mediterránea 5-6).

Arruda, A. M. (2000) - As cerâmicas de importação do Castelo de Castro Marim no âmbito do comércio ocidental dos séculos V a III a. C. In Aubet, M. E. - Barthélemy, M. (eds.) - Actas del IV Congreso Internacional de Estudios Fenicios y Púnicos: Cádiz, 2 al 6 de Octubre de 1995. Madrid-Cádiz (2): $727-735$.

Arruda, A. M. (2003) - Escavações arqueológicas no Castelo de Castro Marim. Balanço e perspectivas. Xelb 4: 71-88.

Arruda, A. M. (2005) - O $1^{\circ}$ Milénio a.n.e. no Centro e no Sul de Portugal: leituras possíveis no início de um novo século. O Arqueólogo Português 4-23: 9-156.

Arruda, A. M. (2007a) - A Idade do Ferro do Sul de Portugal. Estado da investigação. Madrider Mitteilungen 42: 114-139.

Arruda, A. M. (2007b) - A Idade do Ferro no Algarve: velhos dados (e outros mais recentes) e novas histórias. Xelb 7: 116-130.

Arruda, A. M. (2007c) - Cerâmicas gregas encontradas em Portugal. In Pereira, M. H. (ed.), Vasos gregos em Portugal - Aquém das colunas de Hércules. Lisboa: 135-149. 
Arruda, A. M. (2008a) - Fenícios e púnicos em Portugal: problemas e perspectivas. In Vita, J. P. - Zamora, J. Á. (eds.) - Nuevas perspectivas II: la arqueología fenicia y púnica en la Península lbérica. Barcelona: 13-23.

Arruda, A. M. (2008b) - O Baixo Guadiana durante os seculos VI e V a.n.e. In Jiménez Ávila, J. (ed.) - Sidereum Ana I. El río Guadiana en época post-orientalizante. Madrid: 307-325 (Anejos de Archivo Espanol de Arqueología XLVII).

Arruda, A. M. (2009) - Phoenician colonization on the Atlantic coast of the Iberian Peninsula. In Dietler, M. - López Ruiz, C. (eds.) - Colonial Encounters in Ancient Iberia. Chicago: 113-130.

Arruda, A. M. (2014) - Imagens de Astarté: pendentes de vidro da Idade do Ferro. In Badenás de la Peña, P. -Cabrera Bonet, P. - Moreno, M. (eds.) - Per speculum in aenigmate, miradas sobre la Antigüedad. Madrid: 273-278 (Anejos de Erytheia 7).

Arruda, A. M (2019) - A cerâmica grega de época arcaica do território actualmente português. Archivo Español de Arqueologia 92: 63-79.

Arruda, A. M. - Barros, P. - Lopes, V. (1998) - Cerâmicas áticas de Mértola. Conímbriga 37: 122149.

Arruda, A. M. - Freitas, V. (2008) - O Castelo de Castro Marim durante os séculos VI e V a.n.e. In Jimenez Avila, J. (ed.) - Sidereum Ana I. El río Guadiana en época post-orientalizante. Madrid: 429446 (Anejos de Archivo Espanol de Arqueología XLVII).

Arruda, A. M. - Freitas, V. - Oliveira, C. - Sousa, E. - Lourenço, P. - Carretero, P. (2009) - Castro Marim: um santuário pré romano na foz do Guadiana. In Mateos, P. - Celestino Pérez, S. - Pizzo, A. - Tortosa, T. (eds.) - Santuarios, Oppida y Ciudades: Arquitectura Sacra en el origen y desarrollo urbano del Mediterráneo Occidental. Simposio Internacional de Arqueología de Mérida, 4, 2006. Mérida: 79-88 (Anejos de Archivo Espanol de Arqueología XLV).

Arruda, A. M. - Oliveira, C. - Freitas, V. (2017)- Castro Marim entre indígenas, fenícios e tartésicos. In Ávila, J. J. (ed) - Sidereum Ana III. El río Guadina y Tartessos. Mérida: 445-466.

Arruda, A. M. - Soares, A. M. - Freitas, V. - Oliveira, C. - Martins, J. - Portela, P. (2013) - A cronologia relativa e absoluta da ocupação sidérica do Castelo de Castro Marim. Saguntum 45: 101-114.

Arruda, A. M. - Sousa, E. (2018) - Greek pottery in the Tagus estuary. In Morais, R. - Leão, D. Pérez, D. - Ferreira, D. (eds.) - Greek Art. Studies in honour of Sir John Boardman on the occasion of his 9oth birthday. Oxford: 187-195.

Arruda, A. M. - Sousa, E. - Barradas, E. - Batata, C. - Detry, C. - Soares, R. (2017) - O Cabeço Guião (Cartaxo, Portugal). Um sítio da Idade do Ferro do vale do Tejo. In Celestino, S. - Rodriguez, E. (eds.) - Território comparados: los valles del Guadalquivir, el Guadiana y el Tajo em época tartésica. Mérida: 319-361 (Anejos de Archivo Espanol de Arqueología LXXX).

Arruda, A. M. - Sousa, E. - Pereira, C. - Lourenço, P. (2011) - Monte Molião: um sítio púnicogaditano no Algarve (Portugal). Conimbriga 50: 5-32.

Arruda, A. M. - Viegas, C. - Bargão, P. - Pereira, R. (2006) - A importação de preparados de peixe em Castro Marim: da Idade do Ferro à época romana. Setúbal Arqueológica 13: 153-176.

Barros, P. (2003) - As cerâmicas áticas de Tavira. In Tavira: território e poder. Lisboa: 73-75.

Barros, P. (2005) - As cerâmicas áticas no circuito do estreito do extremo Ocidente Peninsular: Quinta da Queimada, Ilhéu do Rosário, Faro e Tavira. In Celestino, S. - Jiménez, J. (eds.) - El período orientalizante. Mérida: 931-945 (Anejos de Archivo Espanol de Arqueología 35).

Barros, P. (2010) - Mértola entre os séculos VI e III a.C. Mainake 32-1: 417-436.

Beirão, C. M. (1986) - Une civilisation Protohistorique du Sud du Portugal - 1er Age du Fer. Paris. Beirão, C. - Correia, V. H. (1991) - A cronologia do povoado de Fernão Vaz. Conimbriga 30: 5-11. Bonet, H. (1995) - El Tossal de Sant Miguel de Llíria. La antigua Edeta y su territorio. Valencia.

Cabrera, P. (1997) - La presencia griega en Andalucía (siglos VI al IV a.C.). In Fernández Jurado, R. - Sanz, G. (Eds) - La Andalucía Ibero-Turdetana (siglos VIIIV a.C.). Huelva: 367-390 (Huelva Arqueológica XIV).

Cabrera, P. - Perdigones, L. (1996) - Importaciones áticas del siglo V a.C. del Cerro del Prado (Algeciras, Cádiz). Trabajos de Prehistoria 53-2: 157-165.

Calado, D. - Gomes, M. V. (2006) - Quinta da Queimada (Lagos): a necrópole da II Idade do 
Ferro. Revista Portuguesa de Arqueologia 9-2: 171-175.

Cuadrado, E. (1963) - Cerámica ática de barniz negro de la necrópolis de El Cigarralejo, em Mula (Murcia). Arch. de Prehist. Levantina 10: 97-164.

Davis, S. (2007) - The mammals and birds from the Iron Age and Roman periods of Castro Marim, Algarve, Portugal. Lisboa (Trabalhos do CIPA 107).

Estrela, S. (2010) - Os níveis fundacionais da Idade do Ferro de Mesas do Castelinho (Almodôvar).

Os contextos arqueológicos na (re)construção do povoado. Lisboa (Dissertação de Mestrado em Arqueologia apresentada à Faculdade de Letras da Universidade de Lisboa).

Fernández Ochoa, C. - Caballero Klink, A. (1988) - El horizonte histórico de La Bienvenida y su posible identificación con la antigua Sisapo. In I Congreso de Historia de Castilla-La Mancha IV - Romanos y Visigodos: Hegemonía cultural y cambios sociales (Ciudad Real, 1985). Ciudad Real: 201210.

Freitas, V. T. (2005) - A cerâmica de engobe vermelho do Castelo de Castro Marim. Produção, comsumo e comércio na Idade do Ferro Orientalizante Peninsular. Lisboa (Dissertação de Mestrado em Pré-História e Arqueologia apresentada à Faculdade de Letras da Universidade de Lisboa).

García Cano, J. M. (1982) - Cerámicas griegas de la región de Murcia. Murcia.

García Cano, J. M. (1997) - Las necrópolis ibéricas de Coimbra del Barraco Ancho (Jumilla, Murcia): las excavaciones y estudio analítico de los materiales. Murcia.

Gibson, C. - Correia, V. H. - Burgess, C. - Boardman, S. (1998) - Alto do Castelinho da Serra (Montemor-o-Novo, Évora, Portugal): a preliminary report on the excavations at the Late Bronze Age to Medieval site, 1990-1993. Journal of Iberian Archaeology 0: 189-244.

Gomes, M. - Gomes, R. - Beirão, C. (1986) - O Cerro da Rocha Branca (Silves): Resultados preliminares de três campanhas de escavações. In Actas do $4^{\circ}$ Congresso do Algarve. Silves: 77-83.

Grace, V. R. (1934) - Stamped Amphora Handles Found in 1931-1932. Hesperia 3: 197-310.

Grace, V. R. (1979) - Amphoras and the ancient wine trade. Athens.

Gracia Alonso, F. (1994) - Las copas de Cástulo en la Península Ibérica. Problemática y ensayo de clasificación. In Cabrera, P. - Olmos, R. - Sanmartí, E. (eds.) - Iberos y griegos: Lecturas desde la diversidad. Huelva: 175-200 (Huelva Arqueológica XIII-1).

Gracia Alonso, F. (2003) - Las cerámicas áticas del palacio-santuario de Cancho Roano. In Celestino, S. (ed.) - Cancho Roano VIII. Los materiales Arqueológicos I. Mérida: 23-194.

Gracia Alonso, F. (2005) - Las cerámicas griegas en el área occidental de la Península Ibérica entre los siglos VI y $\mathrm{V}$ a.C. El conjunto de materiales del palacio-santuario de Cancho Roano (Zalamea de la Serena, Badajoz). In Celestino, S. - Jiménez, J. (eds.) - El período orientalizante. Mérida: 1173-1198 (Anejos de Archivo Espanol de Arqueología 35).

Hernández Carretero, A. (2008) - Paleoambiente y Paleoeconomía en la Cuenca del Guadiana durante el Hierro I. In Ávila, J. J. (ed.) - Sidereum Ana I. El río Guadiana en época postorientalizante. Madrid (Anejos de AEspA XLVII): 135-147.

Hernandez Carretero, A. (2014) - Estudios de los restos polínicos de Castro Marim. In Arruda, A. M. (ed.) - Fenícios e púnicos por Terra e Mar (Actas do VI Congresso Internacional de Estudos Fenícios e Púnicos). Lisboa: 810-816.

Jehasse, J. - Jehasse, L. (1973) - La nécropole pré-romaine d'Aléria (1960-1968). Paris.

Lamboglia, N. (1951) - Ceramica presigillata a Ventimiglia, a Minorca e in Sicilia. ArchEspArq 24: 35-41.

Maia, M. A. - Maia, M. F. (1986)-Arqueologia da área mineira de Neves Corvo: trabalhos realizados no triénio 1982-84. Castro Verde.

Martín Ruiz, J. A. - Martín Ruiz, J. M. - García Carretero, J. R. (1995) - Las copas tipo cástulo del Cerro del Castillo (Fuengirola, Málaga). Una aportación al estudio de su distribución en el área del Estrecho. In Ripoll, E. - Ladero, M. F. (eds.) - Actas del II Congreso Internacional El Estrecho de Gibraltar. Madrid: 273-286.

Niveau de Villedary y Mariñas, A. Ma. (2003) - Las cerámicas gaditanas "tipo Kuass". Bases para el análisis de la bahía de Cádiz en época púnica. Madrid (Bibliotheca Archaeologica Hispana 21).

Oliveira, C. F. (2006) - A cerâmica manual do Castelo de Castro Marim (séculos IX a Ill a.n.e.). Lisboa 
(Dissertação de mestrado em Arqueologia apresentado à Faculdade de Letras da Universidade de Lisboa).

Oliveira, C. F. (2011) - O Castelo de Castro Marim durante a etapa final da Idade do Bronze. In Jimenez Ávila, J. (ed.) - Sidereum Ana II. El río Guadiana en el Bronce Final. Madrid: 345-362 (Anejos de Archivo Espanol de Arqueología XLVII).

Pellicer, M. - Escacena, J. L. - Bendala, M. (1983) - El Cerro Macareno. Madrid (Excavaciones Arqueológicas en España 124).

Picazo, M. (1977) - La cerámica ática de Ullastret. Barcelona.

Picazo, M. - Rouillard, P. (1976) - Les skyphos attiques à decor reservé et surpeint de Catalogne et du Languedoc. Mélanges de la Casa de Velázquez XII: 7-25.

Ponsich, M. (1969) - Les céramiques d'imitation: la campanienne de Kouass. Région d'ArcilaMaroc. Archivo Español de Arqueología 42: 56-80.

Presedo Velo, F. (1982) - La necrópolis de Baza. Madrid (Excavaciones Arqueológicas en España 119).

Py, M. - Adroher Auroux, A. M. - Sanchez, C. (2001) - Corpus des céramiques de l'Âge du Fer de Lattes (fouilles 1963-1999). Lattes (Lattara 14).

Queiroz, P. - Mateus, J. - Leeuwaarden, W. - Pereira, T. - Dise, D. (2006) - Castro Marim e o seu território imediato durante a Antiguidade. Paleo-etno-botânica. Relatório Final. Lisboa (Trabalhos do (IPA 95).

Rouillard, P. (1975) - Les coupes attiques à Figures Rouges du IV s. en Andalusie. Paris (Melanges de la Casa de Velazquez 11).

Rouillard, P. (1991) - Les grecs et la Péninsule Ibérique du VIII au IV siècle avant Jésus-Christ. Paris.

Rouillard, P. - Paixão, A. C. - Villanueva-Puig, M. C. - Durand, J. L. (1988-1989) - Les vases grecs d'Alcácer do Sal (Portugal). O Arqueólogo Português (série 4) 6-7: 43-108.

Ramón Torres, Joan (1995) - Las ánforas fenicio-púnicas del Mediterráneo central y occidental. Barcelona.

Rouillard, P. - Torre Castellano, I. - Sánchez Moreno, A. (2017) - Las cerámicas griegas áticas de figuras rojas de Zacatín (Granada, España). Archivo Español de Arqueología 90: 271-298.

Sánchez Fernández, C. (1981) - La cerámica ática de Ibiza en el Museo Arqueológico Nacional. Trabajos de Prehistoria 38: 281-315.

Sánchez Fernández, C. (1992) - Las copas tipo Cástulo en la Península Ibérica. Trabajos de Prehistoria 49: 327-333.

Sánchez, C. (1991) - El comercio de productos griegos en Andalucía Oriental en los siglos V y IV a.C. Estudio tipologico e iconográfico de la cerámica. Madrid.

Shefton, B. B. (1995) - Greek imports at the extremities of the Mediterranean, West and East: reflections on the case of Iberia in the fifth century BC. In Cunliffe, B. - Keay, S. (eds.) - Social complexity and the development of towns in Iberia. From the Copper Age to the Second century AD. Oxford: 127-156.

Silva, C. T. - Soares, J. - Beirão, C. M. - Dias, L. F. - Coelho-Soares, A. (1980-1981) - Escavações arqueológicas no Castelo de Alcácer do Sal (campanha de 1979). Setúbal Arqueológica 6-7: 149-218.

Soares, R. (2017) - A cerâmica grafitada e o seu contexto, entre a margem esquerda do Guadiana e a Serra de Aracena. Onoba 5: 171-193.

Sousa, E. (2009) - A cerâmica de tipo Kuass no Algarve. Lisboa.

Sousa, E. - Arruda, A. M. (2010) - A Gaditanização do Algarve. Mainake 32-2: 951-974.

Sousa, E. - Arruda, A. M. (no prelo) - Amphorae production and trade in western Iberia: an overwiew.

Sparkes, B. A. - Talcott, L. (1970) - The Athenian Agora, volume XII. Black and plain pottery of the 6 th, 5th and 4th centuries B.C. Princeton.

Trías, G. (1967-1968) - Cerámicas griegas de la Península Ibérica. Valencia.

Vandermersch, C. (1994) - Vins et amphores de Grande Grèce et de Sicile IVe-IIle s. avant J.C. Napoli. 
